\title{
RESPOSTA DE CULTIVARES DE MILHO AO NITROGÊNIO NO SISTEMA PLANTIO DIRETO \\ E SUA INFLUÊNCIA NA QUALIDADE DOS GRÃOS
}

\author{
AILDSON PEREIRA DUARTE \\ Engenheiro Agrônomo
}

Orientador: Prof. Dr. JORGE DE CASTRO KIEHL

Tese apresentada à Escola Superior de Agricultura "Luiz de Queiroz", Universidade de São Paulo, para obtenção do título de Doütor em Agronomia, Área de Concentração: Fitotecnia

PIRACICABA

Estado de São Paulo - Brasil

Janeiro - 2003 


\section{Dados I nternaci onai s de catal ogação na Publ i caçāo ( CI P) DI VI SÃO DE BI BLI OTECA E DOCUNENTAÇÃO - ESALQ/ USP}

\section{Duarte, Aildson Pereira}

Resposta de cultivares de milho ao nitrogênio no sistema plantio direto e sua influência na qualidade dos grãos / Aildson Pereira Duarte. - - Piracicaba, 2003.

$174 \mathrm{p}$.

Tese (doutorado) - Escola Superior de Agricultura Luiz de Queiroz, 2003. Bibliografia.

1. Fertilizantes nitrogenados 2. Grāos - qualidade 3. Milho 4. Plantio direto I. Título

CDD 633.15

\section{"Permitida a cópia total ou parcial deste documento, desde que citada a fonte -0 autor"}

\section{Oen de deposito junto CPG/ESALQ

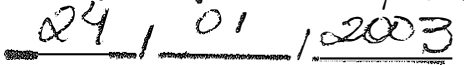


Aos meus pais

Antônio e Sebastiana

e à minha filha Leda,

DEDICO 


\section{AGRADECIMENTOS}

Ao professor Dr. Jorge de Castro Kiehl, do Departamento de Solos e Nutrição de Plantas da ESALQ/USP, pela orientação, incentivo e amizade;

Aos pesquisadores do Instituto Agronômico (IAC) Dr. Heitor Cantarella, Dr. José Guilherme de Freitas e Dr" Maria Elisa A. G. Zagatto Paterniani, pela participação no projeto de pesquisa que originou a presente tese e pelas sugestões para o seu aprimoramento;

Aos pesquisadores Dr. Stephen Carl Mason e Dr. David Jackson, da Universidade de Nebraska - Lincoln, pela disponibilização da infra-estrutura laboratorial e orientação nas determinações da qualidade dos grãos;

Ao pesquisador Nelson Bortoletto, do IAC/APTA Votuporanga, ao Engenheiro Agrônomo Paulo César Reco, do IAC/APTA Assis, e aos técnicos de apoio Wilson Strada, Erasmo Oliveira e Santos e Silvio Roberto do Nascimento, do IAC/APTA, pelo auxílio prestado na condução dos trabalhos no campo;

Aos pesquisadores Dr. Hélio do Prado e Dr. Orivaldo Brunini, do Instituto Agronômico, pela classificação dos solos e fornecimento de dados agrometeorológicos para a caracterização ambiental dos experimentos respectivamente;

Aos técnicos de laboratório Marcos Antônio Fabiano de Camargo e Claudinei de Lara, do Departamento de Solos e Nutrição de Plantas da ESALQ/USP, e Renata Presta, do Centro de Solos e Recursos Ambientais do IAC, pelas determinações de nitrogênio nos tecidos vegetais e amostras de solo; 
À técnica de apoio Fabiana Alves Cruz, da FUNDAG/IAC, pelo auxílio na digitação dos resultados e na elaboração das análises estatísticas;

Aos produtores rurais Sr. Edson Valmir Fadel e Sr. Waldir Donizete Rodrigues, cooperados COOPERMOTA, e Dr. José Carlos de Moura Camargo, pela disponibilização de suas propriedades rurais para o desenvolvimento dos experimentos;

Às empresas Agroceres, Dekalb, DowAgroSciences, Pioneer e Syngenta Seeds, às instituições IAC e Embrapa, pelo fornecimento de sementes de milho;

Ao $\mathrm{CNPq}$, pela concessão de bolsa para o desenvolvimento dos trabalhos no Brasil e nos EUA;

À FAPESP, pela concessão de auxílio à pesquisa que permitiu o financiamento parcial do projeto de pesquisa. 


\section{SUMÁRIO}

Página

RESUMO viii

SUMMARY $\mathrm{X}$

1 INTRODUÇÃO

2 REVISÃO DE LITERATURA 3

2.1 Fornecimento de Nitrogênio para a Cultura ............................................. 4

2.2 Absorção e Transolocação do Nitrogênio ............................................... 6

2.3 Interação Genótipos x Nitrogênio ......................................................... 9

2.4 Qualidade dos Grãos .................................................................... 14

3. MATERIAL E MÉTODOS _......................................................... 17

3.1 Locais e Caracterização Ambiental ....................................................... 17

3.1.1 Informações meteorológicos ........................................................... 17

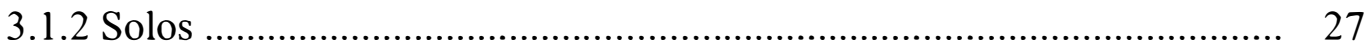

3.2 Delineamento Experimental e Procedimentos no Campo ......................... 31

3.2.1 Subprojeto Genótipos x Nitrogênio ………………………………..... 31

3.2.2 Subprojeto Parcelamento ................................................................ 34

3.2.3 Subprojeto Partição na Planta ............................................................. 35

3.3 Determinação do Nitrogênio no Solo e no Tecido Vegetal ..................... 40

3.4 A valiações da Qualidade Física dos Grãos ............................................ 40

3.5 Análise Estatística ........................................................................ 42

4 RESULTADOS E DISCUSSÃO _........................................................... 45

4.1 Nitrogênio no Solo ....................................................................... 45

4.2 Subprojeto Genótipos x Nitrogênio .................................................... 71 
4.3 Subprojeto Parcelamento ...................................................... 90

4.4 Subprojeto Partição ..................................................................... 102

4.4.1 Efeito da cultivar .................................................................. 106

4.4.2 Efeito do nitrogênio ................................................................ 128

4.4.3 Curva de acúmulo ................................................................. 135

4.5 Qualidade Física dos Grãos ...................................................... 142

4.6 Considerações Finais .............................................................. 145

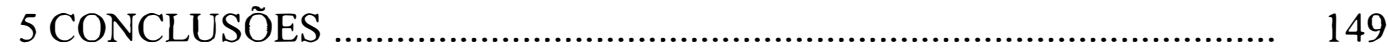

ANEXOS .......................................................................... 151

REFERÊNCIAS BIBLIOGRÁFICAS …............................................ 160 


\title{
RESPOSTA DE CULTIVARES DE MILHO
}

\section{AO NITROGËNIO NO SISTEMA PLANTIO DIRETO E SUA INFLUËNCIA NA QUALIDADE DOS GRÃOS}

\author{
Autor: AILDSON PEREIRA DUARTE \\ Orientador: Prof. Dr. JORGE DE CASTRO KIEHL
}

\section{RESUMO}

Foram instalados doze experimentos de campo nos municípios de Cândido Mota, Palmital, Votuporanga e Itapeva, situados no Estado de São Paulo, com a finalidade de avaliar o efeito da adubação nitrogenada no acúmulo, partição e eficiência de $\mathrm{N}$ na parte aérea das plantas, por ocasião do florescimento e maturação físiológica dos grãos, e no teor de $\mathrm{N}$ e qualidade física dos grãos, em diferentes cultivares de milho sob sistema plantio direto. Em dois experimentos o $\mathrm{N}$ foi aplicado na semeadura, nas doses 0 e $60 \mathrm{~kg}$ $\mathrm{ha}^{-1}$ de $\mathrm{N}$, e em cobertura, em doses que complementassem um total de 0,60, 120 e 180 $\mathrm{kg} \mathrm{ha}^{-1}$ de N. Em dez experimentos estudou-se a aplicação do $\mathrm{N}$ em quatro doses de cobertura ( 0 a $180 \mathrm{~kg} \mathrm{ha}^{-1}$ ) subdivididas em duas vezes. Dentre as treze cultivares estudadas, XL 212 destacou-se por apresentar baixa resposta da produtividade de grãos ao nitrogênio aplicado em cobertura, e IAC V1, BR 3123 e 8410, por apresentarem alta resposta. Os padrões de exigência de $\mathrm{N}$ durante os estádios iniciais de desenvolvimento variaram entre as cultivares: para a C 333B, o aumento na produção de grãos com a aplicação de $\mathrm{N}$ em cobertura não foi influenciado pela adubação de semeadura, enquanto para a BR 3123 a resposta foi maior quando o $\mathrm{N}$ foi aplicado na semeadura. As cultivares temperadas XL 212 e P 32R21 apresentaram os maiores teores de $\mathrm{N}$ na planta inteira no estádio de florescimento e/ou maturação de grãos, e as tropicais AG 1051 e BR 3123, as maiores partições de $\mathrm{N}$ no colmo na maturação e as maiores eficiências de uso do $\mathrm{N}$ na planta (massa por unidade de $\mathrm{N}$ ). As cultivares P 32R21 e BR 3123, muito responsi- 
vas ao $\mathrm{N}$, apresentaram os menores ciclos relativos após o florescimento, expressos como porcentagem do ciclo total até a maturação. $\mathrm{O}$ aumento da produtividade em função da adubação foi obtido com a redução da eficieiencia de uso do $\mathrm{N}$ na planta (unidade de massa na planta por unidade de $\mathrm{N}$ ) e do fertilizante ( $\mathrm{N}$ acumulado na planta / $\mathrm{N}$ aplicado) e, ao mesmo tempo, com o aumento da partição de $\mathrm{N}$ nos grãos ( $\mathrm{N}$ acumulado nos grãos/N na planta) e da eficiência de uso do $\mathrm{N}$ nos grãos. A partição de massa seca na fração espiga aumentou, e na fração colmo diminuiu com as doses de $\mathrm{N}$ nos experimentos em que a produtividade de grãos aumentou com a adubação nitrogenada. A proporção do $\mathrm{N}$ total acumulado na planta depois do florescimento variou de $19,6 \%$ a $39,8 \%$, dependendo da cultivar e dose de $\mathrm{N}$. A adubação nitrogenada melhorou a qualidade dos grãos, aumentando os teores de $\mathrm{N}$ e reduzindo a suscetibilidade ao quebramento, mesmo quando não houve aumento de produtividade. Predominou a forma N-nitrato no período em que a adubação aumentou o $\mathrm{N}$ inorgânico no solo. Em solo textura média não foram encontrados resíduos da adubação nitrogenada por ocasião do florescimento do milho, o contrário ocorrendo em solo argiloso quando a dose foi igual ou superior a $120 \mathrm{~kg} \mathrm{ha}^{-1}$. 


\section{RESPONSE OF MAIZE CULTIVARS TO NITROGEN UNDER NO TILL SYSTEM AND EFFECT ON GRAIN QUALITY}

Author: AILDSON PEREIRA DUARTE

Adviser: Prof. Dr. JORGE DE CASTRO KIEHL

\section{SUMMARY}

Twelve field trials were installed in the municipalities of Cândido Mota, Palmital, Votuporanga and Itapeva, in the State of São Paulo, Brazil, in order to evaluate the effects of nitrogen application on nitrogen efficiency, accumulation and partitioning in plant tops by the time of silking and kernel maturation, of different maize cultivars grown under direct seeding system; the effect on nitrogen content and physical quality of the grains was also evaluated. In two experiments nitrogen was applied at seeding at rates of 0 and $60 \mathrm{~kg} \mathrm{ha}^{-1}$ of $\mathrm{N}$ and side-dressed at rates such as to supply the total amounts of $0,60,120$ e $180 \mathrm{~kg} \mathrm{ha}^{-1}$ of $\mathrm{N}$. In ten experiments nitrogen was side-dressed at these same rates in two split applications. From the thirteen studied cultivars, XL 212 outstanded for showing low grain yield response to side-dressed nitrogen, and IAC Vl, BR 3123 and 8410, for presenting high response. Nitrogen requirement patterns along the early growth period varied among cultivars: for C 333B, the increase of grain yield as the result of side-dressing the nitrogen was not influenced by $\mathrm{N}$ applied at seeding, while BR 3123 showed higher response when this early application was made. 
Temperate cultivars XL 212 and P 32R21 showed the highest nitrogen content in the whole plant at silking and/or grain maturation stages, and tropicals AG 1051 and BR 3123 presented the highest proportions of $\mathrm{N}$ in the stalk at maturation and highest efficiency of $\mathrm{N}$ utilization (plant mass per unit of $\mathrm{N}$ ). The proportion of the period from silking to grain maturation, expressed as percent of the whole plant cycle, was smallest for P32R21 and BR 3123 cultivars, considered very responsive to nitrogen. The yield increase with nitrogen application resulted from a reduction of the efficiency of utilization of both plant $\mathrm{N}$ and fertilizer $\mathrm{N}$ ( $\mathrm{N}$ accumulated in the plant per unit of applied $\mathrm{N}$ ) and, at the same time, from the increase of $\mathrm{N}$ partitioning in the grains ( $\mathrm{N}$ accumulated in grains per unit of $\mathrm{N}$ in the plant) and of the efficiency of utilization of $\mathrm{N}$ in the grains (plant mass per unit of $\mathrm{N}$ ). In experiments showing grain yield increase with nitrogen application the partitioning of dry matter in the ears fraction increased, and in the stalk fraction decreased with the $\mathrm{N}$ rate. The proportion of $\mathrm{N}$ accumulated in the plant after silking varied from $19.6 \%$ to $39.8 \%$, depending on the cultivar and $\mathrm{N}$ rate. Nitrogen fertilization improved kernel quality for all cultivars, as it increased $\mathrm{N}$ content and hardness and decreased breakage susceptibility, even when no yield increase was observed. 


\section{INTRODUÇÃ}

A produtividade mundial de milho tem aumentado continuamente desde a introdução dos híbridos em meados da década 1931-40. Esses aumentos ocorreram devido ao maior potencial de colheita (melhoramento genético), à melhoria do manejo e práticas culturais, e às interações entre estes fatores (Russel, 1984). Os ganhos de produtividade de milho nos EUA nos últimos 30 anos foram proporcionais ao aumento do uso de fertilizantes minerais nitrogenados, associado à alta densidade de semeadura (Cardewel, 1982).

No Estado de São Paulo, o milho é a cultura anual que ocupa a maior área, aproximadamente 1 milhão e duzentos mil hectares, consumindo a maior quantidade de fertilizantes; nesse particular, é suplantanda apenas pela cana-de-açúcar. A baixa produtividade média do Estado, cerca de $3.500 \mathrm{~kg} \mathrm{ha}^{-1}$, não reflete o excelente nível tecnológico alcançado pelos produtores, já que as médias são obtidas em lavouras com diferentes finalidades da produção e sistemas de cultivo (Duarte \& Paterniani, 1998; Tsunechiro, 1997).

Ocorreram importantes mudanças nos sistemas de produção de sequeiro no Brasil na última década, ressaltando-se o aumento da área com uma segunda cultura no ano agrícola (safrinha) e a expansão do sistema de plantio direto. Esse fato alterou a produção e a permanência da biomassa vegetal no solo, especialmente com a presença da cobertura morta nas áreas de plantio direto.

Ressalte-se que os agricultores dispõem de mais de uma centena de cultivares de milho para a implantação das lavouras, com ampla diversidade genética. Aumentou a introdução de germoplasmas de clima temperado de porte baixo, geralmente de ciclo precoce e com maior índice de colheita, permitindo aumentar a densidade populacional e a flexibilidade nos esquemas de rotações e sucessões com outras culturas. Visando o 
aumento da produtividade, existe tendência de se reduzir o espaçamento e aumentar a população de plantas por área para a maioria dos novos híbridos, o que pode implicar em maior demanda por nutrientes pela cultura.

$\mathrm{O}$ nitrogênio, além de ser o nutriente fornecido em maior quantidade nas adubações, é o mais difícil de ser manejado e recomendado nas adubações. O aumento do custo dos adubos nitrogenados e a preocupação cada vez maior no exterior e no Brasil com os possíveis efeitos negativos do excesso de nitrato nos mananciais, são fatores que devem ser levados em consideração. Além disso, tem sido mostrado que alguns híbridos modernos apresentam padrões de acúmulo de nitrogênio diferentes dos cultivares tradicionais, sendo necessário o conhecimento dessas particularidades para que as recomendações de adubação nitrogenada para a cultura sejam racionais, econômicas e eficientes.

Recentemente, a qualidade dos grãos tornou-se um requisito para a comercialização da safra de milho no país, particularmente o valor nutricional e a integridade física. Cultivares com grãos duros (lisos) e semi-duros são preferidas porque considera-se que sejam menos susceptíveis ao trincamento e quebramento na colheita, secagem e transporte do que os grãos dentados. De maneira geral, predominam colhedoras e equipamentos de secagem e armazenagem inadequados para a manutenção da integridade física dos grãos. Porém, ainda não foram feitas avaliações objetivas da dureza dos grãos e da sua inter-relação com o quebramento, assim como da influência das práticas de manejo, como a adubação nitrogenada, na suscetibilidade ao quebramentos dos grãos.

Os objetivos do presente trabalho foram os seguintes:

1) Avaliar a resposta de diferentes cultivares de milho ao nitrogênio aplicado na base e em cobertura;

2) Verificar se as cultivares com grande proporção de germoplasma de clima temperado diferem das cultivares tropicais quanto ao acúmulo e partição do nitrogênio na planta, no florescimento e maturação fisiológica dos grãos, e à eficiência de uso do N;

3) Estudar os efeitos da adubação nitrogenada no conteúdo de nitrogênio e na qualidade física dos grãos;

4) Avaliar a disponibilidade do amônio e do nitrato em solos sob sistema plantio direto adubados com nitrogênio. 


\section{REVISÃO DE LITERATURA}

De maneira geral, o aumento no consumo de fertilizantes e a melhoria do germoplasma também têm sido apontadas como as principais razões para o aumento das colheitas nas regiões tropicais e subtropicais (Elings et al., 1997).

A utilização de fertilizantes nitrogenados aumentou substancialmente de 45 para $135 \mathrm{~kg} \mathrm{ha}^{-1}$ entre 1960 e 1972, e lentamente depois desta época, nos Estados de Illinois, Indiana, Iowa, Missouri e Ohio (Thompson, 1982 citado por Thompson 1986). Pesquisa sobre os sistemas de produção dos principais Estados produtores de milho dos EUA estimou um aumento do potencial de produção da lavouras no ano de 1979 em relação a época de 1930, igual a 47, 43, 23, 21 e 40\% devidos a adubação nitrogenada, melhoramento de plantas, uso dos herbicidas, população de plantas e outros, respectivamente (Cardewel, 1982). Mas, surgiram fatores negativos que não têm possibilitado a expressão desse potencial, tais como a diminuição da fertilidade dos solos devido às perdas por erosão. No caso do nitrogênio, houve perdas devido aos menores teores de matéria orgânica do solo e ao uso menos freqüente das práticas da adubação verde (sucessão com leguminosas forrageiras) e orgânica (estercos animais), que correspondem a $28 \%$ do aumento potencial da produção da atual adubação nitrogenada, ou seja, o aumento líquido da produção foi de apenas 19\%.

Assim, o aumento das colheitas não tem sido proporcional ao aumento da quantidade de fertilizantes utilizados. Esse fato, junto com o custo dos fertilizantes nitrogenados e a preocupação com a poluição do ambiente com nitrogênio, indicam a necessidade de desenvolver novos cultivares mais eficientes na conversão de fertilizantes nitrogenados em grãos. 


\subsection{Fornecimento de Nitrogênio para a Cultura}

Os solos, de maneira geral, contém quantidades relativamente elevadas de nitrogênio, porém, quase a totalidade das suas formas não são disponíveis às plantas. A maior parte do nitrogênio das camadas superficiais do solo é de natureza orgânica, correspondendo a mais de $90 \%$ do nitrogênio total (Jenkinson, 1968). A fração mineral representa uma porcentagem muito pequena do total, sendo constituída por amônio solúvel, amônio trocável, amônio fixado, nitrito e nitrato. Com exceção do amônio fixado, o nitrogênio mineral é solúvel em água e pode sofrer translocação por difusão ou ser arrastado pelo movimento da água no solo (Harmsen \& Kolenbrander, 1965).

Embora as plantas consigam utilizar algumas formas de nitrogênio presentes no solo (Dommergues \& Mangenot, 1970), o nitrogênio mineral, e mais especificamente o $\mathrm{N}$-amoniacal e o $\mathrm{N}$-nítrico, constituem a base da nutrição mineral da maioria das plantas (Crocomo \& Neptume, 1962). Os microrganismos do solo são um dos principais fatores na determinação do teor das formas de nitrogênio mineral, pois de sua atividade resulta a mineralização do nitrogênio orgânico, a imobilização do nitrogênio mineral e, ainda, sua volatilização.

O problema está, portanto, em se correlacionar a quantidade de nitrogênio que o solo é capaz de fornecer às culturas na época de seu desenvolvimento com a quantidade exigida por estas e com a que deve ser utilizada na adubação. Ou seja, é necessário ajustar as taxas de adubação nitrogenada às quantidades de $\mathrm{N}$ residual existentes no solo (Olson et al., 1976).

Geralmente, a eficiência de uso do $\mathrm{N}$ é determinada pela eficiência de absorção de $\mathrm{N}$ do solo e pela eficiência do uso do $\mathrm{N}$ pela planta para produzir matéria seca e grãos (Dwyer et al., 1995).

Feil et al. (1993) observou que a eficiência de utilização do $\mathrm{N}$ correspondeu de $48 \%$ a $60 \%$ do fertilizante $\left({ }^{15} \mathrm{~N}\right)$ aplicado, dependendo do cultivar. Embora esta diferença não tenha sido significativa, e os autores tenham concluído que estas não explicaram as largas diferenças dos genótipos quanto à absorção do N, os cultivares com maior ab- 
sorção de $\mathrm{N}$ foram os que tiveram os maiores índices de aproveitamento do $\mathrm{N}$ do fertilizante.

Em condições tropicais, a recuperação pela cultura do nitrogênio adicionado pelos fertilizantes é baixa devido ao grande potencial de perdas, sendo a lixiviação, a desnitrificação e a volatilização de amônia os mecanismos mais importantes (Osiname et al., 1983). Trabalhos realizados sob a coordenação da Agência Internacional de Energia Atômica - IAEA (1970) em vários países, inclusive no Brasil, sobre o manejo de nitrogênio na cultura do milho (Zea mays L.), utilizando-se ${ }^{15} \mathrm{~N}$, revelaram que a porcentagem de utilização do ${ }^{15} \mathrm{~N}$ do fertilizante pelas plantas (grãos + palha) variou de valores muito baixos $(20 \%)$ até valores altos $(>70 \%)$, com média de $40 \%$ para todos os países.

Ulloa et al. (1981) verificaram, em terra roxa estruturada, que a eficiência de recuperação do fertilizante nitrogenado aumenta com o desenvolvimento da cultura, tornando-se máxima (30\%) na fase de maturação.

Neptume (1977) obteve eficiência de utilização do fertilizante por uma cultura de milho em solo podzólico, variando de $40 \%$ a $58 \%$, sendo maior quando o nitrogênio foi aplicado aos 40 dias após a semeadura. Já, Reichardt et al. (1979) encontraram eficiência de utilização igual a $89 \%$ num solo relativamente pobre em nitrogênio. Esse alto valor possivelmente se deve ao fato de que houve distribuição uniforme da precipitação, favorecendo a recuperação do nitrogênio pelas plantas.

O balanço do nitrogênio no sistema solo planta-planta, num latossolo vermelhoescuro fase cerrado, indicou que dos $60 \mathrm{~kg} \mathrm{ha}^{-1}$ aplicados na forma de uréia, $56 \%$ foram absorvidos pela planta, $23 \%$ permaneceram no solo na camada $0-90 \mathrm{~cm}$ e $15 \%$ perderam-se do sistema (Coelho et al., 1991). A perda por lixiviação correspondeu a $4 \%$ do total do $\mathrm{N}$ aplicado, sendo o restante atribuído a outros processos não identificados.

Como o maior reservatório de $\mathrm{N}$ nos solos está ligado a cadeias carbônicas da matéria orgânica, o manejo dos resíduos vegetais pode alterar a disponibilidade do nitrogênio para as culturas.

Em Carambeí (PR), verificou-se em amostra da camada $0-7 \mathrm{~cm}$ do solo que o $\mathrm{N}$ mineral foi basicamente representado pelo $\mathrm{N}_{-} \mathrm{NO}_{3}{ }^{-}$, porém, após 10 semanas de incubação o teor encontrado em amostra do solo sob plantio direto foi 2,2 vezes superior ao 
observado em amostra de área sob preparo convencional (Sá, 1995a). Segundo o autor, isto indica maior atividade dos microrganismos nitrificadores, pois nessa camada do perfil as condições ambientais para a atividade desses agentes são mais favoráveis no plantio direto do que no preparo convencional. Abaixo de $30 \mathrm{~cm}$, tanto no plantio direto quanto no preparo convencional predominou a forma $\mathrm{NH}_{4}{ }^{+}$, apesar de se ter observado a presença da forma $\mathrm{NO}_{3}{ }^{-}$na profundidade de $21-60 \mathrm{~cm}$. Neste caso, a elevação da acidez, a redução do teor de carbono e a menor disponibilidade de nutrientes foram considerados os fatores que poderiam ter limitado a atividade dos nitrificadores, porém, sem impedir a amonificação.

$\mathrm{Na}$ fase inicial do plantio direto observa-se a necessidade de aplicação de maiores quantidades de $\mathrm{N}$ devido à intensificação do processo de imobilização no solo. Essa intensificação se deve ao aumento da atividade microbiana como resposta à maior oferta de carbono no sistema. Após o quarto ano de implantação do sistema, parece ocorrer o início do restabelecimento do equilíbrio das transformações que ocorrem no solo, à medida em que ocorre a reposição dos resíduos culturais, proporcionando acúmulo na camada 0-2,5 cm (Sá, 1993). Observou-se, após 9 a 12 anos de plantio direto, maior liberação de N ao sistema com menor resposta à adubação nitrogenada (Sá, 1995b).

Com relação ao parcelamento da adubação nitrogenada, os trabalhos mais recentes têm recomendado o emprego de $30 \mathrm{~kg} \mathrm{ha}^{-1}$ no momento da semeadura e o restante em cobertura (Cantarella \& Duarte, 1996; Sá, 1995b). Sá (1995b) observou que a dose 60 $\mathrm{kg} \mathrm{ha}^{-1}$ causou o aparecimento de sintomas de fitotoxicidade nas plântulas.

\subsection{Absorção e Translocação do Nitrogênio}

O nitrogếnio é um dos macronutrientes de importância fundamental nos componentes orgânicos das plantas. A parte contida nos aminoácidos, proteínas, nucleotídeos, coezimas, pigmentos clorofilados, hormônios e outros compostos nitrogenados constitui aproximadamente $3 \%$ da massa de matéria seca do vegetal. Ao utilizarem o $\mathrm{NO}_{3}^{-}$como fonte de nitrogênio, as plantas superiores e os microrganismos precisam reduzí-lo ao 
nível de valência do $\mathrm{NH}_{3}$, sendo uma das etapas da redução realizada pela enzima redutase do nitrato, que é uma flavoproteína (Epstein, 1975).

No que se refere à marcha de absorção de $\mathrm{N}$ pela planta de milho, um dos primeiros trabalhos foi realizado por Sayre (1948), que concluiu existir maior acúmulo de N nos tecidos verdes, havendo, posteriormente, intensa translocação para os grãos. Em nosso meio, Andrade et al. (1975), estudando a marcha de absorção de nutrientes em cinco cultivares de milho, verificaram que a época de máxima acumulação está entre 89 e 100 dias a partir da germinação. Ulloa (1981) encontrou maior acumulação de nitrogênio total e do nitrogênio proveniente do fertilizante aos 60 dias de idade nas partes vegetativas, e entre os 120 e 150 dias de idade nos grãos, enquanto que para a planta toda obteve maior acúmulo aos 120 dias da germinação.

A literatura indica que a eficiência com que a planta de milho utiliza o fertilizante nitrogenado é afetada por muitos parâmetros, incluindo a morfologia e extensão das raízes, os mecanismos bioquímicos ou físiológicos de regulação da absorção de $\mathrm{NO}_{3}{ }^{-}$, e a redistribuição e transporte de $\mathrm{N}$ para diferentes partes da planta ( Neyra et al., 1988).

Como o índice de colheita e a produção de biomassa têm aumentado simultaneamente nos últimos anos (Tollenaar, 1989), Feil et al. (1992) sugeriram que a ausência de correlação inversa entre a produtividade e o teor de $\mathrm{N}$ nos grãos indica a presença de uma grande biomassa de raízes da planta que possibilita a melhor exploração do volume do solo para a extração de nutrientes (aumento do acúmulo de $\mathrm{N}$ na planta e nos grãos).

Porém, Feil et al. (1990) concluíram que as diferenças na morfologia das raízes não podem explicar completamente os contrastes na utilização de $\mathrm{N}$ pelos cultivares, devido ao fato de outras características varietais, como a atividade de redutase do nitrato, também poderem influir na sua absorção. Além disso, deve-se considerar que a maior capacidade de aquisição do $\mathrm{N}$ do solo é apenas uma possibilidade de melhorar a eficiência de utilização do nitrogênio pelos genótipos. Uma redistribuição mais eficiente, devido à alta atividade das proteases das folhas (Reed. et al., 1980), deveria levar a uma melhor utilização do nitrogênio já assimilado.

A respeito da translocação de $\mathrm{N}$ em baixos níveis de fertilizantes, Pollmer et al. (1979) sugeriram que a baixa absorção de $\mathrm{N}$ depois do florescimento é um pré-requisito 
para encontrar alta translocação de N. Similarmente, Friedrich \& Schrader (1979) encontraram evidência de elevada translocação de $\mathrm{N}$ em experimentos onde esse nutriente foi mantido em baixo nível.

Plantas muito prolíferas demonstraram grande remobilização de $\mathrm{N}$ dos tecidos vegetativos para os grãos (Pan et al., 1984). No entanto, também mostraram menor capacidade de absorver $\mathrm{N}$ durante o desenvolvimento da espiga, particularmente se a fonte for nitrato. Competição entre grãos e raízes por fotoassimilados pode reduzir a absorção de $\mathrm{N}$ após a antese e limitar a produção de híbridos prolíferos (Pan et al., 1984). Um aumento da massa seca das espigas, associado à perda líquida da massa das raízes, sugere que o enchimento dos grãos do milho tem maior prioridade do que o funcionamento das raízes (Pan et al., 1995). Como o tamanho do dreno reprodutivo tem se mostrado inversamente relacionado com a quantidade de $\mathrm{C}$ translocado para o sistema radicular (Palmer et al., 1973) e colmos (Campbell, 1964), a demanda do dreno pode ter restringido a absorção, translocação e ou redução do nitrato em amônio durante o desenvolvimento de múltiplas espigas.

O desenvolvimento de genótipos que exibem alta eficiência sob uma gama de níveis de fertilidade de $\mathrm{N}$ requer melhoria dos processos envolvendo a remobilização do $\mathrm{N}$ previamente armazenado e a absorção e assimilação durante o desenvolvimento das espigas. Mais recentemente, foram desenvolvidos híbridos prolíferos produtivos e apresentando elevada eficiência de uso do N; os aumentos da colheita foram acompanhados por suficiente aumento da capacidade fotossintética e capacidade de absorção de $\mathrm{N}$ após a antese (Moll et al., 1994).

Alta quantidade de $\mathrm{N}$ contribui para a manutenção da integridade fotossintética, uma vez que $50 \%$ a $70 \%$ do total do $\mathrm{N}$ das folhas de milho estão associados diretamente aos cloroplastos (Hageman, 1986). Uma forte correlação tem sido demonstrada entre a taxa fotossintética líquida e o teor de $\mathrm{N}$ ou proteína da folha, com a fotossíntese aumentando linearmente até um valor crítico de $\mathrm{N}$ na folha a partir do qual permanece constante (Dwyer et al., 1995). Esse fato sugere que o teor de $\mathrm{N}$ na folha pode ser um critério para estimar a capacidade fotossintética numa dada condição ambiental. 
Dwyer et al. (1995) verificaram que as plantas de todos os híbridos estudados foram capazes de manter a fotossíntese com baixos teores de $\mathrm{N}$ na folha nos últimos estádios de crescimento. Os autores comentaram que a concentração de $\mathrm{N}$ não é o único fator que altera a taxa fotossintética durante o enchimento de grãos; a permanência da área verde da folha contribui para a manutenção da sua taxa fotossintética.

\subsection{Interação Genótipos x Nitrogênio}

Os híbridos novos e mais produtivos são mais responsivos e exigentes quanto ao suprimento de nitrogênio? Carlone \& Russel (1987) estudaram a eficiência da densidade de semeadura e dos níveis de nitrogênio de cultivares de milho de diferentes épocas de melhoramento, no Estado de Iowa, sobre a produtividade. Não ficou claro que o melhoramento nas épocas sucessivas tem produzido híbridos que proporcionam maiores respostas ao nível de $\mathrm{N}$ no solo; geralmente os híbridos com altas produções em níveis elevados de $\mathrm{N}$ também proporcionaram altas produções com baixos níveis de $\mathrm{N}$. A maior produção dos novos híbridos foi devido principalmente à sua habilidade em produzir sob altas densidades de plantas.

Corroborando com esse fato, Duvick (1984) estudou importantes híbridos empregados no Estado de Iowa no período de 1934 a 1978, verificando que os novos híbridos foram produtivos sob altas densidades de plantas (folhas mais eretas) e altos níveis de fertilidade do solo, e foram também consistentemente superiores aos antigos em condições ambientais de baixa produção (seca e deficiência de $\mathrm{N}$ ).

Não existem estudos específicos sobre a evolução dos híbridos empregados no Brasil. A literatura a respeito do cultivo e melhoramento do milho é originada, principalmente, de áreas temperadas, particularmente dos Estados Unidos da América do Norte. É necessário entender as características do ambiente tropical para a produção de milho, especialmente os fatores adversos, que são mais numerosos e de maior magnitude do que nas áreas temperadas. As condições tropicais não são uniformes, existindo grande variação entre as diferentes áreas (Paterniani, 1990). 
Segundo Moro et al. (1981), as populações de milho de clima tropical caracterizam-se por apresentarem plantas com folhagem abundante, porte baixo e ciclo longo. Esse tipo de planta se adapta bem ao cultivo tradicionalmente utilizado nas regiões tropicais, que emprega baixa densidade populacional. Os programas oficiais e privados de melhoramento de milho no Brasil e em outros países de clima tropical têm dado grande ênfase à introdução de novos germoplasmas para a obtenção de cultivares de porte baixo e de ciclo precoce a intermediário, resultando no aumento do índice de colheita (Moro et al., 1981; Dowswell et al., 1996).

Plantas de menor porte permitem o uso de maior densidade populacional e facilitam a colheita mecânica devido ao menor risco de acamamento. Por sua vez, um ciclo mais curto possibilita rotações, sucessões e/ou consorciações com outras culturas, e pode ser uma garantia para o cultivo do milho em regiões onde os períodos chuvosos são limitados (Moro et al. 1981).

Feil et al. (1992) verificaram, durante período seco com irrigação suplementar na Tailândia, que cultivares representativos do germoplasma tropical tinham menor teor de nutrientes na parte aérea do que materiais temperados europeus, porém, maior produção de massa seca, o que explica a maior absorção. Devido ao maior índice de colheita dos materiais europeus e aos teores similares de nutrientes nos grãos, a extração dos nutrientes na colheita foi similar entre os genótipos. Thiraporn et al. (1983) encontraram baixa acumulação de $\mathrm{N}$ e $\mathrm{P}$ em plantas adultas de híbridos europeus, porém, a época era chuvosa e as condições mais desfavoráveis aos referidos materiais.

Devido ao ciclo mais curto do material de clima temperado, em relação ao tropical, poder-se-ia esperar que o tempo de absorção de nutrientes fosse mais restrito (Thiraporn et al., 1983; Feil et al., 1992). Porém, Feil et al. (1992) verificaram que o material tropical absorveu cerca de $43 \%, 34 \%$ e $85 \%$ do $\mathrm{N}$, do P e do $\mathrm{K}$, respectivamente, antes do florescimento, contra os 39\%, 26\% e 76\% do material temperado. Quando se analisou a assimilação diária de $\mathrm{N}$, verificou-se que o material europeu foi inferior ao tropical antes e depois da polinização. Como o material europeu obtém maior massa seca da parte aérea após a polinização, a absorção de nutrientes é muito maior após este estádio, alongando o tempo de absorção. 
Osaki (1995a) conduziu experimentos no México e no Japão para identificar diferenças na produtividade do milho em regiões temperadas e tropicais, destacando-se os seguintes resultados:

1) A quantidade de massa seca e de nitrogênio acumulado no milho de região tropical não aumentou após os primeiros estádios de desenvolvimento dos grãos, apesar da quantidade adequada do nitrogênio aplicado. No milho de clima temperado, contudo, os valores continuaram a aumentar durante o desenvolvimento dos grãos.

2) As quantidades de massa seca e de nitrogênio nas folhas e colmos do milho de clima tropical decresceram acentuadamente depois do florescimento, apesar da quantidade adequada de nitrogênio, independentemente das condições de crescimento. Especialmente a senescência das folhas do milho tropical tornou-se rápida exatamente depois do florescimento. Foi impossível prevenir a senescência das folhas no florescimento através da suplementação de nitrogênio, e da alteração da distribuição de luz na parte inferior no dossel, apesar de essa alteração ter estimulado a absorção de carbono e nitrogênio. Daí ter-se considerado que a senescência das folhas do milho tropical é regulada por um processo autônomo (não associado à arquitetura da planta).

3) Quando as folhas inferiores receberam uma quantidade suficiente de luz, o milho tropical pôde absorver nitrogênio depois do florescimento, e o decréscimo da taxa de clorofila nas folhas tornou um pouco menos pronunciado, indicando que aumentou a atividade das folhas inferiores e das raízes (a atividade fotossintética é limitante depois da polinização). Ou seja, a baixa produção do milho tropical foi atribuída mais à rápida senescência das folhas depois do florescimento do que à arquitetura das folhas.

4) Verificou-se que a maior quantidade do nitrogênio dos grãos do milho tropical foi retranslocada das folhas e do colmo (cerca de $60 \%$ do nitrogênio dos grãos foram derivados da parte acumulada nas folhas e colmos antes do florescimento), e que a maior quantidade de nitrogênio dos grãos do milho temperado foi absorvida pelas raizes durante a maturação.

Segundo Osaki (1995a), no milho tropical o nitrogênio das folhas é translocado rapidamente, a atividade fotossintética decresce com a redução do teor de $\mathrm{N}$ nas folhas, decresce a translocação de fotoassimilados para as raízes quando a atividade fotossinté- 
tica das folhas diminui, limitando a atividade das raízes, e finalmente, o nitrogênio não é absorvido. Cessando a absorção de $\mathrm{N}$, aumenta a decomposição dos compostos nitrogenados da folha e a taxa fotossintética reduz-se drasticamente. No milho de clima temperado permanecem altos teores de $\mathrm{N}$ e clorofila após a metade do estádio de senescência, fazendo com que os fotoassimilados continuem sendo translocados para as raízes e o nitrogênio possa ser absorvido.

Os valores relatados por Osaki (1995a) são diferentes daqueles obtidos por Ulloa (1981a,b) em Terra Roxa Estruturada, em Piracicaba (SP), o qual empregou dois híbridos com características tropicais; esse autor verificou que $45 \%$ do ${ }^{15} \mathrm{~N}$ proveniente do fertilizante foram translocados dos órgãos vegetativos para os grãos até a maturação fisiológica, e o restante foi absorvido do solo após o florescimento.

O milho tropical cultivado em terras baixas no período do verão apresentou menores índices de colheita de matéria seca e de nitrogênio e maior quantidade de nitrogênio acumulado na planta na colheita, em comparação com o temperado (Osaki, 1995b). Para os autores, quanto maior a quantidade de nitrogênio acumulada na planta no momento da colheita, maior o índice de eficiência do uso do nitrogênio em termos de matéria seca da planta (carbono). Assim, em solos com baixo nível de fertilidade, o milho tropical utilizou o $\mathrm{N}$ mais eficientemente para a produção de matéria seca (menor potencial de produção) e, em solos com alto nível de fertilidade, o milho temperado foi o mais eficiente.

Simulações realizadas com material de origem tropical e subtropical, realizadas no México, indicaram que em altos níveis de produção o enchimento dos grãos de milho está limitado pelo dreno, e que o aumento do número de grãos por metro quadrado, através de maior tamanho da espigas primárias, prolificidade ou densidade de plantas, conduzirá a melhores rendimentos de grãos (Elings et al., 1997). A fonte metabólica limitou o processo de enchimento dos grãos apenas sob baixa disponibilidade de $\mathrm{N}$ no solo, sendo pouco provável que o aumento da capacidade de dreno resultaria em maiores produções. Uma linha de trabalho possível no melhoramento vegetal é a seleção de materiais que extraem mais nitrogênio do solo, presumindo-se que isso resulte alta concentração de $\mathrm{N}$ nas folhas. $\mathrm{O}$ estudo de simulação sugeriu um aumento de $1,2 \%$ na produção 
de grãos para cada aumento de $5 \%$ de $\mathrm{N}$ nas folhas. Embora todos os cultivares tivessem acumulado uma quantidade de $15 \mathrm{~kg} \mathrm{ha}^{-1}$ nas folhas cerca de 4 a 5 semanas após a semeadura em todos os experimentos, a quantidade máxima de $\mathrm{N}$ no tecido de folha verde sob condições de baixo teor de $\mathrm{N}$ no solo variou de $17,4 \mathrm{a} 25,4 \mathrm{~kg} \mathrm{ha}^{-1}$.

Simulações de aumento da densidade de milho tropical e subtropical resultaram em aumentos superiores a 50\% na produção de grãos (Elings et al., 1997). No entanto, os autores mencionaram que isso requer cultivares tolerantes à alta densidade de plantas (quebramento + acamamento e esterilidade), assim como alta disponibilidade de $\mathrm{N}$ no solo para sustentar um mínimo de crescimento da planta durante o "estádio de dreno".

Como já citado, os genótipos empregados predominantemente nas áreas de clima tropical diferem muito daqueles cultivados sob clima temperado. Magnavaca et al., citado por Paterniani (1990), mostrou, em solução nutritiva, que linhagens brasileiras são mais tolerantes ao $\mathrm{Al}$ do que linhagens americanas em relação ao comprimento de raízes seminal e adventícias. Como a deficiência de nitrogênio nos trópicos é muito freqüente (Machado \& Paterniani, 1988) e a toxidez de alumínio é problema na maioria das áreas tropicais, a deficiência de nitrogênio na cultura do milho pode ser acentuada pelo confinamento do sistema radicular na camada superficial do solo devido à toxidez de alumínio subsuperficial.

Há claras indicações de que existam diferenças na utilização do $\mathrm{N}$ entre os genótipos de milho, não apenas em termos de resposta à fertilização nitrogenada, mas também em eficiência na absorção, acumulação e utilização do $\mathrm{N}$ absorvido (Beauchamp et al., 1976; Chevallier \& Schrader, 1977; Moll \& Kamprath, 1977; Pollmer et al., 1979; Reed et al., 1980).

Lang et al. (1956) avaliaram nove híbridos simples semeados em seis densidades de plantas e tratados com três níveis de nitrogênio, verificando haver interação significativa entre cultivares, densidade e nitrogênio, para a produção. Nos trabalhos de Lang et al. (1956) e Carlone \& Russel (1987), a predição de resposta do milho ao tratamento de $\mathrm{N}$ não foi válida sem o conhecimento do híbrido e da densidade de plantas.

Balko \& Russel (1980) verificaram que a máxima produção dos cruzamentos simples nos campos de sementes pode ser obtida com menor nível de $\mathrm{N}$ do que o requerido 
normalmente para a produção de grãos, mas o nível ótimo de $\mathrm{N}$ pode variar com a linhagem.

Albus \& Moraghan (1995) não encontraram interação significativa em vários parâmetros agronômicos para fertilização nitrogenada em três híbridos precoces de milho em experimento irrigado no Dakota do Norte, EUA, mas ocorreram diferenças entre os genótipos quanto à eficiência de uso do $\mathrm{N}$ ( $\mathrm{N}$ acumulado nos grãos/ $\mathrm{N}$ total na parte aérea), com valores variando de 61 a $68 \%$.

\subsection{Qualidade dos Grãos}

Alguns estudos têm apontado correlação negativa entre a produtividade e o teor de $\mathrm{N}$ nos grãos (Dudley et al., 1977), enquanto outros não têm encontrado essa correlação (Feil et al., 1992; Kauffmann \& Dudley, 1979; Feil et al.; 1993).

Tsai et al. (1983) reportou que existe correlação positiva entre a produção e o teor de proteínas nos grãos para um híbrido individual. No entanto, para um conjunto de híbridos, a produção de grãos é geralmente correlacionada negativamente com o teor de $\mathrm{N}$ nos grãos (Dudley et al., 1977; Tsai et al., 1992). Tsai et al. (1983) consideraram que essa relação inversa foi devida ao baixo dreno de $\mathrm{N}$ nos híbridos com baixa produção, que tornaram saturados em níveis relativamente baixos de fertilização nitrogenada.

$\mathrm{O}$ teor de $\mathrm{N}$ nos grãos geralmente aumenta com o aumento da disponibilidade desse elemento no solo (Thiraporn et al., 1992). No entanto, observa-se ocasionalmente que a adição de pequena quantidade de fertilizante nitrogenado causa ligeira redução no teor nos grãos (Cerrato \& Blackmer, 1990). Isso é explicado pelo efeito diluição do N nos grãos devido ao aumento no teor de carbohidratos induzido pelo fertilizante.

Avalia-se a qualidade física dos grãos pela dureza (densidade), suscetibilidade ao quebramento (fragilidade) e estresse dos grãos ao esmagamento. Os exportadores preferem lotes secos ao ar natural contendo grãos uniformemente grandes e sem quebramento, considerando que o quebramento de grãos leva ao aumento da proporção de grãos 
quebrados e impurezas, que é o principal fator de qualidade no mercado internacional (Hill, 1981).

Grãos maiores e uniformes são desejados para a moagem a seco (Paulsen \& Hill, 1985), moagem úmida (Watson, 1987), cocção alcalina (Shumway et al., 1992) e ração animal quando processada por prensagem e esmagamento. Na moagem a seco prefere-se grão secos ao ar natural uniformemente grandes e sem quebramento ( Paulsen \& Hill, 1985). Para a extração de amido pela moagem úmida, o milho deve ter baixo índice de grãos quebrados e impurezas e baixa suscetibilidade ao quebramento para manter alto rendimento de amido (Watson, 1987).

Tem sido mostrado que o peso dos grãos aumenta com a aplicação de nitrogênio (Bauer \& Carter, 1986; Kniep \& Mason, 1989; Cromwell et al., 1983; Rendig \& Broadbent, 1975) e decresce com o aumento da população de plantas (Bauer \& Carter, 1986; Vyn \& Moes, 1988; Vyn \& Tollenaar, 1998).

O peso dos grãos é freqüentemente associado com outros parâmetros de qualidade tais como densidade dos grãos ( Kniep \& Mason, 1989; Paulsen et al., 1983), suscetibilidade ao quebramento (Kniep \& Mason, 1989; Johnson \& Russell, 1982) e concentração de proteína (Manokarkumar et al., 1978; Oikeh et al., 1998; Arnold et al., 1977). Grãos menores, mais densos e com aumento da proporção de vítreo endosperma são mais resistentes aos danos mecânicos (Johnson \& Russell, 1982; LeFord \& Russell, 1982; Vyn \& Moes, 1988). Grãos maiores são aparentemente mais suscetíveis ao quebramento do que os menores (Thompson \& Foster, 1963; Vyn \& Moes, 1988; Miller et al., 1981; Leford \& Russell, 1985; Johnson \& Russell, 1982). No entanto, Vyn \& Tollenaar (1998) encontraram maior quebramento de grãos em híbridos produzindo grãos pequenos.

A aplicação de nitrogênio aumenta a qualidade física dos grãos. Bauer \& Carter (1986) estudaram a suscetibilidade ao quebramento e a densidade dos grãos em nove híbridos de milho com diferentes classificação de maturidade e práticas de produção. Eles encontraram que a adubação nitrogenada decresceu a suscetibilidade ao quebramento. Em estudo similar, Kniep \& Mason (1989) confirmaram que a suscetibilidade ao quebramento aumentou com irrigação e decresceu com a aplicação de nitrogênio. Eles 
também encontram que a suscetibilidade ao quebramento aumentou com o aumento da colheita dos grãos. Bauer \& Carter (1986) reportaram ausência de correlação da densidade dos grãos com a suscetibilidade ao quebramento e a produtividade, enquanto Kniep \& Mason (1989) encontraram correlação significativa. O aumento das colheitas com a irrigação ajuda a explicar como a irrigação pode decrescer a qualidade física dos grãos.

Diferenças na suscetibilidade ao quebramento devido ao nitrogênio do solo são relacionadas às diferenças na assimilação e acúmulo de zeína durante o enchimento dos grãos (Tsai et al., 1983). Tsai et al. (1992) reportaram que o aumento da produção de proteína com a aplicação de nitrogênio foi acompanhada pelo aumento na quantidade de zeína presente no endosperma, produzindo grãos duros, menos quebradiços e mais translúcidos. Quando a concentração de proteína aumenta nos grãos, zeína aumenta sua proporção na proteína (Frey et al., 1949; Tsai et al., 1992).

Como a zeína contém baixa quantidade dos aminoácidos essenciais mais limitantes, lisina e triptofano, o aumento da colheita de grãos influencia o balanço de aminoácidos pela redução da concentração de lisina e triptofano e conseqüente redução do valor biológico da proteína. No entanto, isto pode ser compensado, em alguns casos, com o aumento do tamanho do germe com a aplicação de nitrogênio, que tem melhor balanço de aminoácidos do que o endosperma (Bhatia \& Rabson, 1987.) 


\section{MATERIAL E MÉTODOS}

Desenvolveram-se três subprojetos no sistema plantio direto: - "Resposta de Genótipos de Milho ao Nitrogênio" (Subprojeto Genótipos x Nitrogênio), "Resposta de Genótipos de Milho ao Parcelamento e Doses de N" (Subprojeto Parcelamento) e "Acúmulo e Partição do Nitrogênio em Genótipos de Milho" (Subprojeto Partição na Planta), totalizando 12 experimentos.

\subsection{Locais e Caracterização Ambiental}

Foram conduzidos experimentos nos municípios de Cândido Mota (S22\%47' W $\left.50^{\circ} 24^{\prime}\right)$, Votuporanga ( $\mathrm{S} 20^{\circ} 25^{\prime}$ W $\left.50^{\circ} 04^{\prime}\right)$, e, apenas no subprojeto Genótipo x Nitrogênio, também em Itapeva (S23⒌' W48 ${ }^{\circ} 4^{\prime}$ ') (Tabela 1). No segundo e terceiros anos, a área de Cândido Mota foi substituída por outra no município vizinho de Palmital (S22 $48^{\prime}$ 'W50 $0^{\circ} 6^{\prime}$ ). Esses locais representam as regiões noroeste e sudoeste do Estado de São Paulo (Figura 1), que são importantes produtoras de milho e têm clima e solos distintos.

\subsubsection{Informações agrometeorológicas}

Utilizaram-se informações coletadas em estações agrometeorológicos do Instituto Agronômico (IAC) em áreas adjacentes (Votuporanga) ou distantes cerca de $5 \mathrm{~km}$ dos experimentos (Itapeva, Cândido Mota e Palmital). Foram construídos balanços hídricos decendiais pelo método de Thornthwaite e Mather (1995) modificado por Camargo e Camargo (1983), corrigindo a temperatura do ar para a estimativa da evapotranspiração potencial de acordo com Camargo e Camargo (2000) (Figuras 2 a 8). 
Tabela 1. Principais características dos locais e períodos em que foram desenvolvidos os experimentos dos subprojetos Genótipos x Nitrogênio ( $\mathrm{N}$ x G), Parcelamento e Partição.

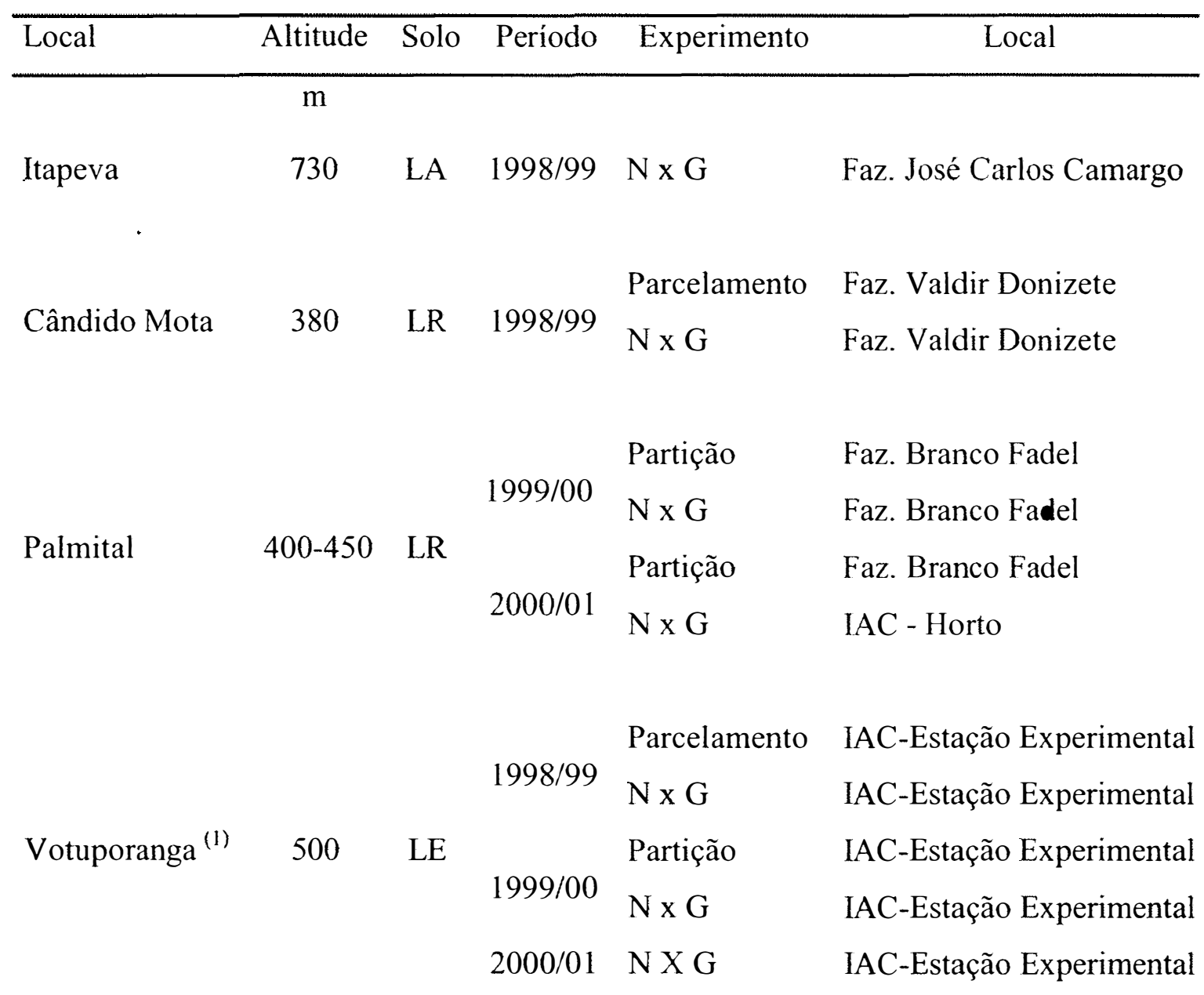

(1) Os experimentos desenvolvidos em Votuporanga em 1998/99 foram irrigados. 


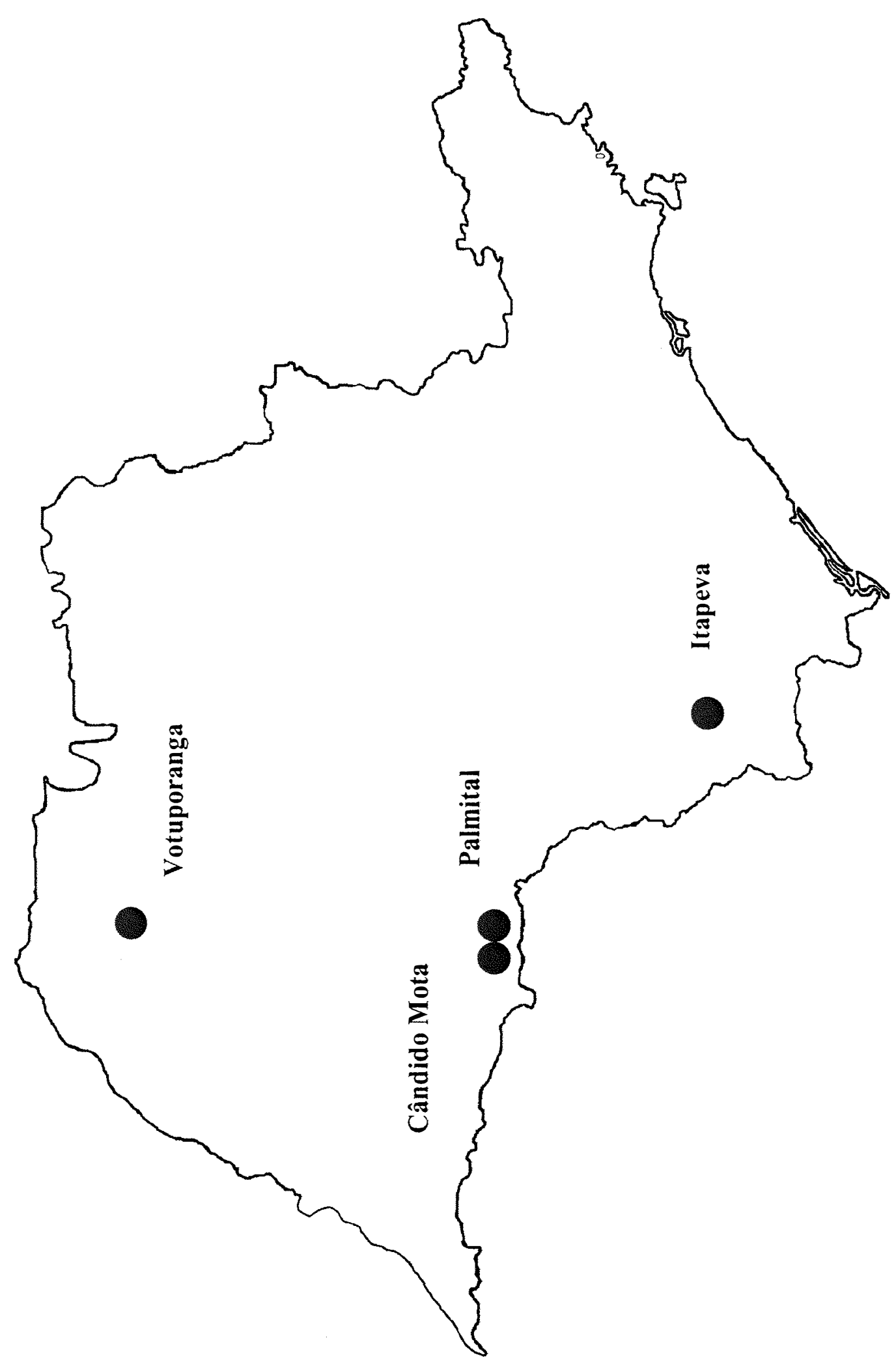

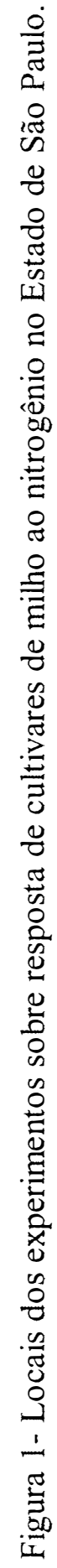



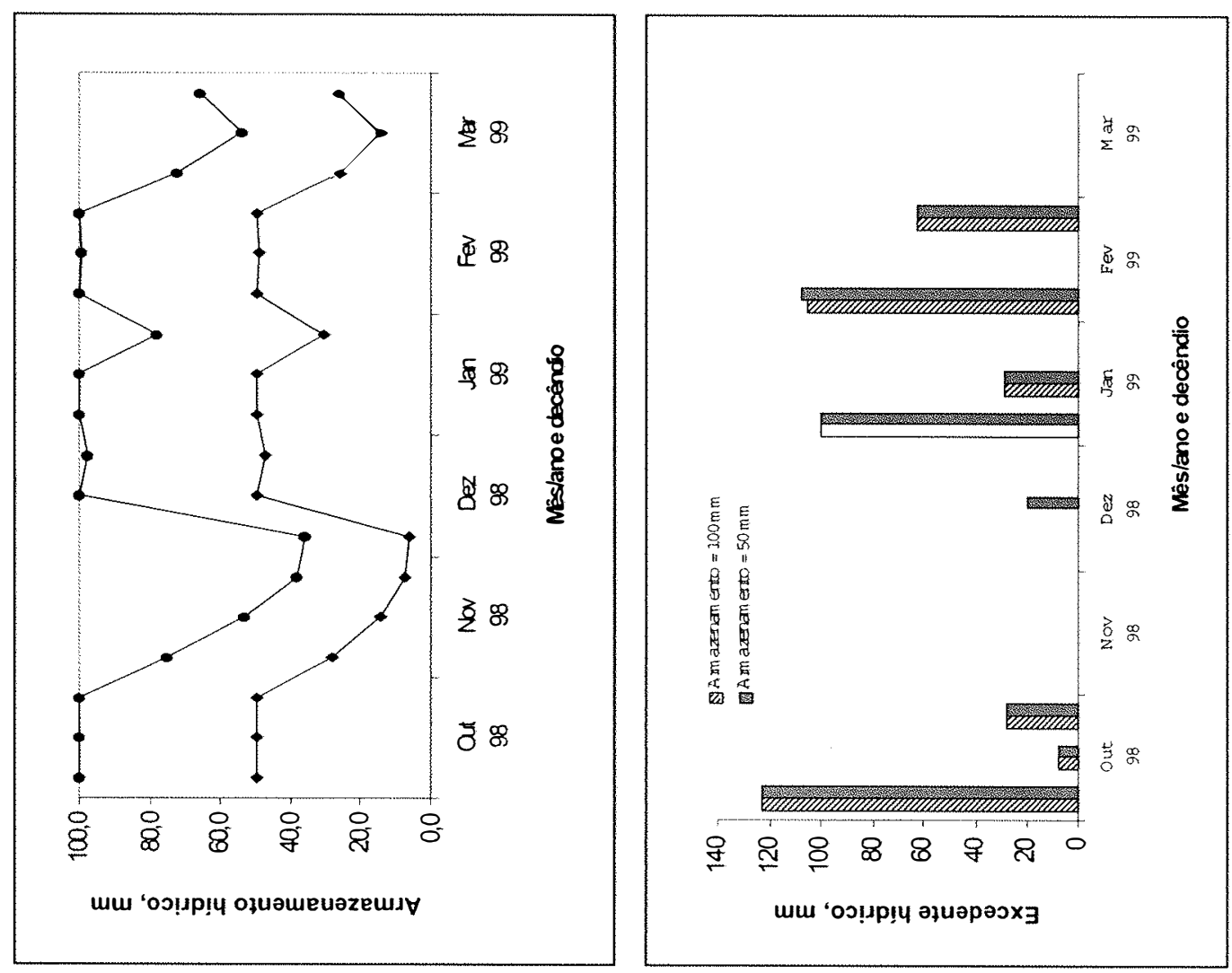

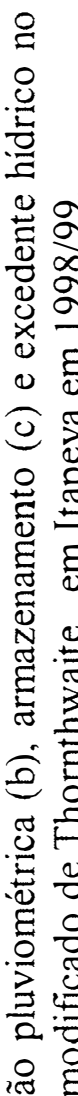

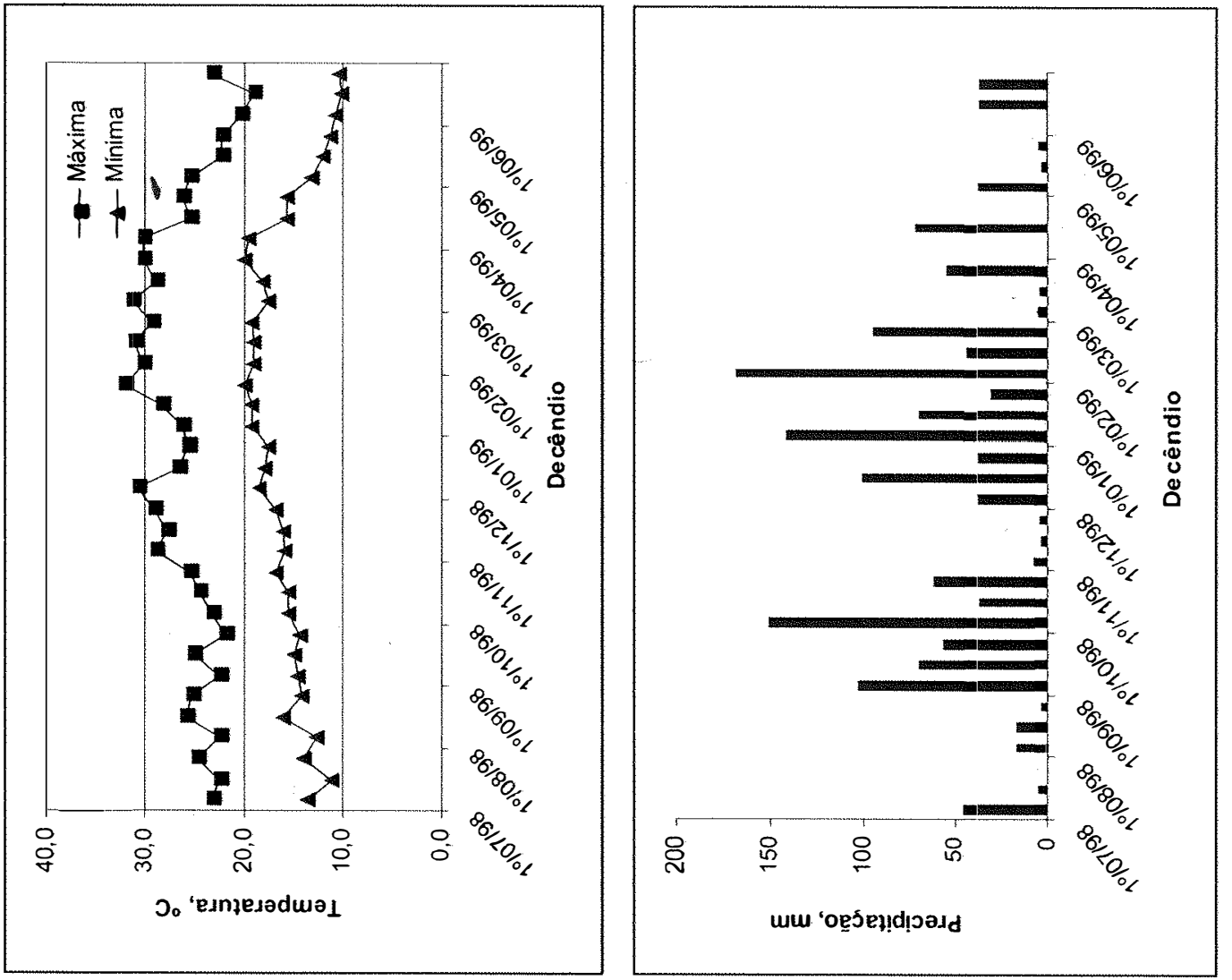

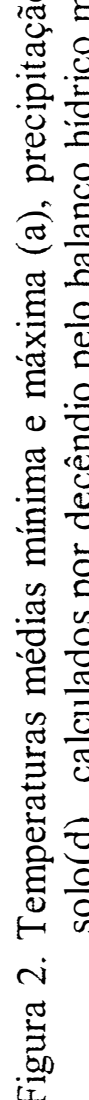



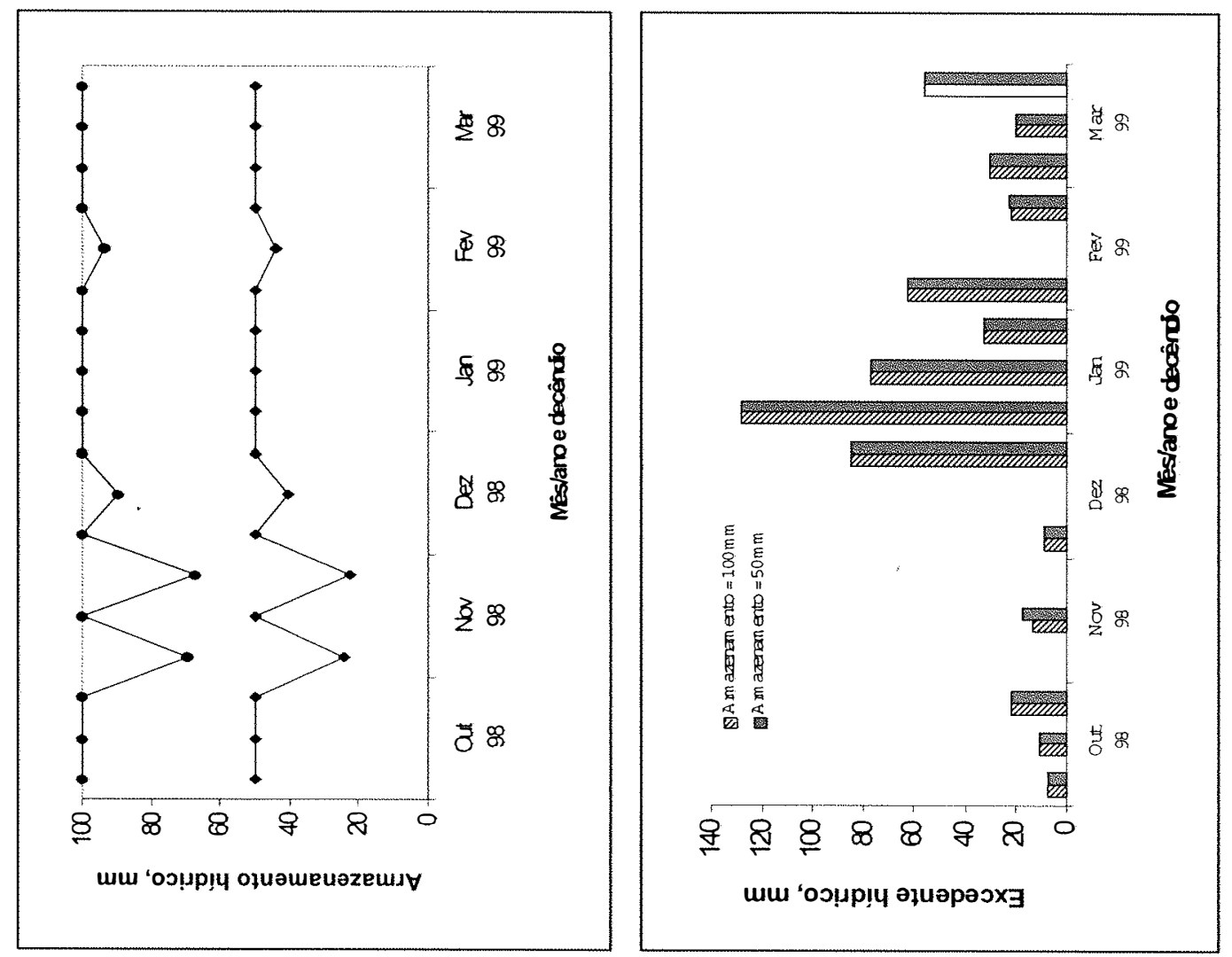

음

을 $\frac{2}{2}$ 를 若 过 is (두유 올 บิ 运 స्๊ 胥 ลิ ฮ : 章

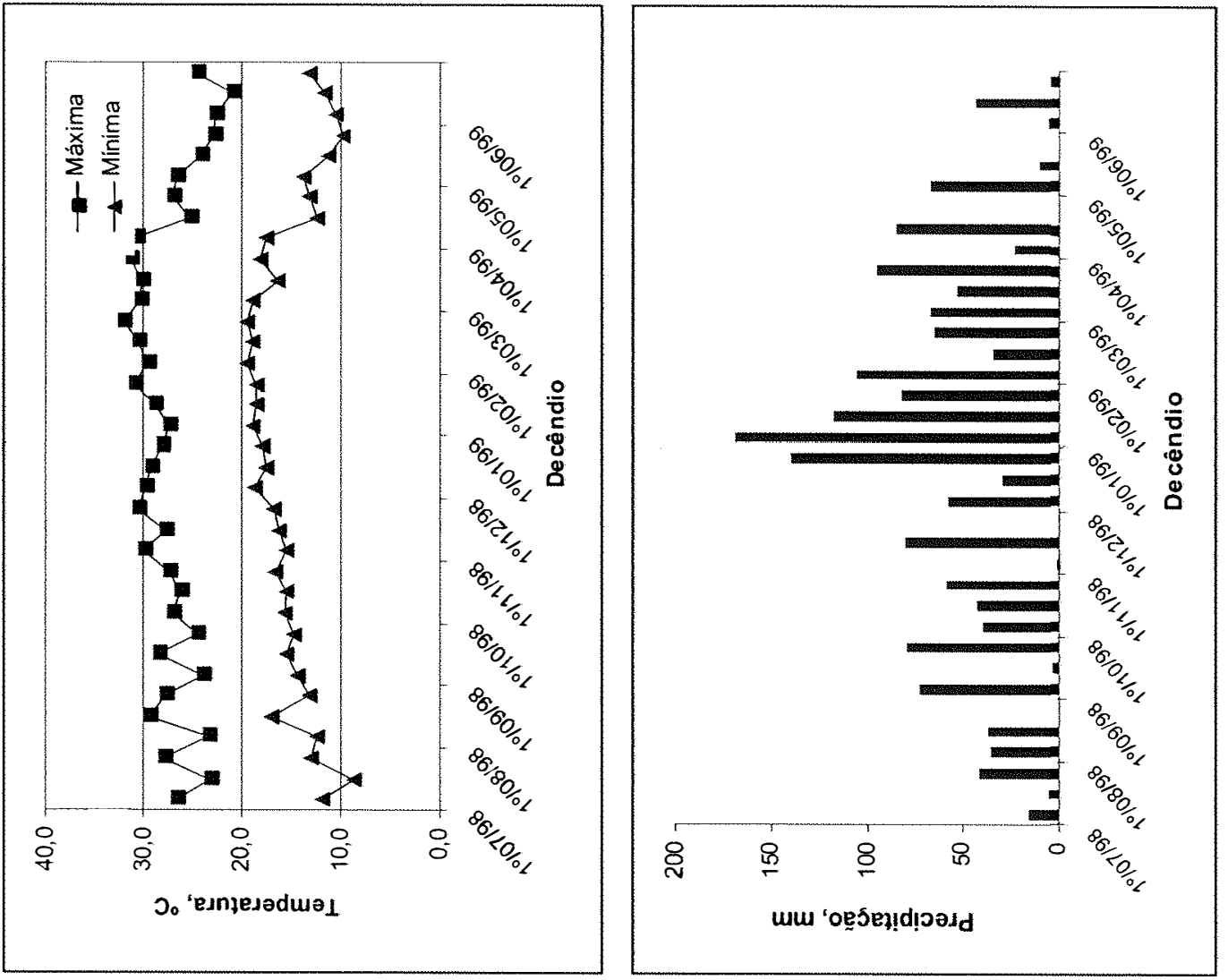
용 욜. 응 르 능 ิิ) สㅇำ 을 氖 \&) 류 일 흐 \% ఫृ 즉 ) 艺 芯 릉 응 $\dot{ }$ 물 

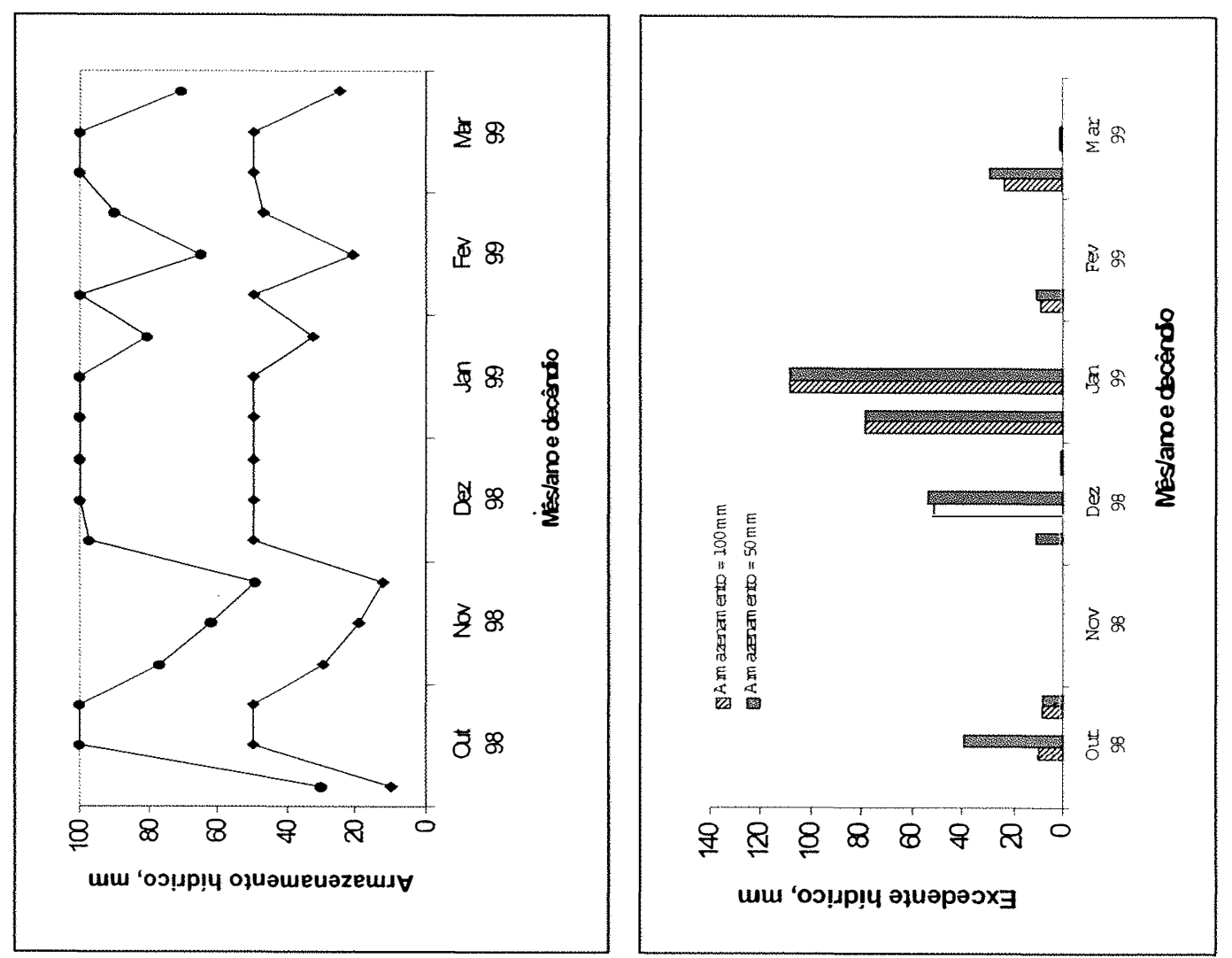

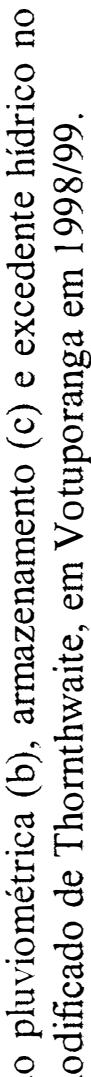

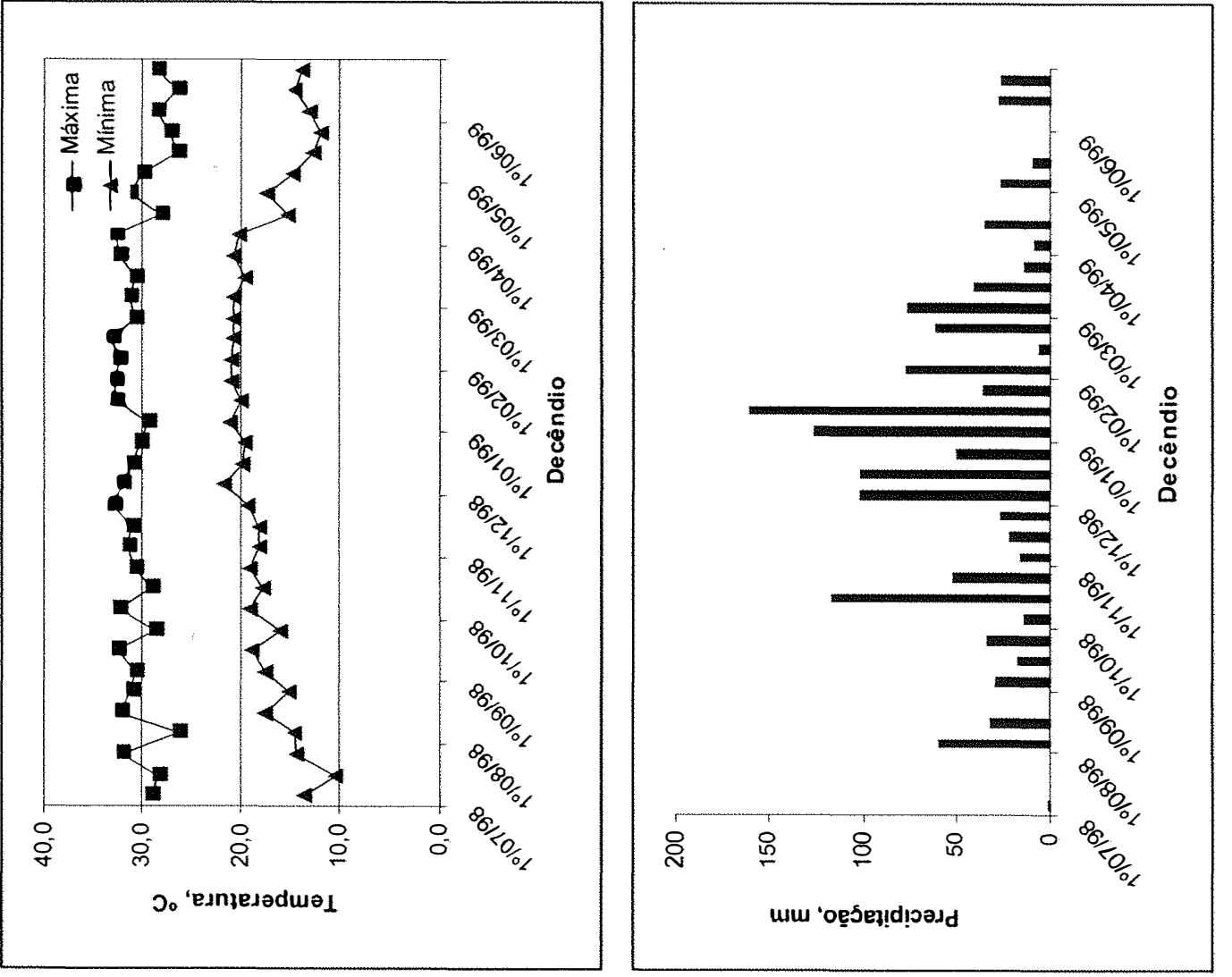

워 ह

盯

을

용

(동

고

일

坣

0 음

를

을

过

¿

त्व

氜

형

$\stackrel{0}{6}$

$\dot{\nabla}$

쿸 

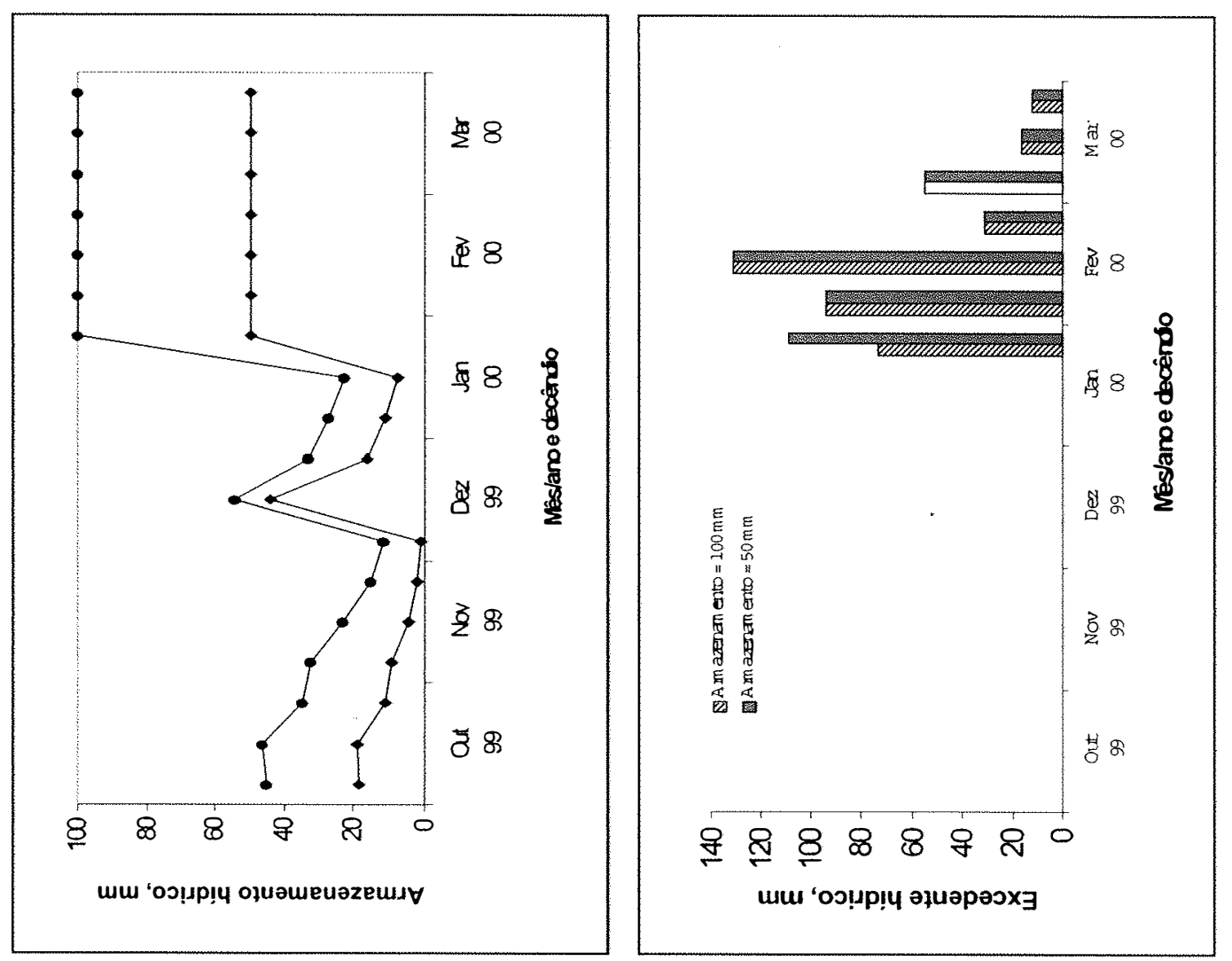

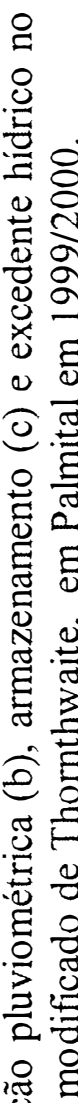
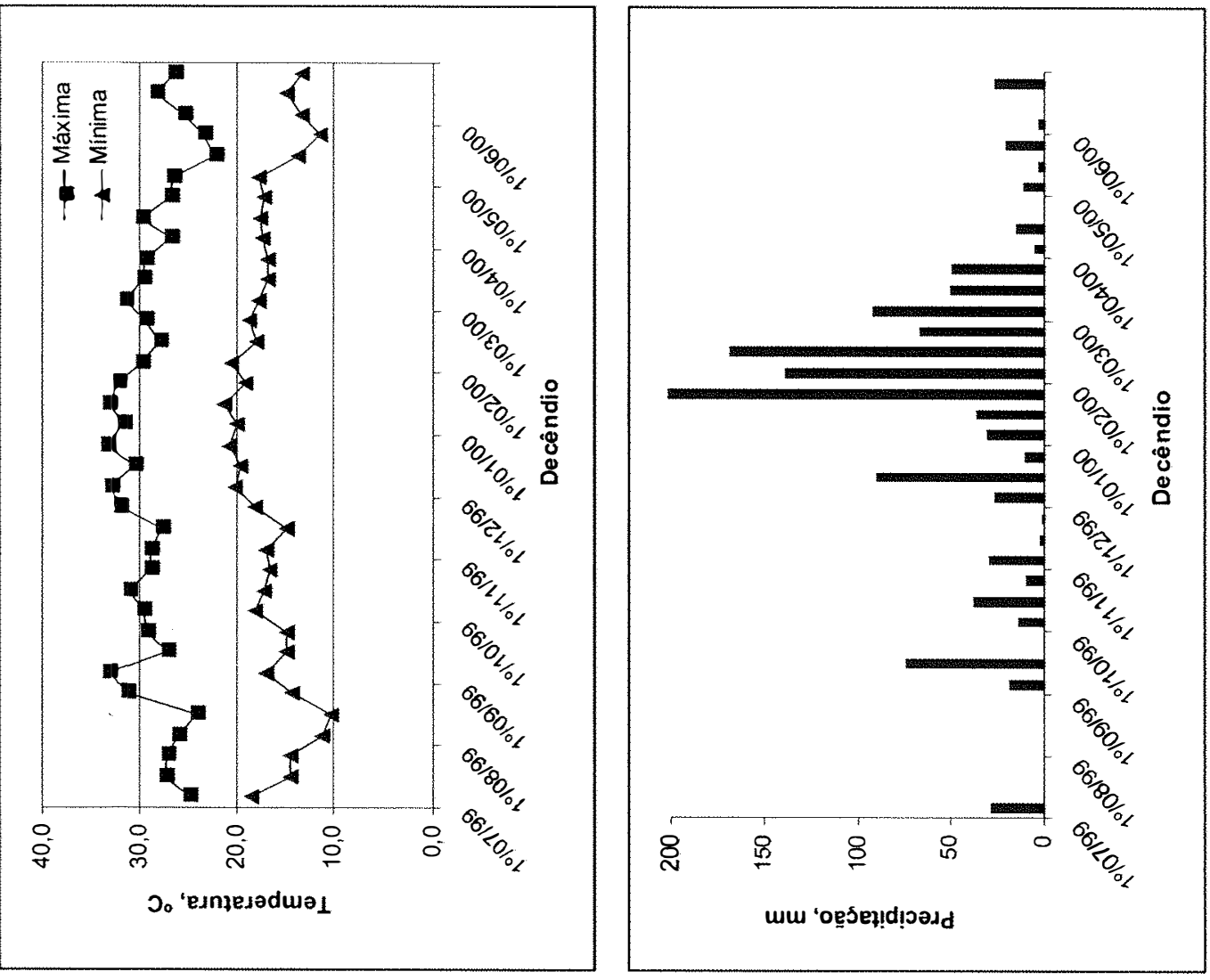

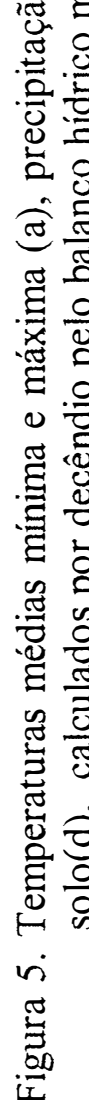



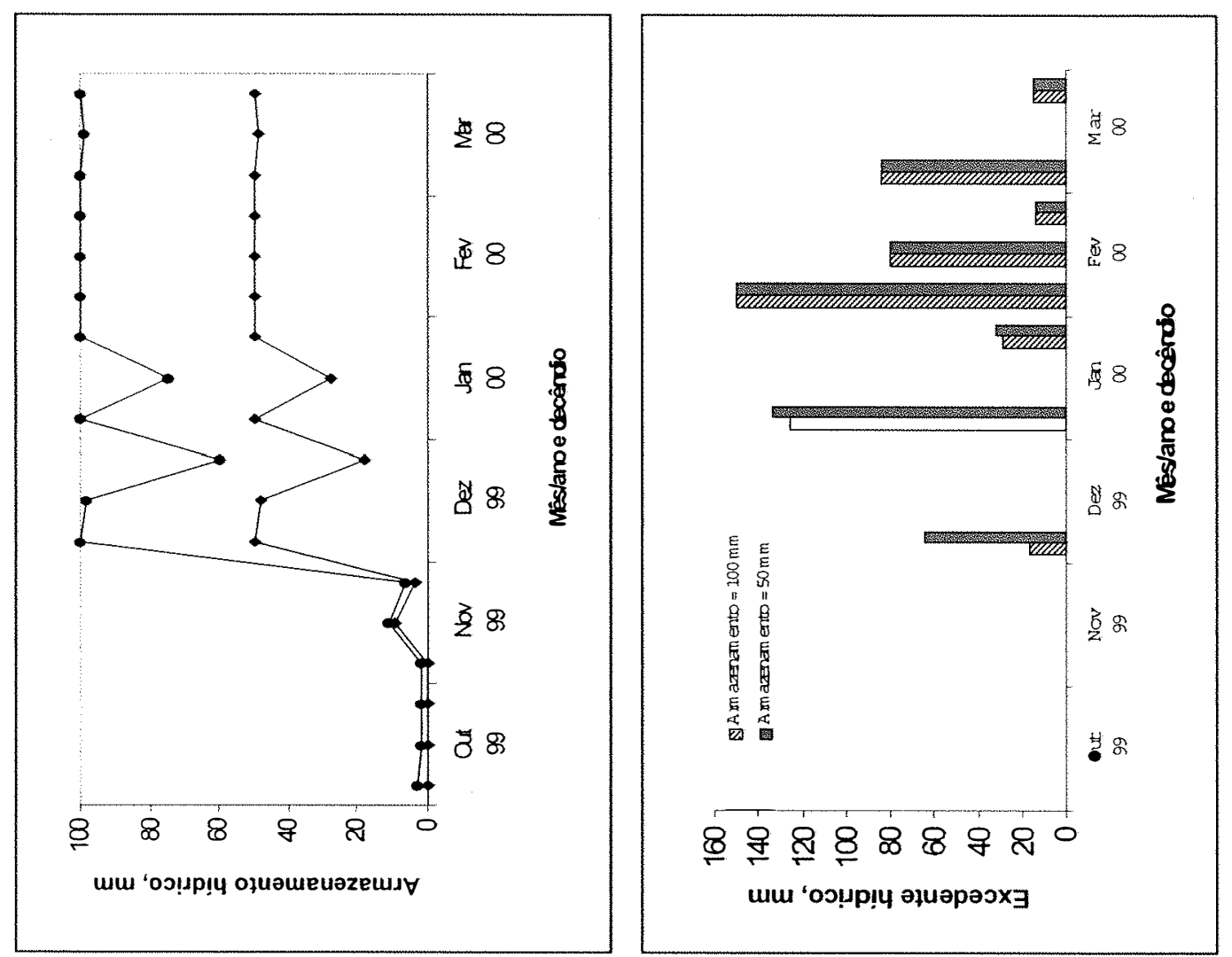

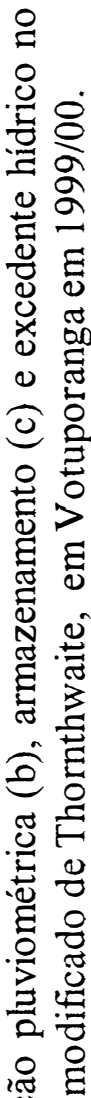
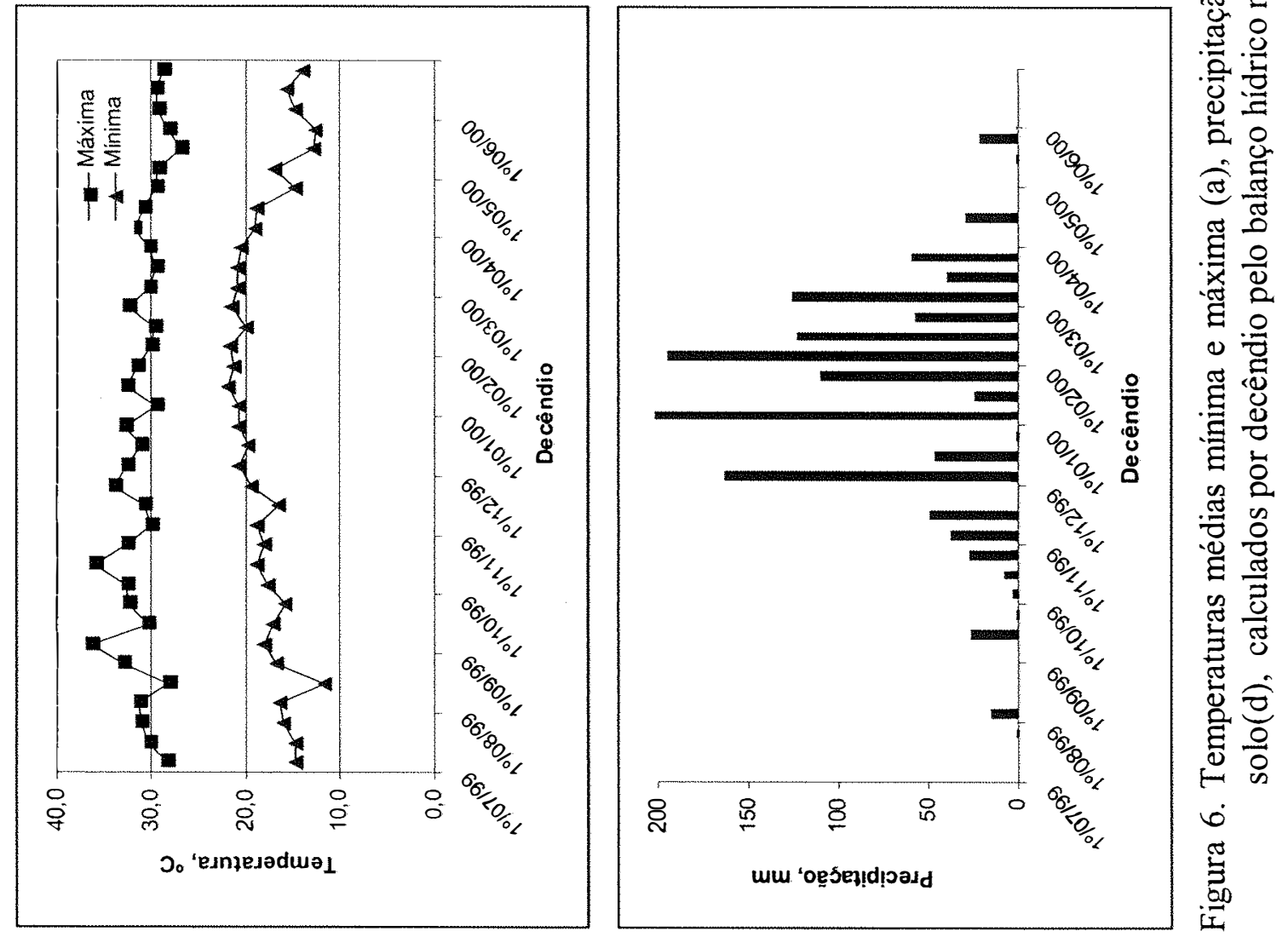

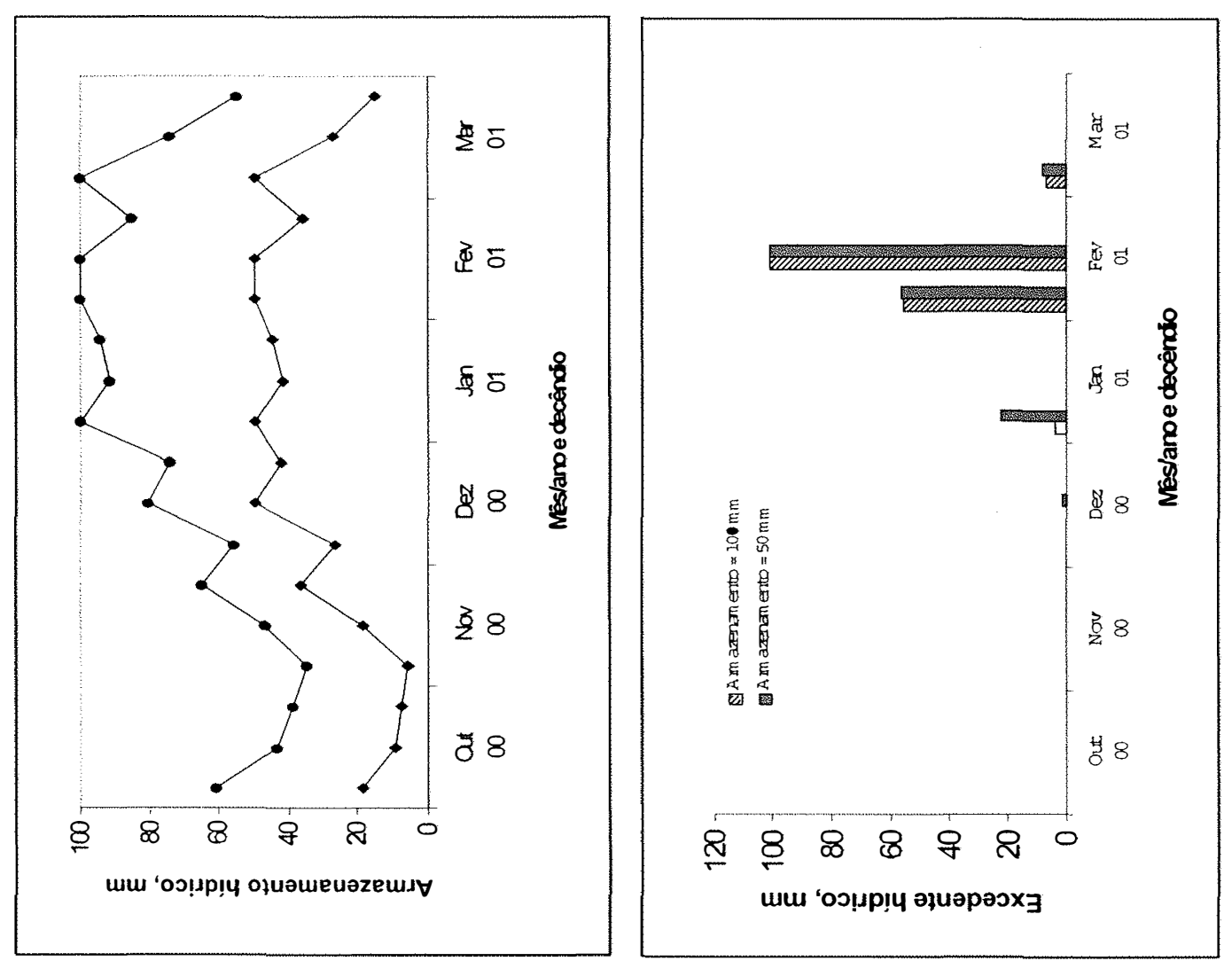

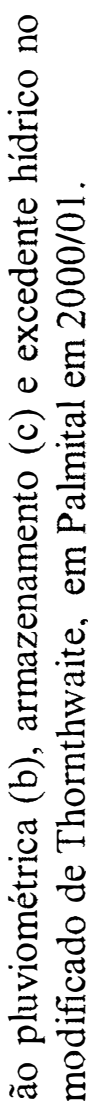
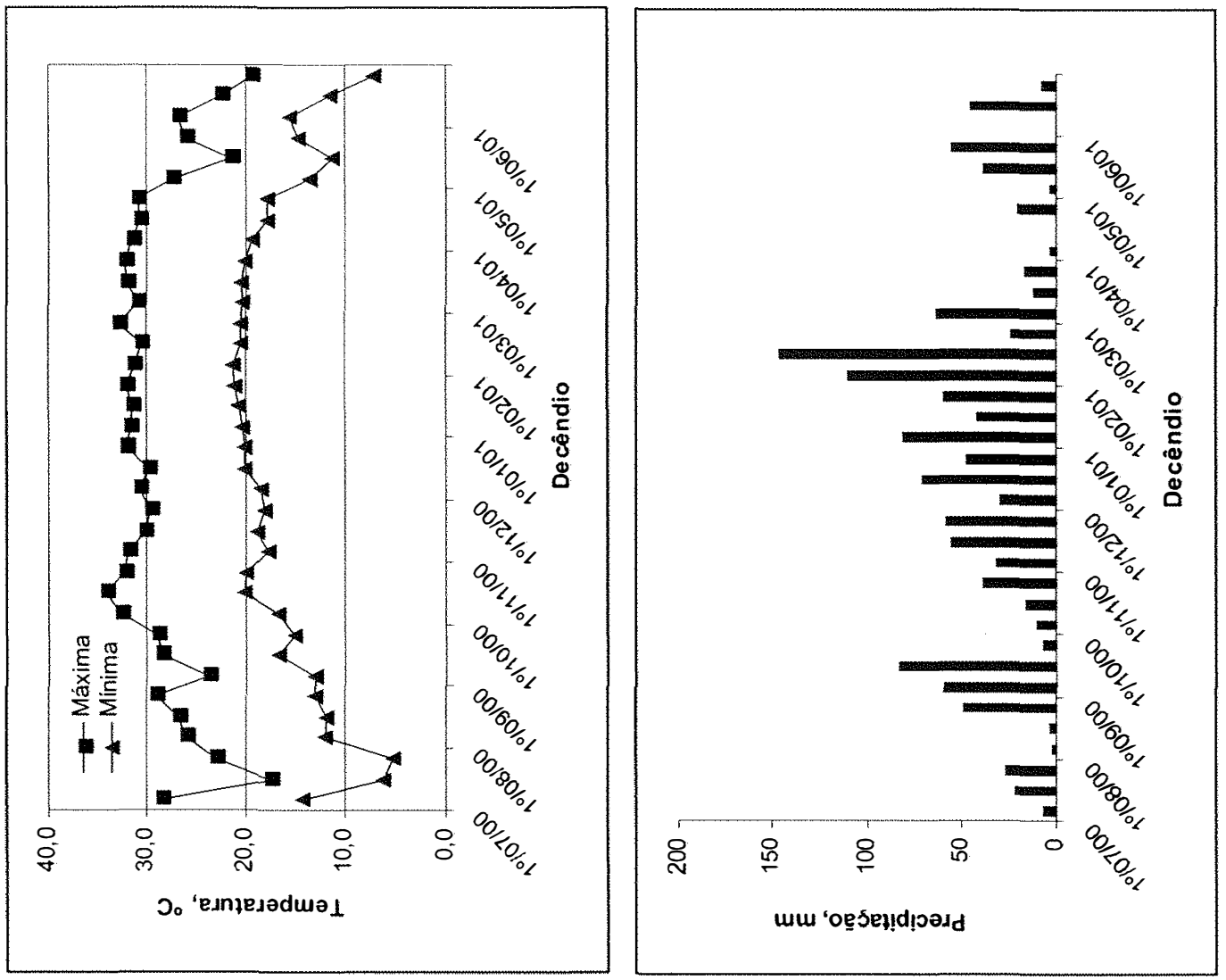

窝 

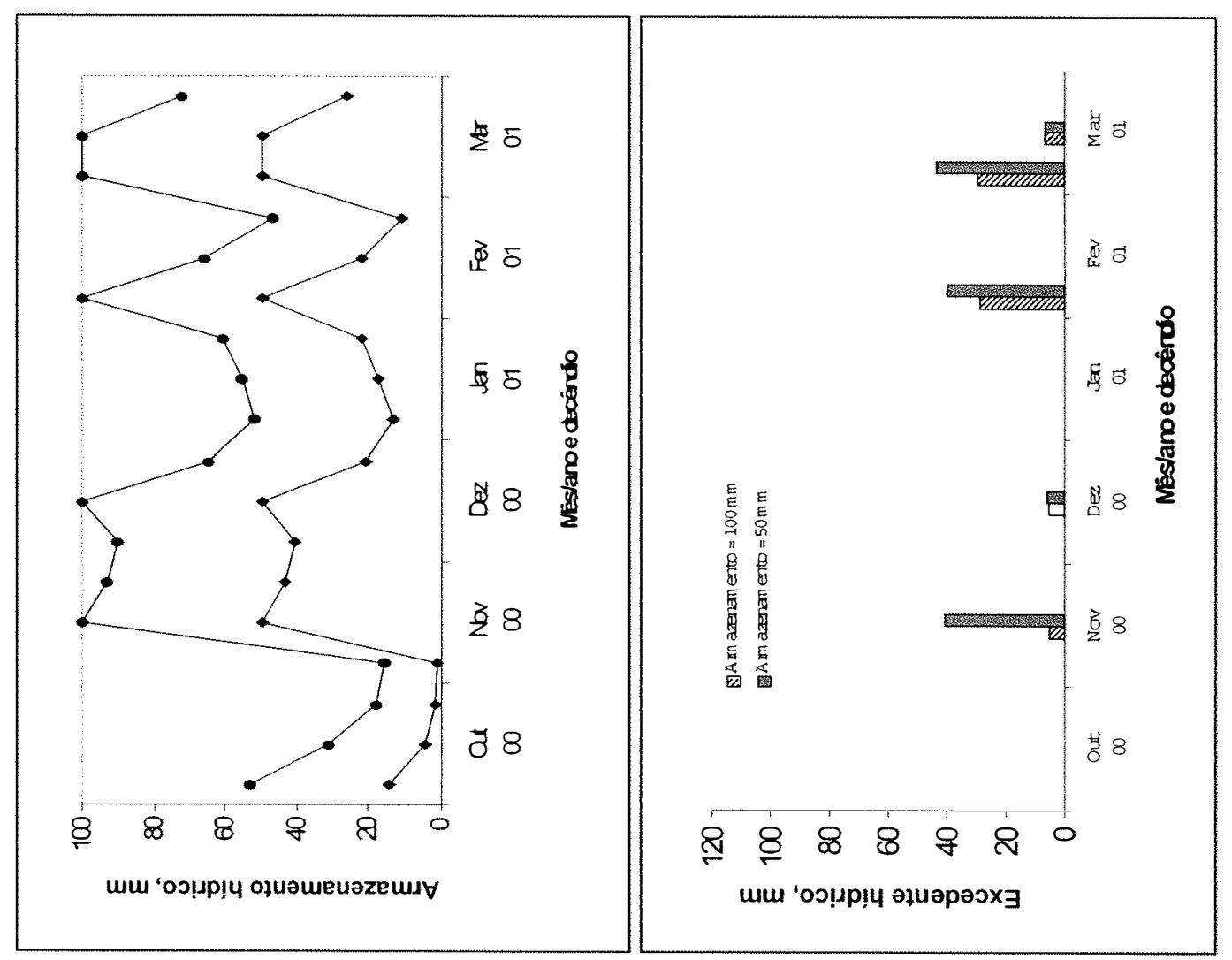

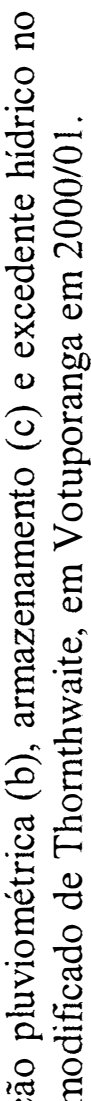
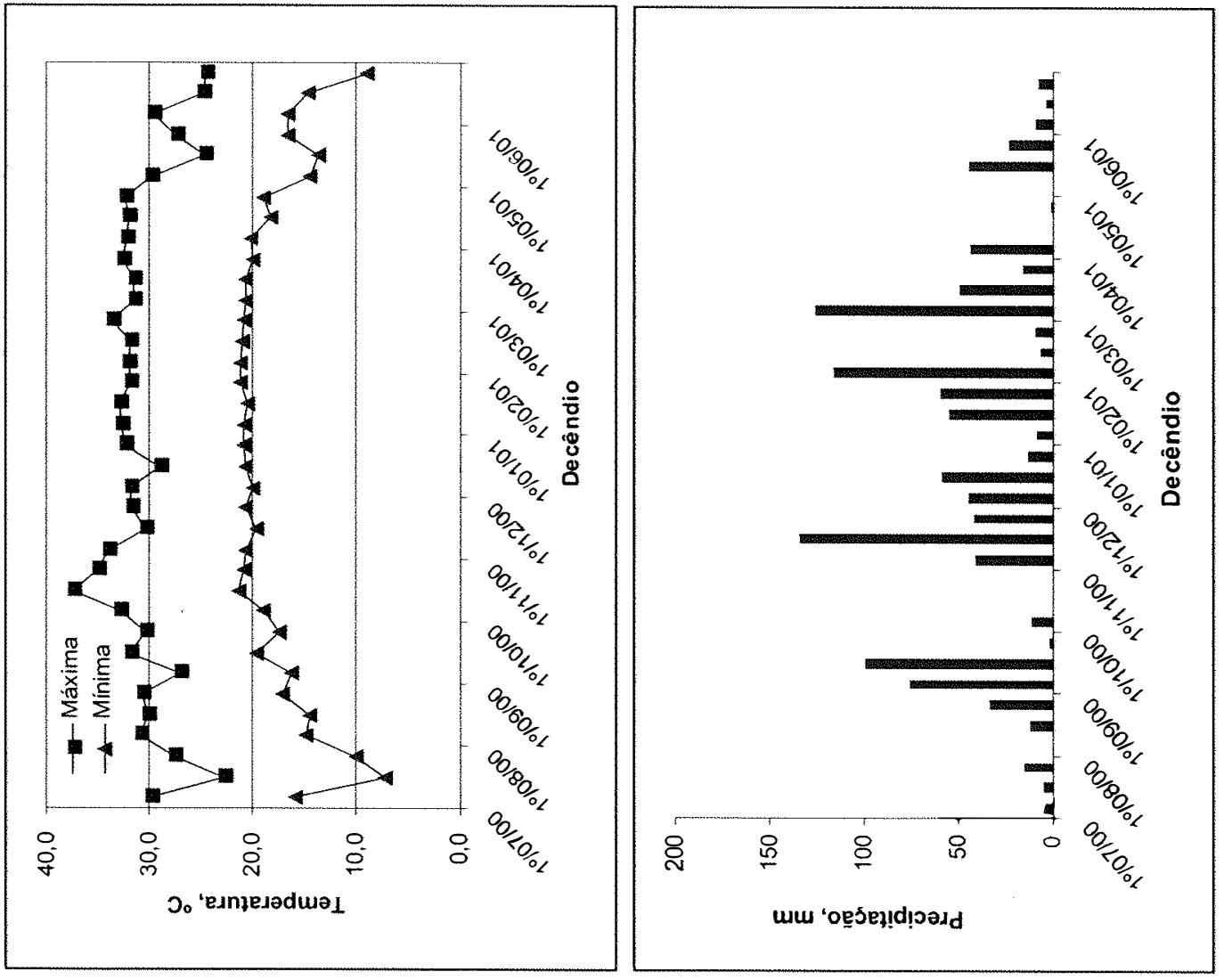

突 
A região noroeste do Estado de São Paulo apresenta temperaturas médias mínima e máxima anuais superiores às da região sudoeste. Embora a altitude de Itapeva seja superior à de Cândido Mota, as diferenças de temperatura entre estes locais foram pequenas na safra 1998/99. Outubro é o mês no qual a maioria dos agricultores procede a semeadura do milho de verão na região sudoeste do Estado, porém, em outubro de 1999 e 2000 as chuvas foram escassas e o armazenamento de água no solo pequeno. O mês de novembro também foi bastante seco nos anos 1998 e 1999. Os excedentes hídricos ocorreram a partir do último decêndio de dezembro ou de janeiro, dependendo do ano, mas foram inexpressivos em Votuporanga no ano agrícola 2000/01.

\subsubsection{Solos}

Os teores de argila, silte, areia grossa e areia fina foram, respectivamente, 180, 30, 520 e $270 \mathrm{~g} \mathrm{~kg}^{-1}$ em Votuporanga, 640, 270, 30 e $60 \mathrm{~g} \mathrm{~kg}^{-1}$ em Cândido Mota, 647, 220, 48 e $85 \mathrm{~g} \mathrm{~kg}^{-1}$ em Palmital -Branco Fadel e 640, 240, 50 e $70 \mathrm{~g} \mathrm{~kg}^{-1}$ em Palmital - Horto.

Os solos, com exceção de Votuporanga , eram ácidos em subsuperfície e apresentavam decréscimo acentuado do teor de fósforo da camada 0-20 para 20-40 $\mathrm{cm}$ (Tabelas 2 a 4). Em Itapeva, a acidez era extrema, com saturação por bases igual a 34\% na camada 0-20 cm. Os teores de matéria orgânica foram mais baixos em Votuporanga do que nos demais locais.

Os experimentos dos subprojetos Parcelamento e Partição foram desenvolvidos em áreas com razoável fertilidade natural na camada $0-20 \mathrm{~cm}$, mas contrastantes quanto à textura e ao teor de matéria orgânica. Conforme já apresentado, em Cândido Mota e Palmital os solos eram muito argilosos e em Votuporanga textura média. 


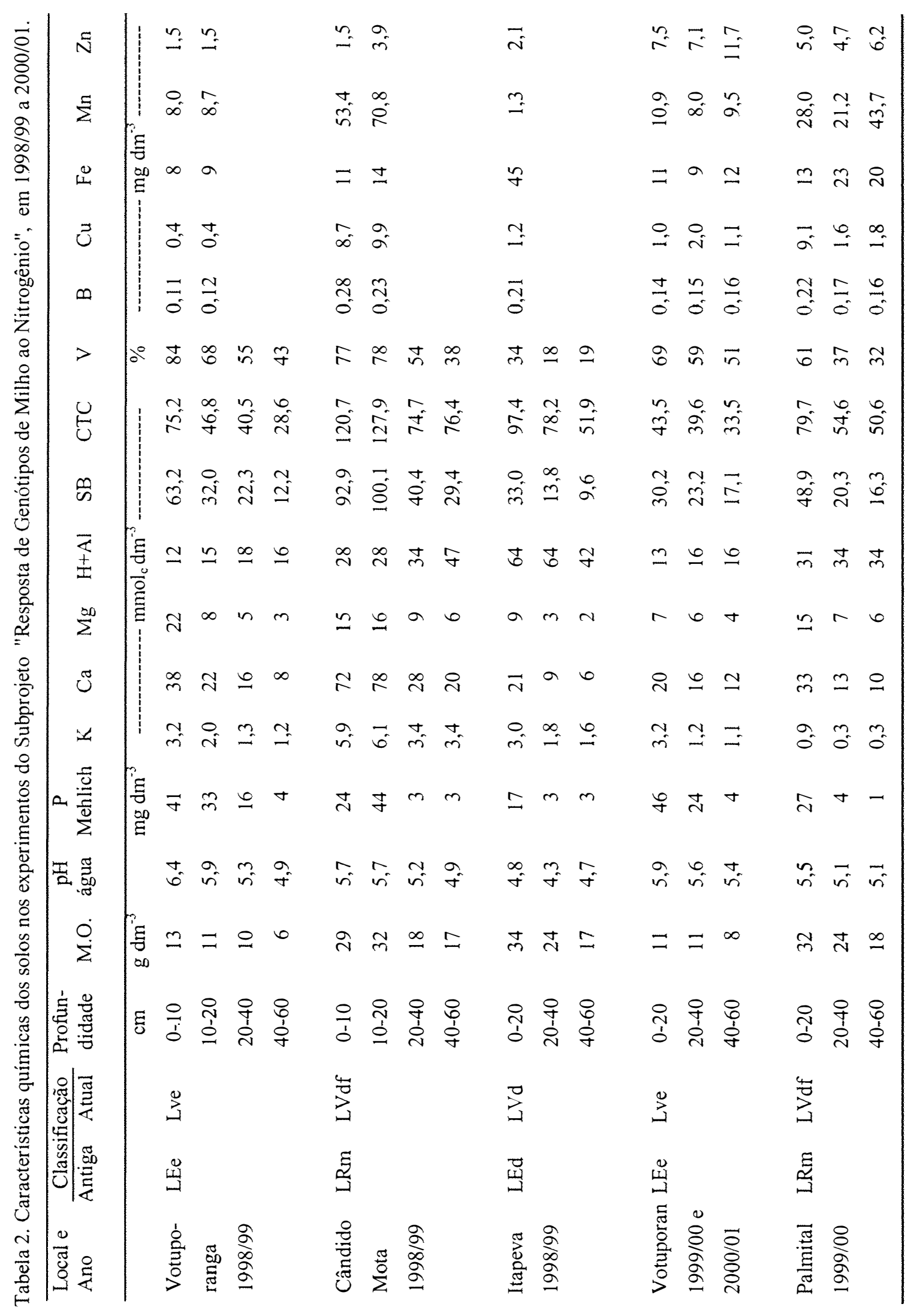



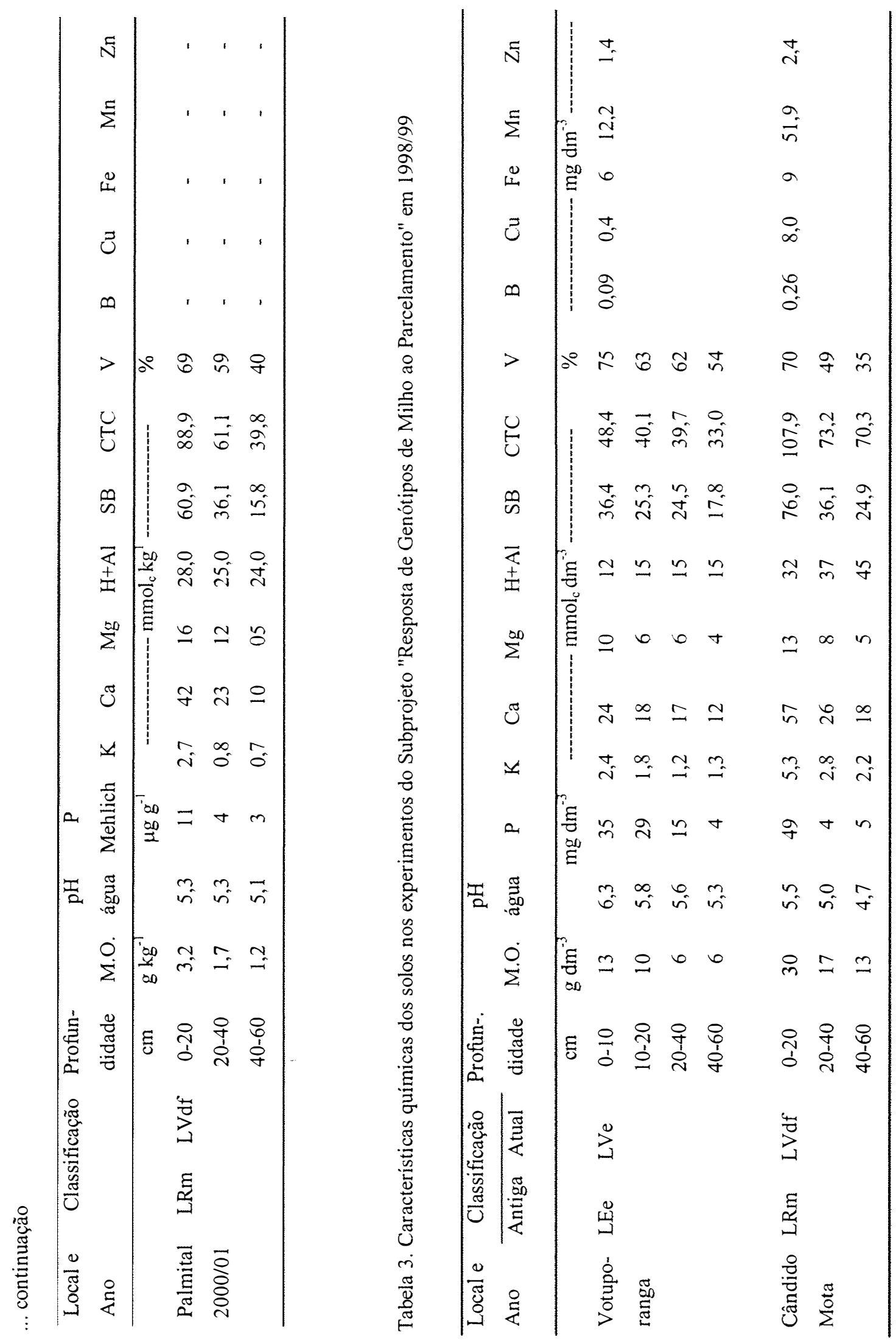


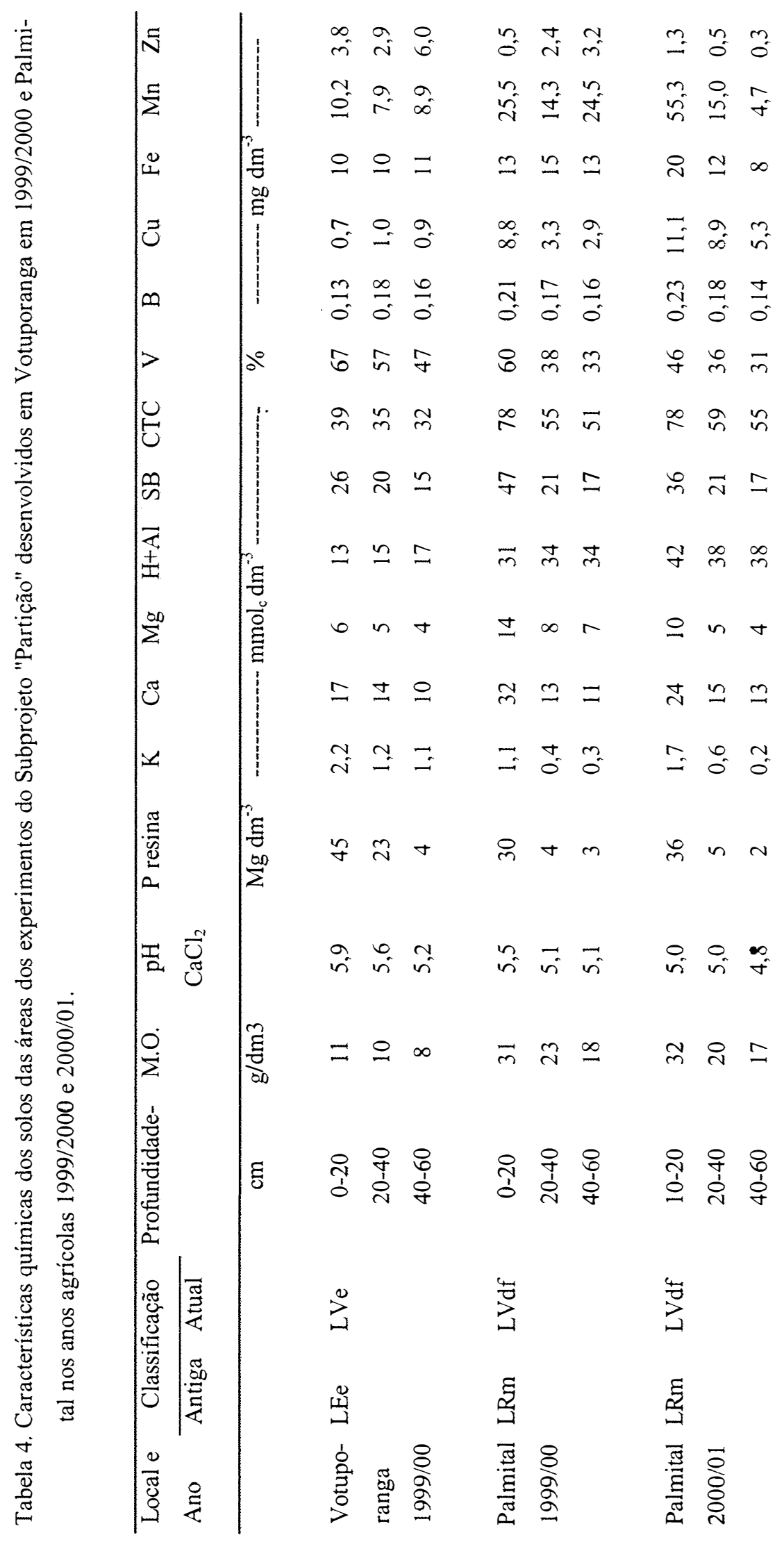




\subsection{Delineamento Experimental e Procedimentos de Campo}

\subsubsection{Subprojeto Genótipos x Nitrogênio - "Resposta de Genótipos de Milho ao Ni- trogênio"}

Foram desenvolvidos 7 experimentos com o delineamento de blocos ao acaso no esquema fatorial com quatro repetições, exceto em Cândido Mota 1998/99, cujo número de repetições foi três. Os tratamentos constituíram-se de dez genótipos de milho, do total de treze relacionados na Tabela 5, combinados com doses de nitrogênio. Embora algumas dessas cultivares tivessem sido renomeadas durante o desenvolvimento do trabalho $(\mathrm{C} 333 \mathrm{~B}=\mathrm{DKB} 333 \mathrm{~B}, \mathrm{IAC}$ V1 = IAC Airã, XL $251=$ DKB 251, Dina $766=$ DAS 766, CO 9560 = DAS 9560, BR 4157 = BRS 4157), empregaram-se os nomes originais na presente tese.

Empregaram-se cerca de $30 \mathrm{~kg} \mathrm{ha}^{-1}$ de nitrogênio na base (Tabela 6) e quatro doses de nitrogênio em cobertura: 0 (ausência de cobertura), 60, 120 e $180 \mathrm{~kg} \mathrm{ha}^{-1}$, na forma de uréia. A uréia foi aplicada superficialmente em faixa distante cerca de $20 \mathrm{~cm}$ da linha de semeadura.

O espaçamento foi $80 \mathrm{~cm}$ e a população inicial totalizou 57.500 plantas por hectare. Foram semeadas duas sementes por cova a cada $22 \mathrm{~cm}$, deixando-se uma planta a cada $22 \mathrm{~cm}$ após o desbaste. As sementes foram tratadas com inseticida Futur (thiodicarb + micronutrientes) para o controle das pragas inicias e, quando necessário, realizadas pulverizações para o controle da lagarta do cartucho (Spodoptera frugiperda). Em Votuporanga 2000/01 aplicaram-se $30 \mathrm{~kg} \mathrm{ha}^{-1}$ de Furadan (carbofuran) no sulco de semeadura para evitar os danos do nematóide Pratyclenchus sp.

Em Cândido Mota e Palmital a semeadura foi procedida entre 15 e 25 de outubro nos três anos agrícolas (Tabela 6). Já em Votuporanga, a semeadura foi realizada no início de novembro em 1998 e no último decêndio de novembro nos dois anos seguintes. Em Itapeva o experimento foi implantado mais tardiamente, no início do mês de dezembro. No momento da semeadura, amostraram-se as camadas 0-20 e 20-40 cm do solo para análise do $\mathrm{N}$ inorgânico no solo ( $\mathrm{N}$-amônio e $\mathrm{N}$-nitrato), menos em Votuporanga 
Tabela 5. Caracterização dos cultivares de milho e períodos em que foram avaliados em Itapeva, Cândido Mota, Palmital e Votuporanga no subprojeto genótipos x nitrogênio.

\begin{tabular}{lcccc}
\hline Genótipo & $\begin{array}{c}\text { Empresas e } \\
\text { instituições }\end{array}$ & $\begin{array}{c}\text { Tipo de } \\
\text { cruzamento }^{(1)}\end{array}$ & $\begin{array}{c}\text { Germoplasma } \\
\text { predominante }\end{array}$ & $\begin{array}{c}\text { Ano de } \\
\text { avaliação }\end{array}$ \\
\hline P 32R21 & Pioneer & HS & Temperado & $98 / 99$ \\
IAC V1 & IAC & V & Tropical & $98 / 99$ \\
XL 212 & Dekalb & HS & Temperado & $98 / 99$ \\
BR 3123 & Embrapa & HT & Tropical & $98 / 99$ a 00/01 \\
Dina 766 & Dow AgroSciences & HT & Intermediário (I) & $98 / 99$ a 00/01 \\
AG 1051 & Agroceres & HD & Tropical & $98 / 99$ a 00/01 \\
XL 251 & Dekalb & HT & Tropical / I & $98 / 99$ a 00/01 \\
C 333B & Dekalb & HSm & Tropical & $98 / 99$ a 00/01 \\
Master & Syngenta Seeds & HT & Tropical / I & $98 / 99$ a 00/01 \\
BR 4157 ${ }^{(2)}$ & Embrapa & V & Tropical & $98 / 99$ a 00/01 \\
8410 & Dow AgroSciences & HS & Intermediário & $99 / 00$ e 00/01 \\
Tork & Syngenta Seeds & HS & Tropical / I & $99 / 00$ e 00/01 \\
CO 9560 & Dow AgroSciences & HS & Tropical & $99 / 00$ e 00/01 \\
\hline
\end{tabular}

(1) Tipo de germoplasma: $\mathrm{HS}$ = híbrido simples; $\mathrm{HSm}$ = híbrido simples modificado; $\mathrm{HT}$ = híbrido triplo; $\mathrm{HD}=$ híbrido duplo e $\mathrm{V}=$ variedade

(2) Substituído pela Exceler em Cândido Mota em 1998/99

2000/01, onde não foi feita amostragem. Em Votuporanga 1998/99 e Cândido Mota $1998 / 99$ amostrou-se também a camada $20-40 \mathrm{~cm}$.

Avaliaram-se a produtividade de grãos e o conteúdo e exportação de N nos grãos das dez cultivares incluídas em cada experimento. Porém, a produtividade e a exportação de $\mathrm{N}$ nos grãos da cultivar P 32R21 não foram calculados em Itapeva porque o seu estane foi desuniforme, determinando-se apenas o $\mathrm{N}$ nos grãos. 


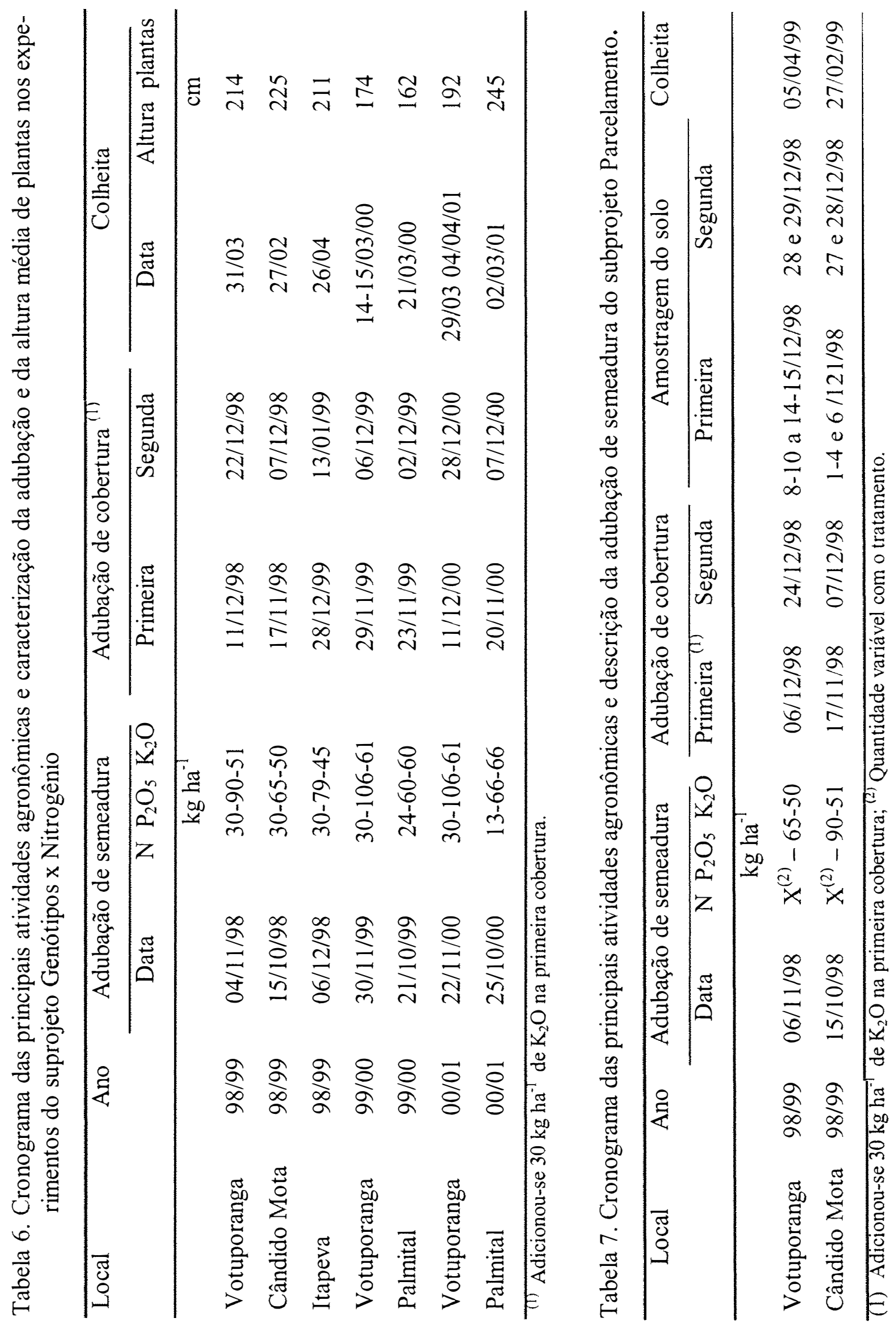




\subsubsection{Subprojeto Parcelamento - "Resposta de Genótipos de Milho ao Parcelamen- to e Doses de Nitrogênio"}

Foi estudado, em dois experimentos, o efeito de doses de nitrogênio no sulco de semeadura e em cobertura sobre a produtividade de grãos e o conteúdo de $\mathrm{N}$ nos grãos ou folhas das cultivares. O delineamento foi o de blocos ao acaso com três repetições em Cândido Mota e o de blocos ao acaso no esquema fatorial com parcelas subdivididas e quatro repetições em Votuporanga, sendo que as parcelas foram constituídas pelas doses de $\mathrm{N}$ na semeadura (base) e as subparcelas pela quantidade total de $\mathrm{N}$ (base + cobertura) e cultivares. Empregaram-se os genótipos BR 3123, XL 212, C333B e Master, também utilizados no estudo anterior, e 10 tratamentos com nitrogênio descritos na Tabela 8 . Utilizou-se o nitrato de amônio nas adubações de cobertura.

O espaçamento foi $80 \mathrm{~cm}$ e a população inicial totalizou 57.500 plantas por hectare. As datas das principais operações agronômicas encontram-se na Tabela 7. As parcelas foram constituídas de 4 linhas de 6,0 $\mathrm{m}$ de comprimento, colhendo-se 4,0 $\mathrm{m}$ das 2 linhas centrais para as avaliação da produtividade de grãos. Procedeu-se a semeadura e o controle de pragas da mesma maneira que no subprojeto genótipos x nitrogênio.

No momento da semeadura, foram retiradas amostras para caracterização do $\mathrm{N}$ inorgânico do solo (nitrato e amônio) nas camadas $0-20 \mathrm{~cm}, 20-40 \mathrm{~cm}$ e $40-60 \mathrm{~cm}$. O solo também foi amostrado durante o desenvolvimento da cultura, em duas épocas distintas: imediatamente antes da segunda cobertura, cerca de 30 dias após a semeadura, e próximo de 15 dias após o florescimento masculino, na mesma faixa onde o adubo de cobertura foi aplicado. As profundidades foram as mesmas da amostragem inicial, subdividindo-se a camada superficial em 0-10 e 10-20 cm apenas no experimento desenvolvido em Votuporanga em 1998/99. A amostragem composta (12 subamostras), independente da cultivar, incluiu as parcelas correspondentes às seguintes doses na semeadura $\mathrm{e}$ cobertura, em kg ha ${ }^{-1}$ : zero, $0+60,60+0,60+180$ e 120+120. As amostras foram imediatamente congeladas e assim mantidas até o momento das análises.

Em Cândido Mota 1998/99, amostraram-se folhas da espiga aos 30 dias após o florescimento e, em Votuporanga 1998/99, amostraram-se grãos debulhados. Determinouse o conteúdo de $\mathrm{N}$ nesses tecidos e calculou-se a exportação de $\mathrm{N}$ nos grãos por área. 
Tabela 8. Doses e parcelamentos do nitrogênio utilizados no Subprojeto"Resposta de Genótipos de Milho ao Parcelamento e Doses de Nitrogênio"

\begin{tabular}{lccc}
\hline Tratamento & Total & $\begin{array}{c}\text { Dose de nitrogênio } \\
\text { Base }\end{array}$ & $1^{\mathrm{a}} \mathrm{e}^{\mathrm{a}}{ }^{\mathrm{a}}$ coberturas \\
\hline T1 & 0 & 0 & $(0+0)$ \\
T1" (1) & 0 & 0 & $(0+0)$ \\
T2 & 60 & 0 & $(30+30)$ \\
T3 & 120 & 0 & $(60+60)$ \\
T4 & 180 & 0 & $(90+90)$ \\
T5 & 60 & 60 & $(0+0)$ \\
T6 & 120 & 60 & $(30+30)$ \\
T7 & 180 & 60 & $(60+60)$ \\
T8 & 240 & 60 & $(90+90)$ \\
T9 & 240 & 120 & $(60+60)$ \\
\hline
\end{tabular}

(1) Testemunha adicional para permitir a análise dos contrastes ortogonais, comparando a aplicação somente em cobertura com a aplicação na base + cobertura

\subsubsection{Subprojeto Partição na Planta -"Acúmulo e Partição do Nitrogênio em Genó- tipos de Milho"}

Foram desenvolvidos três experimentos, sendo um em Votuporanga (1999/2000) e dois em Palmital (1999/2000 e 2000/2001). O delineamento experimental foi o de blocos ao acaso no esquema fatorial, com 20 tratamentos e quatro repetições, totalizando 80 parcelas. Empregaram-se cinco cultivares de milho, sendo três tipicamente originadas de clima tropical (AG 1051, BR 3123 e BRS 4157), denominadas tropicais, e duas com germoplasma de clima temperado e submetidas a programa de adaptação às condições brasileiras (XL 212 e P32R21), denominadas temperadas, ambas com diferentes padrões de resposta ao nitrogênio (Duarte et al., 1988). A variedade BR 4157, também denominada Sol-da-Manhã Nitroflint, foi desenvolvida em condições de baixa fertilidade do solo (Machado \& Magalhães,1995; Machado et al., 1998ab). Essa variedade é considerada eficiente no uso do nitrogênio, e suas sementes são indicadas para agricultores familiares que têm problemas de estresse no solo relacionados ao N (Embrapa, s.d.). 
Empregaram-se quatro doses de $\mathrm{N}$ aplicadas em cobertura: 0,60,120 e $180 \mathrm{~kg}$ $\mathrm{ha}^{-1}$. Essas doses foram parceladas metade no estádio de 6 folhas totalmente desdobradas e o restante no estádio de 8 a 10 folhas, adicionando-se $30 \mathrm{~kg} \mathrm{ha}^{-1}$ de $\mathrm{K}_{2} \mathrm{O}$ na primeira cobertura. Utilizaram-se o nitrato de amônio e o $\mathrm{KCl}$ como fertilizantes de cobertura.

Procedeu-se a semeadura e o controle de pragas da mesma maneira que nos subprojeto anteriores. Como os materiais com germoplasma predominantemente de clima temperado apresentam maior suscetibilidade às principais doenças que ocorrem no Estado de São Paulo, especialmente a ferrugem polissora (Puccinia polysora) e a pinta branca causada pelo fungo Phaeosphaeria maydis, foram realizadas pulverizações com fungicidas para evitar possíveis danos. Procederam-se três pulverizações seqüenciais com os produtos comerciais, doses e períodos descritos a seguir: Folicur PM (ingrediente ativo: tebuconazole, sistêmico do grupo dos triazóis, $250 \mathrm{~g} / \mathrm{kg}$ ), $30 \mathrm{ml}$ em 20 litros de água aos 30 dias após a semeadura; Alto 100 (ingrediente ativo: cyproconazole, sistêmico e de contato do grupo dos triazóis, $100 \mathrm{~g} / \mathrm{L}$ ), $30 \mathrm{ml}$ em 20 litros de água aos 45 dias após a semeador); Amistar 500 WG (ingrediente ativo: azoxystrobin, sistêmico do grupo da estrobilurina, $500 \mathrm{~g} / \mathrm{kg}$ ), $5 \mathrm{~g}$ em 20 litros de água aos 52/60 dias após a semeadura.

Os experimentos deste subprojeto foram instalados no período de 29 de outubro a 15 de novembro dos anos 1999 e 2000 (Tabela 9).As parcelas tiveram 4 linhas de 10,0 metros de comprimento, empregando-se as duas linhas centrais para as avaliações. O espaçamento foi de $80 \mathrm{~cm}$, e a população, de 57.500 plantas por hectare, exceto em Palmital 2000/01. Nessa localidade, o espaçamento foi de $90 \mathrm{~cm}$, e a população, de 55.000 plantas por hectare.

Da mesma maneira que nos subprojetos anteriores, as camadas 0-20 e 20-40 cm do solo foram amostradas para caracterização do $\mathrm{N}$ inorgânico do solo (nitrato e amônio) no momento da semeadura. Em Palmital 2000/01 também amostrou-se a camada 40-60 cm. Durante o desenvolvimento da cultura, as camadas 0-20, 20-40 e 40-60 cm foram amostradas em duas épocas distintas: imediatamente antes da segunda cobertura, e próximo do florescimento masculino, na mesma faixa onde o adubo de cobertura foi aplicado. Enquanto em Palmital 2000/01 a mostragem foi realizada imediatamente antes do florescimento, em Palmital 1999/00 e Votuporanga 1999/00 foi feita cerca de 15 dias após 
Tabela 9. Cronograma de execução dos experimentos no campo e principais estádios da cultura do milho em Votuporanga (SP), no ano agrícola 1999/2000, e Palmital (SP) nos anos agrícolas 1999/2000 e 2000/01

\begin{tabular}{|c|c|c|c|}
\hline \multirow[b]{2}{*}{ Operações e eventos } & \multicolumn{3}{|c|}{ Experimento } \\
\hline & Votuporanga 1999/00 & Palmital 1999/00 & Palmital $2000 / 01$ \\
\hline Semeadura & $29 / 10 / 99$ & $6 / 11 / 99$ & $15 / 11 / 00$ \\
\hline Emergência & $4 / 11 / 99$ & $13 / 11 / 99$ & $22 / 11 / 00$ \\
\hline $1^{\text {a }}$ Adubação de cobertura & 29 e $30 / 11 / 99$ & $3 / 12 / 99$ & $06 / 12 / 00$ \\
\hline $1^{\text {a }}$ Amostragem solo & 03 e $04 / 12 / 99$ & 15 e $16 / 12 / 99$ & 20 a $22 / 12 / 00$ \\
\hline $2^{a}$ Adubação de cobertura & $06 / 12 / 99$ & $17 / 12 / 99$ & $23 / 12 / 00$ \\
\hline Florescimento & $27 / 12 / 99$ a $05 / 01 / 00$ & 10 a $21 / 01 / 00$ & 10 a $18 / 01 / 01$ \\
\hline $2^{\mathrm{a}}$ Amostragem solo & 20 e $21 / 01 / 00$ & 27 e $28 / 01 / 00$ & 05 a $07 / 01 / 01$ \\
\hline Maturação Fisiológica & 08 a $24 / 02 / 00$ & $18 / 02$ a $02 / 03 / 00$ & 01 a 19/03/01 \\
\hline Colheita grãos & 20 e $21 / 03 / 00$ & - & $13 / 04 / 01$ \\
\hline
\end{tabular}

este estádio. A amostragem composta (12 subamostras) envolveu apenas o fator nitrogênio (doses de $\mathrm{N}$ em cobertura), independentemente da cultivar. As amostras foram imediatamente congeladas e assim mantidas até o momento das análises.

Realizaram-se as amostragens das plantas nos estádios final do florescimento masculino (todas as plantas com pendão) e maturação fisiológica dos grãos (presença de camada preta na base do grãos) em 1,0 m das duas linhas centrais (dez plantas por parcela), separando-se e determinando-se a produção de massa verde das diferentes partes da planta, a saber: folhas, colmos + pendão e espigas. Na maturação, as folhas foram separadas em verdes e secas, e as espigas, em grãos, sabugos e brácteas. Com exceção dos grãos, as frações foram picadas para coleta de amostras e secadas em estufa a $60^{\circ} \mathrm{C}$, determinando-se o teor de matéria seca de cada uma das partes. Para o estudo de fracionamento da planta, as folhas secas e verdes foram consideradas como fração folha, e as brácteas, sabugos e grãos, como fração espiga. Determinou-se o $\mathrm{N}$ total nas frações, como descrito no item 3.3, e calculou-se o acúmulo de $\mathrm{N}$ na massa seca de dez plantas. A 
partir dos valores totais acumulados no final do florescimento masculino e na maturação dos grãos, calculou-se também o acúmulo relativo neste subperíodo (expresso em percentagem do total acumulado durante o ciclo da planta). Ressalte-se que as datas das colheitas foram diferentes para a maioria das cultivares em função da heterogeneidade do ciclo.

As espigas das dez plantas colhidas no estádio de maturação fisiológica foram avaliadas quanto ao número de fileiras e de grãos por fileira. Após a debulha manual dos grãos, avaliaram-se o diâmetro e comprimento do sabugo e a massa de cem grãos, bem como a massa de grãos por espiga. Calcularam-se os valores médios desses parâmetros para cada parcela e estimou-se, a partir da massa de grãos por espiga e do número médio de espigas por planta, a produtividade de grãos por hectare. Nos experimentos Votuporanga 1999/00 e Palmital 2000/0, foram colhidas espigas quando a umidade dos grãos era menor de $23 \%$, em 4,0 m das duas linhas centrais, para a avaliação da produtividade.

A eficiência de uso do $\mathrm{N}$ na planta foi calculada através dos métodos descritos por Siddiqui et al. (1981) e Moll et al. (1982), cujos parâmetros foram denominados, respectivamente, eficiência de uso do $\mathrm{N}$ no vegeral (Eficiência no vegetal) e proporção do $\mathrm{N}$ acumulado nos grãos expresso como porcentagem do acúmulo de $\mathrm{N}$ na planta ( $\mathrm{N}$ grãos / $\mathrm{N}$ planta). Essa proporção foi calculada também em relação ao acúmulo de $\mathrm{N}$ na planta entre os estádios de florescimento e maturação fisiológica dos grãos.

Eficiência $\mathrm{N}$ na Planta $=\frac{10 . \text { Massa da planta }}{\text { Teor } \mathrm{N} \text { na planta }}=\frac{10 \cdot \mathrm{kg}}{\frac{\mathrm{g}}{\mathrm{kg}}}=\frac{10 \cdot \mathrm{kg}^{2}}{\mathrm{~g}}$

Eficiência $\mathrm{N}$ nos Grãos $=\frac{10 . \text { Massa dos grãos }}{\text { Teor } \mathrm{N} \text { nos grãos }}=\frac{10 \cdot \mathrm{kg}}{\frac{\mathrm{g}}{\mathrm{kg}}}=\frac{10 \cdot \mathrm{kg}^{2}}{\mathrm{~g}}$

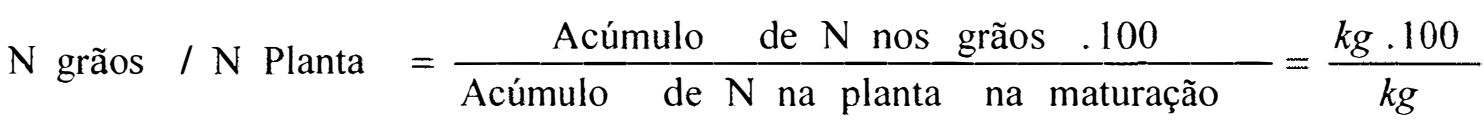

Ngrãos/Npl anta Mat - Flor $=\frac{\text { Acúmulo de } N \text { nos grãos } .100}{\text { Acúmulo de } \mathrm{N} \text { na planta na maturação - florescime nto }}=\frac{\mathrm{kg} \cdot 100}{\mathrm{~kg}}$ 
Estimou-se a eficiência agronômica do fertilizante na planta e nos grãos, considerando-se que o acumulo de $\mathrm{N}$ na planta foi proveniente apenas do fertilizante (Dwyer et al., 1995). É comum o emprego do termo recuperação aparente do $\mathrm{N}$ do fertilizante quando o cálculo da relação $\mathrm{N}$ acumulado / $\mathrm{N}$ aplicado é específico para a planta. Optouse por empregar apenas o termo eficiência agronômica do fertilizante para facilitar as comparações entre grãos e planta.

Eficiência Agronômica Planta $=\frac{\text { Acúmulo de N planta na dose } X}{\mathrm{~N} \text { fertilizan te dose } \mathrm{X}}=\frac{\frac{\mathrm{g}}{\text { planta }}}{\frac{\mathrm{g}}{\text { planta }}}$

Eficiência Agronômica Grãos $=\frac{\text { Acúmulo de } N \text { grãos na dose } X}{\mathrm{~N} \text { fertilizan te dose } \mathrm{X}}=\frac{\frac{\mathrm{g}}{\text { planta }}}{\frac{\mathrm{g}}{\text { planta }}}$

Estimou-se ainda o acúmulo relativo de matéria seca e de nitrogênio após o florescimento, expresso como percentagem do acúmulo na planta ou espiga no estádio de maturação fisiológica dos grãos.

Acúmulo Relativo Planta Mat - Flor $=\frac{\text { (Acúmulo de N na planta maturação }- \text { florescime nto) } .100}{\text { Acúmulo de N na planta maturação }}=\frac{\mathrm{kg} .100}{\mathrm{~kg}}$

Acúmulo Relativo Espigas Mat - Flor $=\frac{\text { (Acúmulode N nas espigas maturação }- \text { florescimento) } 100}{\text { Acúmulode } N \text { nas espigas maturação }}=\frac{\mathrm{kg} \cdot 100}{\mathrm{~kg}}$

Construíram-se curvas de acúmulo de matéria seca e nitrogênio no experimento de Palmital 2000/01. Coletaram-se dez plantas por tratamento, independentemente da repetição, de 15 em 15 dias a partir da emergência até os 105 dias, em 9 de março de 2001. Calculou-se a somatória térmica desses períodos considerando-se a temperatura base igual a $10^{\circ} \mathrm{C}$ e o valor da máxima em que ocorre assimilação líquida de massa na planta igual a $32^{\circ} \mathrm{C}$ (Brunini et al. 1976). As avaliações em dias corresponderam aos seguintes graus dias: $15=209,30=429,45=668,60=904,75=1150,90=1384$ e $105=1625$. As plan- 
tas inteiras foram picadas, retirando-se amostras para a determinação da massa seca e do teor de nitrogênio no tecido vegetal.

Como não houve interação entre genótipos e nitrogênio para os parâmetros acúmulo de massa seca e acúmulo de nitrogênio, analisaram-se os efeitos da adubação e das cultivares separadamente. As doses de nitrogênio ou as cultivares foram consideradas como repetições, e o delineamento foi o de blocos ao acaso (doses = blocos) no esquema de parcelas subdivididas no tempo (épocas de amostragem).

\subsection{Determinação do Nitrogênio no Solo e Tecido Vegetal}

$\mathrm{O}$ teor de $\mathrm{N}$ total nos tecidos vegetais foi determinado por destilação a vapor pelo método semi-micro Kjedahl, do extrato obtido pela digestão sulfúrica de $100 \mathrm{mg}$ de matéria seca, de acordo com Bataglia et al. (1978). O N-amoniacal e o N-nítrico do solo foram determinados por microdestilação a vapor, conforme descrito por Bremner \& Keeney (1965). O N inorgânico no solo foi extraído por solução de $\mathrm{KCl} 2 \mathrm{~mol} \mathrm{~L}^{-1}$ e destilado após a adição de $\mathrm{MgO}$ (alcaliniza o meio e converte o $\mathrm{N}_{-} \mathrm{NH}_{4}{ }^{+}$em N-NH ). O amônio foi arrastado por vapor e recolhido em solução de ácido bórico contendo uma mistura de indicadores. Em seguida, o extrato foi tratado com liga de Devarda para reduzir o $\mathrm{NO}_{3}{ }^{-} \mathrm{e}$ o $\mathrm{NO}_{2}{ }^{-}$a $\mathrm{NH}_{3}$, o qual foi também destilado por arraste de vapor e recolhido em um segundo frasco com o ácido bórico e indicadores:

\subsection{Avaliações da Qualidade Física dos Grãos}

Amostras de grãos obtidas em dois experimentos do subprojeto genótipos x nitrogênio, conduzidos em Palmital e Votuporanga no ano agrícola 2000/2001, e do experimento do subprojeto partição em Palmital em 2000/01, foram avaliadas quanto à qualidade fisica dos grãos. Os cultivares empregados no presente estudo diferem quanto à textura dos grãos, tendo-se incluído cultivares com grãos semi-dentados, semi-duros e duros (Tabela 10, Anexos 12 e 13). 
Tabela 10. Caracterização dos cultivares e relação dos experimentos em que a qualidade física dos grãos foi avaliada.

\begin{tabular}{lcccccc}
\hline \multirow{2}{*}{ Cultivar } & \multicolumn{5}{c}{ Características dos grãos } & \\
\cline { 2 - 5 } & Aparência & Duros & Cor & Oleo & Proteína & Experimento ${ }^{\text {(1) }}$ \\
\hline P 32R21 & Dentado & 20 & Amarelo & 38 & 93 & Pal-M \\
XL 212 & Dentado & 0 & Amarelo opaco & 47 & 88 & Pal-M \\
BR 3123 & Semi-dente & 90 & Amarelo/Vermelho & 52 & 88 & Vot, Pal, Pal-M \\
BR 4157 & Duro & 100 & Laranja opaco & 47 & 106 & Vot, Pal, Pal-M \\
Dina 766 & Semi-dente & 40 & Amarelo & 57 & 90 & Vot, Pal \\
84 10 & Semi-duro & 80 & Amarelo brilhante & 48 & 102 & Vot, Pal \\
CO 9560 & Semi-duro & 80 & Amarelo & 50 & 91 & Vot, Pal \\
Master & Semi-duro & 90 & Amarelo & 48 & 91 & Vot, Pal \\
Tork & Semi-duro & 90 & Amarelo & 49 & 92 & Vot, Pal \\
XL 251 & Semi-duro & 75 & Amarelo & 51 & 93 & Vot, Pal \\
AG 1051 & Dentado & 15 & Laranja opaco & 58 & 88 & Pal, PalM \\
C 333B & Semi-duro & 60 & Amarelo & 53 & 103 & Pal \\
\end{tabular}

(1) Pal-M refere-se a Palmital colhido na maturação, Pal e Vot correspondem a Palmital e Votuporanga colhidos com umidade dos grãos inferior a $27 \%$.

As parcelas foram colhidas manualmente quando a cultivar mais tardia apresentava menos de $27 \%$ de umidade, e debulhadas mecanicamente, exceto as do suprojeto partição em Palmital. Nesse experimento, as espigas foram colhidas na maturidade fisiológica dos grãos e debulhadas manualmente depois de secagem ao ar, sendo denominadas Palmital-Maturação (Palm-Mat).

Os grãos provenientes dos dois experimentos do subprojeto genótipos x nitrogênio foram armazenados em câmara fria $\mathrm{a}-4^{\circ} \mathrm{C}$, e os do suprojeto partição foram refrigerados a $16^{\circ} \mathrm{C}$. Em maio de 2002 os grãos foram enviados para a Universidade de Nebraska Lincoln, onde se avaliaram parâmetros de qualidade física. Amostras sem impurezas e grãos quebrados, peneiradas em malha de $5 \mathrm{~mm}$ e apresentando baixa umidade (Palm- 
Mat $=11,0$ a 12,0\% e Votuporanga e Palmital $=10,0$ a 11,0\%), foram deixadas em contato com o ar ambiente para equilibrar a umidade.

A determinação da massa de um volume conhecido de grãos ("Test weight") foi realizada em aparelho Dickey-John (Modelo GAC II, Dickey John Corp., Auburn, IL, USA). A suscetibilidade ao quebramento foi avaliada empregando o "Wisconsin Breakage Susceptibility Test", de acordo com os procedimentos descritos por Paulsen and Hill (1985). A percentagem de quebramento foi calculada a partir da massa da fração que permaneceu na peneira de $5,6 \mathrm{~mm}$. Foi determinada a percentagem de grãos flutuantes quando imersos em solução de nitrato de sódio $31,3^{\circ}$ Baumè a $60^{\circ} \mathrm{C}$, correspondendo à massa específica de 1,276 (Peplinski et al., 1989). A densidade específica foi avaliada utilizando-se picnômetro em comparação com ar (Wu and Bergquist, 1991). Determinou-se a dureza dos grãos pelos métodos "Tangential Abrasive Dehulling Device" (TADD) e "Stenvert Hardness Test" (Anexos 14 e 15). A percentagem de perda pelo método TADD foi calculada depois de se submeter $20 \mathrm{~g}$ de grãos à abrasão durante 10 minutos e remover o material desprendido (Reichart et al., 1986). No "Stenvert Hardness Test", $20 \mathrm{~g}$ de milho foram moídas utilizando moinho de micro-martelos com peneira de $2 \mathrm{~mm}$ e rotação de $3600 \mathrm{rpm}$. Foram avaliados o tempo para a moagem e a altura do material moído em tubo de coleta (Pomeranz et al., 1985).

\subsection{Análise Estatística}

Empregou-se o programa estatístico SANEST para as análises de variância dos resultados agronômicos nos três subprojetos, e o programa estatístico SAS (SAS, 1989). para as análises agronômicas conjuntas no subprojeto genótipos x nitrogênio e para todas as análises de $\mathrm{N}$ inorgânico no solo e de qualidade física dos grãos.

Nos subprojetos Parcelamento e Partição, o efeito doses de nitrogênio sobre o teor de $\mathrm{N}$ inorgânico, $\mathrm{N}_{-} \mathrm{NH}_{4}{ }^{+}$e $\mathrm{N}-\mathrm{NO}_{3}{ }^{-}$no solo foi estudado por contrastes ortogonais. No subprojeto Parcelamento os contrastes foram os seguintes: testemunha $\mathrm{x}$ adubado, dose $60 \mathrm{~kg} \mathrm{ha}^{-1} \mathrm{x}$ dose $240 \mathrm{~kg} \mathrm{ha}^{-1}$, ( 0 na base +60 em cobertura) $\mathrm{x}(60$ na base +0 em cobertura), (60 na base +180 em cobertura) x (120 na base + 120 em cobertura). Já no sub- 
projeto Partição, os contrastes foram específicos para a adubação de cobertura: testemunha $\mathrm{x}$ adubado, dose $60 \mathrm{~kg} \mathrm{ha}^{-1} \mathrm{x}$ (dose 120 e $180 \mathrm{~kg} \mathrm{ha}^{-1}$ ), dose $120 \mathrm{~kg} \mathrm{ha}^{-1} \mathrm{x}$ dose 180 $\mathrm{kg} \mathrm{ha}^{-1}$. Os contrastes ortogonais também foram empregados para o estudo do efeito profundidade, comparando-se a camada mais superficial $(0-10 \mathrm{~cm}$ ou $10-20 \mathrm{~cm}) \times$ demais e a 20-40 $\mathrm{cm} \times$ 40-60 cm. Apenas em Votuporanga 1998/99, onde a camada 0-20 $\mathrm{cm}$ foi subdividida em 0-10 e 10-20 cm, comparou-se também a camada 10-20 cm x (20-40 e 40-60 cm). Desdobou-se o efeito profundidade em cada dose, mesmo que a interação tratamento x profundidade não foi significativa.

No estudo dos parâmetros agronômicos dos subprojetos genótipos $\mathrm{x}$ nitrogênio $\mathrm{e}$ partição, comparou-se o efeito de cultivares pelo teste Tukey $5 \%$, e o efeito das doses de nitrogênio, por meio de regressão polinomial. No subprojeto parcelamento, os tratamentos doses de nitrogênio foram comparados por contrastes ortogonais (Tabela 11).

No estudo da curva de acúmulo, as cultivares foram estudadas através de contrastes ortogonais, comparando-se: tropicais (AG 1051, BR 3123 e BRS 4157) x temperadas (DKB 212 e P 32R21), AG 1051 x (BR 3123 e BRS 4157), BR $3123 \times$ BRS 4157 e DKB $212 \times \mathrm{P} 32 \mathrm{R} 21$. Devido à massa seca da parte aérea ter sido muito pequena aos 15 dias após a semeadura, desconsiderou-se esta época nas análises de variância. Como alguns nutrientes e cultivares apresentaram valores de acúmulo aos 105 dias inferiores aos obtidos aos 90 dias, desconsiderou-se também essa época na análise de variância do acúmulo para evitar possíveis interferências das perdas nos resultados. O efeito de épocas foi avaliado por meio de regressão polinomial. Além dessas análises, procedeu-se a análise de variância do acúmulo de matéria seca e nitrogênio considerando-se todas as épocas, para construir curvas de acúmulo para cultivares e doses de nitrogênio.

As análises de qualidade fĩsica dos grãos foram realizadas em duplicata, calculando-se as médias para as análises estatisticas. Procedeu-se a análise de variância de cada experimento e a análise conjunta de Palmital e Votuporanga utilizando-se oito cultivares comuns. O efeito das doses foi estudadado por regressão polinomial. Como a interação $\mathrm{N} x$ cultivar foi desprezível para quase todos os parâmetros avaliados, optou-se por apresentar apenas os efeitos das doses de nitrogênio sobre a qualidade dos grãos. 
Tabela 11. Contrastes ortogonais referentes ao subprojeto parcelamento da adubação nitrogenada em cultivares de milho

\begin{tabular}{ll}
\hline Contraste & \multicolumn{1}{c}{ Modelo } \\
\hline N240 x demais & $(\mathrm{T} 8+\mathrm{T} 9) \times(\mathrm{T} 1+\mathrm{T} 1 "+\mathrm{T} 2+\mathrm{T} 3+\mathrm{T} 4+\mathrm{T} 5+\mathrm{T} 6+\mathrm{T} 7)$ \\
Dentro de N240 & $\mathrm{T} 8 \times \mathrm{T} 9$ \\
$\mathrm{~N}$ somente em cobertura $\mathrm{x}$ & $(\mathrm{T} 1+\mathrm{T} 2+\mathrm{T} 3+\mathrm{T} 4) \times(\mathrm{T} 1$ " $+\mathrm{T} 5+\mathrm{T} 6+\mathrm{T} 7)$ \\
$(60 \mathrm{~N}$ base + Ncobertura $)$ & \\
$\begin{array}{l}\text { Dentro de N somente em cobertura } \\
\text { Dentro de }(60 \mathrm{~N} \text { base }+\mathrm{N} \text { cobertura })\end{array}$ & Regressão polinomial $(0,60,120$ e $180 \mathrm{de} \mathrm{N})$ \\
\hline
\end{tabular}

(1) Tratamentos mencionados no Quadro 3 


\section{RESULTADOS E DISCUSSÃO}

\subsection{Nitrogênio no Solo}

Nas amostragens realizadas no momento da semeadura, houve grande variabilidade nos resultados de $\mathrm{N}$ inorgânico entre os locais e gradiente de $\mathrm{N}$ inorgânico entre as camadas $0-20$ e $20-40 \mathrm{~cm}$ para a maioria dos solos (Tabela 12). Os menores valores foram encontrados em Itapeva 1998/99 e Votuporanga 1999/2000. Os latossolos roxos de Palmital e Cândido Mota apresentaram os maiores teores de $\mathrm{N}$ inorgânico e predominância de nitrato em relação ao amônio no solo original. Esse maior teor de nitrato no solo continuou na testemunha durante o desenvolvimento da cultura apenas em Palmital 00/01 (Figuras 9 a 23 e Tabelas 13 a 17). Provavelmente a ausência de gradiente de $\mathrm{N}$ nas camadas do solo no tratamento testemunha seja devida ao fato de as plantas absorverem nitrogênio principalmente da camada superficial do solo, onde se concentra a maior parte do sistema radicular.

Comparando as condições ambientais e os valores de $\mathrm{N}$ no solo nas amostragens realizadas durante o desenvolvimento da cultura, verifica-se que os valores de $\mathrm{N}$ inorgânico na segunda amostragem foram muito baixos quando os excessos hídricos foram significativos. É o caso de Cândido Mota e Votuporanga em 1998/99 e Votuporanga em 1999/00. Em Votuporanga 1998/99 não se evidenciou mais o efeito de tratamento na segunda amostragem, e os teores de $\mathrm{N}$ inorgânico foram baixos na primeira amostragem mesmo nos tratamento onde se aplicaram $120+60 \mathrm{~kg} \mathrm{ha}^{-1}$ de $\mathrm{N}$ (base $+1^{a}$ cobertura). Isso se deve, provavelmente, ao solo arenoso, ao uso da irrigação, ao emprego contínuo de gramíneas na área nos dois anos que antecederam o experimento e ao crescimento de plantas de aveia preta nas entrelinhas do milho, 
Tabela 12. Teores de nitrogênio inorgânico no solo por ocasião da semeadura do milho nos experimentos de adubação

\begin{tabular}{|c|c|c|c|c|c|c|c|}
\hline \multirow[t]{2}{*}{ Local } & \multirow[t]{2}{*}{ Ano } & \multicolumn{2}{|c|}{$0-20 \mathrm{~cm}$} & \multicolumn{2}{|c|}{$20-40 \mathrm{~cm}$} & \multicolumn{2}{|c|}{$40-60 \mathrm{~cm}$} \\
\hline & & $\mathrm{N}-\mathrm{NH}_{4}^{+}$ & $\mathrm{N}-\mathrm{NO}_{-3}$ & $\mathrm{~N}-\mathrm{NH}_{4}{ }^{+}$ & $\mathrm{N}-\mathrm{NO}_{-3}$ & $\mathrm{~N}-\mathrm{NH}_{4}{ }^{+}$ & $\mathrm{N}-\mathrm{NO}_{-3}$ \\
\hline & & $\ldots \ldots \ldots \ldots \ldots$ & ............. & $\mu \mathrm{g} \mathrm{g}^{-1} .$. & 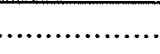 & …....... & \\
\hline Votuporanga ${ }^{(1)}$ & $98 / 99$ & 6,48 & 4,27 & 4,49 & 1,38 & 3,24 & 2,90 \\
\hline Cândido Mota (1) & $98 / 99$ & 4,07 & 7,69 & 3,53 & 8,59 & 2,90 & 10,63 \\
\hline Itapeva $\mathrm{N} \times \mathrm{G}$ & $98 / 99$ & 2,70 & 2,70 & 3,09 & 3,09 & - & - \\
\hline Votuporanga $^{(1)}$ & $99 / 00$ & 2,41 & 2,41 & 2,07 & - 2,76 & - & - \\
\hline Palmital ${ }^{(1)}$ & $99 / 00$ & 2,59 & 6,21 & 1,55 & 4,14 & - & - \\
\hline Votuporanga $\mathrm{NxG}$ & $00 / 01$ & - & - & - & - & - & - \\
\hline Palmital Partição & $00 / 01$ & 4,11 & 6,46 & 2,94 & 9,1 & 2,35 & 6,46 \\
\hline Palmital NxG & $00 / 01$ & 2,93 & 5,52 & 1,55 & 2,07 & - & - \\
\hline
\end{tabular}

(I) Experimentos dos diferentes subprojetos em áreas adjacentes

aumentando a demanda pelo nitrogênio do solo.

Comparando-se os resultados das Figuras 9 e 10 entre si, nota-se que em Votuporanga em 1998/99 predominou a forma de $\mathrm{N}$-amônio nas duas épocas de amostragem, em quase todos os casos. Como já mencionado, as quantidades de amônio e nitrato encontradas no solo nas duas amostragens realizadas no experimento de Votuporanga em 1998/99 foram baixas, não atingindo $8 \mu \mathrm{g} \mathrm{g}^{-1}$. Esse fato ocorreu independentemente da dose e da época de aplicação do nitrogênio. Como a primeira amostragem foi feita cerca de 35 dias depois da adubação de semeadura, constata-se que, mesmo nesse curto espaço de tempo, o nutriente aplicado havia sido totalmente absorvido pela cultura, imobilizado pelos microrganismos do solo ou lixiviado. 

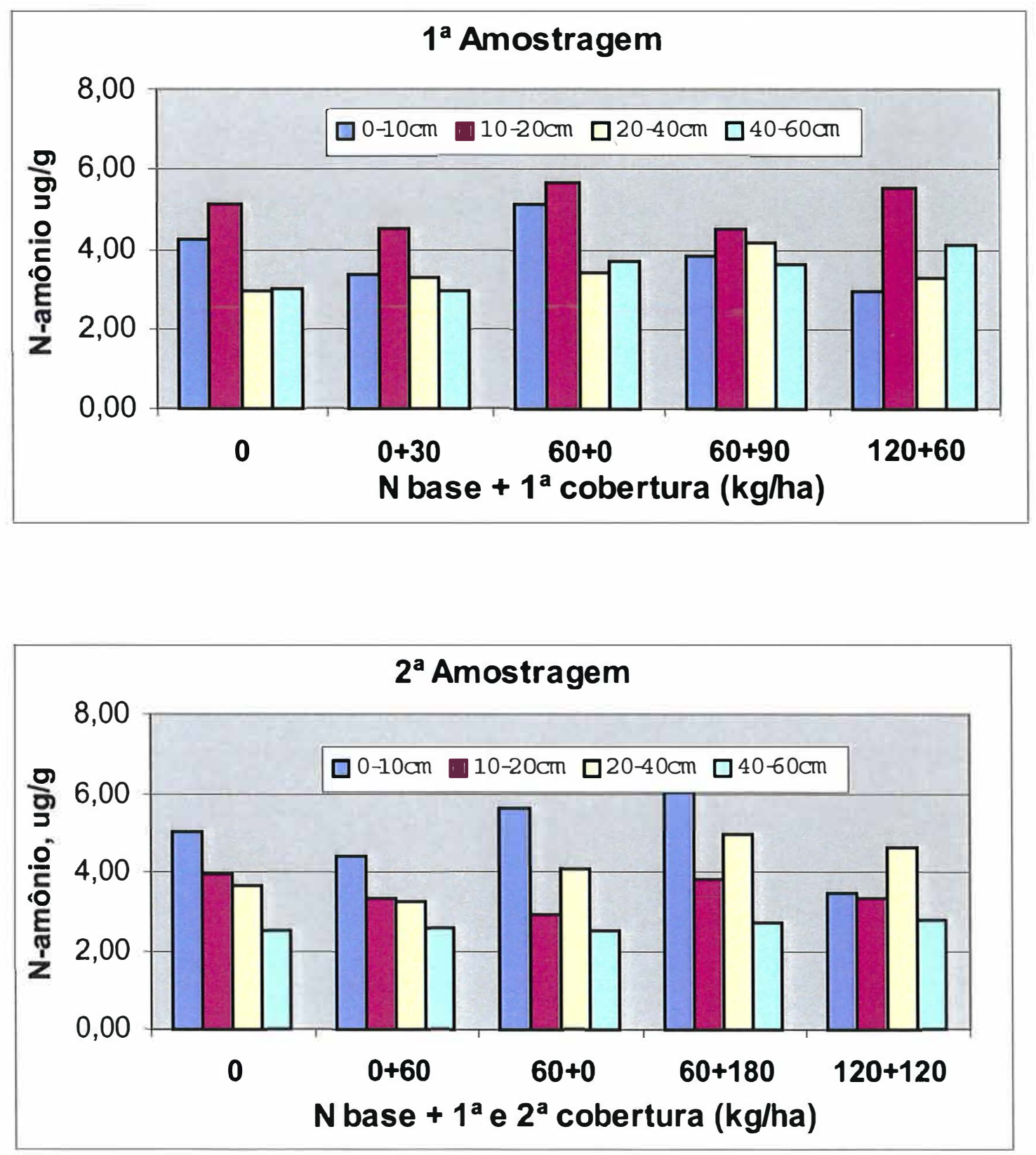

Figura 9- Teor de $\mathrm{N}_{-} \mathrm{NH}_{4}{ }^{+}$em amostras de solo retiradas em diferentes profundidades, imediatamente antes da segunda cobertura e após o florescimento, no subprojeto "Resposta de Genótipos de Milho ao Parcelamento e Doses de Nitrogênio", realizado em Votuporanga em 1998/99 

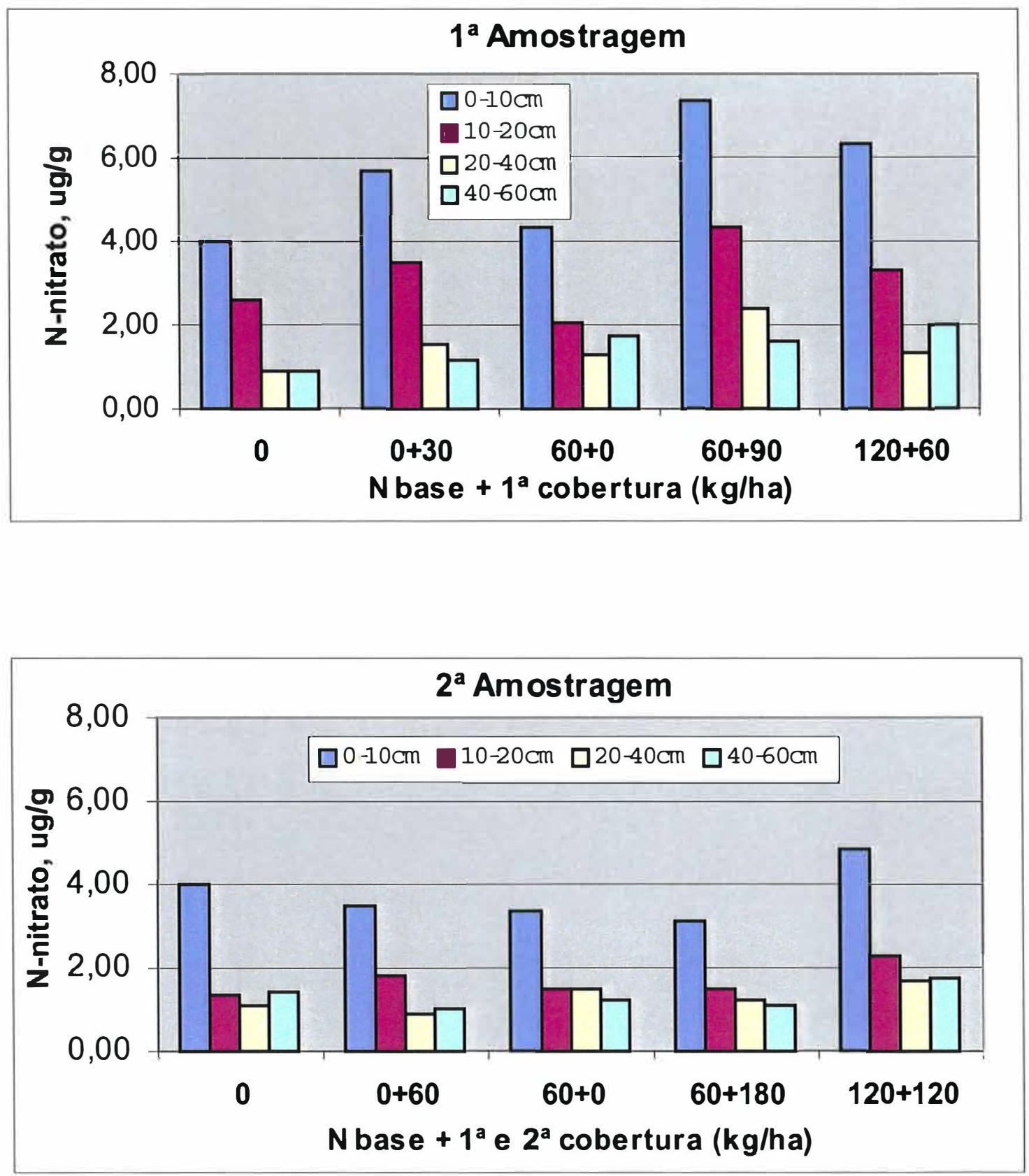

Figura 10- Teor de $\mathrm{N}-\mathrm{NO}_{3}{ }^{-}$em amostras de solo retiradas em diferentes profundidades imediatamente antes da segunda cobertura e após o florescimento, no subprojeto "Resposta de Genótipos de Milho ao Parcelamento e Doses de Nitrogênio", realizado em Votuporanga em 1998/99 

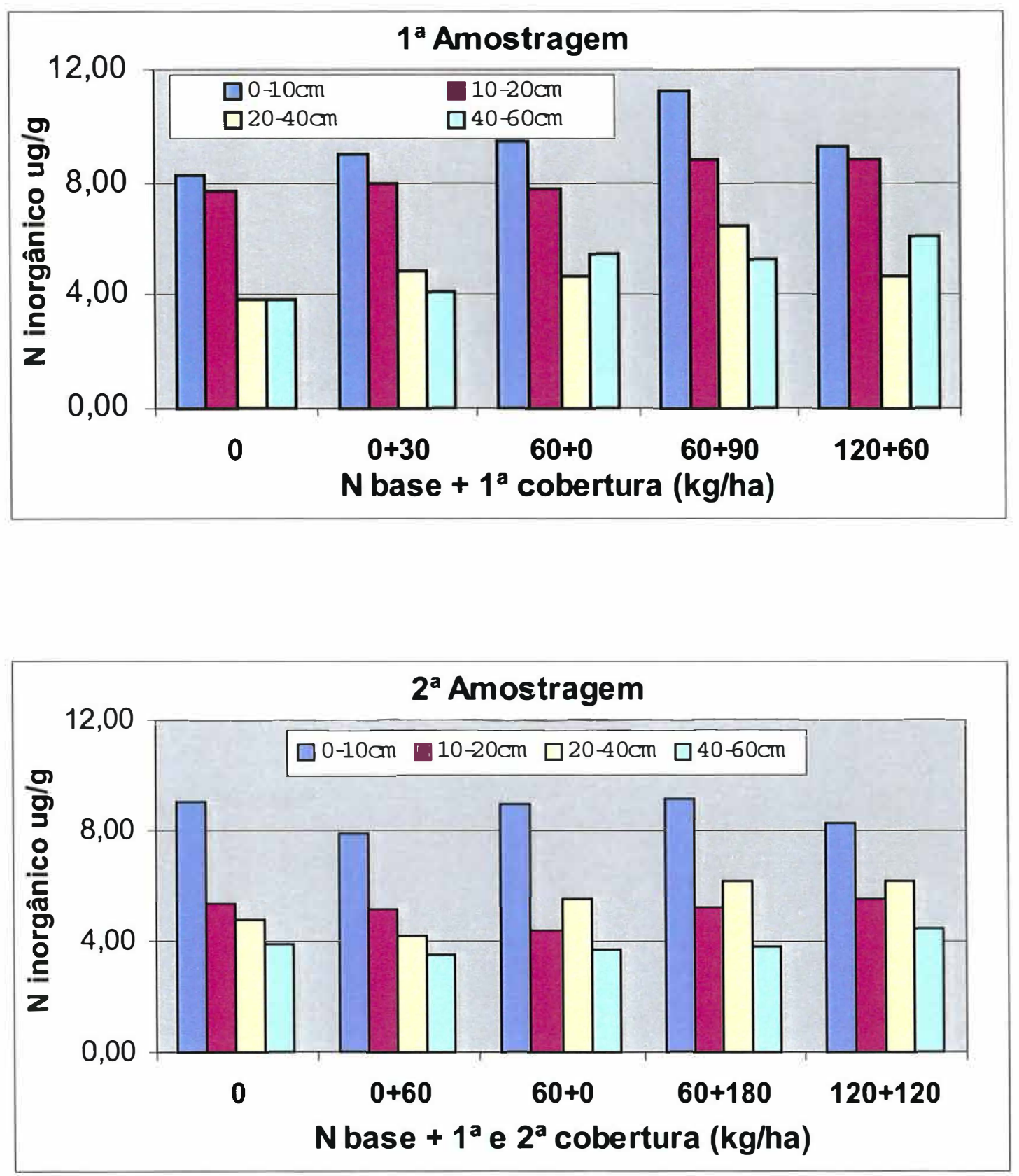

Figura 11- Teor de nitrogênio inorgânico $\left(\mathrm{N}_{-} \mathrm{NO}_{3}{ }^{-}+\mathrm{N}_{-} \mathrm{NH}_{4}{ }^{+}\right)$em amostras de solo retiradas em diferentes profundidades imediatamente antes da segunda cobertura e após o florescimento, no subprojeto "Resposta de Genótipos de Milho ao Parcelamento e Doses de Nitrogênio", realizado em Votuporanga em 1998/99 

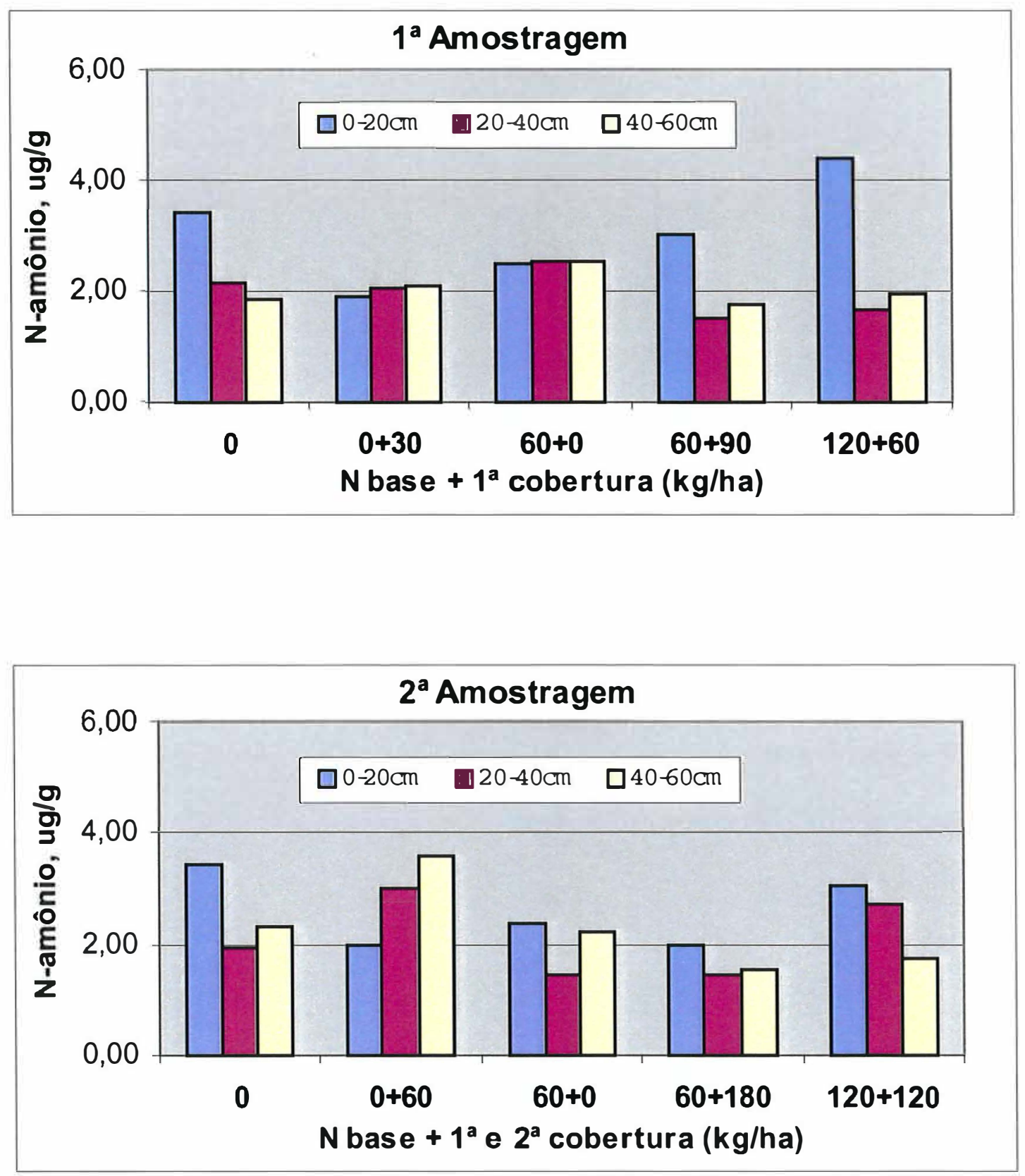

Figura 12- Teor de $\mathrm{N}-\mathrm{NH}_{4}{ }^{+}$em amostras de solo retiradas em diferentes profundidades imediatamente antes da segunda cobertura e após o florescimento, no subprojeto "Resposta de Genótipos de Milho ao Parcelamento e Doses de Nitrogênio", realizado em Cândido Mota em 1998/99 

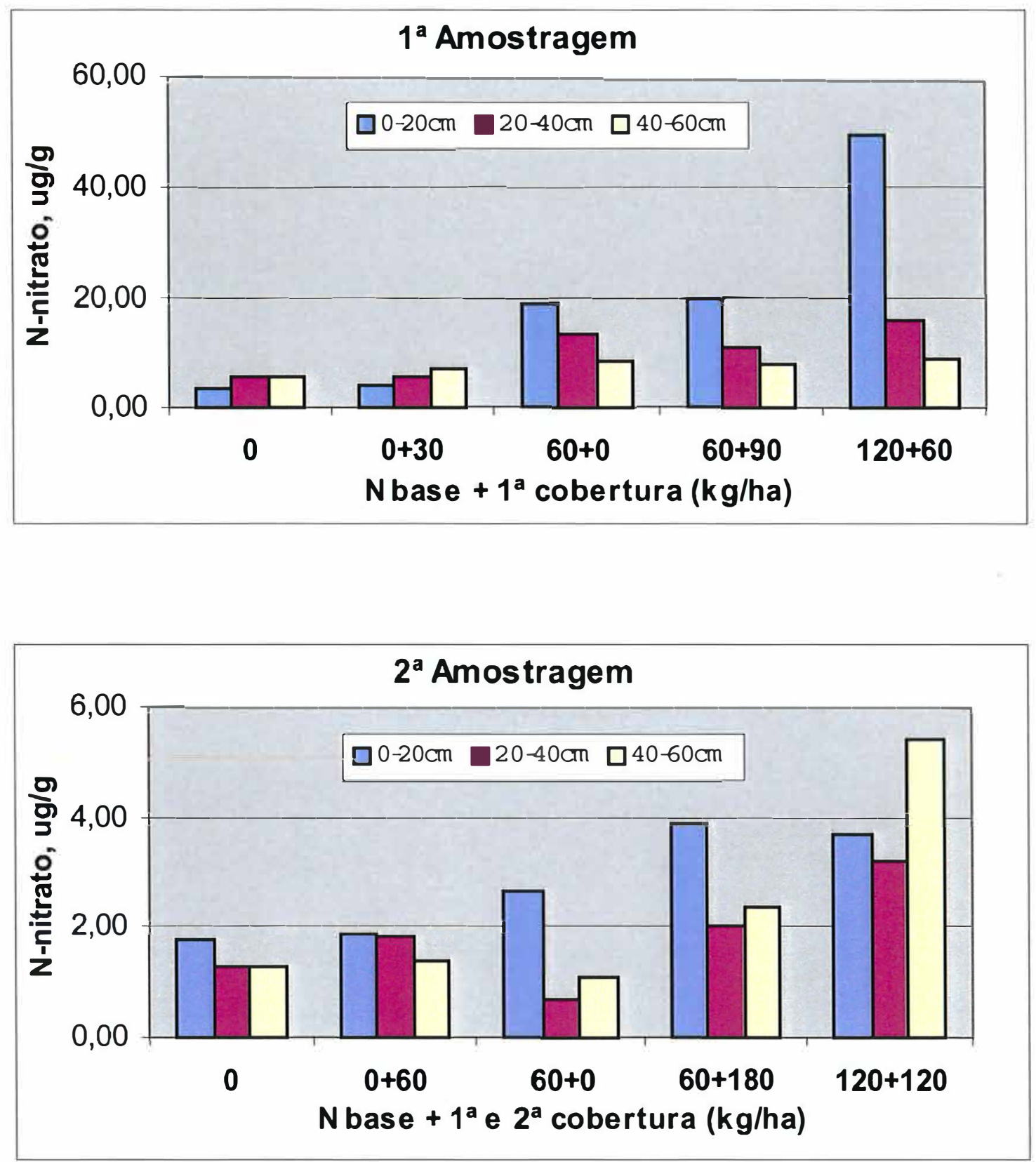

Figura 13- Teor de $\mathrm{N}-\mathrm{NO}_{3}{ }^{-}$em amostras de solo retiradas em diferentes profundidades imediatamente antes da segunda cobertura e após o florescimento, no subprojeto "Resposta de Genótipos de Milho ao Parcelamento e Doses de Nitrogênio", realizado em Cândido Mota em 1998/99 

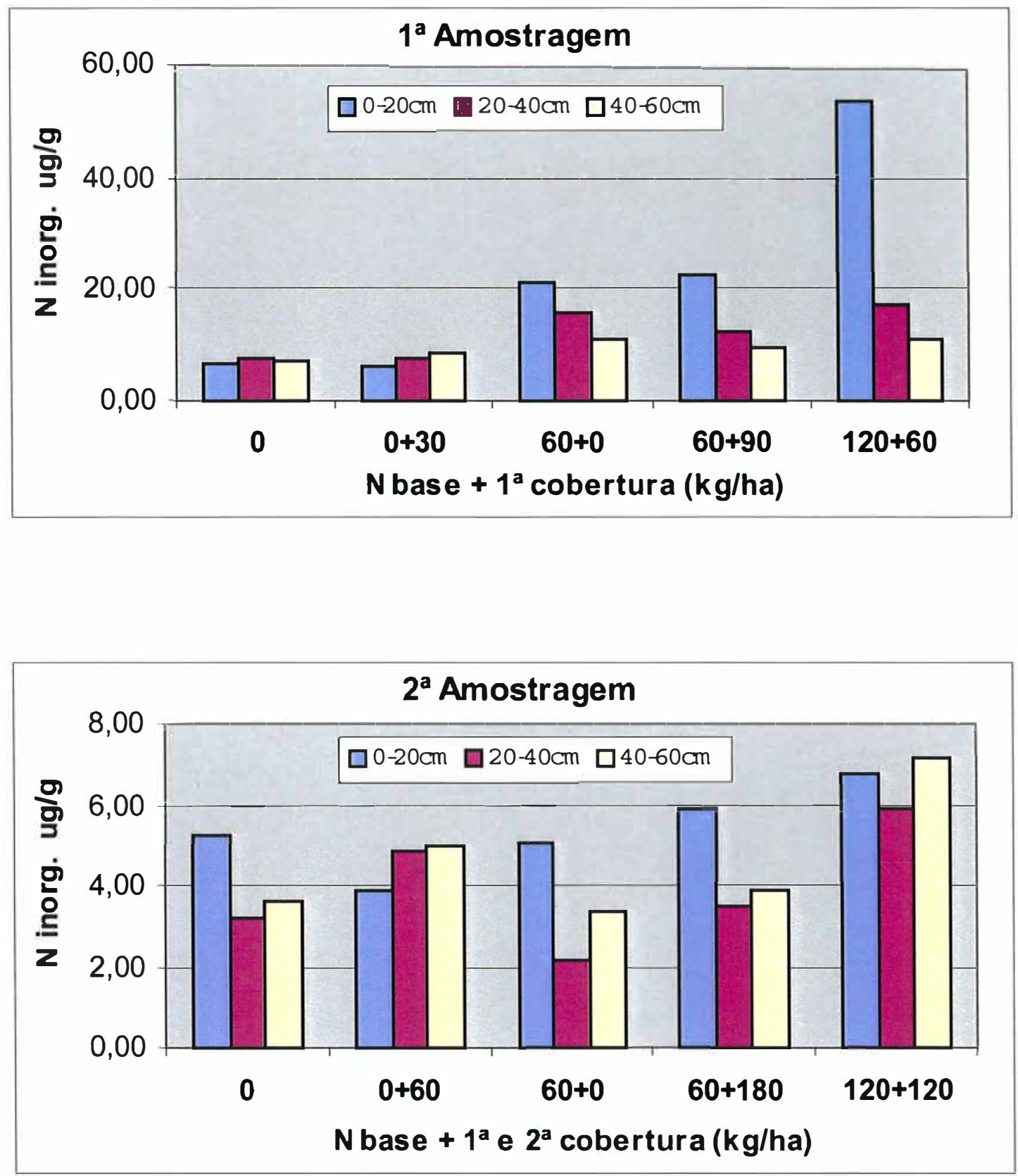

Figura 14- Teor de nitrogênio inorgânico $\left(\mathrm{N}_{-} \mathrm{NO}_{3}{ }^{-}+\mathrm{N}^{-} \mathrm{NH}_{4}{ }^{+}\right)$em amostras de solo retiradas em diferentes profundidades imediatamente antes da segunda cobertura e após o florescimento, no subprojeto "Resposta de Genótipos de Milho ao Parcelamento e Doses de Nitrogênio", realizado em Cândido Mota em 1998/99 

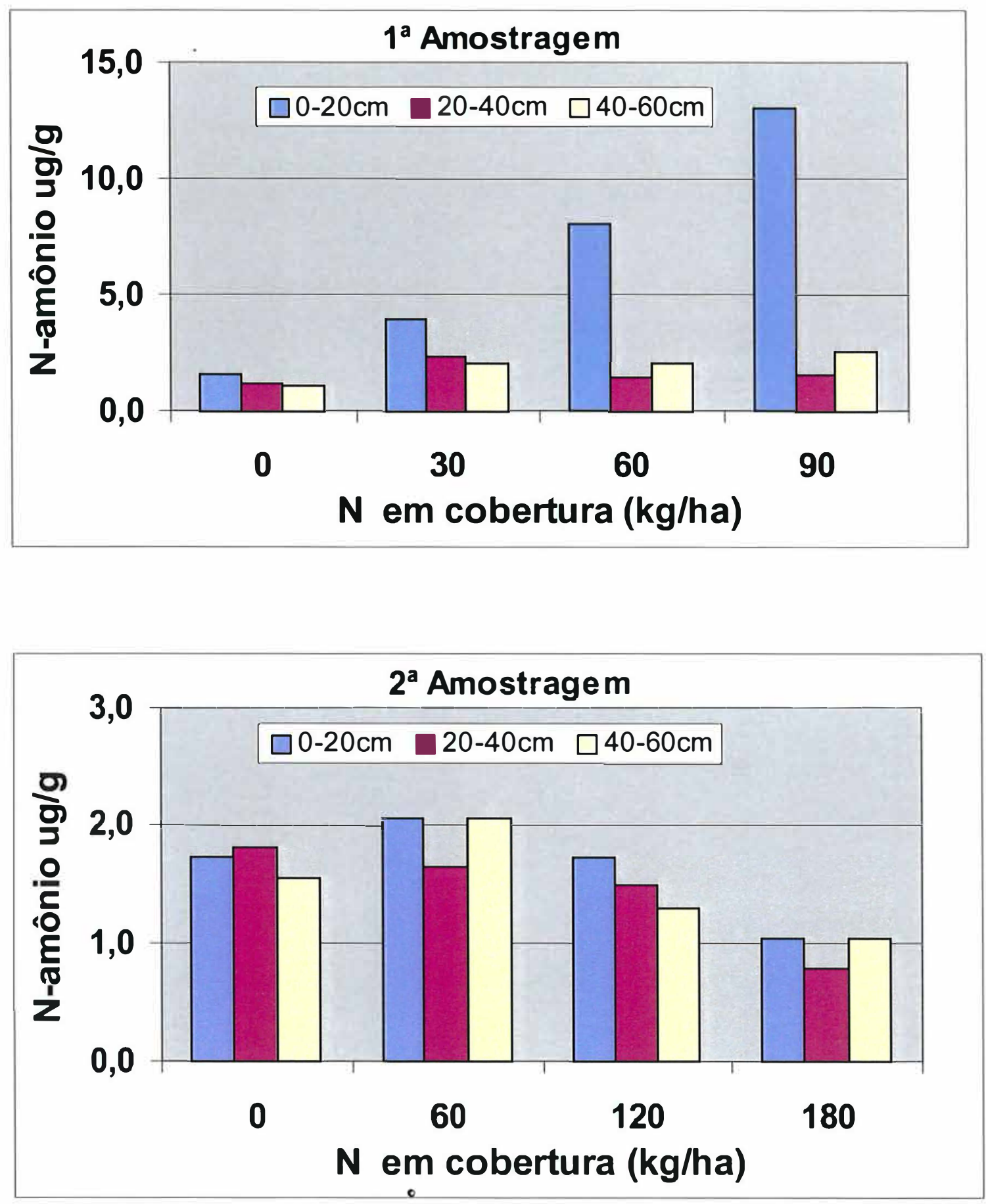

Figura 15- Teor de $\mathrm{N}-\mathrm{NH}_{4}{ }^{+}$em amostras de solo retiradas em diferentes profundidades, imediatamente antes da segunda cobertura e cerca de 20 dias após o florescimento, no subprojeto "Acúmulo e Partição do Nitrogênio em Genótipos de Milho", realizado em Votuporanga em 1999/2000. 

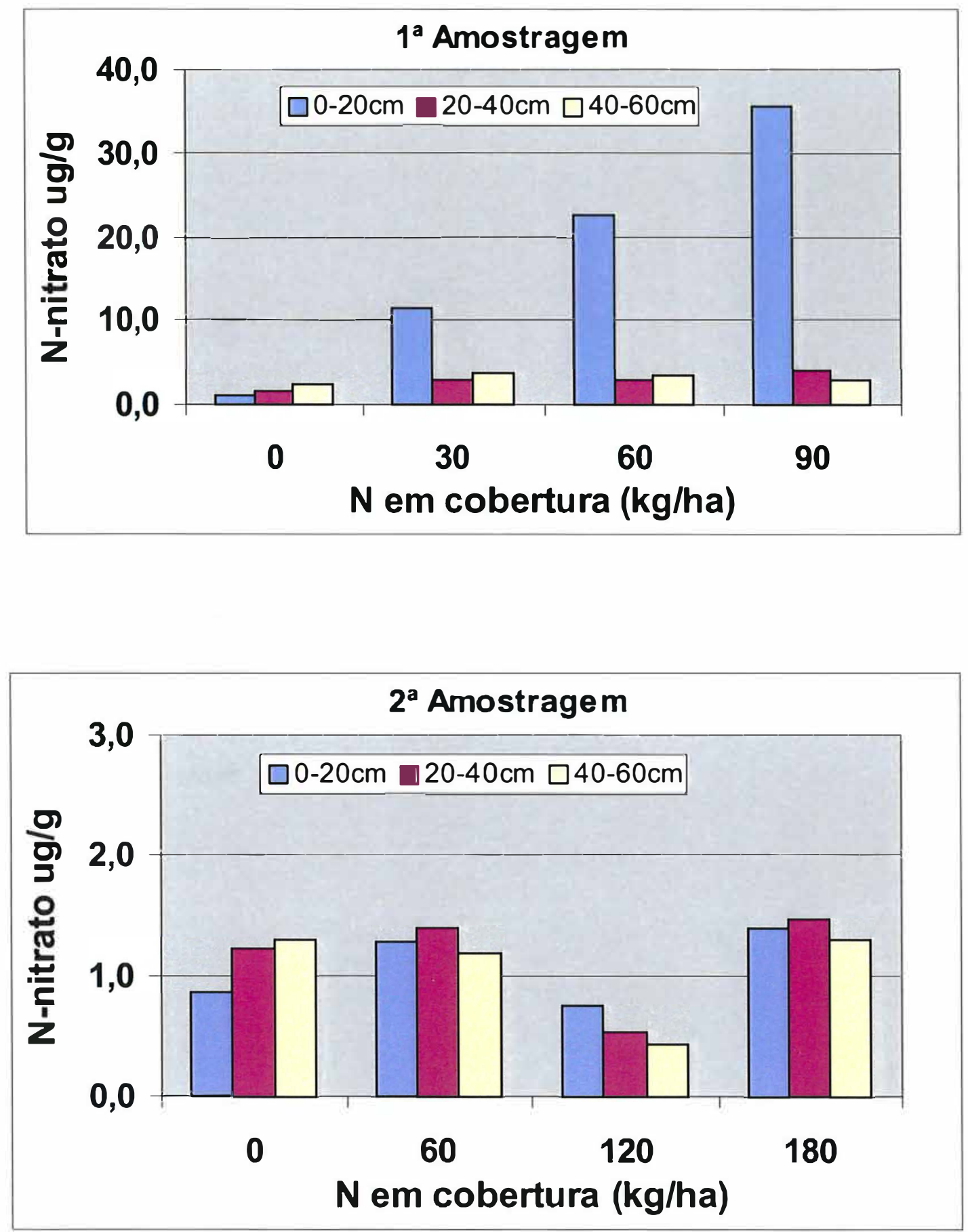

Figura 16- Teor de $\mathrm{N}_{-} \mathrm{NO}_{3}{ }^{-}$em amostras de solo retiradas em diferentes profundidades imediatamente antes da segunda cobertura e cerca de 20 dias após o florescimento, no subprojeto "Acúmulo e Partição do Nitrogênio em Genótipos de Milho", realizado em Votuporanga em 1999/2000. 

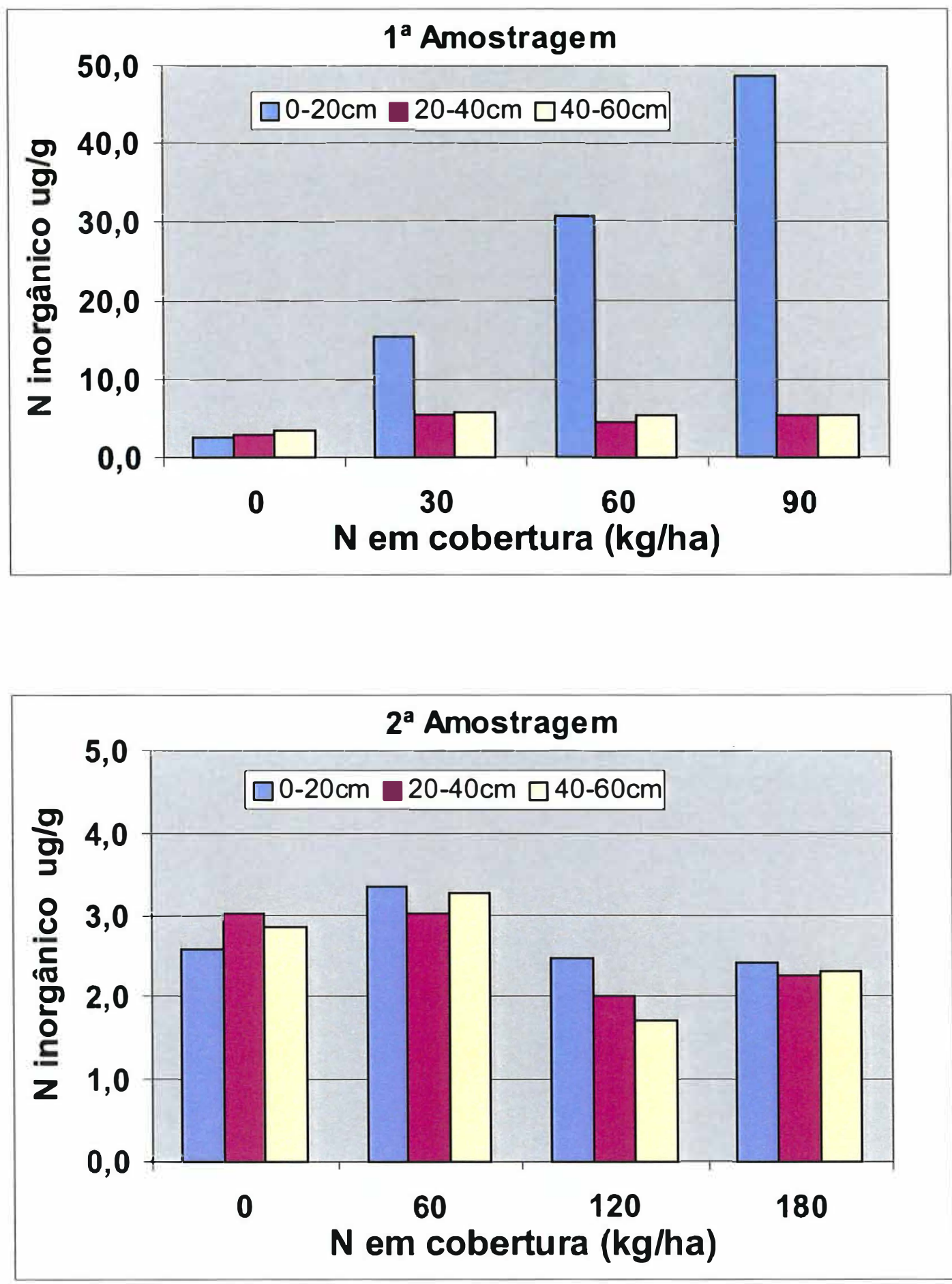

Figura 17- Teor de nitrogênio inorgânico $\left(\mathrm{N}^{-N_{3}}{ }^{-}+\mathrm{N}^{-} \mathrm{NH}_{4}{ }^{+}\right)$em amostras de solo retiradas em diferentes profundidades imediatamente antes da segunda cobertura e cerca de 20 dias após o florescimento, no subprojeto "Acúmulo e Partição do Nitrogênio em Genótipos de Milho", realizado em Votuporanga em 1999/2000. 

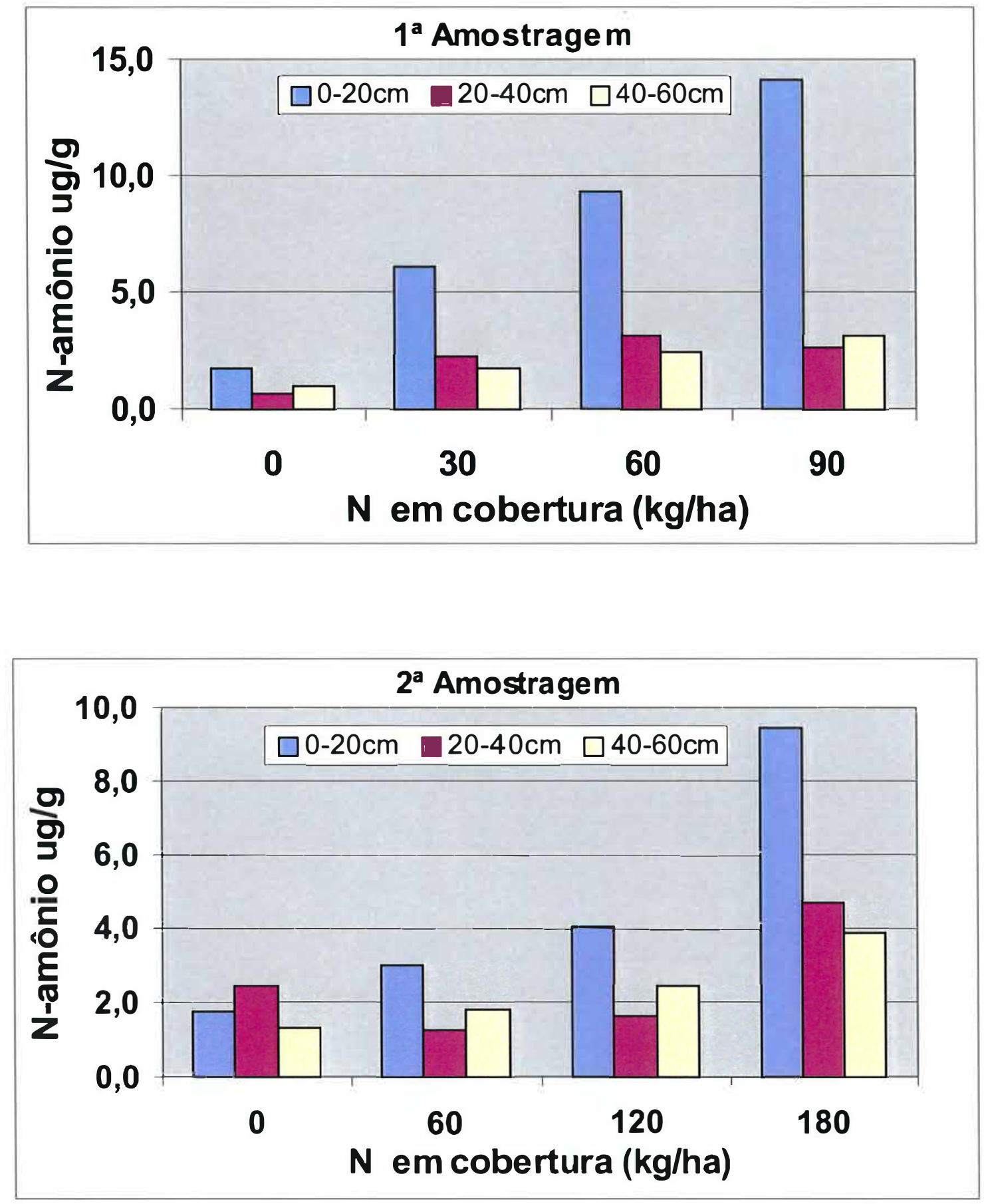

Figura 18- Teor de $\mathrm{N}-\mathrm{NH}_{4}{ }^{+}$em amostras de solo retiradas em diferentes profundidades, imediatamente antes da segunda cobertura e após o florescimento, no subprojeto "Acúmulo e Partição do Nitrogênio em Genótipos de Milho", realizado em Palmital em 1999/2000. 

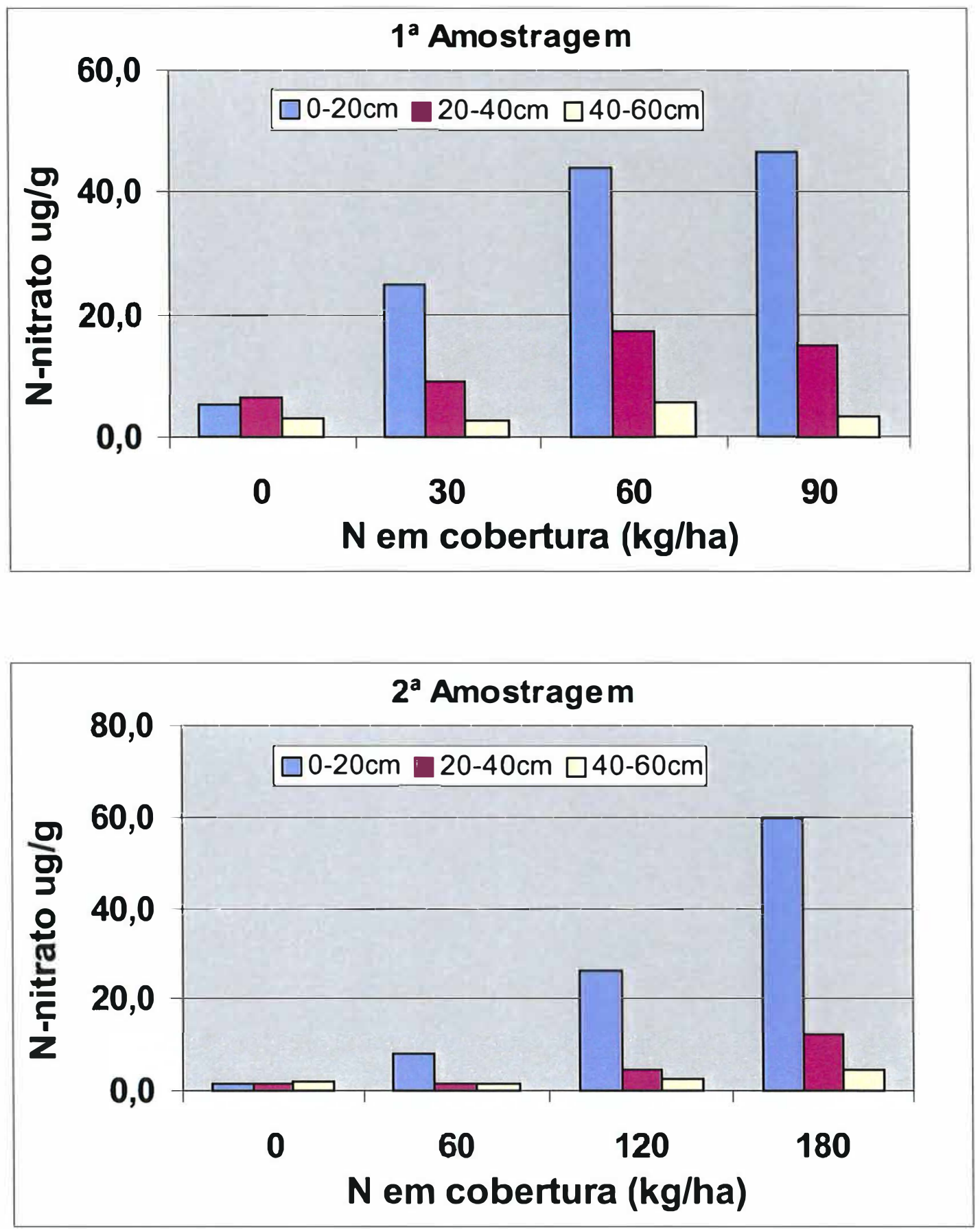

Figura 19- Teor de $\mathrm{N}_{-} \mathrm{NO}_{3}{ }^{-}$em amostras de solo retiradas em diferentes profundidades imediatamente antes da segunda cobertura e após o florescimento, no subprojeto "Acúmulo e Partição do Nitrogênio em Genótipos de Milho", realizado em Palmital em 1999/2000. 

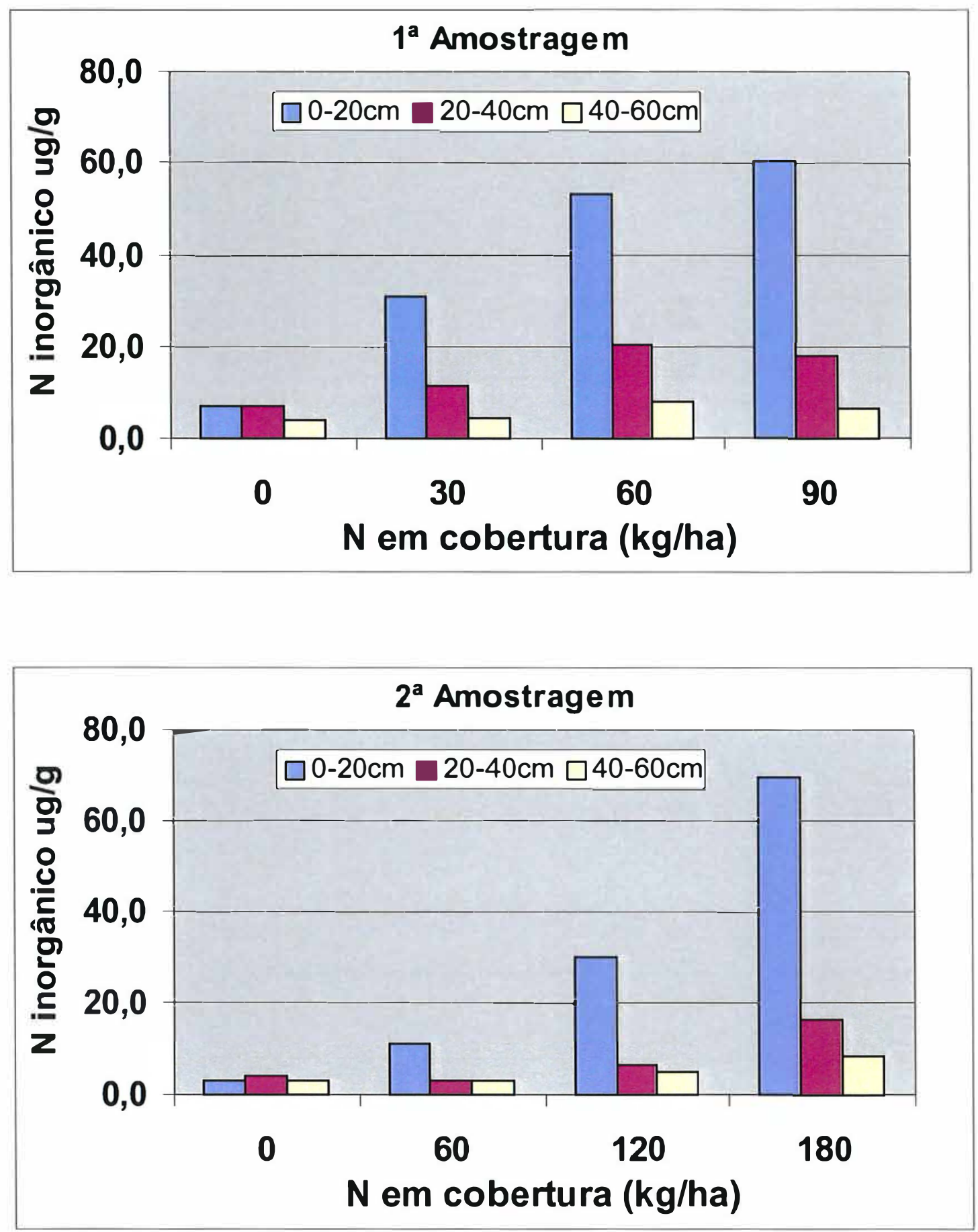

Figura 20- Teor de nitrogênio inorgânico $\left(\mathrm{N}_{-} \mathrm{NO}_{3}{ }^{-}+\mathrm{N}_{-} \mathrm{NH}_{4}{ }^{+}\right)$em amostras de solo retiradas em diferentes profundidades imediatamente antes da segunda cobertura e após o florescimento, no subprojeto "Acúmulo e Partição do Nitrogênio em Genótipos de Milho", realizado em Palmital em 1999/2000. 

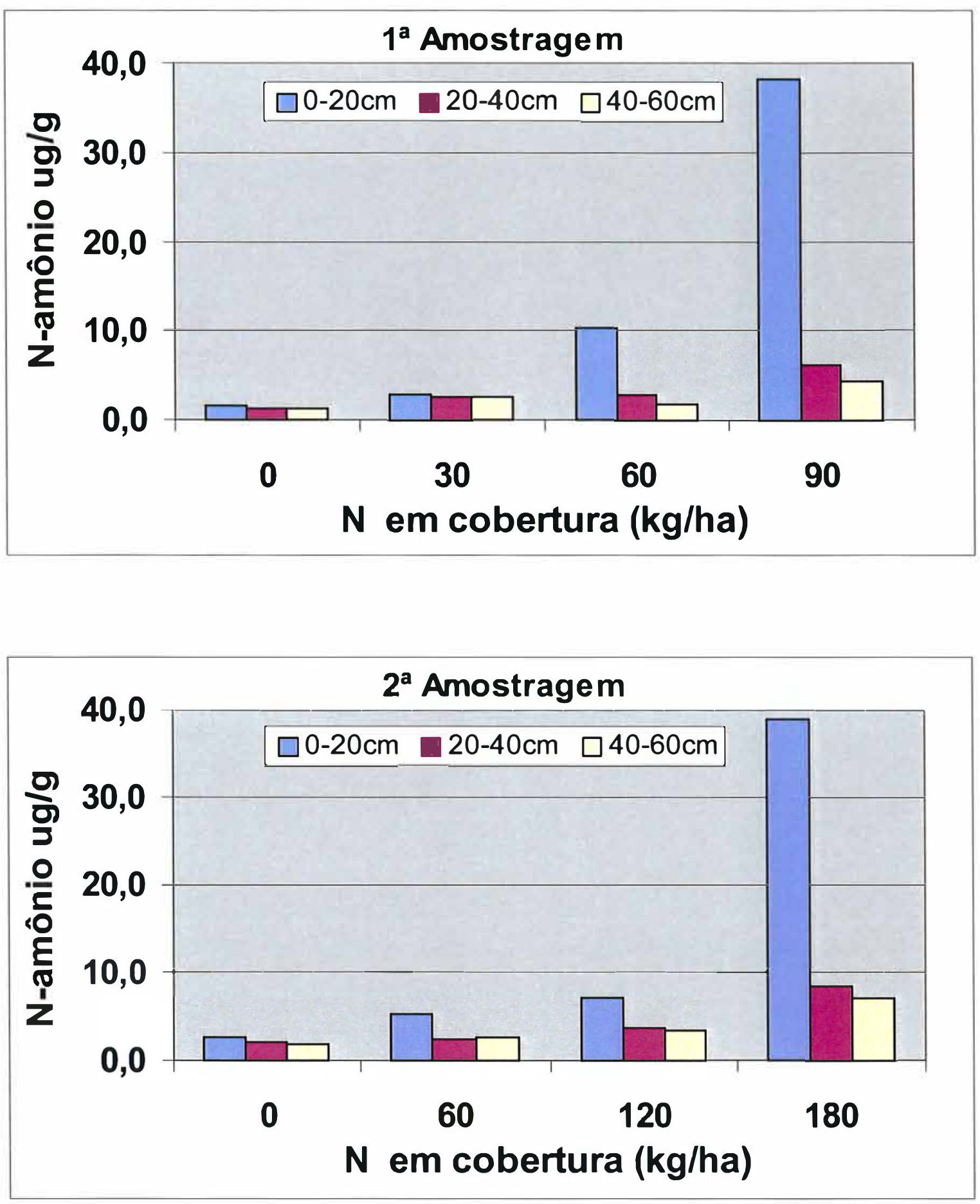

Figura 21 - Teor de $\mathrm{N}-\mathrm{NH}_{4}{ }^{+}$em amostras de solo retiradas em diferentes profundidades, imediatamente antes da segunda cobertura e do florescimento, no subprojeto "Acúmulo e Partição do Nitrogênio em Genótipos de Milho", realizado em Palmital 2000/2001. 

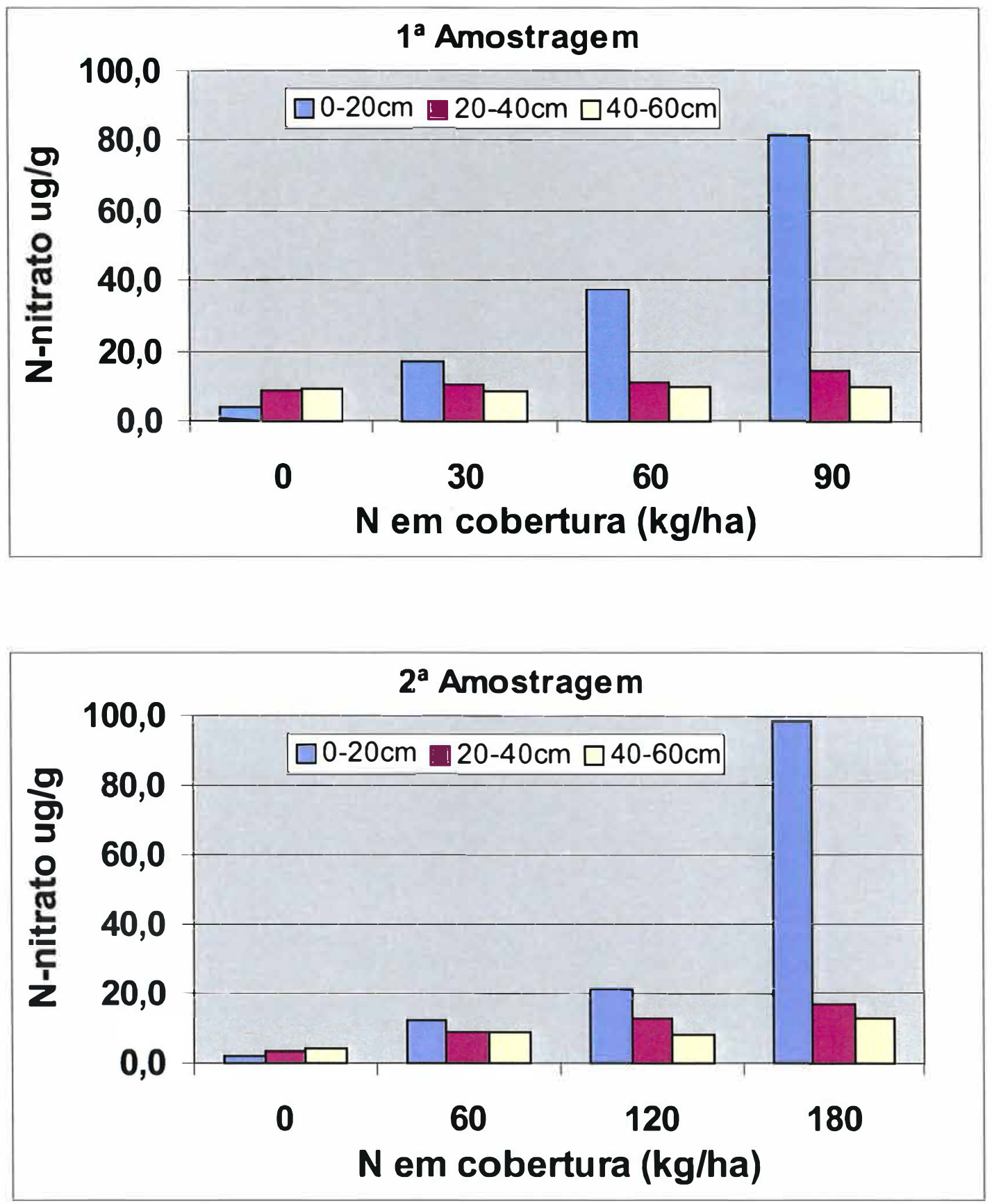

Figura 22- Teor de $\mathrm{N}-\mathrm{NO}_{3}{ }^{-}$em amostras de solo retiradas em diferentes profundidades imediatamente antes da segunda cobertura e do florescimento, no subprojeto "Acúmulo e Partição do Nitrogênio em Genótipos de Milho", realizado em Palmital 2000/2001. 

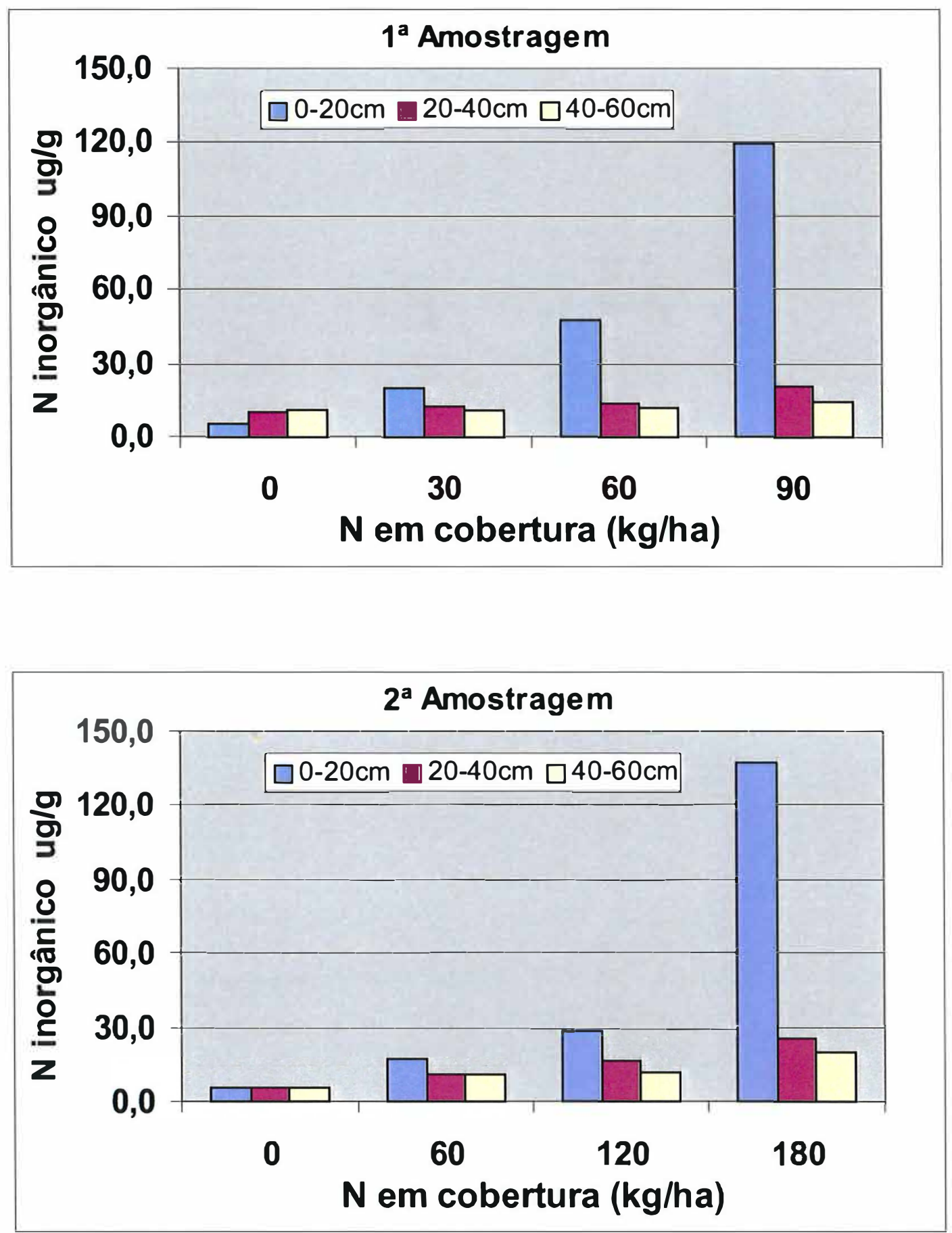

Figura 23- Teor de nitrogênio inorgânico $\left(\mathrm{N}_{-} \mathrm{NO}_{3}{ }^{-}+\mathrm{N}_{-} \mathrm{NH}_{4}{ }^{+}\right)$em amostras de solo retiradas em diferentes profundidades imediatamente antes da primeira e da segunda cobertura e do florescimento, no subprojeto "Acúmulo e Partição do Nitrogênio em Genótipos de Milho", realizado em Palmital 2000/2001 
Já em Votuporanga 1990/00, onde os teores de $\mathrm{N}$ na camada 0-20 cm aumentaram de maneira mais expressiva com a adubação nitrogenada, na primeira amostragem predominou nitrato na camada superficial, exceto na testemunha (Figuras 15 e 16). Na segunda amostragem prevaleceu o nitrogênio na forma de amônio, exceto na dose $180 \mathrm{~kg} \mathrm{ha}^{-1} \mathrm{em}$ todas as profundidades.

No experimento em Cândido Mota, mesmo nas parcelas adubadas, as quantidades de $\mathrm{N}$-amoniacal foram igualmente baixas em ambas as épocas de amostragem (Figura 12), mas as de $\mathrm{N}$-nitrato foram da ordem de 20 a $50 \mu \mathrm{g} \mathrm{g}^{-1}$ na primeira amostragem (realizada imediatamente antes da segunda cobertura e cerca de 50 dias após a semeadura), nas parcelas que receberam nitrogênio (Figura 13). Na primeira amostragem os teores de nitrato foram aparentemente maiores do que os de amônio nas parcelas com 60 e $120 \mathrm{~kg} \mathrm{ha}^{-1}$ de $\mathrm{N}$ no sulco de semeadura, enquanto na ausência de adubação nitrogenada, os valores de nitrato e amônio foram semelhantes. Isso mostra que nessa época o amônio aplicado já havia sido totalmente nitrificado, imobilizado ou absorvido pela cultura, mas ainda havia um pequeno resíduo da adubação na forma nítrica. Na segunda época de amostragem, contudo, esse resíduo não estava mais presente no solo, pois as concentrações de $\mathrm{N}$ inorgânico caíram para menos de $6 \mu \mathrm{g} \mathrm{g}^{-1} \mathrm{e}$ igualaram-se à da testemunha.

Em Palmital em 1999/00 e 2000/01, na primeira amostragem predominou o nitrato em todos os tratamentos e profundidades (Figuras 18 a 23). Na segunda amostragem em 2000/01, o nitrato também predominou, menos na camada 0-20 cm da testemunha. Já na segunda amostragem realizada em 1999/00, os valores de nitrato sobressaíram-se em relação ao amônio apenas na dose $60 \mathrm{~kg} \mathrm{ha}^{-1}$, na camada 0-20 cm, e nas doses 120 e $180 \mathrm{~kg} \mathrm{ha}^{-1}$, nas camadas $0-20$ e $20-40 \mathrm{~cm}$.

Ao comparar o efeito da adubação nitrogenada em relação à testemunha (Tabelas 14 a 17), verifica-se que em Votuporanga (1998/99 e 1999/00), em solo textura média, as diferenças foram significativas apenas na primeira amostragem. Em Votuporanga 1998/99, N-nitrato e N inorgânico diferiram entre as parcelas adubadas e a testemunha, enquanto em Votuporanga 1999/00 diferiram o N-amônio, N-nitrato e N inorgânico. Em Cândido Mota (1998/99) e Palmital (1999/00 e 2000/01), em solo muito argiloso, a 
Tabela 13. Teste F, média e coeficiente de variação da análise de variância do nitrogênio inorgânico no solo nos tratamentos doses e modos de aplicação da adubação nitrogenada, na base e em cobertura, em amostras retiradas em diferentes profundidades em Votuporanga 1998/99 ${ }^{(1)}$.

\section{$\mathrm{NH}_{4}{ }^{+} \quad \mathrm{NO}_{3}^{-} \quad \mathrm{N}$ total}

Fatores da variação $\quad 1^{\mathrm{a}}$ Época $2^{\mathrm{a}}$ Época $1^{\mathrm{a}}$ Época $2^{\mathrm{a}}$ Época $1^{\mathrm{a}}$ Época $2^{\mathrm{a}}$ Época

\begin{tabular}{|c|c|c|c|c|c|c|}
\hline \multirow[b]{2}{*}{ Tratamento $^{(2)}$} & \multicolumn{6}{|c|}{$\mathrm{P}>\mathrm{F}$} \\
\hline & $* *$ & Ns & $* *$ & $*$ & $*$ & $\mathrm{Ns}$ \\
\hline Testemunha $\mathrm{x}$ adubado & Ns & Ns & $* *$ & Ns & $* *$ & Ns \\
\hline Dose $60 \times$ Dose 240 & Ns & Ns & $*$ & Ns & $*$ & Ns \\
\hline$(0+60) \times(60+0)$ & $* *$ & Ns & Ns & Ns & Ns & Ns \\
\hline$(60+180) \times(120+120)$ & Ns & Ns & Ns & $* *$ & Ns & Ns \\
\hline Profundidade, $\mathrm{cm}$ & $* *$ & $* *$ & $* *$ & $* *$ & $* *$ & $* *$ \\
\hline $0-10 \times$ demais & Ns & $* *$ & $* *$ & $* *$ & $* *$ & $* *$ \\
\hline $10-20 \times(20-40$ e $40-60)$ & $* *$ & Ns & $* *$ & $* *$ & $* *$ & $* *$ \\
\hline $20-40 \times 40-60$ & Ns & $* *$ & Ns & Ns & Ns & $* *$ \\
\hline TratamentoxProfundidade & $* *$ & $*$ & Ns & Ns & Ns & Ns \\
\hline Dose 0 & $* *$ & $* *$ & $* *$ & $* *$ & $* *$ & $* *$ \\
\hline Dose $0+60$ & $* *$ & $* *$ & $* *$ & $* *$ & $* *$ & $* *$ \\
\hline Dose $60+0$ & $* *$ & $* *$ & $* *$ & $* *$ & $* *$ & $* *$ \\
\hline Dose $60+180$ & Ns & $* *$ & $* *$ & $* *$ & $* *$ & $* *$ \\
\hline Dose $120+120$ & $* *$ & $* *$ & $* *$ & $* *$ & $* *$ & $* *$ \\
\hline Bloco & Ns & $* *$ & Ns & $* *$ & Ns & $* *$ \\
\hline Média $\left(\mu g g^{-1}\right)$ & 4,0 & 3,8 & 2,9 & 2,0 & 6,9 & 5,8 \\
\hline C. V. (\%) & 6,8 & 9,7 & 19,1 & 11,2 & 9,1 & 7,7 \\
\hline
\end{tabular}

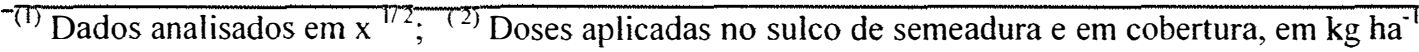


Tabela 14. Teste F, média e coeficiente de variação da análise de variância do nitrogênio inorgânico no solo nos tratamentos doses e modos de aplicação da adubação nitrogenada, na base e em cobertura, em amostras retiradas em diferentes profundidades em Cândido Mota 1998/99 (1).

$$
\mathrm{NH}_{4}^{+} \mathrm{NO}_{3}^{-} \quad \mathrm{N} \text { total }
$$

Fatores da variação $\quad 1^{\mathrm{a}}$ Época $2^{\mathrm{a}}$ Época $1^{\mathrm{a}}$ Época $2^{\mathrm{a}}$ Época $1^{\mathrm{a}}$ Época $2^{\mathrm{a}}$ Época

\begin{tabular}{|c|c|c|c|c|c|c|}
\hline \multirow[b]{2}{*}{ Tratamento ${ }^{(2)}$} & \multicolumn{6}{|c|}{$\mathrm{P}>\mathrm{F}$} \\
\hline & $\mathrm{Ns}$ & $* *$ & $* *$ & $* *$ & $* *$ & $* *$ \\
\hline Testemunha $\mathrm{x}$ adubado & Ns & Ns & $* *$ & $*$ & $* *$ & Ns \\
\hline Dose $60 \mathrm{x}$ Dose 240 & Ns & $*$ & $* *$ & $* *$ & $* *$ & $* *$ \\
\hline$(0+60) \times(60+0)$ & Ns & $* *$ & $* *$ & Ns & $* *$ & $*$ \\
\hline$(60+180) \times(120+120)$ & Ns & $* *$ & $* *$ & $*$ & $* *$ & $* *$ \\
\hline Profundidade, $\mathrm{cm}$ & $*$ & Ns & $* *$ & $* *$ & $* *$ & $*$ \\
\hline $0-20 \times(20-40$ e $40-60)$ & $* *$ & Ns & $* *$ & $* *$ & $* *$ & $* *$ \\
\hline $20-40 \times 40-60$ & Ns & Ns & Ns & Ns & Ns & Ns \\
\hline TratamentoxProfundidade & Ns & Ns & $* *$ & * & $* *$ & Ns \\
\hline Dose 0 & Ns & Ns & Ns & Ns & Ns & Ns \\
\hline Dose $0+60$ & Ns & Ns & Ns & Ns & Ns & Ns \\
\hline Dose $60+0$ & Ns & Ns & $*$ & $* *$ & $*$ & $*$ \\
\hline Dose $60+180$ & Ns & Ns & $*$ & $* *$ & $* *$ & Ns \\
\hline Dose $120+120$ & $* *$ & Ns & $* *$ & $* *$ & $* *$ & Ns \\
\hline Bloco & Ns & Ns & Ns & Ns & Ns & Ns \\
\hline Média $\left(\mu \mathrm{g} \mathrm{g}^{-1}\right)$ & 2,3 & 2,3 & 12,3 & 1,3 & 14,6 & 4,6 \\
\hline C. V. (\%) & 20,9 & 22,4 & 18,5 & 16,3 & 16,8 & 14,2 \\
\hline
\end{tabular}

(7) Dados analisados em $x^{1 / 2}$; (2) Doses aplicadas no sulco de semeadura e em cobertura, em kg ha 
Tabela 15. Teste F, média e coeficiente de variação da análise de variância do nitrogênio inorgânico no solo em função da adubação nitrogenada de cobertura e da profundidade de amostragem em Votuporanga 1999/2000 ${ }^{(1)}$.

$\mathrm{NH}_{4}^{+} \quad \mathrm{NO}_{3}^{-} \quad \mathrm{N}$ total

Fatores da variação

$1^{\mathrm{a}}$ Época $2^{\mathrm{a}}$ Época $1^{\mathrm{a}}$ Época $2^{\mathrm{a}}$ Época $1^{\mathrm{a}}$ Época $2^{\mathrm{a}}$ Época

\begin{tabular}{|c|c|c|c|c|c|c|}
\hline \multirow[b]{2}{*}{ Tratamento } & \multicolumn{6}{|c|}{$\mathrm{P}>\mathrm{F}$} \\
\hline & $* *$ & $* *$ & $* *$ & $* *$ & $* *$ & $* *$ \\
\hline Testemunha $\mathrm{x}$ adubado & ** & Ns & ** & Ns & $* *$ & Ns \\
\hline Dose $60 \times$ (Dose 120 e 180$)$ & $*$ & $* *$ & $* *$ & Ns & $* *$ & $* *$ \\
\hline Dose $120 \times$ Dose 180 & $* *$ & $* *$ & Ns & $* *$ & $* *$ & Ns \\
\hline Profundidade, $\mathrm{cm}$ & $* *$ & Ns & $* *$ & Ns & $* *$ & Ns \\
\hline $0-20 \times(20-40$ a $40-60)$ & $* *$ & Ns & $* *$ & Ns & $* *$ & Ns \\
\hline $20-40 \times 40-60$ & Ns & Ns & Ns & Ns & Ns & Ns \\
\hline Tratamento x Profundidade & $* *$ & Ns & $* *$ & Ns & $* *$ & Ns \\
\hline Dose 0 & Ns & Ns & Ns & Ns & Ns & Ns \\
\hline Dose 60 & Ns & Ns & $* *$ & Ns & $* *$ & Ns \\
\hline Dose 120 & $* *$ & Ns & $* *$ & $*$ & $* *$ & $*$ \\
\hline Dose 180 & $* *$ & Ns & $* *$ & Ns & $* *$ & Ns \\
\hline Bloco & Ns & Ns & Ns & $* *$ & Ns & $*$ \\
\hline Média $\left(\mu g \mathrm{~g}^{-1}\right)$ & 3,4 & 1,5 & 7,9 & 1,1 & 11,3 & 2,6 \\
\hline C. V. $(\%)$ & 20,0 & 12,8 & 16,1 & 11,5 & 12,6 & 8,9 \\
\hline
\end{tabular}

(1) Dados analisados em x ${ }^{1 / 2}$; 25 Doses aplicadas em cobertura, em kg ha ${ }^{-1}$ 
Tabela 16. Teste F, média e coeficiente de variação da análise de variância do nitrogênio inorgânico no solo em função da adubação nitrogenada de cobertura e da profundidade de amostragem em Palmital 1999/2000 ${ }^{(1)}$.

\begin{tabular}{|c|c|c|c|c|c|c|}
\hline \multirow[b]{2}{*}{ Fatores da variação } & \multicolumn{2}{|c|}{$\mathrm{NH}_{4}^{+}$} & \multicolumn{2}{|c|}{$\mathrm{NO}_{3}^{-}$} & \multicolumn{2}{|c|}{$\mathrm{N}$ total } \\
\hline & $1^{\mathrm{a}}$ Época & ${ }^{a}$ Época & $1^{\text {a Época }}$ & Época 1 & ${ }^{a}$ Época & $2^{\mathrm{a}}$ Época \\
\hline & & & $\mathrm{P}=$ & & & \\
\hline Tratamento ${ }^{(2)}$ & $* *$ & $* *$ & $* *$ & $* *$ & $* *$ & $* *$ \\
\hline Testemunha $\mathrm{x}$ adubado & $* *$ & $* *$ & $* *$ & $* *$ & $* *$ & $* *$ \\
\hline Dose $60 \times$ (Dose 120 e 180$)$ & $* *$ & $* *$ & $* *$ & $* *$ & $* *$ & $* *$ \\
\hline Dose $120 \times$ Dose 180 & Ns & $* *$ & Ns & $* *$ & Ns & $* *$ \\
\hline Profundidade, $\mathrm{cm}$ & $* *$ & $* *$ & $* *$ & $* *$ & $* *$ & $* *$ \\
\hline $0-20 \times(20-40$ a $40-60)$ & $* *$ & $* *$ & $* *$ & $* *$ & $* *$ & $* *$ \\
\hline $20-40 \times 40-60$ & Ns & Ns & $* *$ & $* *$ & $* *$ & $*$ \\
\hline Tratamento $\mathrm{x}$ Profundidade & $* *$ & $* *$ & $* *$ & $* *$ & $* *$ & $* *$ \\
\hline Dose 0 & Ns & Ns & * & Ns & * & Ns \\
\hline Dose 60 & $* *$ & $*$ & $* *$ & $* *$ & $* *$ & $* *$ \\
\hline Dose 120 & $* *$ & $* *$ & $* *$ & $* *$ & $* *$ & $* *$ \\
\hline Dose 180 & $* *$ & $* *$ & $* *$ & $* *$ & $* *$ & $* *$ \\
\hline Bloco & Ns & Ns & Ns & Ns & Ns & Ns \\
\hline Média $\left(\mu g g^{-1}\right)$ & 4,0 & 3,1 & 15,2 & 10,5 & 19,2 & 13,6 \\
\hline C. V. $(\%)$ & 17,1 & 15,8 & 11,0 & 20,0 & 8,8 & 15,1 \\
\hline
\end{tabular}

${ }^{(1)}$ Dados analisados em $\mathrm{x}{ }^{1 / 2}$; ${ }^{27}$ Doses aplicadas em cobertura, em kg ha 
Tabela 17. Teste F, média e coeficiente de variação da análise de variância do nitrogênio inorgânico no solo em função da adubação nitrogenada de cobertura e da profundidade de amostragem em Palmital 2000/01 ${ }^{(1)}$.

$\mathrm{NH}_{4}^{+} \quad \mathrm{NO}_{3}^{-} \quad \mathrm{N}$ total

Fatores da variação

$1^{\mathrm{a}}$ Época $2^{\mathrm{a}}$ Época $1^{\mathrm{a}}$ Época $2^{\mathrm{a}}$ Época $1^{\mathrm{a}}$ Época $2^{\mathrm{a}}$ Época

Tratamento ${ }^{(2)}$

Testemunha $\mathrm{x}$ adubado

Dose $60 \mathrm{x}$ (Dose $120 \mathrm{e} 180$ )

Dose $120 \times$ Dose 180

Profundidade, $\mathrm{cm}$

$0-20 \times(20-40$ a $40-60)$

$20-40 \times 40-60$

$\mathrm{P}>\mathrm{F}$

Tratamento x Profundidade

Dose 0

Dose 60

Dose 120

Dose 180

Bloco

Ns

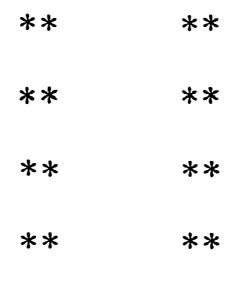

$* *$

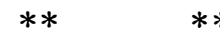

**

$* *$

$* *$

$* *$

$* *$

$* *$

$* *$

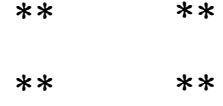

$* *$

$* *$

$* *$

$* *$

$* *$

$* *$

$* *$

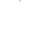

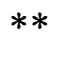

$* *$

$* *$

$* *$

**

Ns

Ns

Ns

$* *$

$* *$
$* *$

$* *$

Ns

**

** $\quad * *$

Ns

*

Ns

Ns

$* *$

$* *$

Ns

Ns

Ns

Ns

$* *$

Ns

**

*

Ns

$* *$

Ns

**

$* *$

$* *$

$* *$

$* *$

**

$* *$

$* * \quad * *$

$* *$

Ns

Ns

Média $\left(\mu \mathrm{g} \mathrm{g}^{-1}\right)$

6,3

7,

18,5

$17,4 \quad 24,8$

24,5

C. V. $(\%)$

$13,6 \quad 18,1$

9,2

13,1

8,0

12,4

${ }^{\text {(1) }}$ Dados analisados em $x^{1 / 2}$; ${ }^{(2)}$ Doses aplicadas em cobertura, em kg ha 
forma $\mathrm{N}$-nitrato foi maior nas parcelas adubadas do que na testemunha nas duas amostragens. Apenas em Palmital (1999/00 e 2000/01) a forma N-amônio e o N inorgânico também aumentaram nas parcelas adubadas em relação à testemunha nas duas amostragens. Os valores de $\mathrm{N}$-amônio, $\mathrm{N}$-nitrato e $\mathrm{N}$ inorgânico no solo, nas duas épocas de amostragem, foram maiores nas doses 120 e $180 \mathrm{~kg} \mathrm{ha}^{-1}$ em relação à dose 60 $\mathrm{kg} \mathrm{ha}^{-1}$, exceto em Votuporanga 1998/99. Nesse experimento, os efeitos ocorreram apenas para $\mathrm{N}$-nitrato e $\mathrm{N}$ inorgânico na primeira amostragem, de maneira semelhante aos resultados já apresentados para o contraste testemunha $\mathrm{x}$ adubado.

Conforme já mencionado, o efeito da adubação sobre os teores de $\mathrm{N}$ inorgânico no solo foi pouco pronunciado em Votuporanga 1998/99, independentemente da época de aplicação, mesmo nas parcelas que receberam $240 \mathrm{~kg} \mathrm{ha}^{-1}$ de N. Praticamente não houve efeito do modo de aplicação de $\mathrm{N}$ sobre o $\mathrm{N}$ inorgânico do solo. Já, em Cândido Mota, houve efeito do modo de aplicação do fertilizante nitrogenado sobre os teores de $\mathrm{N}$ inorgânico no solo. Na primeira amostragem os teores de nitrato aumentaram proporcionalmente com a dose aplicada na semeadura, e não com a dose da primeira cobertura. Por outro lado, na segunda amostragem os efeitos do modo de aplicação de N foram contraditórios entre as doses 60 e $240 \mathrm{~kg} \mathrm{ha}^{-1}$ : para a dose $60 \mathrm{~kg} \mathrm{ha}^{-1}$ os teores de nitrato e $\mathrm{N}$ inorgânico foram maiores quando a aplicação foi toda em cobertura, e para a dose $240 \mathrm{~kg} \mathrm{ha}^{-1}$ foram maiores quando aumentou a proporção no sulco de semeadura.

Em Palmital, os efeitos das doses dos fertilizantes nitrogenados no aumento dos teores de $\mathrm{N}$ no solo foram consistentes nos dois experimentos, com maior intensidade para a maior dose $\left(180 \mathrm{~kg} \mathrm{ha}^{-1}\right)$ no último ano (2000/01). Nos dois anos agrícolas, o excedente hídrico foi desprezível no período da emergência até a segunda amostragem do solo, reduzindo ou anulando as perdas por lixiviação e favorecendo a persistência do efeito dos tratamentos sobre o $\mathrm{N}$ inorgânico do solo.

Palmital 1999/00 foi o único experimento do subprojeto nitrogênio x genótipos no qual não houve diferença entre as doses 120 e $180 \mathrm{~kg} \mathrm{ha}^{-1}$ para os teores de $\mathrm{N}$ inorgânico no solo na primeira amostragem. Ressalte-se que a primeira amostragem foi realizada sempre após da aplicação a primeira e imediatamente antes da segunda 
cobertura, ou seja, após a aplicação da metade da dose do tratamento, correspondendo nesse caso a 60 e $90 \mathrm{~kg} \mathrm{ha}^{-1}$ de $\mathrm{N}$.

Em 2000/01 as duas amostragens foram realizadas com 15 dias de diferença uma da outra (a $1^{\mathrm{a}}$ aos 30/31 dias após a semeadura e a $2^{\mathrm{a}}$ aos 45/47 dias após a semeadura), sendo mais próximas do que a de todos os outros experimentos. Mesmo tendo sido aplicada a metade da dose da adubação nitrogenada de cobertura imediatamente após a primeira amostragem, verificou-se redução dos valores de $\mathrm{N}$ inorgânico no solo (amônio e nitrato) na segunda amostragem, exceto para a dose $180 \mathrm{~kg} \mathrm{ha}^{-1}$ de $\mathrm{N}$ que, provavelmente, foi excessiva. Esse período entre as duas amostragens correspondeu, coincidentemente, ao período de maior absorção de $\mathrm{N}$ pela planta. Corroborando com as observações anteriores, deve ter havido maior absorção de $\mathrm{N}$ na forma de nitrato, mesmo no tratamento testemunha.

Na média dos tratamentos, os teores de $\mathrm{N}$ inorgânico foram maiores na camada superficial, exceto em Votuporanga 1999/00 na segunda amostragem, em que a diferença entre as profundidades não foi significativa. Porém, ao desdobrar o efeito profundidade $\mathrm{x}$ tratamento, as diferenças em profundidade do $\mathrm{N}$ inorgânico ocorreram em todas as doses de $\mathrm{N}$ apenas em Votuporanga 1998/99. Provavelmente, por se tratar de áreas em plantio direto, a subdivisão da amostragem da camada superficial em 0-10 e 10-20 cm em Votuporanga 1998/99, diferenciou melhor a camada superficial, mais rica em matéria orgânica e, consequentemente, com maior atividade microbiana e ciclagem de nitrogênio.

Na dose zero houve diferença entre profundidades em Votuporanga 1998/99 para todas as doses e formas de $\mathrm{N}$ inorgânico, conforme já citado, e especificamente para $\mathrm{N}$ $\mathrm{NO}_{3}$ na primeira amostragem em Palmital 1999/00 e Palmital 2000/01. Na dose zero na primeira amostragem, o N-NO 3 foi maior nas camadas superficiais em Palmital 1999/00 e nas camadas subsuperficiais em Palmital 2000/01. Já, na dose $60 \mathrm{~kg} \mathrm{ha}^{-1}$ de $\mathrm{N}$ e especificamente no subprojeto Parcelamento em Cândido Mota, houve diferença de N$\mathrm{NO}_{3}$ e $\mathrm{N}$ inorgânico em profundidade apenas quando o $\mathrm{N}$ foi aplicado totalmente na base, e não em cobertura (primeira e segunda amostragens). No estudo Genótipos x Nitrogênio, por sua vez, verificou-se que na dose $60 \mathrm{~kg} \mathrm{ha}^{-1}$ houve diferença entre 
profundidades para as duas formas de $\mathrm{N}$ inorgânico em Palmital 1999/00 nas duas amostragens e apenas para $\mathrm{N}-\mathrm{NO}_{3}$ e $\mathrm{N}$ inorgânico em Votuporanga 1999/00 e Palmital 2000/01 na primeira amostragem. Em todos esses casos de diferença significativa entre profundidades, os teores foram maiores na camada superficial. Ressalte-se que houve deficiência hídrica acentuada em Palmital 1999/00, reduzindo ou anulando as perdas por lixiviação, e que somente neste experimento os teores de $\mathrm{N}^{-N_{3}}$ e $\mathrm{N}$ inorgânico diferiram entre as camadas 20-40 e 40-60 cm nas duas amostragens, sendo maior em 20$40 \mathrm{~cm}$.

Os resultados dos experimentos em conjunto mostram que predominou a forma $\mathrm{N}$-nitrato quando a adubação proporcionou aumento expressivo do $\mathrm{N}$ inorgânico, enquanto as formas $\mathrm{N}$-nitrato e $\mathrm{N}$-amônio foram equivalentes nos cultivos de milho com ausência ou pouca adubação nitrogenada. Por se tratar de plantio direto, sugere-se que nos próximos trabalhos a camada $0-20 \mathrm{~cm}$ seja amostrada de $10 \mathrm{em} 10 \mathrm{~cm}$ para diferenciar melhor o gradiente de $\mathrm{N}$ inorgânico no solo. 


\subsection{Subprojeto Genótipos x Nitrogênio}

As menores produtividades foram obtidas em Votuporanga e Palmital, em 1999/2000 (Tabela 18), devido à pior distribuição das chuvas durante o desenvolvimento da cultura. Apesar da condição de extrema acidez do solo em Itapeva, a produtividade média foi igual a $6,8 \mathrm{tha}^{-1}$.

Os maiores teores de N nos grãos foram obtidos em Itapeva 1998/99 e Votuporanga 2000/01 e os menores em Votuporanga 1998/99, tanto na média como em cada dose individualmente. Itapeva 1998/99 também apresentou, juntamente com Cândido Mota 1998/99, os maiores valores médios de exportação de nitrogênio, próximos de 100 $\mathrm{kg} \mathrm{ha}^{-1}$.

Houve respostas à adubação nitrogenada em todos os experimentos para os três parâmetros estudados. O conteúdo de $\mathrm{N}$ nos grãos aumentou até a maior dose de $\mathrm{N}$, exceto em Itapeva 1999/00 e Votuporanga 1999/2000, enquanto a produtividade decresceu a partir de um ponto de máximo (Tabela 19). Por conseqüência, os pontos de máxima resposta à aplicação de $\mathrm{N}$ foram quase sempre superiores para os resultados de exportação de $\mathrm{N}$ do que para os de produtividade de grãos. Isso sugere a existência de consumo de luxo pelas plantas e a exportação desnecessária de nitrogênio. Porém, o aumento contínuo do conteúdo de $\mathrm{N}$ nos grãos com a adubação é vantajoso quanto ao aspecto qualidade nutricional dos grãos.

O aumento relativo dos valores dos parâmetros estudados em função da adubação foi maior em 1999/00, ano agrícola que se obtive as menores produtividades (Tabela 20). Ao contrário do que geralmente é preconizado, o estresse hídrico ocorrido no segundo ano acentuou a resposta da cultura do milho à adubação. Observa-se também que não existiu relação consistente entre os teores de $\mathrm{N}$ inorgânico no solo por ocasião da semeadura, apresentados anteriormente, e a resposta da cultura à adubação nitrogenada.

Houve interação significativa entre genótipos e doses de nitrogênio somente nos experimentos de 1998/1999 (Tabelas 21 a 30). A interação foi significativa para produtividade de grãos em Votuporanga 1998/1999, Cândido Mota 1998/1999 e Itapeva 1998/1999, enquanto para exportação de N, foi significativa em Cândido Mota 
Tabela 18. Valores médios de produtividade, $\mathrm{N}$ nos grãos, exportação de $\mathrm{N}$ em função das doses de nitrogênio em cobertura e significância do teste $F$ nos experimentos do subprojeto "Resposta de Genótipos de Milho ao Nitrogênio", realizado de 1998/99 a 2000/01 em diferentes locais do Estado de São Paulo.

\begin{tabular}{|c|c|c|c|c|c|c|c|c|c|}
\hline \multirow[t]{2}{*}{ Local } & \multirow[t]{2}{*}{ Ano } & \multicolumn{5}{|c|}{ Dose de nitrogênio em cobertura } & \multicolumn{3}{|c|}{ Teste $\mathrm{F}^{(1)}$} \\
\hline & & 0 & 60 & 120 & 180 & Média & $\mathrm{N}$ & $\mathrm{C}$ & $\mathrm{CxN}$ \\
\hline \multicolumn{10}{|c|}{ Produtividade, $\mathrm{kg} \mathrm{ha}^{-1}$} \\
\hline Votuporanga & 98/99 & 4.611 & 5.644 & 5.916 & 5.952 & 5.531 & $* *$ & $* *$ & $*$ \\
\hline Cândido Mota & 98/99 & 6.970 & 7.453 & 7.710 & 7.754 & 7.472 & $* *$ & $* *$ & $*$ \\
\hline Itapeva & 98/99 & 6.121 & 6.807 & 7.058 & 7.071 & $6.7 \dot{6} 4$ & $* *$ & $* *$ & $* *$ \\
\hline Votuporanga & $99 / 00$ & 2.509 & 4.391 & 5.640 & 5.748 & 4.572 & $* *$ & $* *$ & Ns \\
\hline Palmital & $99 / 00$ & 2.475 & 4.078 & 4.338 & 5.229 & 4.030 & $* *$ & $* *$ & Ns \\
\hline Votuporanga & $00 / 01$ & 5.512 & 6.270 & 6.571 & 6.728 & 6.270 & $* *$ & $* *$ & Ns \\
\hline Palmital & $00 / 01$ & 6.254 & 7.181 & 7.512 & 7.738 & 7.171 & $* *$ & $* *$ & Ns \\
\hline \multicolumn{10}{|c|}{$\mathrm{N}$ nos grãos, $\mathrm{g} \mathrm{kg}^{-1}$} \\
\hline Votuporanga & $98 / 99$ & 11,6 & 11,9 & 12,6 & 12,9 & 12,2 & $* *$ & $* *$ & Ns \\
\hline Cândido Mota & $98 / 99$ & 13,0 & 13,4 & 13,8 & 14,1 & 13,6 & $* *$ & $* *$ & Ns \\
\hline Itapeva & $98 / 99$ & 13,7 & 14,8 & 15,1 & 15,3 & 14,7 & $* *$ & $* *$ & Ns \\
\hline Votuporanga & $99 / 00$ & 12,9 & 12,7 & 14,3 & 15,1 & 13,7 & $* *$ & $* *$ & Ns \\
\hline Palmital & $99 / 00$ & 11,4 & 12,2 & 14,1 & 14,9 & 13,2 & $* *$ & $* *$ & Ns \\
\hline Votuporanga & $00 / 01$ & 13,5 & 13,8 & 14,2 & 14,4 & 14,0 & $* *$ & $* *$ & Ns \\
\hline Palmital & $00 / 01$ & 11,8 & 12,8 & 13,9 & 14,4 & 13,2 & $* *$ & $* *$ & Ns \\
\hline \multicolumn{10}{|c|}{ Exportação de $\mathrm{N}, \mathrm{kg} \mathrm{ha}^{-1}$} \\
\hline Votuporanga & $98 / 99$ & 53,0 & 67,2 & 74,6 & 76,4 & 67,8 & $* *$ & $* *$ & Ns \\
\hline Cândido Mota & $98 / 99$ & 90,4 & 99,9 & 107,6 & 108,9 & 101,7 & $* *$ & $* *$ & $*$ \\
\hline Itapeva & $98 / 99$ & 86,6 & 100,2 & 106,3 & 107,8 & 99,5 & $* *$ & $* *$ & $*$ \\
\hline Votuporanga & $99 / 00$ & 31,9 & 55,3 & 78,2 & 84,0 & 62,3 & $* *$ & $* *$ & Ns \\
\hline Palmital & $99 / 00$ & 27,8 & 49,4 & 60,5 & 76,9 & 53,7 & $* *$ & $* *$ & Ns \\
\hline Votuporanga & $00 / 01$ & 74,2 & 85,7 & 92,7 & 96,8 & 87,4 & $* *$ & $* *$ & Ns \\
\hline Palmital & $00 / 01$ & 73,3 & 92,0 & 104,0 & 110,8 & 95,0 & $* *$ & $* *$ & Ns \\
\hline
\end{tabular}

T) Teste $\mathrm{F}:{ }^{*} \mathrm{e}^{* *}=$ significativo a $5 \%$ e $1 \%$ respectivamente, e ns = não significativo 
Tabela 19. Equações de regressão da produtividade de grãos, conteúdo de $\mathrm{N}$ e exportação de $\mathrm{N}$ nos grãos, em função das doses de nitrogênio em cobertura $(0 \mathrm{a}$ $180 \mathrm{~kg} \mathrm{ha}^{-1}$ ), no subprojeto "Resposta de Genótipos de Milho ao Nitrogênio".

\begin{tabular}{|c|c|c|c|}
\hline Local & Ano & Equação & $\mathrm{r}^{2}$ \\
\hline & \multicolumn{3}{|c|}{ Produtividade de grãos, $\mathrm{kg} \mathrm{ha}^{-1}$} \\
\hline Votuporanga & $98 / 99$ & $Y=4637,32+19,62 x-0,07 x^{2}$ & 0,99 \\
\hline Cândido Mota & $98 / 99$ & $Y=6962,22+10,77 x-0,04 x^{2}$ & 1,00 \\
\hline Itapeva & 98/99 & $Y=6130,90+13,58 x-0,05 x^{2}$ & 1,00 \\
\hline Votuporanga & $99 / 00$ & $Y=2483,89+40,44 x-0,12 x^{2}$ & 1,00 \\
\hline Palmital & $99 / 00$ & $Y=2573,20+23,11 x-0,05 x^{2}$ & 0,95 \\
\hline Votuporanga & $00 / 01$ & $Y=5528,18+14,09 x-0,04 x^{2}$ & 0,99 \\
\hline \multirow[t]{2}{*}{ Palmital } & $00 / 01$ & $Y=6278,25+16,74 x-0,05 x^{2}$ & 0,99 \\
\hline & \multicolumn{3}{|c|}{$\mathrm{N}$ nos grãos, $\mathrm{g} \mathrm{kg}^{-1}$} \\
\hline Votuporanga & $98 / 99$ & $Y=11,55+0,008 x$ & 0,97 \\
\hline Cândido Mota & 98/99 & $y=13,00+0,006 x$ & 0,99 \\
\hline Itapeva & $98 / 99$ & $y=13,74+0,02 x-0,00005 x^{2}$ & 0,45 \\
\hline Votuporanga & $99 / 00$ & $y=12,81+0,0007 x-0,00007 x^{2}$ & 0,92 \\
\hline Palmital & $99 / 00$ & $y=11,31+0,020 x$ & 0,97 \\
\hline Votuporanga & $00 / 01$ & $Y=11,88+0,015 x$ & 1,00 \\
\hline \multirow[t]{2}{*}{ Palmital } & $00 / 01$ & $Y=13,50+0,005 x$ & 0,99 \\
\hline & \multicolumn{3}{|c|}{ Exportação de N nos grãos, $\mathrm{kg} \mathrm{ha}^{-1}$} \\
\hline Votuporanga & $98 / 99$ & $Y=53,06+0,28 x-0,0009 x^{2}$ & 1,00 \\
\hline Cândido Mota & $98 / 99$ & $y=90,17+0,21 x-0,0006 x^{2}$ & 1,00 \\
\hline Itapeva & 98/99 & $y=86,74+0,27 x-0,0008 x^{2}$ & 1,00 \\
\hline Votuporanga & $99 / 00$ & $y=31,09+0,52 x-0,0012 x^{2}$ & 0,99 \\
\hline Palmital & $99 / 00$ & $y=29,88+0,26 x$ & 0,99 \\
\hline Votuporanga & $00 / 01$ & $Y=73,39+0,356 x-0,0008 x^{2}$ & 1,00 \\
\hline Palmital & $00 / 01$ & $Y=74,27+0,22 x-0,0005 x^{2}$ & 1,00 \\
\hline
\end{tabular}


Tabela 20. Produtividade máxima de grãos de milho, doses de nitrogênio em cobertura correspondentes à produtividade máxima e aumento relativo da produtividade, em experimentos desenvolvidos em diferentes locais do Estado de São Paulo nos anos agrícolas 1998/99 a 2000/01.

\begin{tabular}{lcccc}
\hline & & \multicolumn{2}{c}{ Produtividade máxima } & $\begin{array}{c}\text { Aumento relativo } \\
\text { Local }\end{array}$ \\
\cline { 3 - 5 } de produtividade
\end{tabular}

1998/1999 e Itapeva 1998/1999. Não houve interação genótipo x nitrogênio para o conteúdo de nitrogênio nos grãos.

Estimou-se o aumento relativo da produtividade e exportação de nitrogênio, a partir do ponto de mínima e máxima das equações de resposta à adubação nitrogenada, quando o efeito do nitrogênio foi significativo estatisticamente (Tabela 31). A cultivar XL 212 apresentou comportamento diferenciado dos demais, não aumentando a produtividade de grãos com a aplicação de nitrogênio em cobertura em dois locais. As cultivares IAC VI, XL 251 e Master aumentaram significativamente a produtividade nos 3 locais, e as cultivares BR 3123, Dina 766, C 333B e BR 4157, apenas em Itapeva e Votuporanga. Já a P32R21, aumentou a produtividade com a adubação nos dois experimentos em que foi avaliada.

Como conseqüência da interação entre locais para a resposta da produtividade dos cultivares à adubação, os cultivares também não apresentaram o mesmo padrão de resposta para o parâmetro exportação de nitrogênio. Embora a magnitude da resposta da exportação de N pelas cultivares tenha variado entre o locais, verifica-se que o XL 212 
Tabela 21. Resposta de cultivares de milho ao nitrogênio em Votuporanga (SP) em 1998/99, avaliada pela produção de grãos

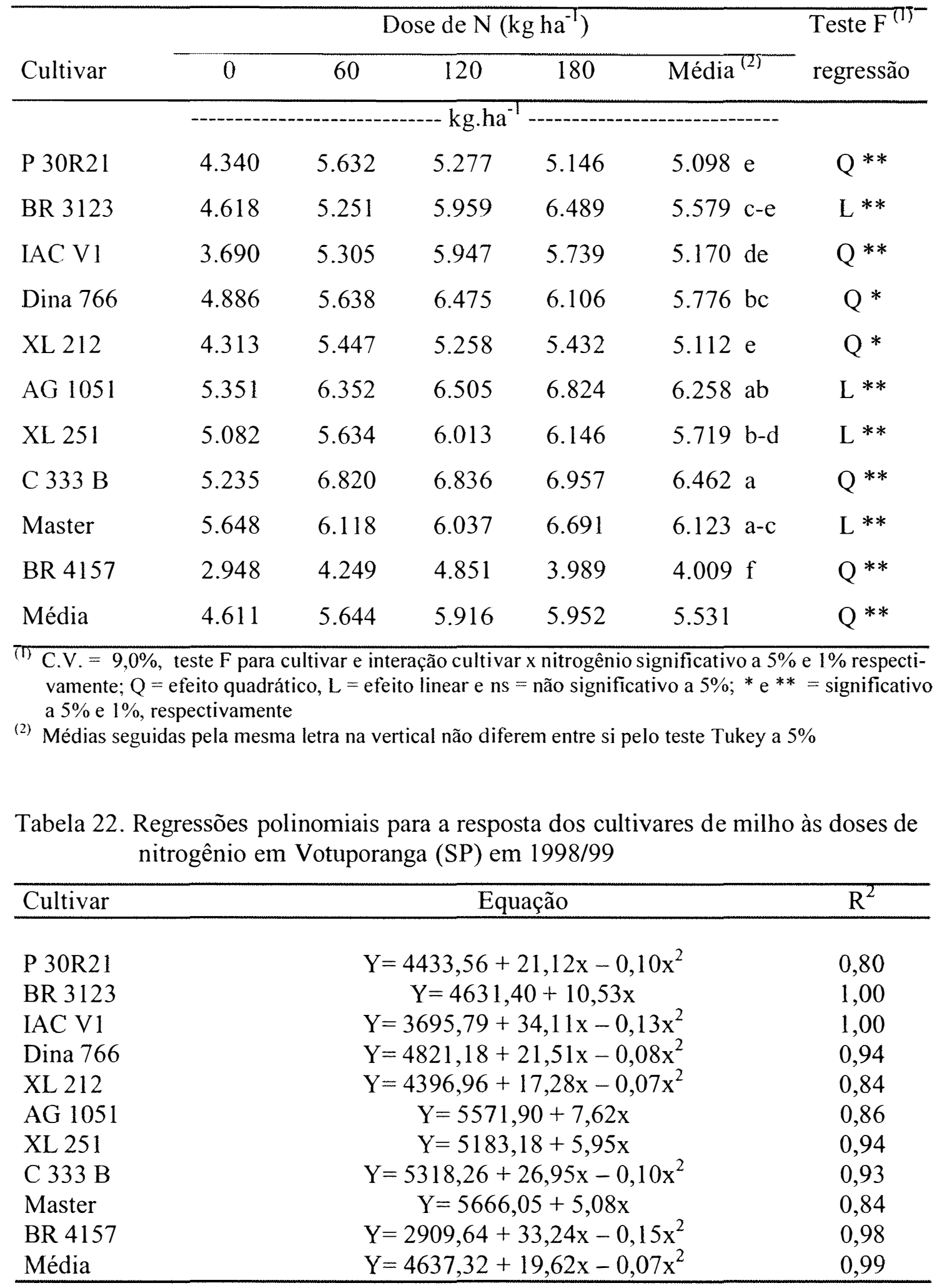


Tabela 23. Resposta de cultivares de milho ao nitrogênio em Cândido Mota (SP) em 1998/99, avaliada pela produção de grãos

\begin{tabular}{|c|c|c|c|c|c|c|}
\hline \multirow[b]{2}{*}{ Cultivar } & \multicolumn{5}{|c|}{ Dose de $\mathrm{N}\left(\mathrm{kg} \mathrm{ha}^{-1}\right)$} & \multirow{2}{*}{$\begin{array}{l}\text { Teste } \mathrm{F}^{(1)} \\
\text { regressão }\end{array}$} \\
\hline & 0 & 60 & 120 & 180 & Média $^{(2)}$ & \\
\hline \multicolumn{7}{|c|}{ 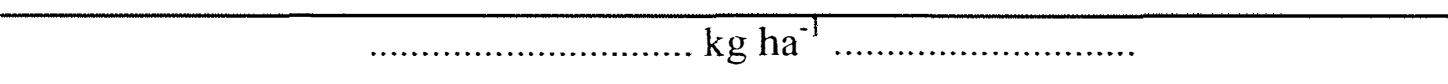 } \\
\hline P 30R21 & 5.449 & 6.378 & 7.533 & 6.712 & $6.518 \mathrm{~d}$ & $\mathrm{Q}^{* *}$ \\
\hline BR 3123 & 6.496 & 6.589 & 7.673 & 7.031 & $6.947 \mathrm{~cd}$ & Ns \\
\hline IAC VI & 5.692 & 5.943 & 6.863 & 6.807 & $6.326 \mathrm{~d}$ & $\mathrm{~L} * *$ \\
\hline Dina 766 & 7.958 & 8.288 & 8.584 & 8.720 & $8.387 \mathrm{a}$ & Ns \\
\hline XL 212 & 6.828 & 7.107 & 5.798 & 6.764 & $6.624 \mathrm{~d}$ & Ns \\
\hline AG 1051 & 7.101 & 7.594 & 7.456 & 7.738 & $7.472 \mathrm{bc}$ & Ns \\
\hline XL 251 & 7.471 & 8.263 & 8.551 & 8.133 & $8.105 \mathrm{ab}$ & $\mathrm{Q}^{*}$ \\
\hline C $333 \mathrm{~B}$ & 7.856 & 7.803 & 8.605 & 8.186 & $8.113 \mathrm{ab}$ & Ns \\
\hline Master & 6.748 & 8.566 & 8.121 & 8.399 & $7.959 \mathrm{ab}$ & $\mathrm{Q}^{*}$ \\
\hline Exceler & 8.104 & 7.994 & 8.350 & 8.612 & $8.265 \mathrm{a}$ & Ns \\
\hline Média & 6.970 & 7.453 & 7.710 & 7.754 & 7.472 & $\mathrm{Q}^{* *}$ \\
\hline \multicolumn{7}{|c|}{$\begin{array}{l}\text { (T.V. }=7,4 \% \text {, teste } F \text { para cultivar e interação cultivar x nitrogênio significativo a } 5 \% \text { e } \\
\text { vamente; } Q=\text { efeito quadrático, } L=\text { efeito linear e ns = não significativo a } 5 \% ; \mathrm{e}^{* *}= \\
\text { a } 5 \% \text { e } 1 \% \text {, respectivamente } \\
\text { (2) Médias seguidas pela mesma letra na vertical não diferem entre si pelo teste Tukey a } 5 \%\end{array}$} \\
\hline \multicolumn{7}{|c|}{$\begin{array}{l}\text { Tabela 24. Regressões polinomiais para a resposta dos cultivares às doses de nitrogêni } \\
\text { em Cândido Mota em 1998/99 }\end{array}$} \\
\hline Cultivar & & & $\mathrm{Eq}$ & & & $\mathrm{R}^{2}$ \\
\hline P 30R21 & & & $39,12+$ &, $11 x-$ & & 0,89 \\
\hline BR 3123 & & & $60,50+$ &, $66 x-$ & & 0,57 \\
\hline IAC V1 & & & $=5886$ & $+7,12$ & & 0,85 \\
\hline Dina 766 & & & 51,75 & $72 x-c$ & & 1,00 \\
\hline XL 212 & & & $20,83-$ & $08 x+c$ & & 0,24 \\
\hline AG 1051 & & & 53,28 & $60 x-c$ & & 0,75 \\
\hline XL 251 & & $Y=$ & $60,88+$ & $93 x-$ & & 1,00 \\
\hline C $333 \mathrm{~B}$ & & & 52,47 & $56 x-c$ & & 0,47 \\
\hline Master & & $Y=$ & $97,32+$ &, $76 x-$ & & 0,78 \\
\hline Exceler & & & 75,92 & $52 x+c$ & & 0,93 \\
\hline Média & & $Y=$ & $62,22+$ &, $77 x-$ & & 1,00 \\
\hline
\end{tabular}


Tabela 25. Nitrogênio exportado pelos grãos em cultivares de milho plantados em Cândido Mota (SP) em 1998/99, em função de doses de nitrogênio

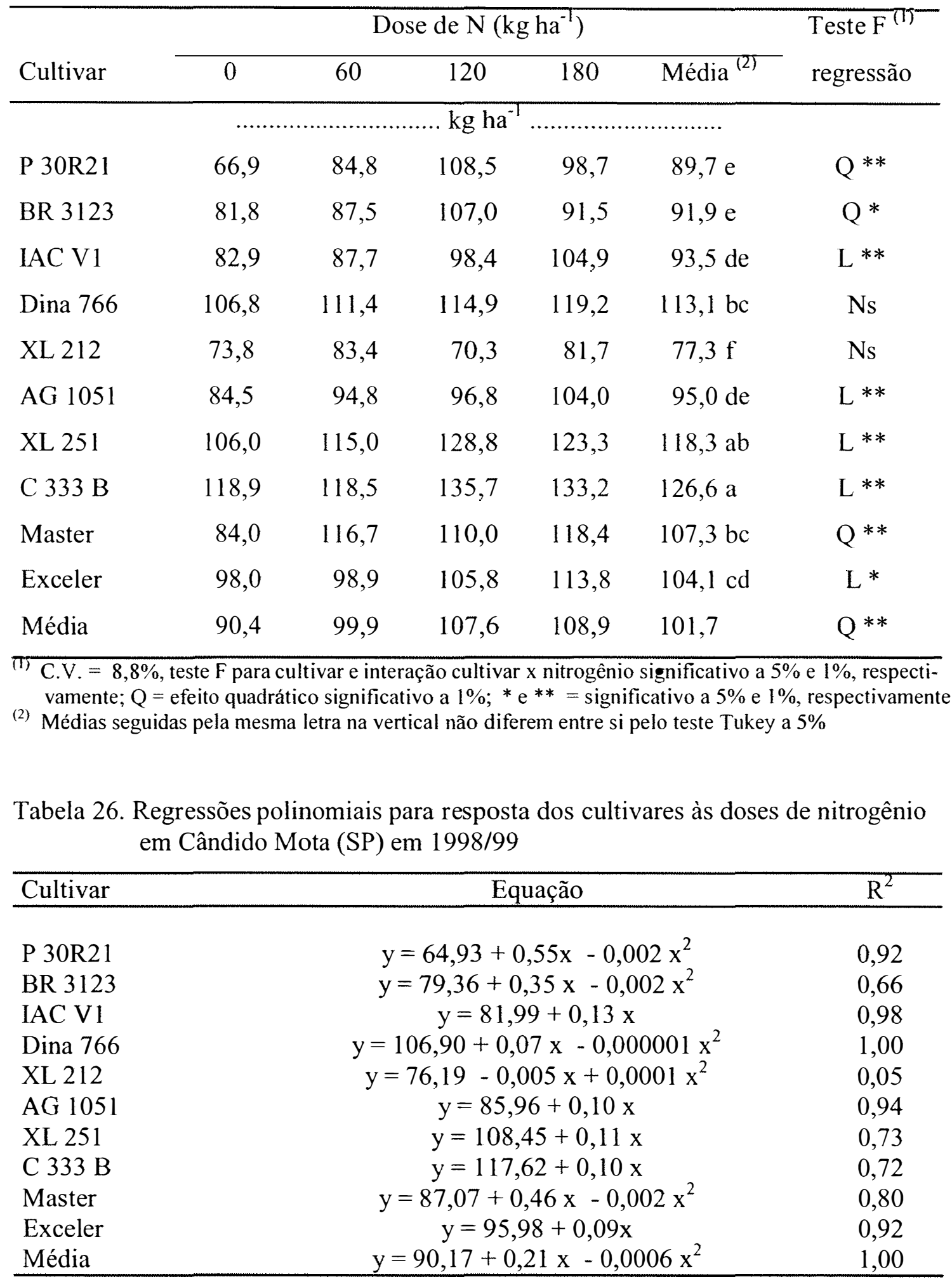


Tabela 27. Resposta de cultivares de milho ao nitrogênio em Itapeva em 1998/99, avaliada pela produção de grãos

\begin{tabular}{|c|c|c|c|c|c|c|}
\hline \multirow[b]{2}{*}{ Cultivar } & \multicolumn{5}{|c|}{ Dose de $\mathrm{N}\left(\mathrm{kg} \mathrm{ha}^{-1}\right)$} & \multirow{2}{*}{$\begin{array}{l}\text { Teste } \mathrm{F}^{\left(\mathrm{T}^{-}\right.} \\
\text {regressão }\end{array}$} \\
\hline & 0 & 60 & 120 & 180 & Média $^{(2)}$ & \\
\hline \multicolumn{7}{|c|}{$\mathrm{kg} \mathrm{ha}^{-1}$} \\
\hline P 30R21 & - & - & - & - & - & - \\
\hline BR 3123 & 5.070 & 5.364 & 6.072 & 5.953 & 5.615 ef & $\mathrm{L} * *$ \\
\hline IAC V1 & 4.625 & 5.217 & 5.651 & 5.484 & $5.244 \mathrm{f}$ & $\mathrm{L} * *$ \\
\hline Dina 766 & $5.899^{\circ}$ & 6.207 & 7.066 & 6.969 & $6.535 \mathrm{~d}$ & $L^{* *}$ \\
\hline XL 212 & 5.571 & 6.151 & 5.463 & 6.000 & $5.796 \mathrm{e}$ & Ns \\
\hline AG 1051 & 6.508 & 8.004 & 8.116 & 8.504 & $7.783 \mathrm{~b}$ & $\mathrm{Q}^{*}$ \\
\hline XL 251 & 6.423 & 7.531 & 7.228 & 7.403 & $7.146 \mathrm{c}$ & $\mathrm{L} * *$ \\
\hline C $333 \mathrm{~B}$ & 8.071 & 8.496 & 9.460 & 9.199 & $8.806 \mathrm{a}$ & $\mathrm{L} * *$ \\
\hline Master & 6.736 & 7.025 & 7.816 & 6.912 & $7.122 \mathrm{c}$ & $\mathrm{Q}^{*}$ \\
\hline BR 4157 & 6.184 & 7.268 & 6.648 & 7.217 & $6.829 \mathrm{~cd}$ & $\mathrm{~L} *$ \\
\hline Média & 6.121 & 6.807 & 7.058 & 7.071 & 6.764 & $\mathrm{Q}^{* *}$ \\
\hline \multicolumn{7}{|c|}{$\begin{array}{l}\text { (T) } \mathrm{V}=7,2 \% \text {, teste } \mathrm{F} \text { para cultivar e interação cultivar } \times \text { nitrogênio significativo a } 1 \% \text {; } \mathrm{Q}=\text { efeito qua } \\
\text { drático, } \mathrm{L}=\text { efeito linear e ns = não significativo a } 5 \% ;{ }^{*} \mathrm{e}^{* *}=\text { significativo a } 5 \% \text { e } 1 \% \text { respectiva- } \\
\text { mente } \\
{ }^{(2)} \text { Médias seguidas pela mesma letra na vertical não diferem entre si entre si pelo teste Tukey a } 5 \%\end{array}$} \\
\hline \multicolumn{7}{|c|}{$\begin{array}{l}\text { Tabela 28. Regressões polinomiais para a resposta dos cultivares às doses de nitrogênio } \\
\text { em Itapeva (SP) em 1998/99 }\end{array}$} \\
\hline Cultivar & & & Equ & & & $\mathrm{R}^{2}$ \\
\hline P 30R 21 & & & & & & - \\
\hline BR 3123 & & & $=5111$, & $+5,60 x$ & & 0,82 \\
\hline IAC V1 & & & $=4792$, & $+5,02 x$ & & 0,75 \\
\hline Dina 766 & & & $=5924$, & $+6,78 x$ & & 0,84 \\
\hline XL 212 & & $Y=$ & $5,70+$ & $4 x-0$, & & 0,06 \\
\hline AG 1051 & & $Y=$ & $1,00+$ & $02 x-0$ & & 0,94 \\
\hline XL 251 & & & $=6750$, & $+4,40 x$ & & 0,47 \\
\hline C $333 \mathrm{~B}$ & & & $=8154$, & $+7,25 x$ & & 0,78 \\
\hline Master & & $Y=$ & $6,20+$ & $11 x-0$ & & 0,65 \\
\hline BR 4157 & & & $=6457$, & $+4,13 x$ & & 0,39 \\
\hline Média & & $Y=$ & $0,90+$ & $58 x-0$ & & 1,00 \\
\hline
\end{tabular}


Tabela 29. Nitrogênio exportado pelos grãos em cultivares de milho plantados em Itapeva (SP) em 1998/99, em função de doses de nitrogênio

\begin{tabular}{|c|c|c|c|c|c|c|}
\hline \multirow[b]{2}{*}{ Cultivar } & \multicolumn{5}{|c|}{ Dose de $N\left(\mathrm{~kg} \mathrm{ha}^{-1}\right)$} & \multirow{2}{*}{$\begin{array}{l}\text { Teste }^{(1)} \\
\text { regressão }\end{array}$} \\
\hline & 0 & 60 & 120 & 180 & Média ${ }^{(2)}$ & \\
\hline & & & kg ha & & ..... & \\
\hline P 30R21 & - & - & - & - & - & - \\
\hline BR 3123 & 73,3 & 79,3 & 91,9 & 93,3 & $84,4 \mathrm{c}$ & $\mathrm{L} * *$ \\
\hline IAC V1 & 67,7 & 85,9 & 88,5 & 90,2 & $83,1 \mathrm{c}$ & $\mathrm{L}^{* *}$ \\
\hline Dina 766 & 83,3 & 98,1 & 111,5 & 102,9 & $98,9 \mathrm{~b}$ & $\mathrm{Q}^{*}$ \\
\hline XL 212 & 70,1 & 86,7 & 80,4 & 89,2 & $81,6 \mathrm{c}$ & $\mathrm{L}^{*}$ \\
\hline AG 1051 & 86,6 & 106,2 & 117,1 & 127,3 & $109,3 \mathrm{~b}$ & $\mathrm{~L} * *$ \\
\hline XL 251 & 81,5 & 105,6 & 108,9 & 115,8 & $102,9 \mathrm{~b}$ & $\mathrm{~L} * *$ \\
\hline C $333 \mathrm{~B}$ & 104,4 & 132,0 & 142,9 & 142,9 & $130,5 \mathrm{a}$ & $\mathrm{Q}^{* *}$ \\
\hline Master & 95,3 & 100,6 & 116,1 & 97,3 & $102,3 \mathrm{~b}$ & $\mathrm{Q} * *$ \\
\hline BR 4157 & 90,1 & 107,1 & 100,0 & 111,0 & $102,0 \mathrm{~b}$ & $\mathrm{~L} * *$ \\
\hline Média & 86,6 & 100,2 & 106,3 & 107,8 & 99,5 & $\mathrm{Q}^{*}$ \\
\hline \multirow{2}{*}{\multicolumn{7}{|c|}{$\begin{array}{l}\text { (1).V. }=9,5 \% \text {, teste } \mathrm{F} \text { para cultivar e interação cultivar x nitrogênio significativo a } 1 \% \text { e } 5 \% \text {, respecti } \\
\text { vamente; } \mathrm{Q}=\text { efeito quadrático, } \mathrm{L}=\text { efeito linear significativo a } 5 \% ;{ }^{*} \mathrm{e}^{* *}=\text { significativo a } 5 \% \text { e } 1^{\circ} \\
\text { respectivamente } \\
\text { (2) } \\
\text { Médias seguidas pela mesma letra na vertical não diferem entre si pelo teste Tukey a } 5 \% \\
\text { Tabela } 30 . \text { Regressões polinomiais para resposta dos cultivares às doses de nitrogênio } \\
\quad \text { em Itapeva (SP) em } 1998 / 99\end{array}$}} \\
\hline & & & & & & \\
\hline Cultivar & & \multicolumn{4}{|c|}{ Equação } & $\mathrm{R}^{2}$ \\
\hline P 30R21 & & \multicolumn{4}{|c|}{-} & - \\
\hline BR 3123 & & \multicolumn{4}{|c|}{$y=75,56+0,12 x$} & 0,93 \\
\hline IAC V1 & & \multicolumn{4}{|c|}{$y=72,56+0,12 x$} & 0,76 \\
\hline Dina 766 & & \multicolumn{4}{|c|}{$y=82,27+0,41 x-0,002 x^{2}$} & 0,96 \\
\hline XL 212 & & \multicolumn{4}{|c|}{$y=73,95+0,09 x$} & 0,60 \\
\hline AG 1051 & & \multicolumn{4}{|c|}{$y=89,35+0,22 x$} & 0,97 \\
\hline XL 251 & & \multicolumn{4}{|c|}{$y=87,02+0,18 x$} & 0,84 \\
\hline C $333 \mathrm{~B}$ & & \multicolumn{4}{|c|}{$y=104,69+0,56 x-0,002 x^{2}$} & 1,00 \\
\hline Master & & \multicolumn{4}{|c|}{$y=93,08+0,34 x-0,002 x^{2}$} & 0,63 \\
\hline BR 4157 & & \multicolumn{4}{|c|}{$y=93,71+0,09 x$} & 0,61 \\
\hline Média & & \multicolumn{4}{|c|}{$y=86,74+0,27 x-0,0008 x^{2}$} & 1,00 \\
\hline
\end{tabular}


Tabela 31. Aumento máximo relativo da produtividade de grãos de milho de cultivares semeados em Cândido Mota, Votuporanga e Itapeva, devido à adubação nitrogenada de cobertura, e exportação de nitrogênio, considerando a interação cultivar $\mathrm{x}$ nitrogênio

\begin{tabular}{|c|c|c|c|c|c|}
\hline \multirow[b]{2}{*}{ Cultivar } & \multicolumn{3}{|c|}{ Produtividade } & \multicolumn{2}{|c|}{ Exportação } \\
\hline & Cândido Mota & Itapeva & Votuporanga & Cândido Mota & Itapeva \\
\hline P 30R21 & 35 & $-^{(1)}$ & 25 & 58 & $-^{(1)}$ \\
\hline BR 3123 & Ns & 20 & 41 & 19 & 29 \\
\hline IAC VI & 22 & 19 & 61 & 29 & 30 \\
\hline Dina 766 & $\mathrm{~ns}^{(2)}$ & 21 & 30 & Ns & 26 \\
\hline XL 212 & Ns & Ns & 24 & Ns & 22 \\
\hline AG 1051 & Ns & 27 & 25 & 21 & 44 \\
\hline XL 251 & 15 & 12 & 21 & 18 & 37 \\
\hline C 333 B & Ns & 16 & 34 & 15 & 37 \\
\hline Master & 24 & 14 & 16 & 30 & 16 \\
\hline BR 4157 & Ns & 12 & 63 & 17 & 17 \\
\hline Média & 10 & 15 & 30 & 21 & 26 \\
\hline
\end{tabular}

${ }^{\pi}$ Não avaliado; ${ }^{(2)}$ Modelo linear e quadrático não significativo

apresentou o menor aumento relativo na média dos dois locais. Comparando-se as variedades IAC V1 e BR 4157, verifica-se que elas apresentaram elevados e baixos aumentos relativos da exportação de nitrogênio, respectivamente.

Poder-se-ia sugerir que as cultivares menos produtivos devam apresentar maior teor de N nos grãos, e vice-versa. Os resultados obtidos com os híbridos C 333B e XL 212 sugerem que essa associação não é verdadeira. O C 333B apresentou adaptação satisfatória quanto à produtividade de grãos em todos os locais, bem como teor de $\mathrm{N}$ nos grãos superior à média dos experimentos; logo, destacou-se quanto à exportação de $\mathrm{N}$ nos grãos (Tabelas 32 e 33). $\mathrm{O}$ índice de correlação entre o teor de $\mathrm{N}$ e a produtividade de grãos de todas parcelas dos experimentos genótipos x nitrogênio, indica que a associação entre estes dois parâmetros é muito baixa, embora significativa (Figura 16). Evi- 


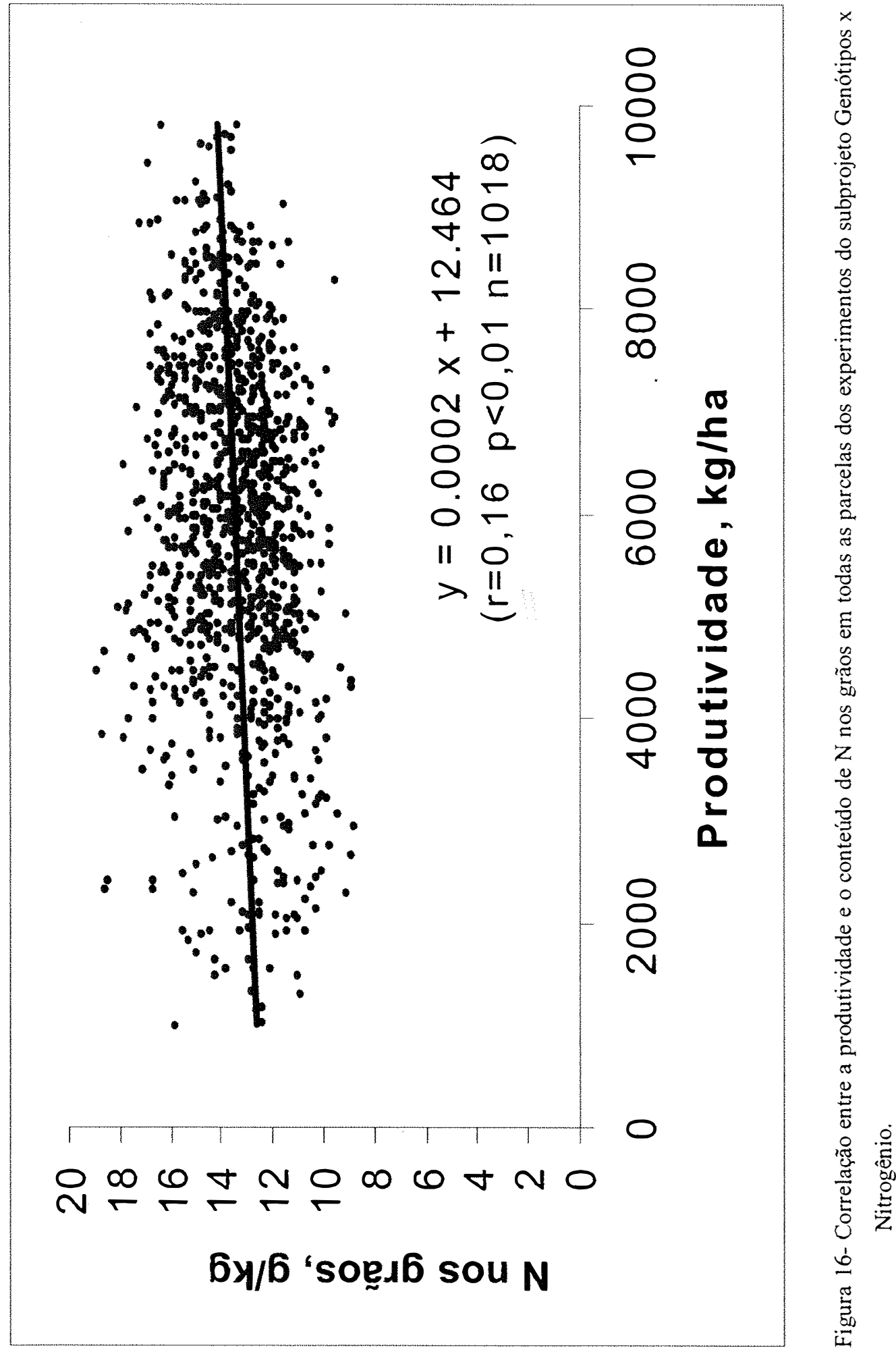


denciou-se essa correlação positiva porque obteve-se, para um mesmo híbrido, maiores produtividades nas maiores doses de nitrogênio que, por sua vez, elevaram os teores de $\mathrm{N}$ nos grãos. Os presentes resultados são diferentes aos de Dudley et al.(1977) e Tsai et al. (1992) que reportaram, para um conjunto de híbridos, correlação negativa entre a produtividade e o teor de $\mathrm{N}$ nos grãos.

A diferenciação das cultivares quanto ao nível de resposta é bastante complexa devido, entre outros fatores, à adaptação do germoplasma às condições edafoclimáticas regionais, que influi na expressão do potencial produtivo. A interação local x cultivar para os três parâmetros avaliados nas duas análises conjuntas (Tabelas 32 e 33), indica que as cultivares alteraram seu desempenho relativo em função dos ambientes.

O XL 212 esteve sempre entre as cultivares com menor teor de $\mathrm{N}$ nos grãos e, devido à predominância de germoplasma temperado, apresentou-se pouco adaptado às condições climáticas do Estado de São Paulo. Consequentemente, a exportação de nitrogênio por essa cultivar foi relativamente baixa.

A variedade BR 4157 foi semelhante à IAC V1 quanto aos altos teores de $\mathrm{N}$ nos grãos, mas diferiram quanto à adaptação produtiva: a IAC VI destacou-se nas áreas mais quentes e a BR 4157 nas regiões de clima mais ameno (Tabelas 21 a 30). Assim, a BR 4157 foi a que exportou menos nitrogênio porque a maioria dos locais era de baixa altitude.

A exportação de $\mathrm{N}$ não esteve relacionada, necessariamente, com a produtividade de grãos. As cultivares IAC Vl e 8410, apesar de terem sido umas das menos produtivas nos experimentos, apresentaram valores relativamente elevados dos teores de $\mathrm{N}$ grãos, favorecendo a exportação de nitrogênio (Tabelas 32 e 33). A AG 1051, por sua vez, apesar da excelente adaptação produtiva, apresentou teores relativamente baixos de $\mathrm{N}$ nos grãos em todos os locais, por isso não se destacou quanto à exportação de nitrogênio. Houve interação significativa entre genótipos e doses de nitrogênio para a produtividade de grãos, tanto na análise conjunta em 1998/99 como na análise em 1999/00 e 2000/01. Já a interação genótipo $\mathrm{x}$ nitrogênio para a exportação de $\mathrm{N}$ nos grãos, foi significativa apenas na análise conjunta 1998/99. 
Tabela 32. Análise conjunta da produtividade, teor e exportação de $\mathrm{N}$ nos grãos, em função de doses de nitrogênio e cultivar, em Votuporanga, Cândido Mota e Itapeva em 1998/99.

\begin{tabular}{|c|c|c|c|}
\hline Fatores da variação & Produtividade & $\mathrm{N}$ nos grãos & Exportação de $\mathrm{N}$ \\
\hline & $\mathrm{kg} \mathrm{ha}^{-1}$ & $\mathrm{~g} \mathrm{~kg}^{-1}$ & $\mathrm{~kg} \mathrm{ha}^{-1}$ \\
\hline \multicolumn{4}{|l|}{ Nitrogênio, $\mathrm{kg} \mathrm{ha}^{-1}$} \\
\hline 0 & 6192 & 13,3 & 82,2 \\
\hline 60 & 6833 & 14,0 & 94,8 \\
\hline 120 & 7133 & 14,3 & 101,6 \\
\hline 180 & 7180 & 14,5 & 103,7 \\
\hline \multicolumn{4}{|l|}{ Cultivar $^{(1)}$} \\
\hline C $333 \mathrm{~B}$ & $7663 \mathrm{a}$ & $15,2 \mathrm{a}$ & $116,4 \mathrm{a}$ \\
\hline AG 1051 & $7387 \mathrm{ab}$ & $13,0 \mathrm{e}$ & $96,8 \mathrm{c}$ \\
\hline XL 251 & $7353 \mathrm{a}-\mathrm{c}$ & $14,1 \mathrm{c}-\mathrm{e}$ & $104,2 \mathrm{~b}$ \\
\hline Dina 766 & 7279 bc & $14,2 b-d$ & $103,3 \mathrm{~b}$ \\
\hline Master & $7026 c$ & $13,6 \mathrm{e}$ & $96,2 \mathrm{c}$ \\
\hline BR 3123 & $6021 \mathrm{~d}$ & $13,7 \mathrm{de}$ & $82,6 \mathrm{de}$ \\
\hline IAC VI & $5984 \mathrm{~d}$ & $14,7 \mathrm{ab}$ & $87,8 \mathrm{~d}$ \\
\hline XL 212 & $5964 \mathrm{~d}$ & $13,1 \mathrm{e}$ & $77,5 \mathrm{e}$ \\
\hline P32R21 & - & 14,3 bc & - \\
\hline \multirow[t]{2}{*}{ Média } & 6834 & 14,0 & 95,6 \\
\hline & \multicolumn{3}{|c|}{$\mathrm{P}>\mathrm{F}^{(2)}$} \\
\hline Local & $* *$ & $* *$ & $* *$ \\
\hline Nitrogênio & $* *$ & $* *$ & ** \\
\hline Linear & $* *$ & ** & $* *$ \\
\hline Quadrática & $* *$ & * & $* *$ \\
\hline Cultivar & $* *$ & $* *$ & $* *$ \\
\hline Local $\times \mathrm{N}$ & Ns & * & Ns \\
\hline Local x Cultivar & $* *$ & $* *$ & $* *$ \\
\hline $\mathrm{N} \times$ Cultivar & $* *$ & Ns & * \\
\hline Local x N x Cultivar & Ns & * & ** \\
\hline Bloco (Local) & $* *$ & $* *$ & $* *$ \\
\hline C. V. (\%) & 7,7 & 6,0 & 9,3 \\
\hline
\end{tabular}

Médias seguidas pela mesma letra na vertical não diferem pelo teste Tukey $5 \%$

(2) $* \mathrm{e}^{* *}=$ significativo a $5 \%$ e $1 \%$ respectivamente, e $\mathrm{ns}=$ não significativo 
Tabela 33. Análise conjunta da produtividade, conteúdo e exportação de $\mathrm{N}$ nos grãos, em função de doses de nitrogênio e cultivar, em Votuporanga e Palmital nos anos agrícolas 1999/00 e 2000/01.

\begin{tabular}{|c|c|c|c|}
\hline Fatores da variação & Produtividade & N nos grãos & Exportação de $\mathrm{N}$ \\
\hline \multicolumn{4}{|l|}{ Nitrogênio, $\mathrm{kg} \mathrm{ha}^{-1}$} \\
\hline 0 & 4.182 & 12,4 & 51,8 \\
\hline 60 & 5.473 & 12,9 & 70,6 \\
\hline 120 & 5.895 & 14,1 & 83,9 \\
\hline 180 & 6.326 & 14,7 & 92,1 \\
\hline \multicolumn{4}{|l|}{ Cultivar $^{(1)}$} \\
\hline Tork & $5.889 \mathrm{a}$ & $13,1 \mathrm{~d}$ & $77,8 \mathrm{a}$ \\
\hline AG 1051 & $5.789 \mathrm{a}$ & $12,6 \mathrm{~d}$ & $73,8 \mathrm{ab}$ \\
\hline CO 9560 & $5.777 \mathrm{a}$ & $13,0 \mathrm{~cd}$ & $75,7 \mathrm{ab}$ \\
\hline C $333 \mathrm{~B}$ & $5.774 \mathrm{ab}$ & $13,9 b$ & $78,5 \mathrm{a}$ \\
\hline XL 251 & $5.770 \mathrm{ab}$ & 13,4 bc & $77,8 \mathrm{a}$ \\
\hline Dina 766 & $5.750 \mathrm{ab}$ & $13,2 \mathrm{~cd}$ & $76,3 \mathrm{a}$ \\
\hline Master & $5.669 \mathrm{ab}$ & $12,8 \mathrm{~cd}$ & 73,3 a-c \\
\hline BR 3123 & $5.425 \mathrm{~b}$ & $12,8 \mathrm{~d}$ & 70,4 bc \\
\hline 8410 & $4.835 \mathrm{c}$ & $15,3 \mathrm{a}$ & $74,6 \mathrm{ab}$ \\
\hline BR 4157 & $4.442 \mathrm{~d}$ & $15,2 \mathrm{a}$ & $68,0 \mathrm{c}$ \\
\hline \multirow[t]{2}{*}{ Média } & 5.492 & 13,5 & 75,6 \\
\hline & \multicolumn{3}{|c|}{$\mathrm{P}>\mathrm{F}^{(2)}$} \\
\hline Local & $* *$ & ** & $* *$ \\
\hline Nitrogênio & $* *$ & $* *$ & $* *$ \\
\hline Linear & $* *$ & $* *$ & $* *$ \\
\hline Quadrática & $* *$ & Ns & $* *$ \\
\hline Cultivar & $* *$ & $* *$ & $* *$ \\
\hline Local x N & $* *$ & $* *$ & $* *$ \\
\hline Local x Cultivar & $* *$ & $* *$ & $* *$ \\
\hline $\mathrm{N} \times$ Cultivar & $*$ & Ns & Ns \\
\hline $\begin{array}{l}\text { Local x N x Cultivar } \\
\text { Bloco (Local) }\end{array}$ & $\begin{array}{l}\text { Ns } \\
* *\end{array}$ & $\begin{array}{l}\text { Ns } \\
\text { Ns }\end{array}$ & $\begin{array}{l}\text { Ns } \\
*\end{array}$ \\
\hline C. V. $(\%)$ & 10,6 & 8,3 & 13,3 \\
\hline
\end{tabular}

(1) Médias seguidas pela mesma letra na vertical não diferem pelo teste Tukey $5 \% ; 2^{*} \mathrm{e}^{* *}=$ significativo a $5 \% \mathrm{e}$ $1 \%$ respectivamente, e ns = não significativo 
Estudou-se a resposta da produtividade e exportação de $\mathrm{N}$ das cultivares ao nitrogênio nas análises conjuntas, desconsiderando-se a interação local x cultivar (Figuras 17 e 18, Tabela 34)

Dentre as cultivares comuns nas duas análises, a D 766 foi a única que sempre respondeu linearmente ao nitrogênio, enquanto a BR 3123 apresentou resposta linear na análise conjunta 1998/99 e quadrática na 1999/00 e 2000/01. Entre as cultivares incluídas em apenas uma das análises, IAC V1, Tork e BR 4157 responderam linearmente ao nitrogênio. O simples fato da resposta ter sido linear ou quadrática não possibilita inferências sobre a magnitude da resposta da cultivar ao nitrogênio, ou seja, a cultivar com modelo linear não tem, necessariamente, maior resposta ao nitrogênio do que outra com modelo quadrático. Tomando-se como exemplo a 8410 e a BR 4157, cultivares que apresentaram produtividades semelhantes na testemunha e pouca adaptação aos ambientes na análise 1999/00 e 2000/01, verifica-se que o modelo linear e quadrático ajustaram melhor para a BR 4157 e a 8410 , respectivamente, mas a resposta ao nitrogênio foi maior na 8410 em relação à BR 4157.

A única cultivar que não respondeu à adubação nitrogenada foi a XL 212, que foi avaliada apenas em 1998/99. Duarte et al. (1998) também verificaram que a XL 212 não respondeu ao nitrogênio e produziu cerca de $8 \mathrm{Mg} \mathrm{ha}^{-1}$ na ausência de adubação nitrogendada em Cândido Mota.

Os cálculos do aumento relativo de produtividade para o máximo das equações de resposta da produtividade ao nitrogênio (Tabela 35) indicam que a IAC Vl foi a mais responsiva ao nitrogênio na análise conjunta 1998/99 e a BR 3123 e 8410, na análise 1999/00 e 2000/01. A cultivar XL 212 não respondeu ao N na análise 1998/99, como já citado, e a CO 9560 foi a menos responsiva ao N na análise 1999/00 e 2000/01. O fato da BR 3123 ter alta resposta ao nitrogênio em 1999/00 e 2000/01 e não ter se destacado em 1998/99, pode estar relacionado a sua baixa adaptação às condições ambientais predominantes em 1998/99. Isso demonstra, mais uma vez, a necessidade de escolher genótipos adaptados ao ambiente (clima, solo, época de semeadura, entre outros fatores) para o estudo da interação genótipo x nitrogênio. 

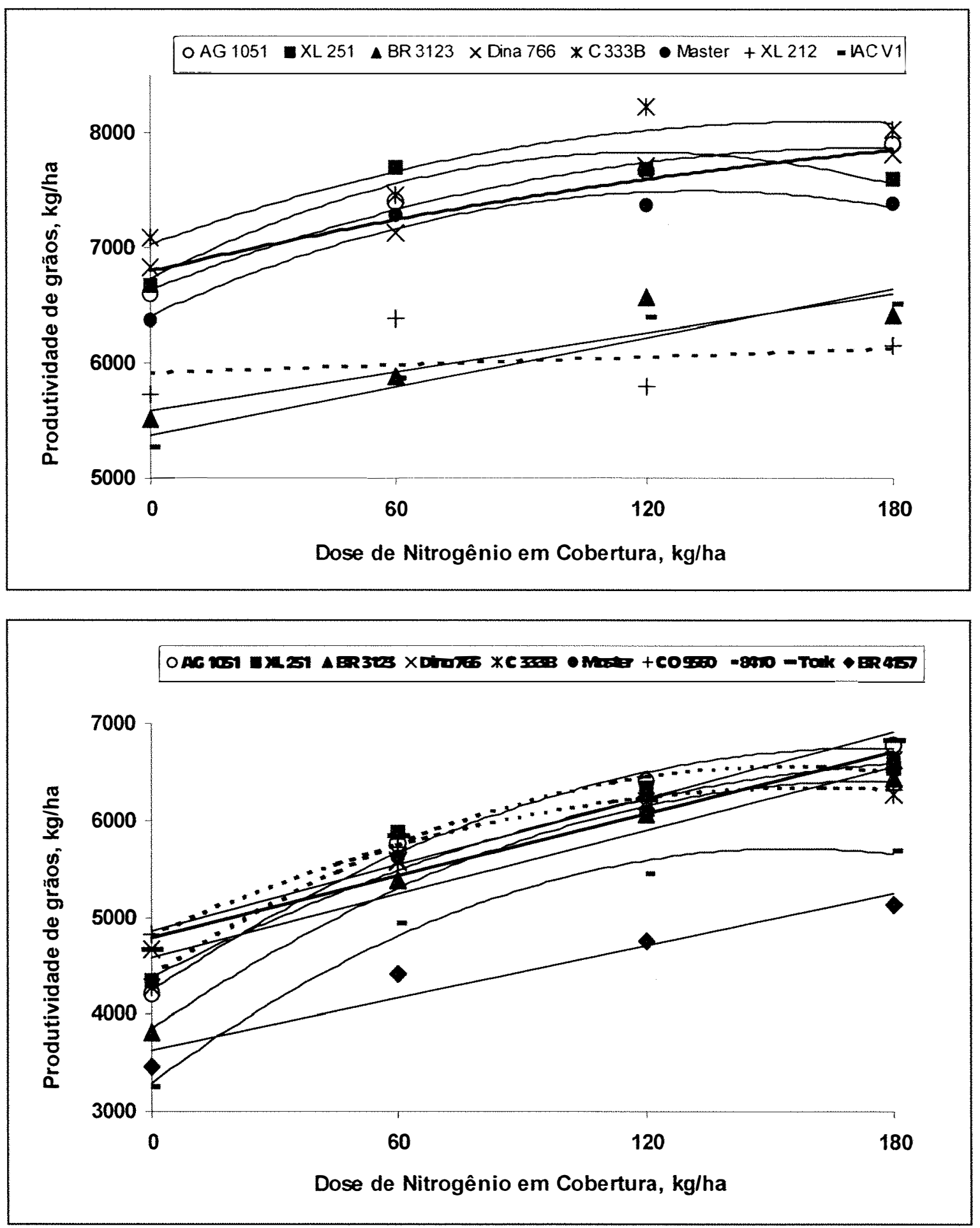

Figura 17- Produtividade de grãos em cultivares de milho, em função da adubação nitrogenada de cobertura, nas análises conjuntas de Votuporanga, Cândido Mota e Itapeva em 1998/99 e de Votuporanga e Palmital nos anos agrícolas $1999 / 00$ e 2000/2001. 

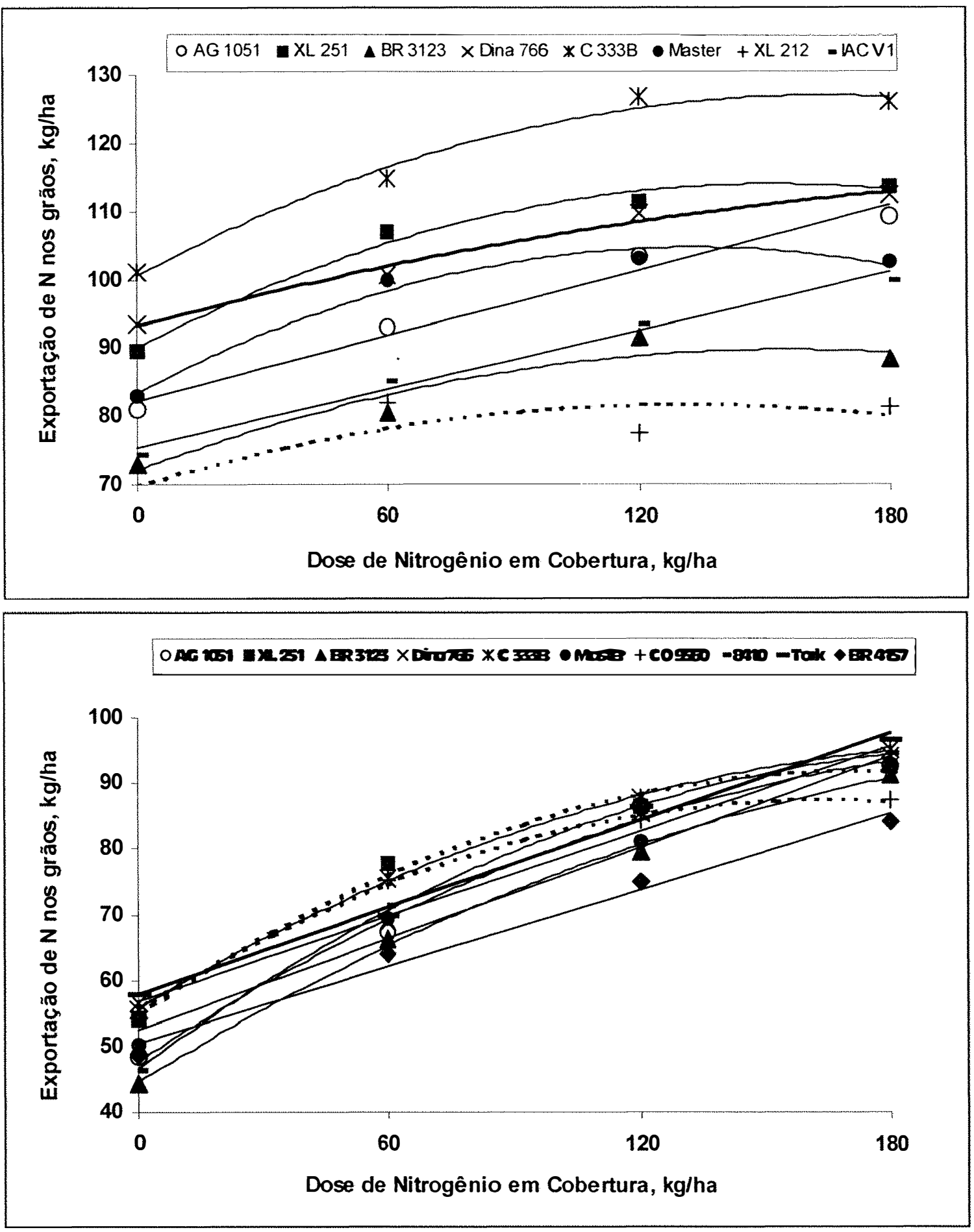

Figura 18- Exportação de $\mathrm{N}$ nos grãos em cultivares de milho, em função da adubação nitrogenada de cobertura, nas análises conjuntas de Votuporanga, Cândido Mota e Itapeva em 1998/99 e de Votuporanga e Palmital nos anos agrícolas $1999 / 00$ e 2000/2001. 
Tabela 34. Equações de regressão da produtividade de grãos e exportação de $\mathrm{N}$ nos grãos, em função das doses de nitrogênio em cobertura, nas análises conjuntas do subprojeto "Resposta de Genótipos de Milho ao Nitrogênio" (1).

\begin{tabular}{llllll}
\hline \multirow{2}{*}{ Cultivar } & \multicolumn{2}{c}{ Produtividade } & & \multicolumn{2}{c}{$N$ exportação } \\
\cline { 2 - 3 } \cline { 4 - 5 } & Equação & $\mathrm{r}^{2}$ & & Equação & $\mathrm{r}^{2}$ \\
\hline
\end{tabular}

\section{8/99 Itapeva, Cândido Mota e Votuporanga}

$\begin{array}{lllll}\text { AG1051 } & Y=6632+13,98 x-0,039 x^{2} & 0,99 & Y=82,3+0,16 x & 0,98 \\ \text { XL 251 } & Y=6724+18,50 x-0,077 x^{2} & 0,94 & Y=90,1+0,32 x-0,001 x^{2} & 0,98 \\ \text { BR 3123 } & Y=5590+5,63 x & 0,80 & Y=72,1+0,23 x-0,0007 x^{2} & 0,93 \\ \text { D 766 } & Y=6843+5,87 x & 0,94 & Y=94,3+0,11 x & 0,96 \\ \text { C 333B } & Y=7025+13,08 x-0,040 x^{2} & 0,87 & Y=100,6+0,32 x-0,0012 x^{2} & 0,99 \\ \text { Master } & Y=6405+16,46 x-0,062 x^{2} & 0,96 & Y=83,5+0,32 x-0,001 x^{2} & 0,98 \\ \text { XL 212 } & Y=5909+1,20 x & 0,09^{\text {ns }} & Y=69,7+0,18 x-0,0007 x^{2} & 0,71 \\ \text { IAC V1 } & Y=5376+7,07 x & 0,93 & Y=75,5+0,14 x & 0,99\end{array}$

1999/00 e 2000/01 Palmital e Votuporanga

$\begin{array}{lllll}\text { AG1051 } & \mathrm{Y}=4244+28,49 \mathrm{x}-0,081 \mathrm{x}^{2} & 0,99 & \mathrm{Y}=47,9+0,412 \mathrm{x}-0,0009 \mathrm{x}^{2} & 0,99 \\ \text { XL 251 } & \mathrm{Y}=4385+28,17 \mathrm{x}-0,091 \mathrm{x}^{2} & 0,99 & \mathrm{Y}=54,7+0,427 \mathrm{x}-0,001 \mathrm{x}^{2} & 0,99 \\ \text { BR 3123 } & \mathrm{Y}=3847+29,13 \mathrm{x}-0,083 \mathrm{x}^{2} & 1,00 & \mathrm{Y}=44,7+0,388 \mathrm{x}-0,0007 \mathrm{x}^{2} & 1,00 \\ \text { D 766 } & \mathrm{Y}=4788+10,69 \mathrm{x} & 0,97 & \mathrm{Y}=56,9+0,215 \mathrm{x} & 0,99 \\ \text { C 333B } & \mathrm{Y}=4277+26,35 \mathrm{x}-0,085 \mathrm{x}^{2} & 1,00 & \mathrm{Y}=55,9+0,373 \mathrm{x}-0,0009 \mathrm{x}^{2} & 1,00 \\ \text { Master } & \mathrm{Y}=4379+21,44 \mathrm{x}-0,051 \mathrm{x}^{2} & 0,98 & \mathrm{Y}=52,4+0,231 \mathrm{x} & 0,98 \\ \text { CO 9560 } & \mathrm{Y}=4810+18,99 \mathrm{x}-0,059 \mathrm{x}^{2} & 1,00 & \mathrm{Y}=55,6+0,387 \mathrm{x}-0,001 \mathrm{x}^{2} & 1,00 \\ \text { 8410 } & \mathrm{Y}=3295+31,22 \mathrm{x}-0,101 \mathrm{x}^{2} & 0,99 & \mathrm{Y}=46,7+0,466 \mathrm{x}-0,001 \mathrm{x}^{2} & 1,00 \\ \text { Tork } & \mathrm{Y}=4857+11,47 \mathrm{x} & 0,95 & \mathrm{Y}=57,9+0,221 \mathrm{x} & 0,99 \\ \text { BR 4157 } & \mathrm{Y}=3635+8,94 \mathrm{x} & 0,93 & \mathrm{Y}=50,4+0,196 \mathrm{x} & 0,99\end{array}$


Tabela 35. Produtividade máxima de grãos em cultivares de milho, doses de nitrogênio em cobertura correspondentes à produtividade máxima e aumento relativo da produtividade nas análises conjuntas do subprojeto "Resposta de Genótipos de Milho ao Nitrogênio"

\begin{tabular}{lccc}
\hline Cultivar & \multicolumn{2}{c}{ Produtividade máxima } & $\begin{array}{c}\text { Aumento relativo } \\
\text { de produtividade }\end{array}$ \\
\cline { 2 - 3 } & Valor & Dose de N & 19 \\
AG 1051 & $\mathbf{1 9 9 8 / 9 9}$ & Itapeva, Cândido Mota e Votuporanga \\
XL 251 & 7884 & 179 & 17 \\
BR 3123 & 7835 & 120 & 18 \\
D 766 & 6603 & 180 & 15 \\
C 333B & 7900 & 180 & 15 \\
Master & 8094 & 164 & 17 \\
XL 212 & 7497 & 133 & 4 \\
IAC V1 & 6125 & 180 & 24
\end{tabular}

1999/00 e 2000/01 Palmital e Votuporanga

$\begin{array}{llll}\text { AG 1051 } & 6749 & 176 & 59 \\ \text { XL 251 } & 6565 & 155 & 50 \\ \text { BR 3123 } & 6403 & 175 & 66 \\ \text { D 766 } & 6712 & 180 & 40 \\ \text { C 333B } & 6314 & 155 & 48 \\ \text { Master } & 6586 & 180 & 50 \\ \text { CO 9560 } & 6338 & 161 & 32 \\ 8410 & 5708 & 154 & 73 \\ \text { Tork } & 6922 & 180 & 43 \\ \text { BR 4157 } & 5234 & 180 & 44\end{array}$

-7T) A partir dos valores estimados pelo modelo matemático, utilizando a dose máxima quando o valor extrapolou o intervalo estudado. 
São apresentados os resultados de resposta da exportação de $\mathrm{N}$ das cultivares ao nitrogênio para as duas análises conjuntas, embora as diferenças não tenham sido significativas em 1999/00 e 2000/01 (Figura 18, Tabela 34). Em 1998/99, os maiores aumentos de exportação de $\mathrm{N}$ nos grãos com a adubação nitrogenada ocorreram nas cultivares AG 1051, XL 251, C 333B e Master.

Conclui-se que a experimentação em um único local e ano pode levar a conclusões equivocadas sobre a magnitude do requerimento do cultivar quanto à adubação nitrogenada. De maneira geral, a diferenciação dos cultivares é discreta, com ressalvas para casos específicos, como a XL 212 (pouco responsiva), IAC Vl, BR 3123 e 8410 (muito responsivas)

\subsection{Subprojeto Parcelamento}

Não se verificou sintomas de fitoxicidade de fertilizantes nas parcelas adubadas com $60 \mathrm{~kg} \mathrm{ha}^{-1}$ de nitrogênio no sulco de semeadura por ocasião da emergência das plantas.

De maneira semelhante ao Subprojeto Genótipos x Nitrogênio, houve efeito signficativo para genótipo e adubação nitrogenada para todos os parâmetros avaliados (Tabela 36). Novamente, constatou-se interação entre genótipo e nitrogênio, exceto para o teor de nitrogênio nos grãos em Votuporanga em produtividade em Cândido Mota.

As cultivares C 333B e Master destacaram-se quanto à produtividade de grãos nos dois locais e à exportação de nitrogênio nos grãos em Votuporanga (Tabelas 37 a 41). Para esses mesmos parâmetros, a XL 212 foi semelhante e inferior à BR 3123 em Cândido Mota e Votuporanga, respectivamente. A C 333B apresentou os maiores teores de $\mathrm{N}$ nos grãos e nas folhas. Corroborando com os resultados obtidos no Subprojeto 1, a XL 212 teve os menores teores de $\mathrm{N}$ nos grãos.

A análise estatística do efeito do nitrogênio através de contrastes ortogonais evidenciou que em Cândido Mota a forma de aplicação do nitrogênio não influenciou a produtividade do milho; apenas os teores de $\mathrm{N}$ nas fohas, no estádio de início de formação de grãos, foram alterados. O aumento de produtividade foi pouco pronunciado, e o 


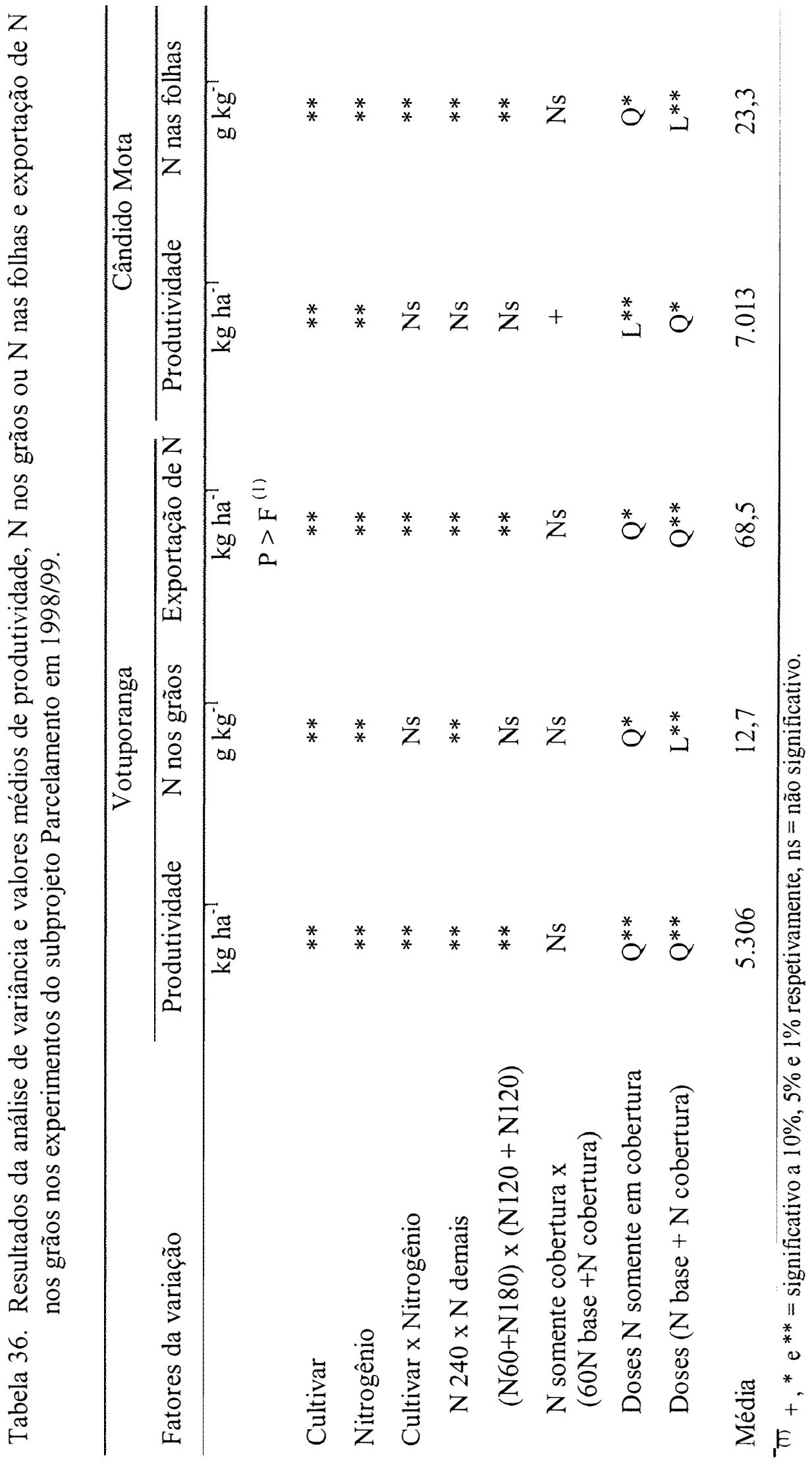


Tabela 37. Produtividade média de cultivares de milho em função da aplicação de nitrogênio em diferentes modos e doses em Votuporanga (SP), em 1998/99

\begin{tabular}{|c|c|c|c|c|c|c|}
\hline \multicolumn{2}{|c|}{ Nitrogênio } & \multicolumn{5}{|c|}{ Cultivar } \\
\hline Dose & Parcelamento & BR 3123 & XL 212 & C $333 \mathrm{~B}$ & Master & Média \\
\hline & & \multicolumn{5}{|c|}{ 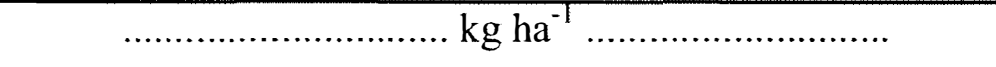 } \\
\hline 0 & $0+0$ & 3.146 & 3.253 & 3.404 & 3.241 & 3.261 \\
\hline 0 & $0+0$ & 3.024 & 3.196 & 3.589 & 3.351 & 3.290 \\
\hline 60 & $0+60$ & 4.037 & 3.910 & 5.958 & 4.461 & 4.592 \\
\hline 120 & $0+120$ & 4.363 & 4.001 & 6.241 & 5.519 & 5.031 \\
\hline 180 & $0+180$ & 4.593 & 3.954 & 6.358 & 5.267 & 5.043 \\
\hline 60 & $60+0$ & 5.396 & 4.307 & 5.574 & 5.692 & 5.342 \\
\hline 120 & $60+60$ & 6.910 & 5.055 & 7.338 & 6.690 & 6.498 \\
\hline 180 & $60+120$ & 6.467 & 5.400 & 7.802 & 7.134 & 6.701 \\
\hline 240 & $60+180$ & 5.999 & 5.083 & 7.785 & 7.146 & 6.503 \\
\hline \multirow[t]{2}{*}{240} & $120+120$ & 6.709 & 5.394 & 7.885 & 7.203 & 6.798 \\
\hline & & \multicolumn{5}{|c|}{$P>F^{(2)}$} \\
\hline \multicolumn{2}{|c|}{ N $240 \times$ demais } & $* *$ & $* *$ & $* *$ & $* *$ & $* *$ \\
\hline \multicolumn{2}{|c|}{$(\mathrm{N} 60+180) \times(\mathrm{N} 120+120)$} & $* *$ & $* *$ & $* *$ & $* *$ & $* *$ \\
\hline \multicolumn{2}{|c|}{$\begin{array}{l}N \text { somente cobertura } x \\
(\mathrm{~N} 60 \text { base }+N \text { cobertura) }\end{array}$} & + & Ns & ns & ns & Ns \\
\hline \multicolumn{2}{|c|}{ Doses $\mathrm{N}$ cobertura } & $\mathrm{L}^{* *}$ & Ns & $\mathrm{Q}^{* *}$ & $\mathrm{Q}^{* *}$ & $\mathrm{Q}^{* *}$ \\
\hline \multicolumn{2}{|c|}{ Doses (base + cobertura) } & $\mathrm{Q}^{* *}$ & $\mathrm{Q}^{*}$ & $\mathrm{Q}^{* *}$ & $\mathrm{Q}^{* *}$ & $\mathrm{Q}^{* *}$ \\
\hline \multicolumn{2}{|c|}{ Média ${ }^{(1)}$} & $5.064 \mathrm{c}$ & $4.395 \mathrm{~d}$ & $6.193 \mathrm{a}$ & $5.570 \mathrm{~b}$ & 5.306 \\
\hline
\end{tabular}


Tabela 38. Conteúdo de nitrogênio nos grãos de cultivares de milho semeadas em Votuporanga, em 1998/99, em função de doses de nitrogênio

\begin{tabular}{|c|c|c|c|c|c|c|}
\hline \multicolumn{2}{|c|}{ Nitrogênio } & \multicolumn{5}{|c|}{ Cultivar } \\
\hline Dose & Parcelamento & BR 3123 & XL 212 & C 333 B & Master & Média \\
\hline & & \multicolumn{5}{|c|}{ 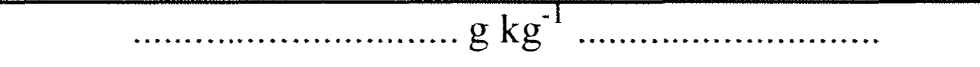 } \\
\hline 0 & $0+0$ & 13,1 & 10,3 & 12,7 & 14,0 & 12,5 \\
\hline 0 & $0+0$ & 12,4 & 11,7 & 12,3 & 12,7 & 12,2 \\
\hline 60 & $0+60$ & 11,5 & 12,0 & 13,2 & 11,3 & 12,0 \\
\hline 120 & $0+120$ & 13,0 & 11,5 & 14,0 & 12,9 & 12,8 \\
\hline 180 & $0+180$ & 13,5 & 12,7 & 15,0 & 13,0 & 13,6 \\
\hline 60 & $60+0$ & 11,2 & 10,9 & 13,4 & 12,0 & 11,9 \\
\hline 120 & $60+60$ & 11,8 & 11,8 & 14,1 & 12,2 & 12,5 \\
\hline 180 & $60+120$ & 12,7 & 11,7 & 14,8 & 13,2 & 13,1 \\
\hline 240 & $60+180$ & 13,0 & 12,5 & 14,4 & 13,2 & 13,3 \\
\hline \multirow[t]{2}{*}{240} & $120+120$ & 13,6 & 12,5 & 15,5 & 12,5 & 13,5 \\
\hline & & \multicolumn{5}{|c|}{$\mathrm{P}>\mathrm{F}^{(2)}$} \\
\hline \multicolumn{2}{|c|}{ N $240 \times$ demais } & - & - & - & - & $* *$ \\
\hline \multicolumn{2}{|c|}{$(\mathrm{N} 60+180) \times(\mathrm{N} 120+120)$} & - & - & - & - & ns \\
\hline \multicolumn{2}{|c|}{$\begin{array}{l}N \text { somente cobertura } x \\
(\mathrm{~N} 60 \text { base }+N \text { cobertura })\end{array}$} & - & - & - & - & ns \\
\hline \multicolumn{2}{|c|}{ Doses $N$ cobertura } & - & - & - & - & $\mathrm{Q}^{*}$ \\
\hline \multicolumn{2}{|c|}{ Doses (base + cobertura) } & - & - & - & - & $\mathrm{L}^{* *}$ \\
\hline \multicolumn{2}{|c|}{ Média (1) } & $12,6 \mathrm{~b}$ & $11,7 \mathrm{c}$ & $13,9 \mathrm{a}$ & $12,7 \mathrm{~b}$ & 12,7 \\
\hline
\end{tabular}


Tabela 39. Nitrogênio exportado pelos grãos em cultivares de milho semeadas em Votuporanga, em 1998/99, em função de doses de nitrogênio

\begin{tabular}{|c|c|c|c|c|c|c|}
\hline \multicolumn{2}{|c|}{ Nitrogênio } & \multicolumn{5}{|c|}{ Cultivar } \\
\hline Dose & Parcelamento & BR 3123 & XL 212 & C $333 \mathrm{~B}$ & Master & Média \\
\hline & & \multicolumn{5}{|c|}{ 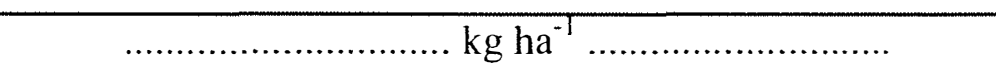 } \\
\hline 0 & $0+0$ & 41,3 & 33,3 & 43,7 & 45,3 & 40,9 \\
\hline 0 & $0+0$ & 37,5 & 37,1 & 44,2 & 41,8 & 40,2 \\
\hline 60 & $0+60$ & 46,4 & 46,7 & 79,1 & 50,5 & 55,7 \\
\hline 120 & $0+120$ & 56,2 & 46,1 & 87,5 & 70,5 & 65,1 \\
\hline 180 & $0+180$ & 61,5 & 50,1 & 95,9 & 68,8 & 69,1 \\
\hline 60 & $60+0$ & 61,1 & 51,3 & 74,8 & 68,4 & 63,9 \\
\hline 120 & $60+60$ & 81,8 & 59,8 & 103,5 & 82,4 & 81,9 \\
\hline 180 & $60+120$ & 81,9 & 63,1 & 115,5 & 93,8 & 88,6 \\
\hline 240 & $60+180$ & 77,9 & 63,7 & 112,1 & 93,8 & 86,9 \\
\hline \multirow[t]{2}{*}{240} & $120+120$ & 91,3 & 67,2 & 121,8 & 89,8 & 92,5 \\
\hline & & \multicolumn{5}{|c|}{$\mathrm{P}>\mathrm{F}^{(2)}$} \\
\hline \multicolumn{2}{|c|}{ N $240 \times$ demais } & $* *$ & $* *$ & $* *$ & $* *$ & $* *$ \\
\hline \multicolumn{2}{|c|}{$(\mathrm{N} 60+180) \times(\mathrm{N} 120+120)$} & $* *$ & $* *$ & $*$ & $* *$ & $* *$ \\
\hline \multicolumn{2}{|c|}{$\begin{array}{l}N \text { somente cobertura } x \\
(\mathrm{~N} 60 \text { base }+N \text { cobertura) }\end{array}$} & ns & Ns & ns & ns & ns \\
\hline \multicolumn{2}{|c|}{ Doses $N$ cobertura } & $\mathrm{L}^{* *}$ & $\mathrm{~L}^{*}$ & $\mathrm{Q}^{* *}$ & $\mathrm{~L}^{* *}$ & $\mathrm{Q}^{*}$ \\
\hline \multicolumn{2}{|c|}{ Doses (base + cobertura) } & $\mathrm{Q}^{* *}$ & $\mathrm{~L} * *$ & $\mathrm{~L}^{* *}$ & $\mathrm{~L}^{* *}$ & $\mathrm{Q}^{* *}$ \\
\hline \multicolumn{2}{|c|}{ Média ${ }^{(1)}$} & $63,7 \mathrm{c}$ & $51,8 \mathrm{~d}$ & $87,8 \mathrm{a}$ & $70,5 \mathrm{~b}$ & 68,5 \\
\hline
\end{tabular}


Tabela 40. Produtividade de cultivares de milho semeadas em Cândido Mota, em 1998/99, em função da aplicação de nitrogênio em diferentes modos e doses

\begin{tabular}{|c|c|c|c|c|c|c|}
\hline \multicolumn{2}{|c|}{ Nitrogênio } & \multicolumn{5}{|c|}{ Cultivar } \\
\hline \multirow[t]{2}{*}{ Dose } & Parcelamento & BR 3123 & XL 212 & C $333 \mathrm{~B}$ & Master & Média \\
\hline & & \multicolumn{5}{|c|}{$\mathrm{kg} \mathrm{ha}^{-1} \ldots \ldots \ldots \ldots \ldots \ldots \ldots \ldots \ldots \ldots \ldots \ldots \ldots \ldots$} \\
\hline 0 & $0+0$ & 5.875 & 5.744 & 7.276 & 6.621 & 6.379 \\
\hline 0 & $0+0$ & 5.476 & 6.288 & 6.733 & 6.679 & 6.294 \\
\hline 60 & $0+60$ & 5.485 & 6.487 & 7.157 & 6.679 & 6.452 \\
\hline 120 & $0+120$ & 7.263 & 6.832 & 7.705 & 8.042 & 7.460 \\
\hline 180 & $0+180$ & 7.404 & 6.081 & 7.585 & 8.242 & 7.328 \\
\hline 60 & $60+0$ & 6.273 & 6.339 & 7.987 & 8.143 & 7.186 \\
\hline 120 & $60+60$ & 6.803 & 6.532 & 7.818 & 8.335 & 7.372 \\
\hline 180 & $60+120$ & 7.040 & 5.778 & 8.143 & 8.799 & 7.440 \\
\hline 240 & $60+180$ & 6.810 & 5.974 & 8.225 & 8.373 & 7.346 \\
\hline \multirow[t]{2}{*}{240} & $120+120$ & 6.651 & 5.989 & 7.296 & 7.548 & 6.871 \\
\hline & & \multicolumn{5}{|c|}{$\mathrm{P}>\mathrm{F}^{(2)}$} \\
\hline \multirow{2}{*}{\multicolumn{2}{|c|}{$\begin{array}{l}\text { N } 240 \times \text { demais } \\
(\mathrm{N} 60+180) \times(\mathrm{N} 120+120)\end{array}$}} & - & - & - & - & ns \\
\hline & & - & - & - & - & ns \\
\hline \multicolumn{2}{|c|}{$\begin{array}{l}N \text { somente cobertura } x \\
(N 60 \text { base }+N \text { cobertura) }\end{array}$} & - & - & - & - & ns \\
\hline \multicolumn{2}{|c|}{ Doses $N$ cobertura } & - & - & - & - & $\mathrm{L} * *$ \\
\hline \multicolumn{2}{|c|}{ Doses (base + cobertura) } & - & - & - & - & $\mathrm{Q}^{*}$ \\
\hline \multicolumn{2}{|c|}{ Média ${ }^{(1)}$} & $6.508 \mathrm{~b}$ & $6.205 \mathrm{~b}$ & $7.593 \mathrm{a}$ & $7.746 \mathrm{a}$ & 7.013 \\
\hline
\end{tabular}

(T) C. V. $=9,3 \%$, médias seguidas pela mesma letra na horizontal não diferem entre si pelo teste Tukey a $5 \%$ de probabilidade

(2) Teste $\mathrm{F}$ para cultivar significativo $1 \% \mathrm{e}$ interação cultivar $\mathrm{x}$ nitrogênio não significativo, * $\mathrm{e}^{* *}=$ significativo a $5 \%$ e $1 \%$, respetivamente, e ns = não significativo 
Tabela 41. Conteúdo de nitrogênio nas folhas de cultivares de milho semeadas em Cândido Mota, em 1998/99, em função da aplicação de nitrogênio em diferentes modos e doses

\begin{tabular}{|c|c|c|c|c|c|c|}
\hline \multicolumn{2}{|c|}{ Nitrogênio } & \multicolumn{5}{|c|}{ Cultivar } \\
\hline Dose & Parcelamento & BR 3123 & XL 212 & C $333 \mathrm{~B}$ & Master & Média \\
\hline & & \multicolumn{5}{|c|}{ 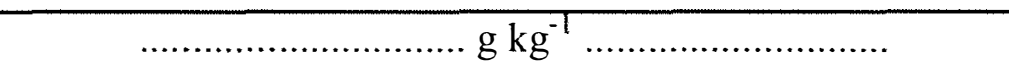 } \\
\hline 0 & $0+0$ & 16,9 & 21,7 & 23,7 & 18,5 & 20,2 \\
\hline 0 & $0+0$ & 16,7 & 20,4 & 23,8 & 19,1 & 20,0 \\
\hline 60 & $0+60$ & 20,8 & $22,9^{\circ}$ & 23,3 & 22,7 & 22,4 \\
\hline 120 & $0+120$ & 23,4 & 26,4 & 26,1 & 24,9 & 25,2 \\
\hline 180 & $0+180$ & 22,9 & 25,3 & 28,1 & 25,7 & 25,5 \\
\hline 60 & $60+0$ & 21,7 & 22,5 & 23,0 & 21,2 & 22,1 \\
\hline 120 & $60+60$ & 21,5 & 23,7 & 22,9 & 23,6 & 22,9 \\
\hline 180 & $60+120$ & 21,0 & 27,0 & 24,3 & 23,1 & 23,9 \\
\hline 240 & $60+180$ & 24,4 & 23,9 & 27,3 & 25,7 & 25,3 \\
\hline \multirow[t]{2}{*}{240} & $120+120$ & 25,0 & 25,6 & 26,8 & 24,7 & 25,6 \\
\hline & & \multicolumn{5}{|c|}{$\mathrm{P}>\mathrm{F}^{(2)}$} \\
\hline \multirow{2}{*}{\multicolumn{2}{|c|}{$\begin{array}{l}\text { N } 240 \times \text { demais } \\
(\mathrm{N} 60+180) \times(\mathrm{N} 120+120)\end{array}$}} & $* *$ & Ns & $* *$ & $* *$ & $* *$ \\
\hline & & ns & Ns & $* *$ & Ns & $* *$ \\
\hline \multicolumn{2}{|c|}{$\begin{array}{l}N \text { somente cobertura } x \\
(\mathrm{~N} 60 \text { base }+N \text { cobertura) }\end{array}$} & ns & Ns & ns & Ns & + \\
\hline \multicolumn{2}{|c|}{ Doses $\mathrm{N}$ cobertura } & $\mathrm{Q}^{* *}$ & $\mathrm{~L}^{* *}$ & $\mathrm{Q}^{*}$ & $\mathrm{~L}^{* *}$ & $\mathrm{Q}^{*}$ \\
\hline \multicolumn{2}{|c|}{ Doses (base + cobertura) } & $\mathrm{Q}^{* *}$ & $\mathrm{~L}^{* *}$ & ns & $\mathrm{L}^{* *}$ & $\mathrm{~L}^{* *}$ \\
\hline \multicolumn{2}{|c|}{ Média ${ }^{(1)}$} & $21,4 \mathrm{c}$ & $23,9 \mathrm{ab}$ & $24,9 \mathrm{a}$ & $22,9 \mathrm{bc}$ & 23,3 \\
\hline
\end{tabular}




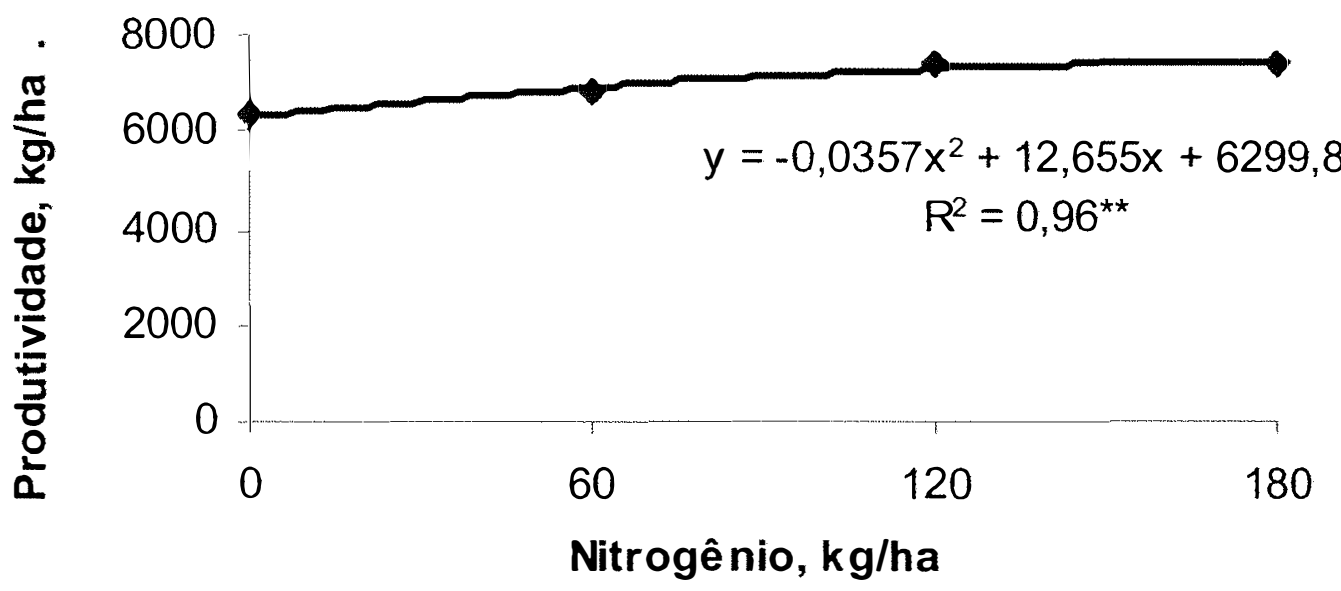

Figura 19- Produtividade média do milho em função de doses de fertilizante nitrogenado em Cândido Mota (SP), no ano agrícola 1998/99 (média de dois modos de parcelamento e quatro genótipos)

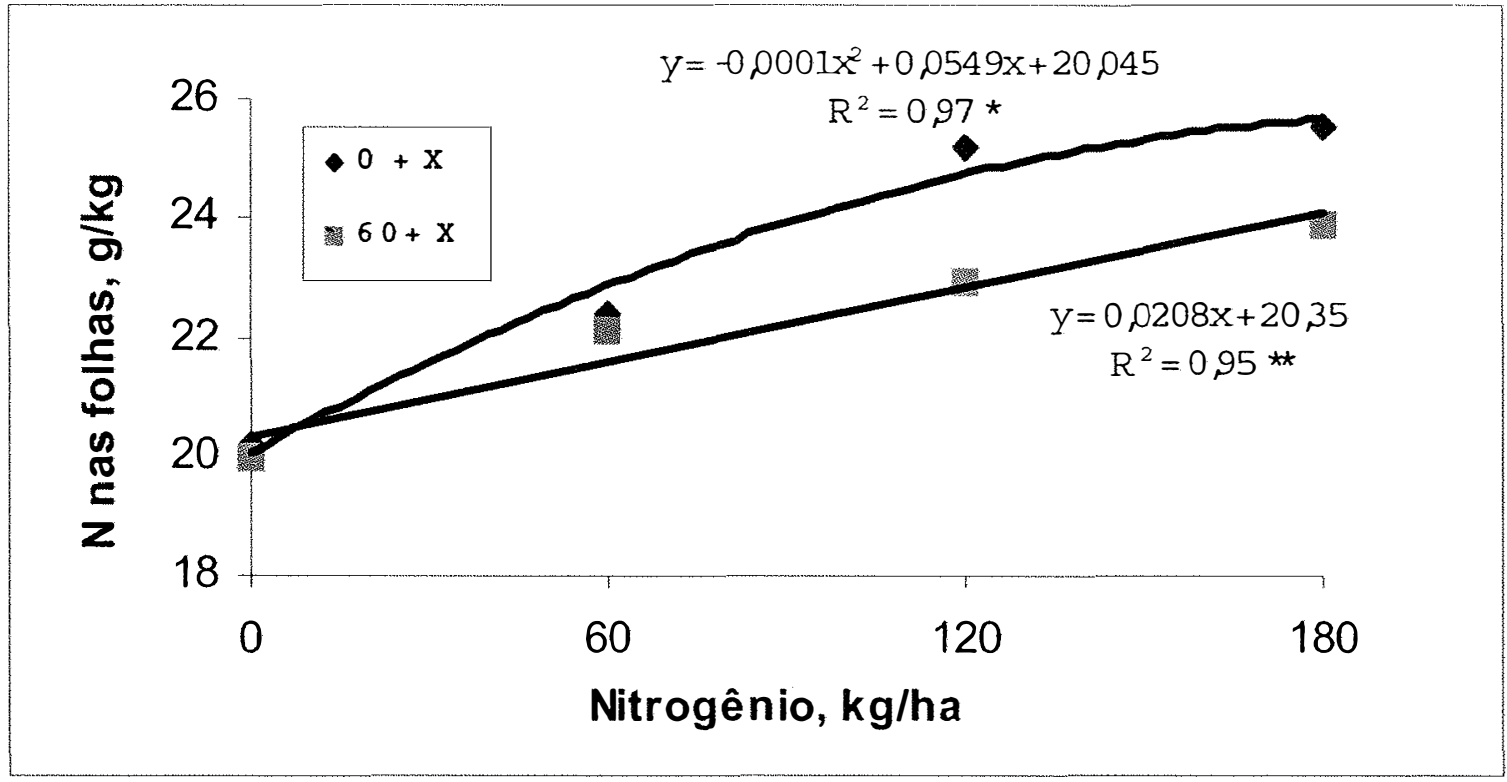

Figura 20- Conteúdo de nitrogênio em folhas de milho no início do enchimento de grãos em função de doses de fertilizante nitrogenado aplicado apenas em cobertura $(0+X)$ ou na semeadura mais cobertura $(60+X)$ em Cândido Mota, nos anos agrícolas 1998/99 (Média de quatro genótipos) 
ponto de máximo ocorreu na dose $177 \mathrm{~kg} \mathrm{ha}^{-1}$, proporcionando aumento relativo de $18 \%$ na produtividade (Figura 19). Os teores de $\mathrm{N}$ na folha foram maiores quando se aplicou todo o nitrogênio em cobertura do que quando se aplicaram $60 \mathrm{~kg} \mathrm{ha}^{-1}$ no sulco de semeadura + adubação de cobertura (Figura 20). Esses resultados são coerentes com os de N no solo apresentados anteriormente, em que se observou maiores valores de N-nitrato e $\mathrm{N}$ inorgânico quando a dose $60 \mathrm{~kg}$ ha-1 foi aplicada toda em cobertura em comparação com o seu emprego exclusivo no sulco de semeadura.

Em Votuporanga, onde os teores de $\mathrm{N}$ no solo foram muito baixos, o emprego do nitrogênio na semeadura e na cobertura resultou em maior produtividade de grãos e exportação de nitrogênio do que a aplicação apenas em cobertura, sendo este efeito dependente da cultivar (Figuras 21 e 22, Anexos 3 e 4).

A cultivar BR 3123 foi a que apresentou a maior diferença nas curvas de resposta ao $\mathrm{N}$ entre os dois modos de parcelamento: $130 \%$ de aumento relativo da produtividade com $60 \mathrm{~kg} \mathrm{ha}^{-1}$ na semeadura + cobertura contra apenas $42 \%$ omitindo o nitrogênio na semeadura (Figura 21). A BR 3123 foi também a única cultivar que apresentou maior produtividade com o aumento da dose de $\mathrm{N}$ na semeadura de 60 para $120 \mathrm{~kg} \mathrm{ha}^{-1}$ (signficativo a $10 \%$ ), confirmando seu maior requerimento por nitrogênio nos estádios iniciais de desenvolvimento.

A C 333B apresentou a maior resposta da produtividade de grãos à adubação nitrogendada e a menor variação na produtividade entre os tratamentos sem e com nitrogênio na semeadura. O XL 212 foi a menos responsiva ao nitrogênio $(70 \%$ de aumento relativo de produtividade, considerando a curva de resposta com $60 \mathrm{~kg} \mathrm{ha}^{-1}$ de $\mathrm{N}$ na semeadura).

A exportação de nitrogênio seguiu tendência similar à da produtividade de grãos, evidenciando-se, mais uma vez, que a C 333B foi a mais responsiva à adubação nitrogenada e pouco sensível ao seu modo de aplicação (Figura 22).

O conteúdo de $\mathrm{N}$ nos grãos aumentou de maneira semelhante para todos os cultivares e modos de parcelamento (Figura 23).

Os resultados sugerem que os cultivares de milho presentes no comércio apresentam, além de diferentes respostas à adubação nitrogenada, diferentes padrões de exi 

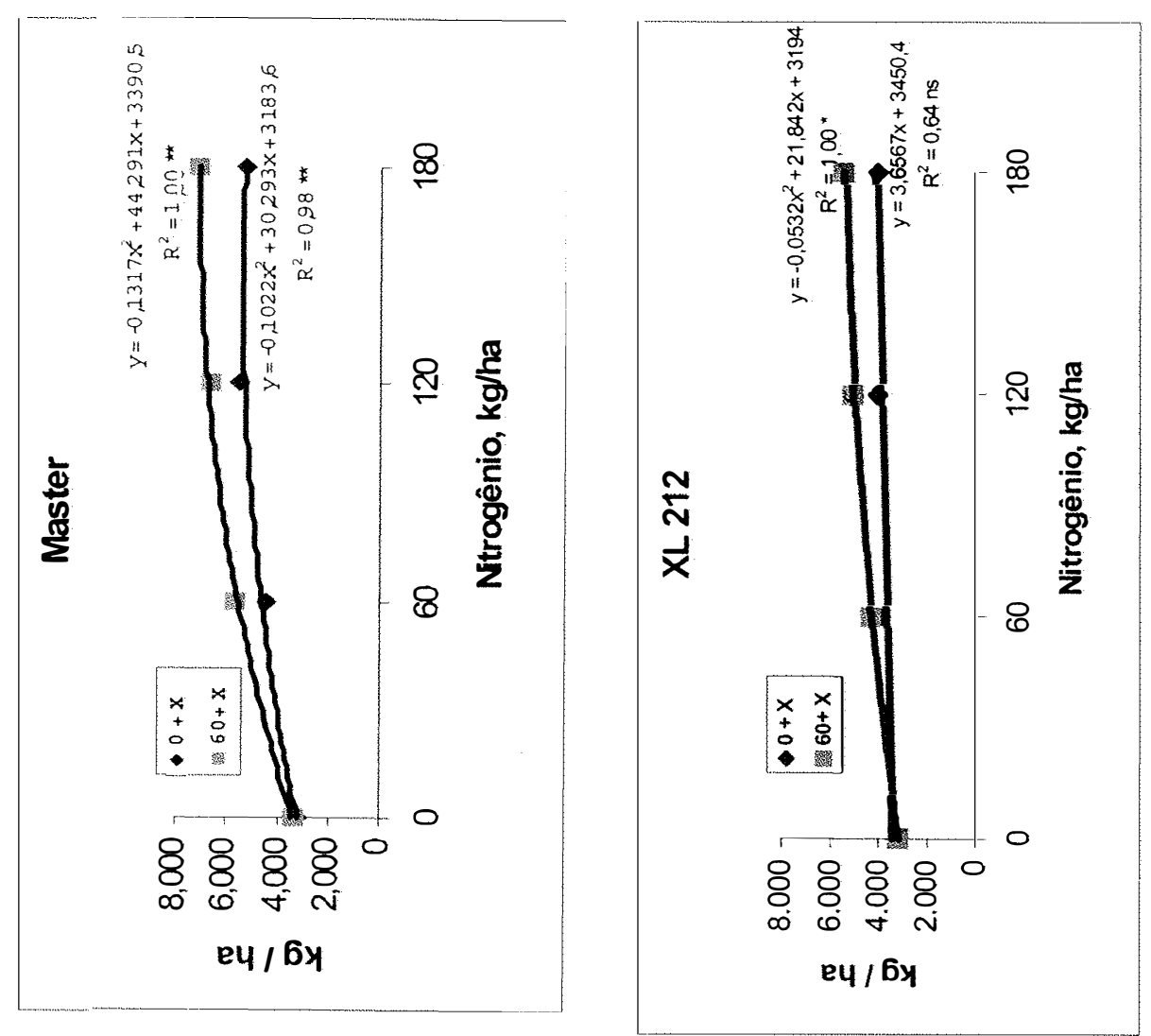

용

วี ธ్ષీ

爻离

氙

훌

5
0
0
0
0
0
0

迅

$\stackrel{\square}{\square}$

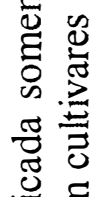

을 잉

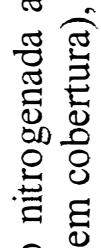

if

语

苂

శृ
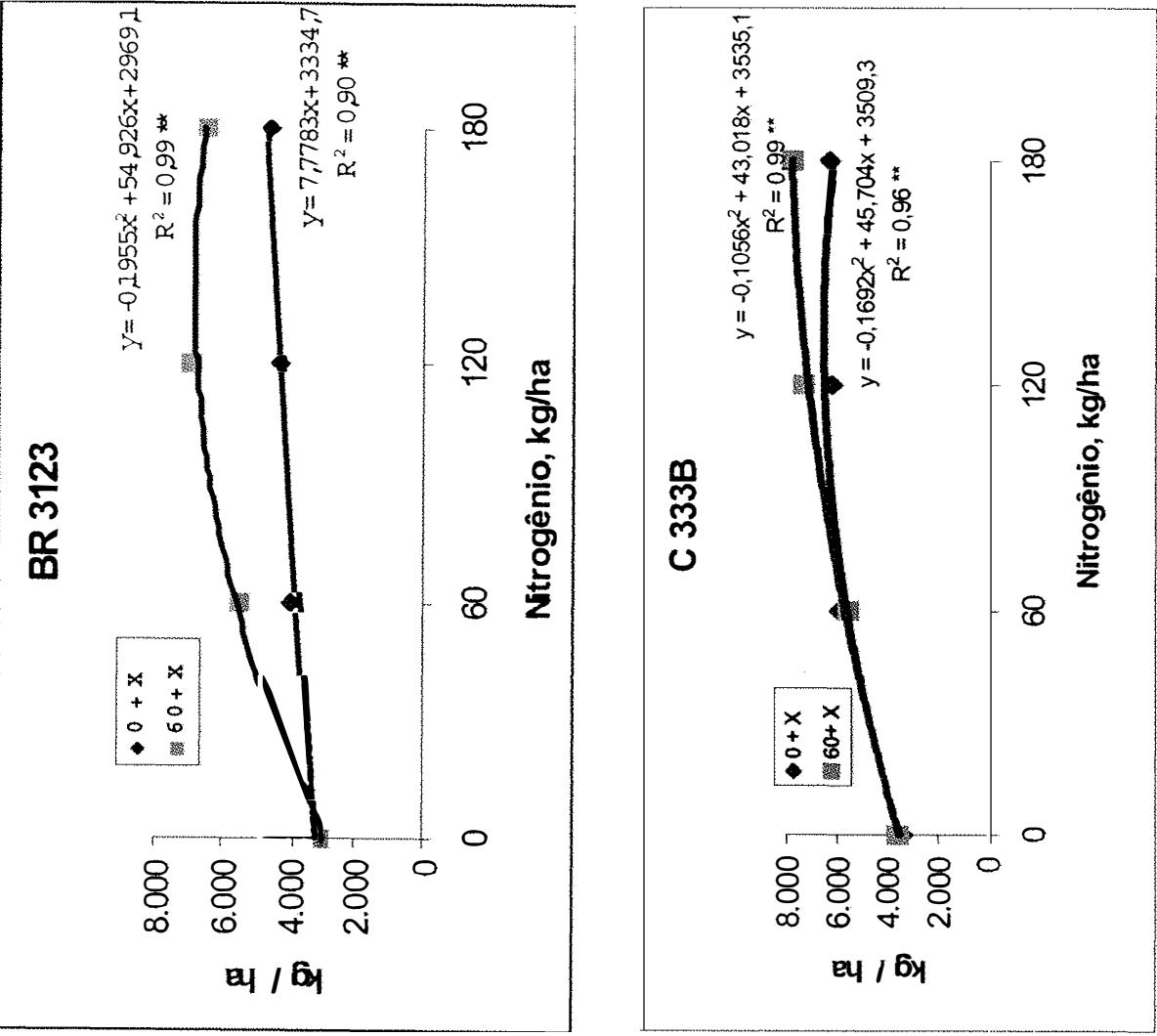

窟遭

है

을

T.

प

究

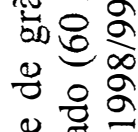

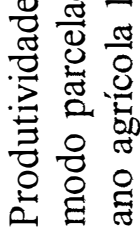

$\dot{\sim}$

营 

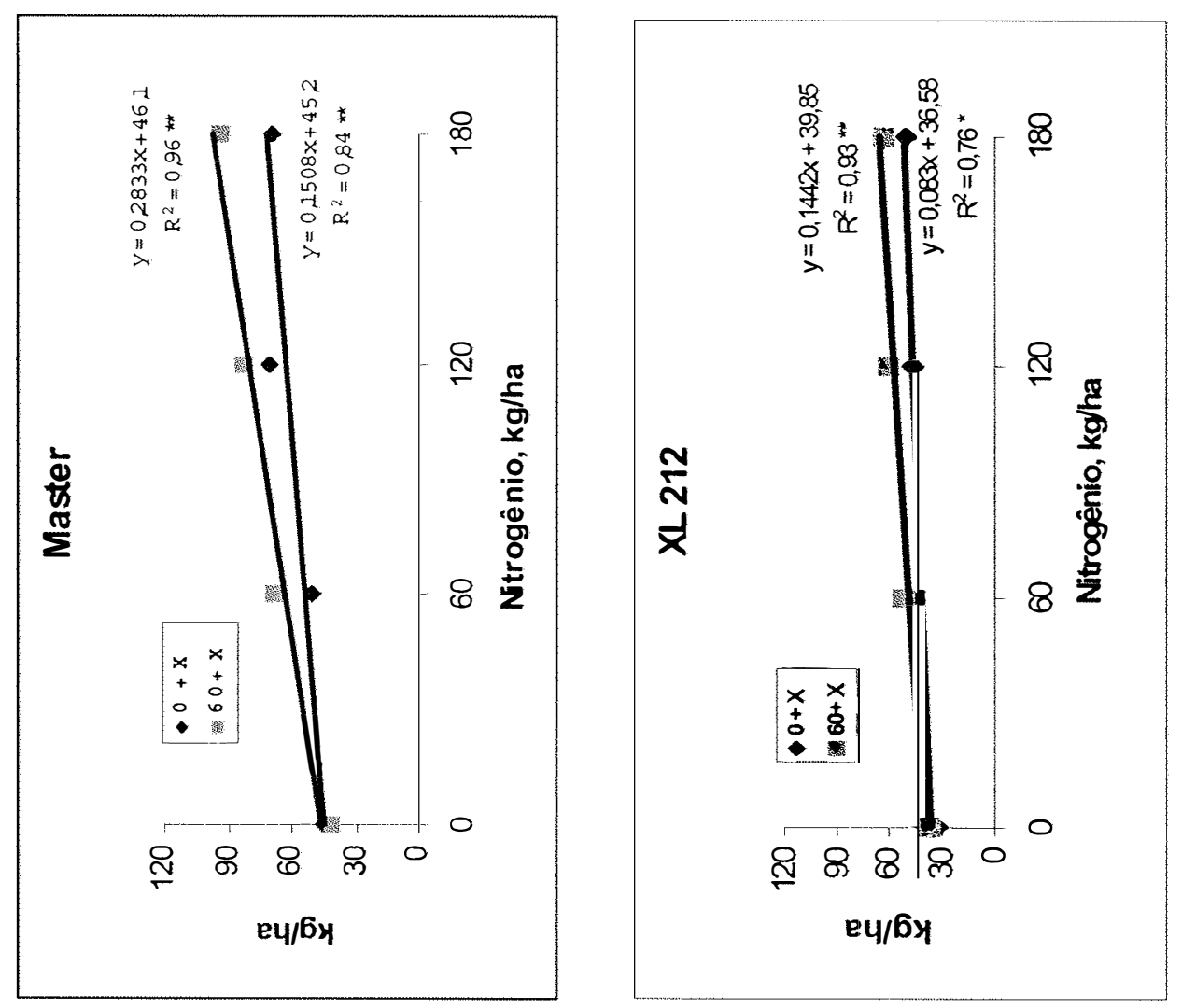

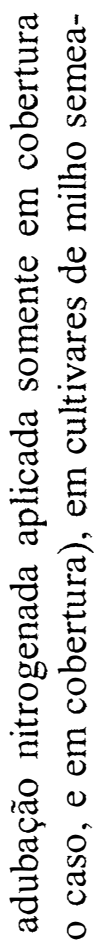

路
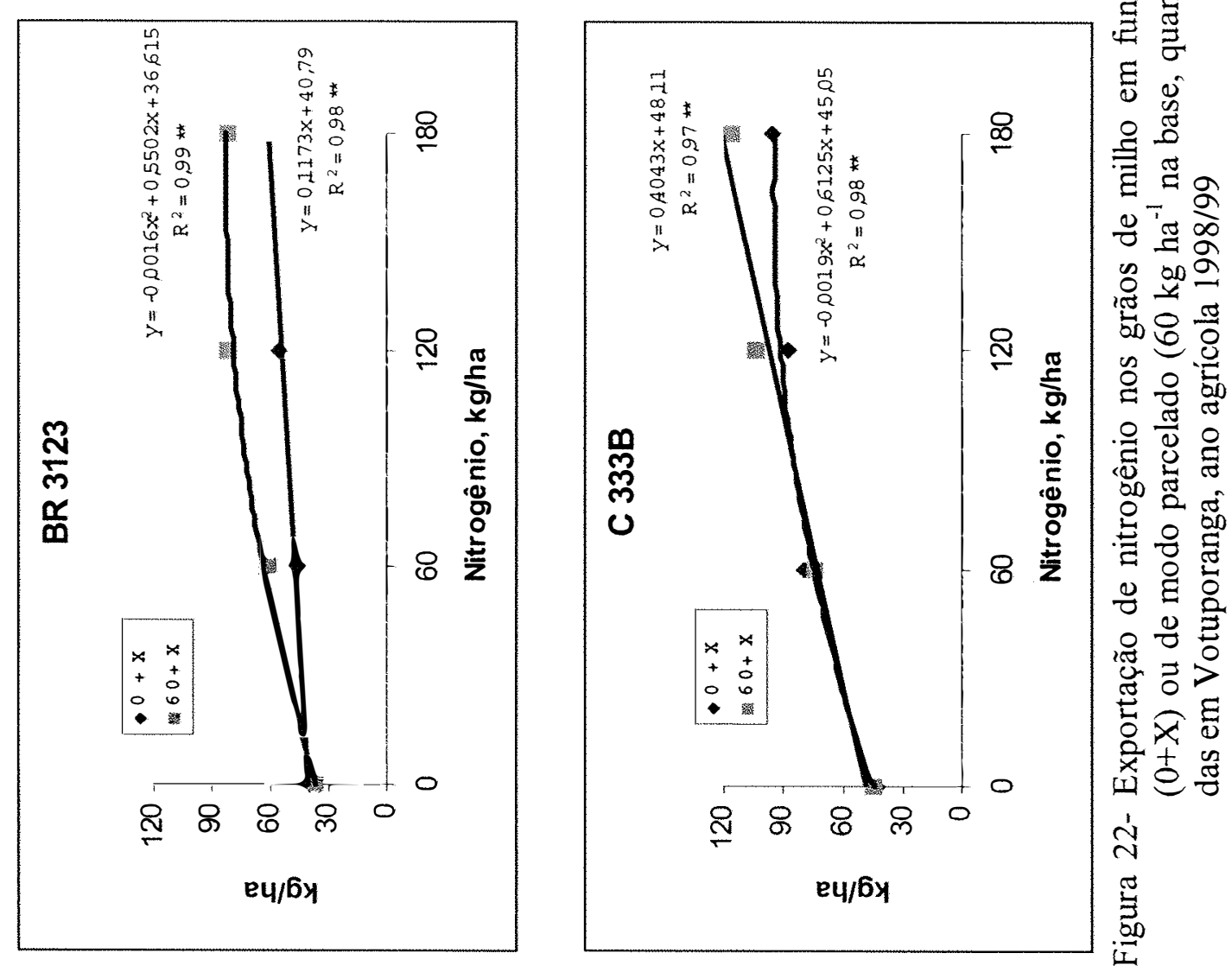


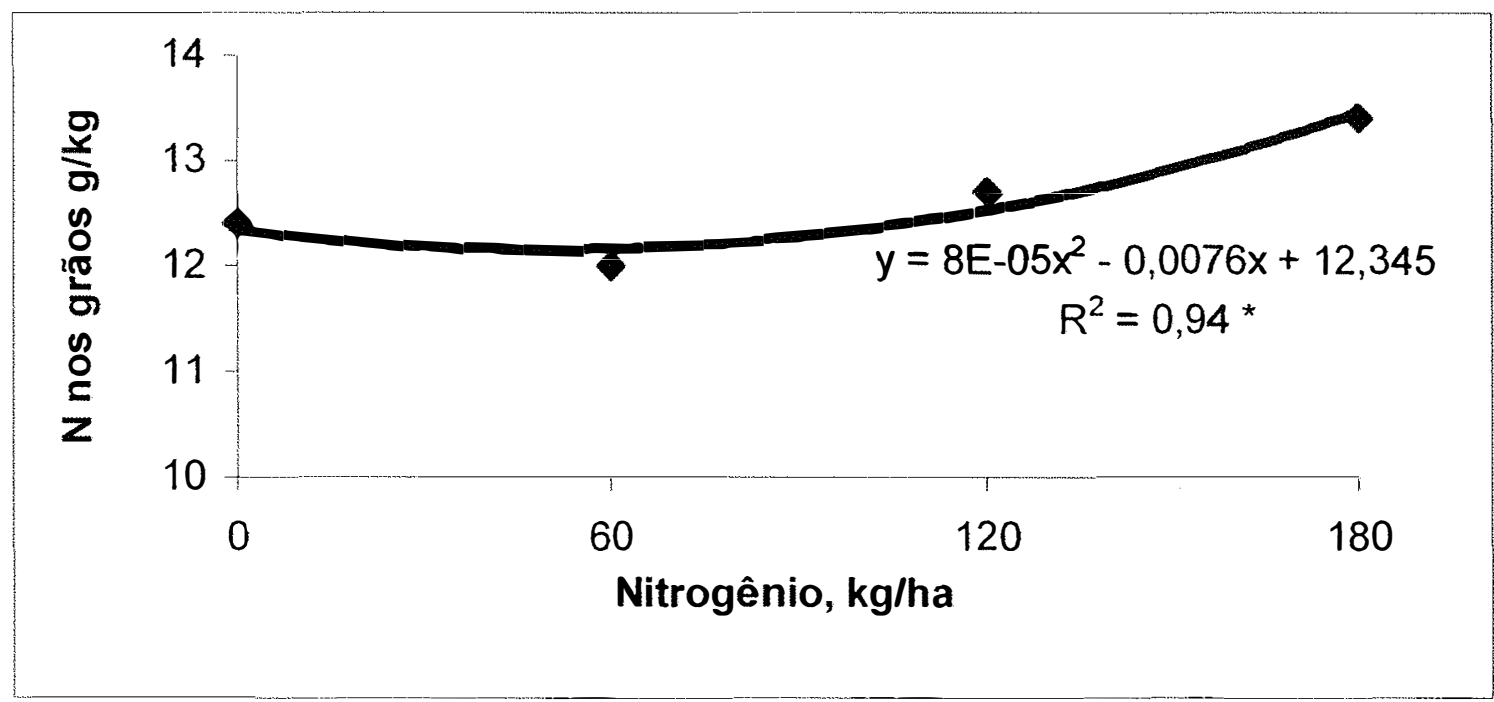

Figura 23- Conteúdo médio de nitrogênio em grãos de milho em função de doses do fertilizante nitrogenado, independentemente do modo de parcelamento, em Votuporanga, no ano agrícola 1998/99 (Média de quatro genótipos)

gência quanto ao suprimento de nitrogênio nos estádios iniciais de desenvolvimento. Porém, a diferenciação dos cultivares quanto ao nível de resposta é bastante complexdevido, entre outros fatores, à adaptação do germoplasma às condições edafoclimáticas regionais, que influencia a expressão do potencial produtivo, e à dificuldade de se predizer a disponibilidade de nitrogênio no solo durante os diversos estádios de desenvolvimento da cultura. 


\subsection{Suprojeto Partição}

As datas do florescimento e maturação fisiológica, esta última coincidente com a data de colheita de massa, indicam grande variabilidade do ciclo até o florescimento e a maturação fisiológica (Tabela 42). Em Palmital 99/00 a colheita de massa das cultivares precoces foi realizada depois da maturação dos grãos, devendo-se considerar com ressalvas o ciclo até a maturação fisiológica na interpretação dos resultados. Pela Tabela 42, depreende-se que o ciclo médio das plantas em Votuporanga 99/00 e Palmital 00/01 foi de 47 a 69 dias da emergência até o florescimento e de 86 a 117 dias da emergência até a maturação fisiológica, dependendo da cultivar.

Calculando-se a contribuição do subperíodo florescimento-maturação para o ciclo total da cultura, em graus dia, tem-se que este subperíodo correspondeu a $46 \%$, $45 \%, 47 \%, 49 \%$ e $55 \%$ da emergência até a maturação para as cultivares, P 32R21, BR 3123, BR 4157, AG 1051 e XL 212 respectivamente. Assim, as cultivares P32R21 e BR 3123, consideradas muito responsivas à adubação nitrogenada, tiveram o menor período relativo de desenvolvimento da espiga, enquanto a AG 1051, altamente produtiva mesmo na ausência de N, e a XL 212, pouco responsiva ao $\mathrm{N}$, tiveram os maiores períodos relativos.

As produtividades médias de grãos em Votuporanga 99/00, Palmital 99/00 e Palmital 00/01 foram iguais a 5.873, 3.881 e $7.409 \mathrm{~kg} \mathrm{ha}^{-1}$, respectivamente (Tabela 43). A baixa produtividade em Palmital 99/00 deve-se à ocorrência de veranico (ausência prolongada de chuvas) no período entre a emergência e o florescimento, o que também reduziu o porte das plantas. Em Palmital 1999/00, a cultivar superprecoce P 32R21 foi favorecida pelo florescimento antes de acentuar o déficit hídrico, e as mais tardias (XL 212 e Ag 1051), pelas chuvas imediatamente após o florescimento. Em Votuporanga 99/00 os tratamentos com ausência de $\mathrm{N} \mathrm{e} 60 \mathrm{~kg} \mathrm{ha}^{-1}$ de $\mathrm{N}$ produziram muito pouco em relação às doses $120 \mathrm{e} 180 \mathrm{~kg} \mathrm{ha}^{-1}$ em cobertura, contribuindo para a menor produtividade média dessa localidade em relação a Palmital 000/01. A ocorrência de elevada infestação do nematóide Pratylenchus sp também pode ter desfavorecido o desenvolvimento das plantas em Votuporanga 99/00. 


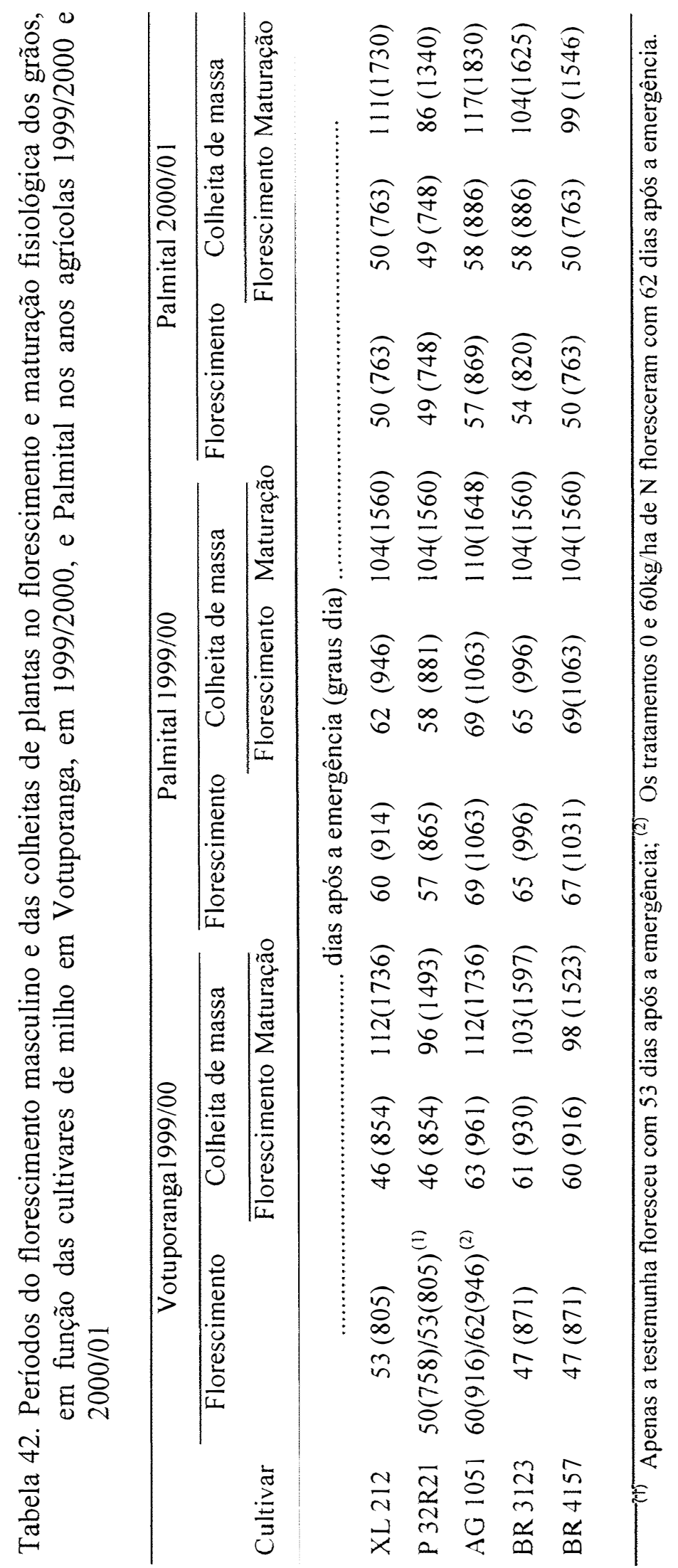


Tabela 43. Valores médios dos principais parâmetros de acúmulo e partição de matéria seca e nitrogênio nos três experimentos desenvolvidos no subprojeto Partição

\begin{tabular}{|c|c|c|c|c|}
\hline \multirow[b]{2}{*}{ Parâmetros avaliados } & & \multicolumn{3}{|c|}{ Experimento } \\
\hline & & $\begin{array}{c}\text { Votuporanga } \\
1999 / 00 \\
\end{array}$ & $\begin{array}{l}\text { Palmital } \\
1999 / 00 \\
\end{array}$ & $\begin{array}{l}\text { Palmital } \\
2000 / 01\end{array}$ \\
\hline Produtividade & $\mathrm{kg} \mathrm{ha}^{-1}$ & 5.873 & 3.881 & 7.409 \\
\hline Massa seca & Florescimento & 1351 & 1013 & 1228 \\
\hline g por 10 plantas & Maturação & 2711 & 1938 & 2990 \\
\hline Teor $\mathrm{N}-$ Folhas & Florescimento & 21,0 & 23,8 & $27 ; 2$ \\
\hline Verdes (secas), $\mathrm{g} \mathrm{kg}^{-1}$ & Maturação & $11,6(6,5)$ & $14,5(9,8)$ & $15,3(12,2)$ \\
\hline Teor N - Colmo & Florescimento & 6,6 & 8,4 & 9,5 \\
\hline $\mathrm{g} \mathrm{kg}^{-1}$ & Maturação & 5,0 & 4,8 & 5,7 \\
\hline Teor N - Planta & Florescimento & 12,4 & 14,2 & 17,9 \\
\hline $\mathrm{g} \mathrm{kg}^{-1}$ & Maturação & 8,7 & 9,7 & 11,3 \\
\hline Acúmulo $\mathrm{N}$ & Florescimento & 17,2 & 14,4 & 21,7 \\
\hline $\mathrm{g}$ por 10 plantas & Maturação & 23,8 & 19,0 & 33,8 \\
\hline $\mathrm{N}$ na fração folhas & Florescimento & 53,9 & 57,7 & 56,1 \\
\hline$\%$ do acumulados & Maturação & 16,5 & 19,1 & 15,1 \\
\hline $\mathrm{N}$ na fração colmos & Florescimento & 30,1 & 34,2 & 24,4 \\
\hline$\%$ do acumulado & Maturação & 18,9 & 17,4 & 15,8 \\
\hline $\mathrm{N}$ na fração espigas & Florescimento & 15,9 & 8,1 & 19,5 \\
\hline$\%$ do acumulado & Maturação & 64,6 & 63,5 & 69,1 \\
\hline $\begin{array}{l}\text { Massa folhas verdes } \\
\% \text { folhas total }\end{array}$ & Maturação & 57 & 85 & 65 \\
\hline Eficiência uso N planta & $\mathrm{kg}^{2} \mathrm{~g}^{-1}$ & 0,32 & 0,20 & 0,27 \\
\hline $\mathrm{N}$ na planta / $\mathrm{N}$ no adubo & $\mathrm{kg} \mathrm{kg}^{-1}$ & 1,5 & 1,2 & 2,0 \\
\hline Acúmulo relativo na planta & Matéria seca & 49,7 & 46,4 & 58,3 \\
\hline $\begin{array}{l}\text { Florescimento- Maturação } \\
\% \text { do total }\end{array}$ & Nitrogênio & 28,6 & 22,9 & 34,8 \\
\hline
\end{tabular}


A massa seca de plantas foi menor em Palmital 99/00. Em Votuporanga 99/00 e Palmital 00/01, os valores da massa seca de plantas foram muito próximos, especialmente no florescimento, embora a produtividade de grãos tenha sido menor em Votuporanga 99/00 do que em Palmital 00/01. Os menores teores médios de N na planta em Votuporanga 99/00, desde o estádio de florescimento até a maturação, especialmente nos tratamentos 0 e $60 \mathrm{~kg} \mathrm{ha}^{-1}$, contribuíram para as menores produtividades de grãos nesta localidade em comparação a Palmital 00/01.

Em todos os experimentos, os teores de $\mathrm{N}$ nas folhas, colmos e na planta toda reduziram do estádio de florescimento para o de maturação, sendo que a redução foi mais acentuada nas folhas do que nos colmos. A redução da contribuição do $\mathrm{N}$ acumulado nas folhas, em relação à planta como um todo, também foi muito mais acentuada do que nos colmos. Isso sugere que o principal reservatório de $\mathrm{N}$ para translocação para a espiga são as folhas.

Poder-se-ia relacionar a redução do teor de $\mathrm{N}$ nas folhas com o índice de secamento de folhas. Porém, em Palmital 99/00 a redução do acúmulo de N nas folhas foi acentuada e as plantas apresentavam $85 \%$ de folhas verdes na última colheita de massa. Essa percentagem de folhas verdes poderia ter sido ainda maior se o híbrido P32R21 não tivesse sido colhido um pouco depois da maturação físiológica e apresentado o menor índice de folhas verdes (76\%).

A eficiência do uso de $\mathrm{N}$ na planta, calculada pelo método de Siddiqi et al. (1981), foi menor em Palmital 99/00 do que nos demais locais e anos agrícolas. É provável que a deficiência acentuada de água no solo tenha favorecido o acúmulo de matéria no sistema radicular, em detrimento da parte aérea da planta, levando à menor eficiência em Palmital 99/00 do que nos outros experimentos. Em Palmital 99/00 houve também menor acúmulo de nitrogênio depois do florescimento; o maior acúmulo de matéria seca em comparação ao de nitrogênio no subperíodo florescimento-maturação, expresso como porcentagem do total acumulado até a maturação, foi mais acentuado em Palmital 99/00 do que nos outros dois experimentos.

Quanto maior foi a produtividade do experimento, maior a relação entre o $\mathrm{N}$ acumulado na planta e o aplicado como fertilizante, e maior o acúmulo relativo de 
matéria seca e nitrogênio no subperíodo florescimento-maturação. $O$ fato de os experimentos mais produtivos apresentarem maior relação entre o $\mathrm{N}$ acumulado na planta e o $\mathrm{N}$ do fertilizante indica que houve aumento do uso e exportação do $\mathrm{N}$ original do solo. Ou seja, quando o ambiente propicia maiores produtividades, a planta maximiza a produção e exportação de matéria seca por unidade de $\mathrm{N}$ absorvida e de $\mathrm{N}$ aplicada no fertilizante. O maior acúmulo de N no subperíodo florescimento-maturação, por sua vez, evidencia que o aumento do potencial produtivo é acompanhado pelo aumento da absorção de $\mathrm{N}$ depois do florescimento. Provavelmente, a obtenção de elevadas produtividades seja mais dependente da absorção de $\mathrm{N}$ depois do florescimento do que da translocação de $\mathrm{N}$ das folhas e colmos para a espiga.

\subsubsection{Efeito da cultivar}

Houve efeito de cultivar para quase todos os parâmetros de acúmulo e partição de massa seca de nitrogênio na planta nos estádios de florescimento e de maturação físiológica dos grãos, bem como para os parâmetros de eficiência de uso do $\mathrm{N}$ e caracterização de espigas (Tabelas 44 a 58).

Em Votuporanga 99/00 destacou-se a ausência de diferença entre as cultivares para a partição de massa seca (Tabela 45) e acúmulo de $\mathrm{N}$ na fração folha na maturação (Tabela 46). Nesse local houve maior massa de folha por planta em comparação com os outros experimentos. Em Palmital 99/00 também não houve efeito para esses parâmetros, porém, especificamente para folhas secas (Tabelas 50 e 51). No caso de Palmital 99/00, a baixa percentagem de folhas secas em relação à massa total de folhas contribuiu para essa ausência de diferença entre as cultivares.

Nos experimentos de Palmital, na maturação físiológica, não houve diferença entre as cultivares para acúmulo de $\mathrm{N}$ na planta inteira, em 99/00, e nos colmos, em 00/01. Em Palmital 99/00, a menor absorção relativa de $N$ depois do florescimento (apenas 22,9\% do acumulado até a maturação), subperíodo em que ocorre maior diferenciação no acúmulo de $\mathrm{N}$ entre as cultivares, e a limitação do porte das plantas por 


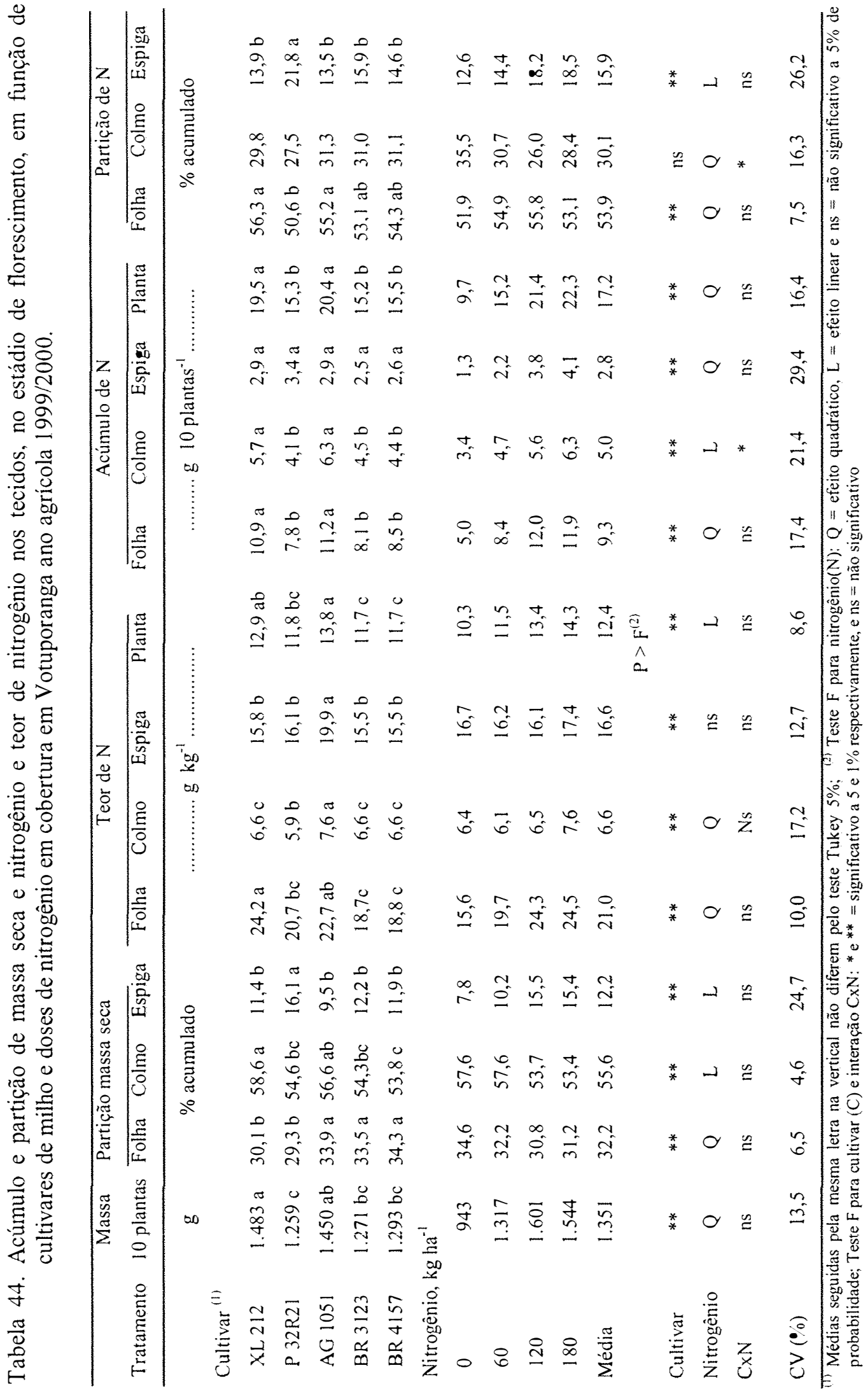




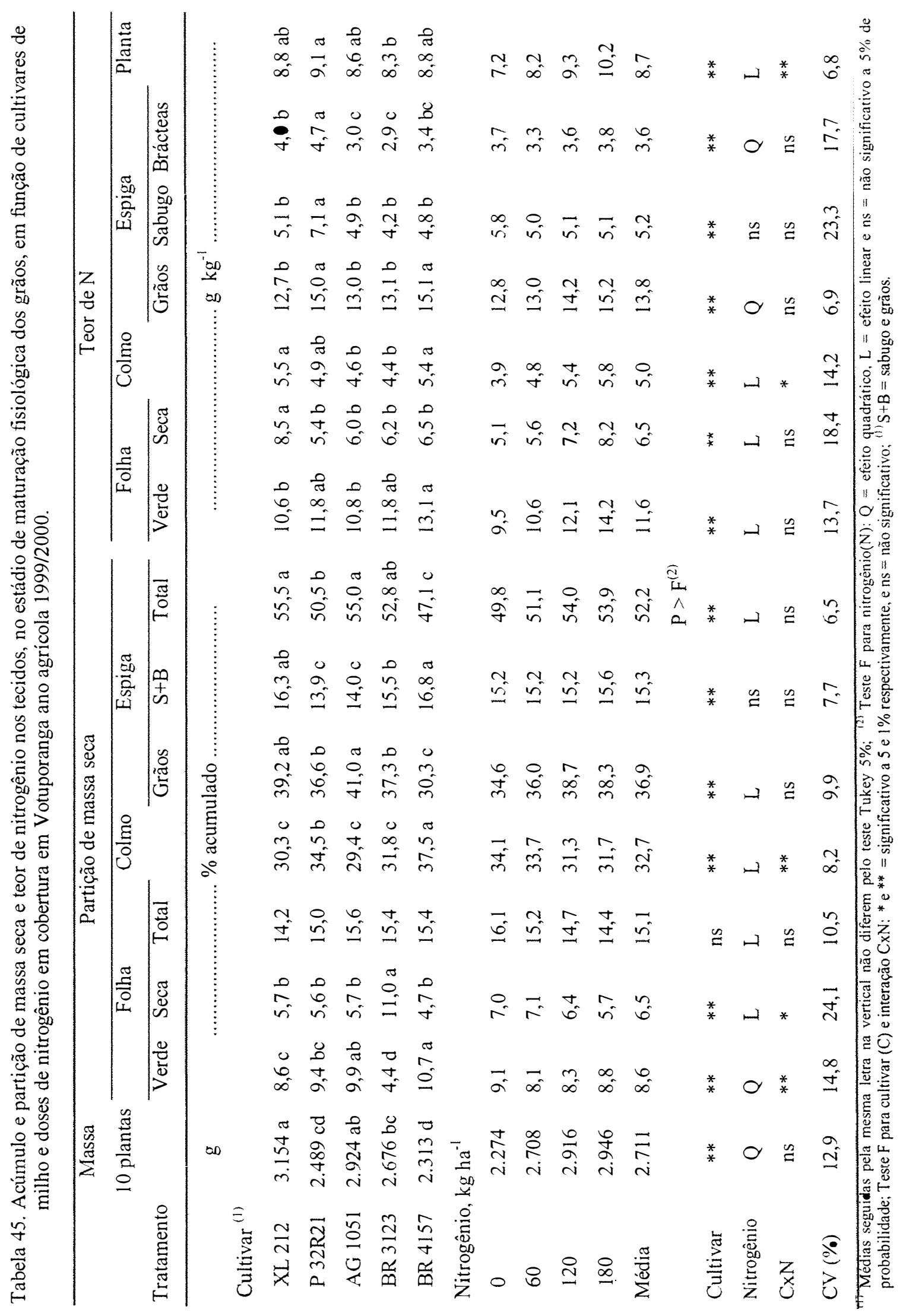




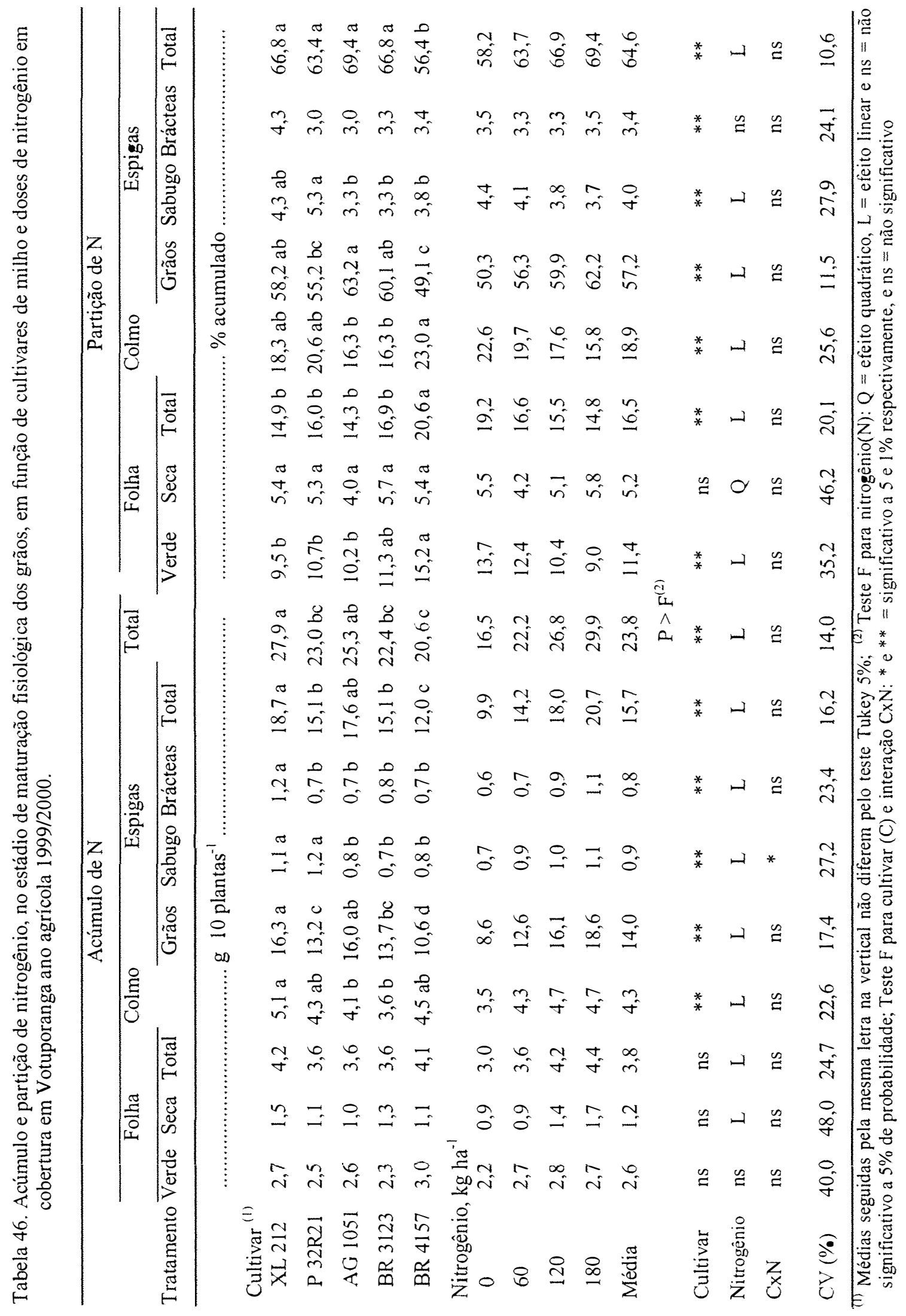




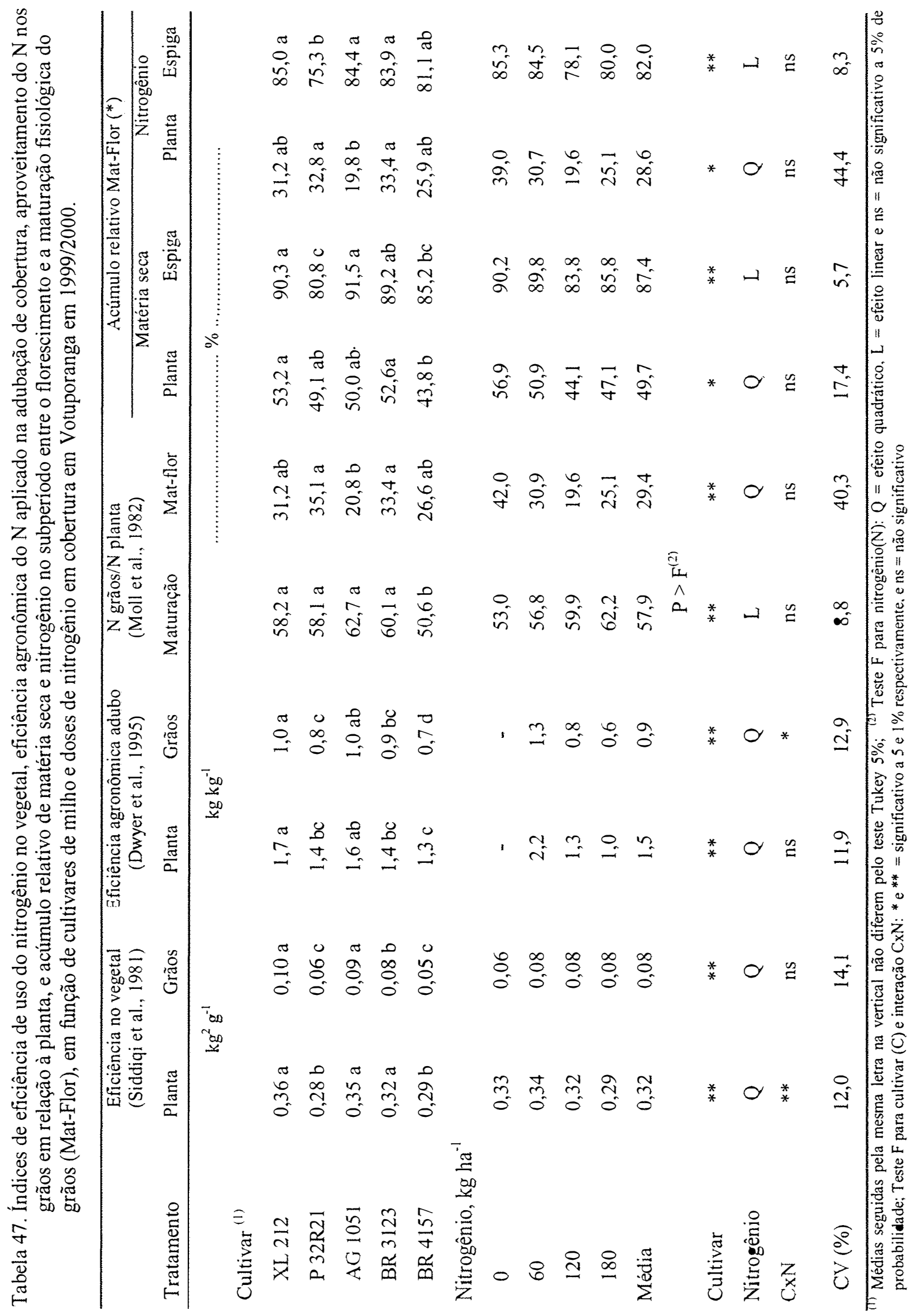




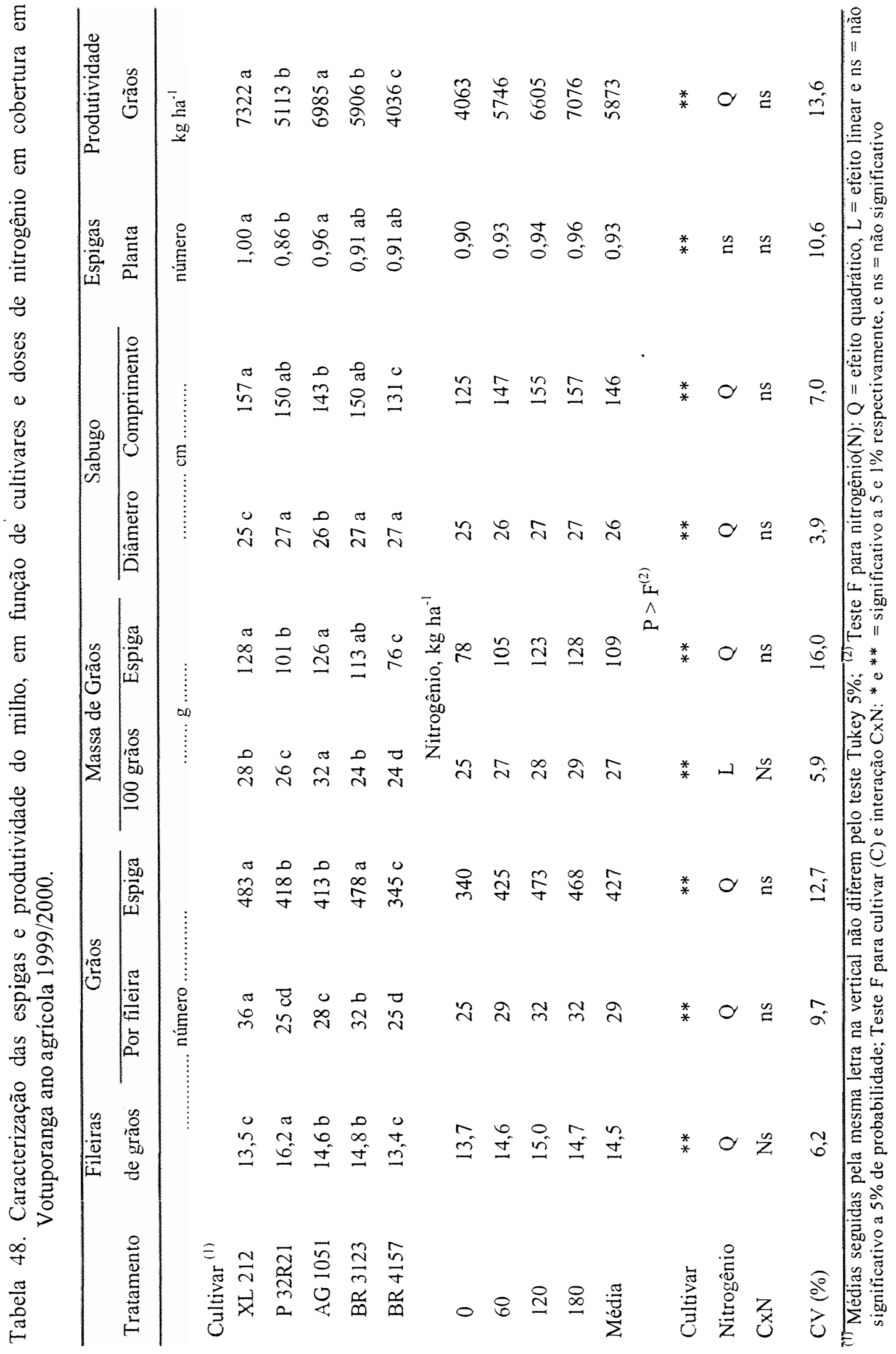




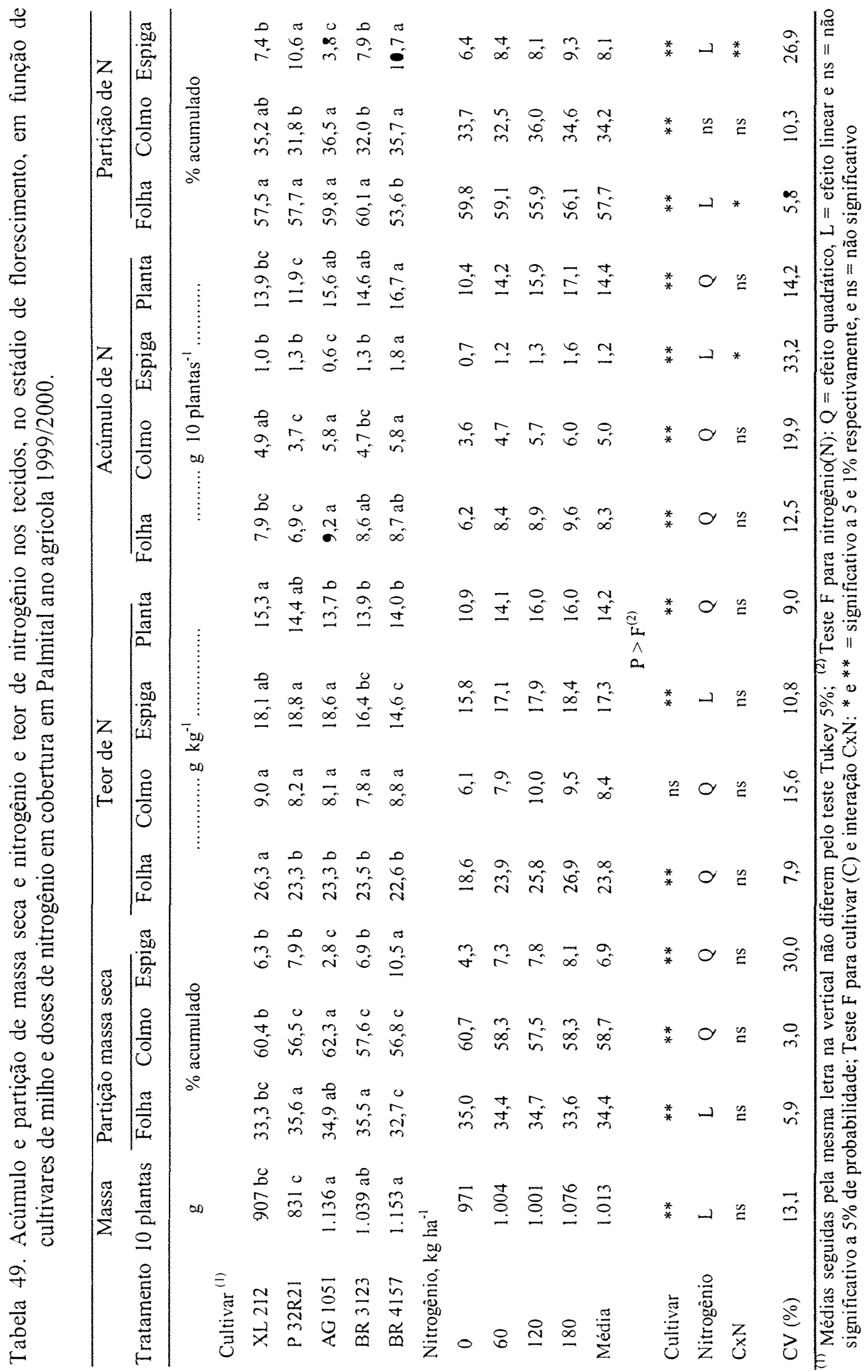




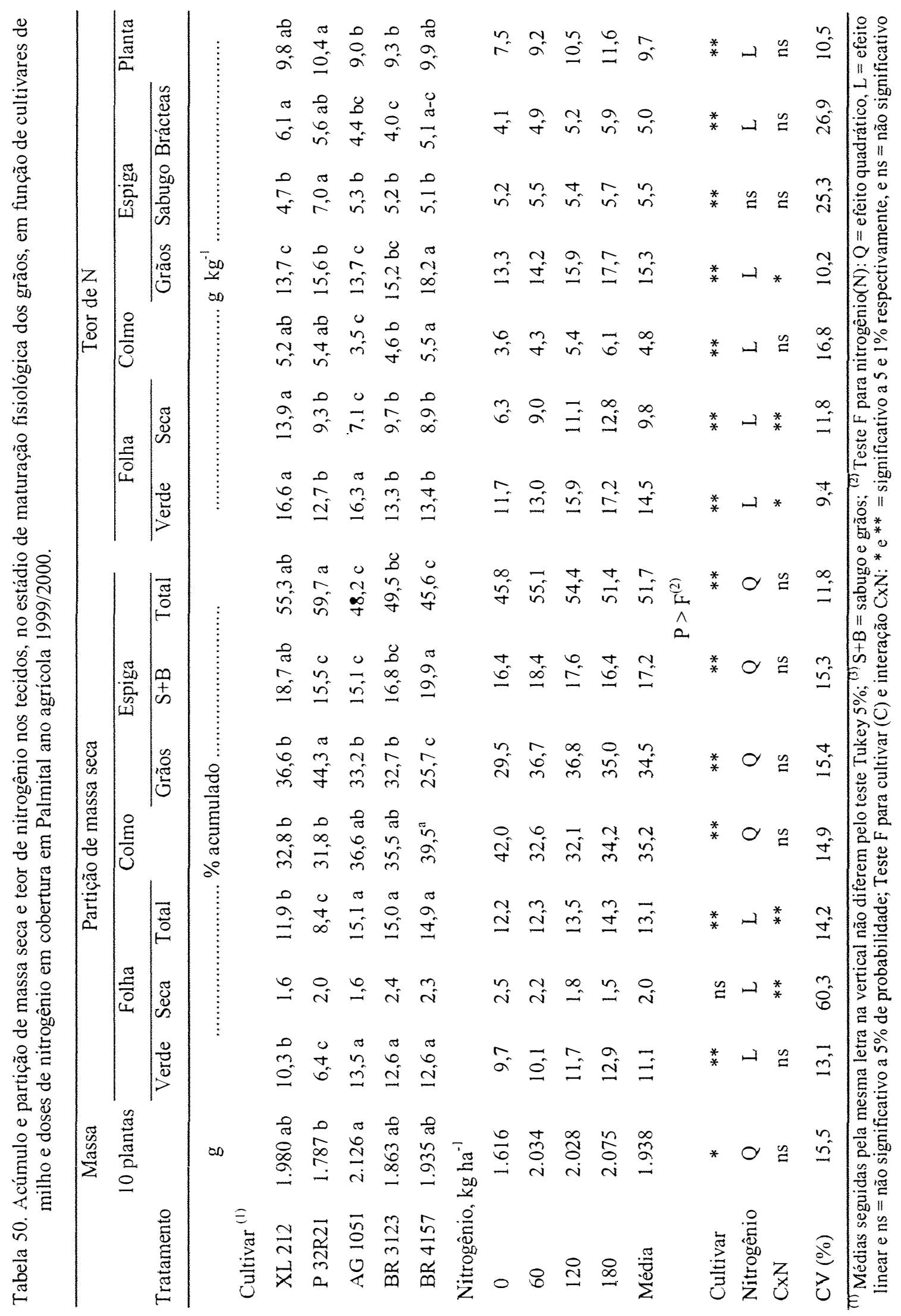




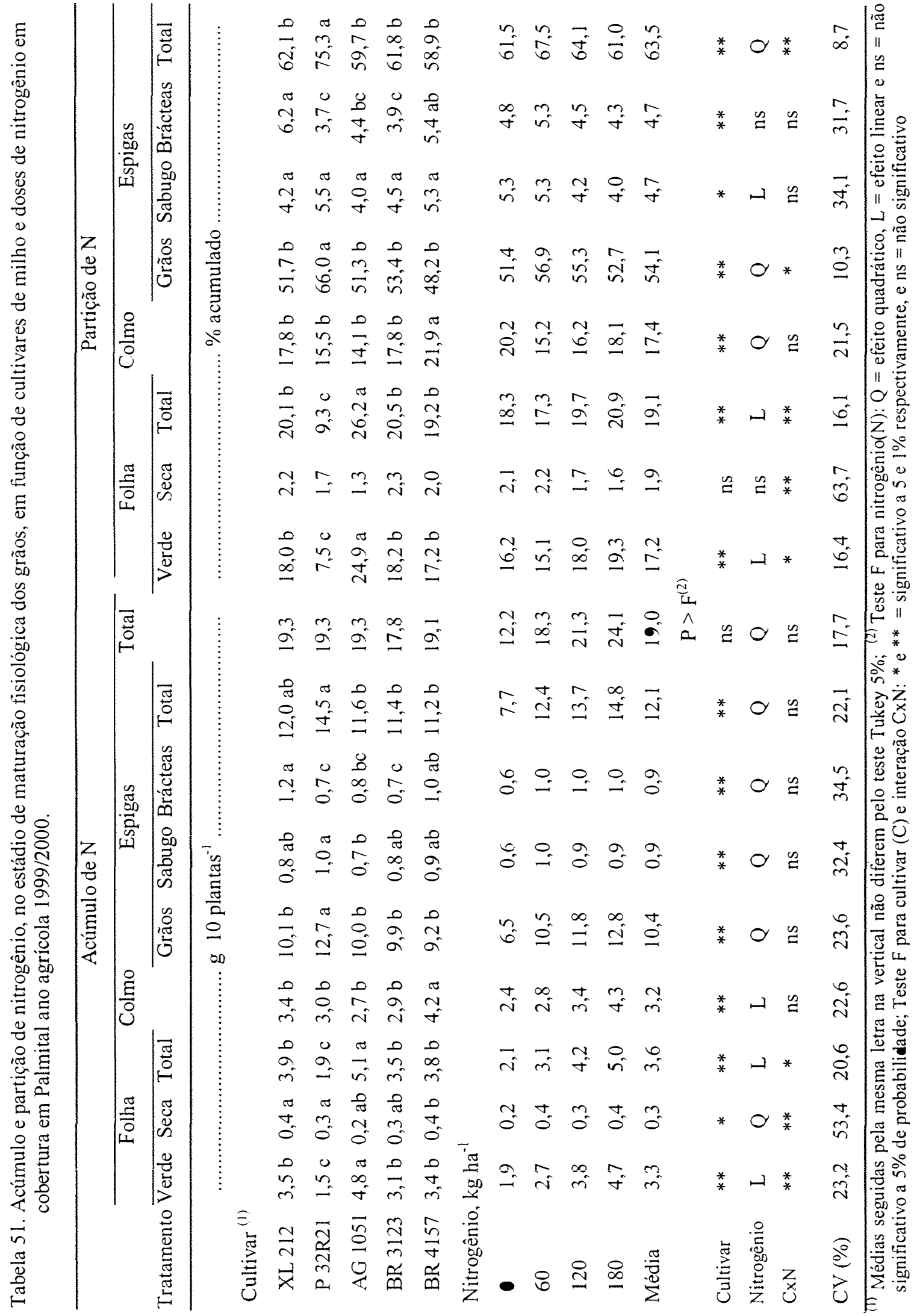




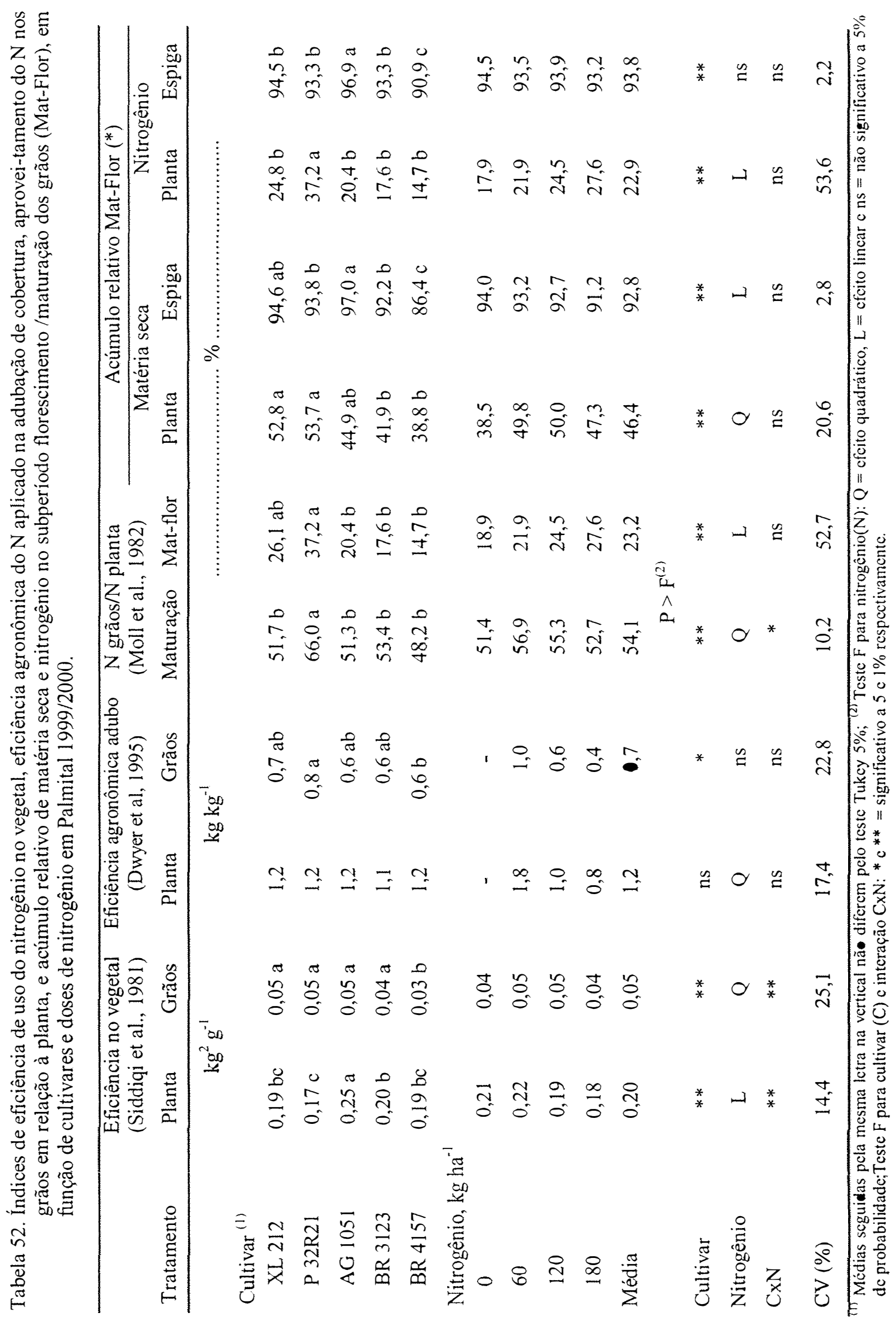




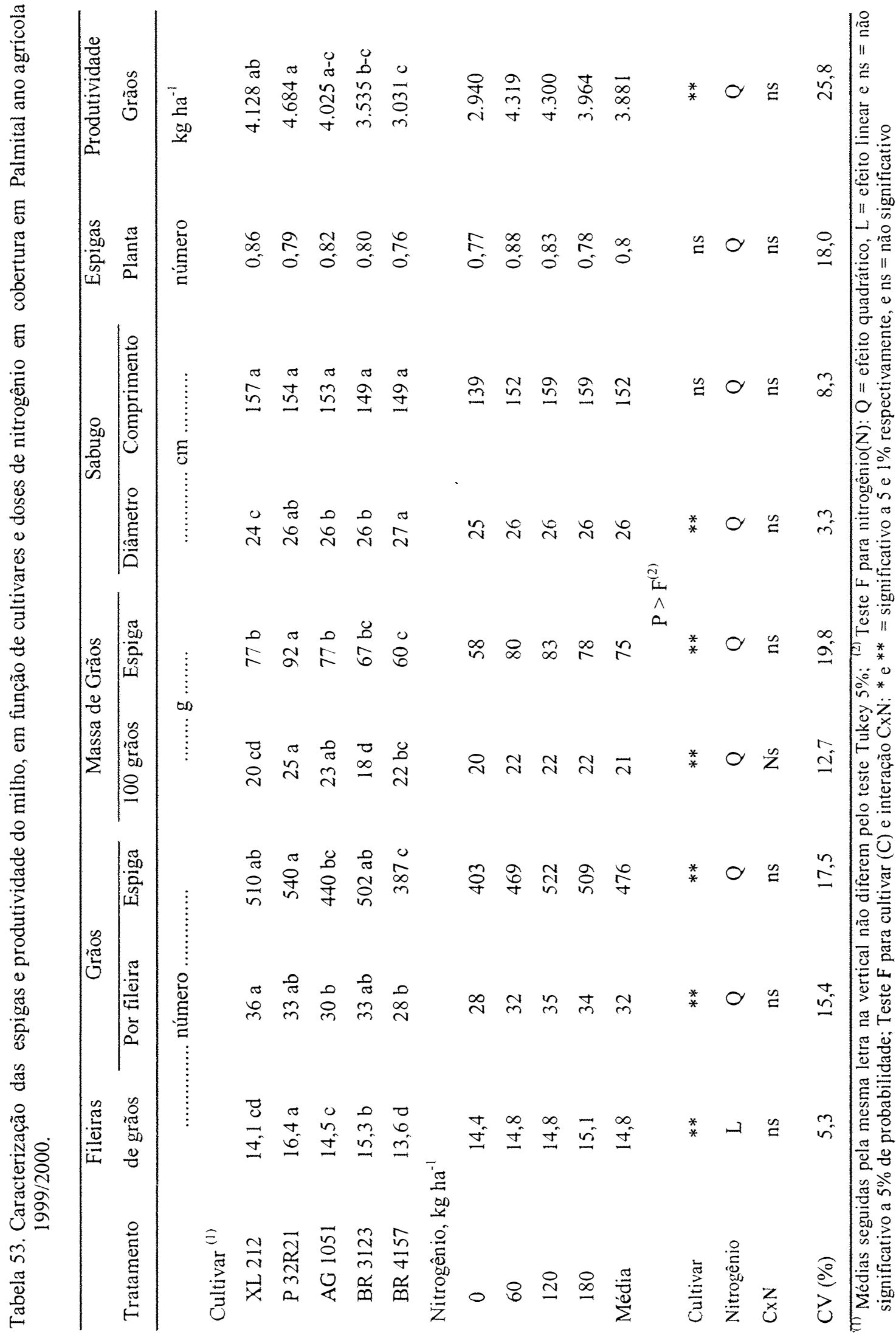




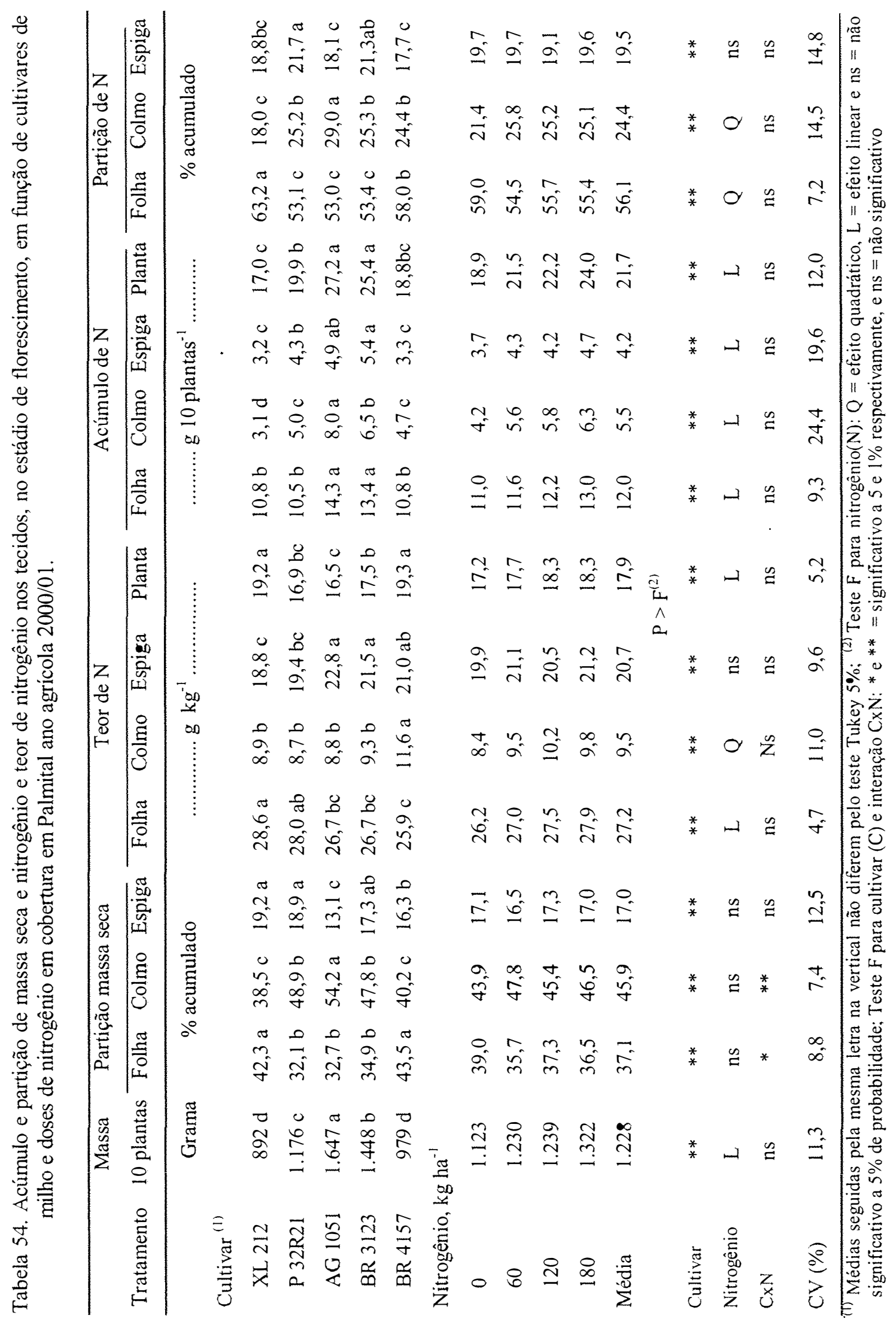




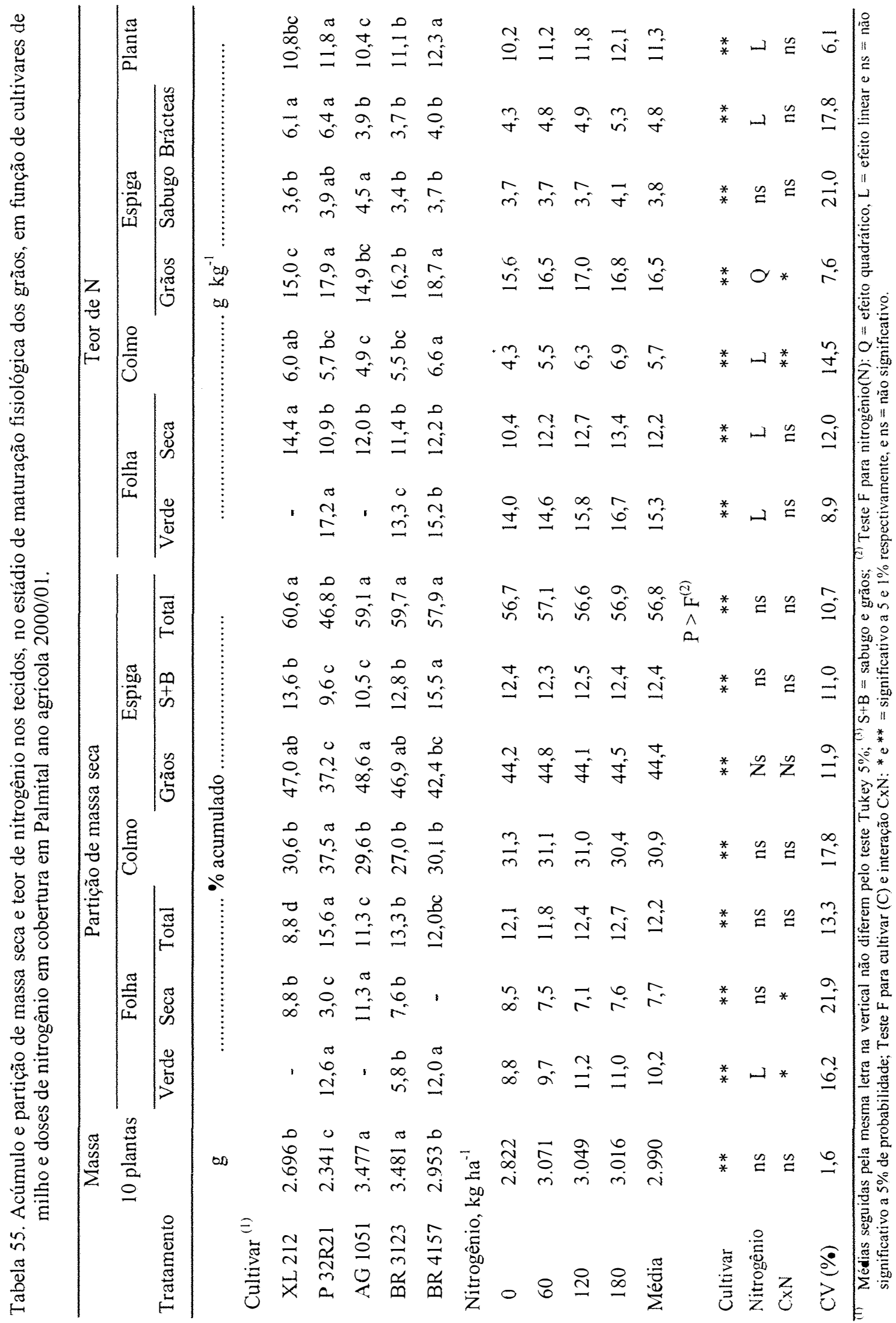




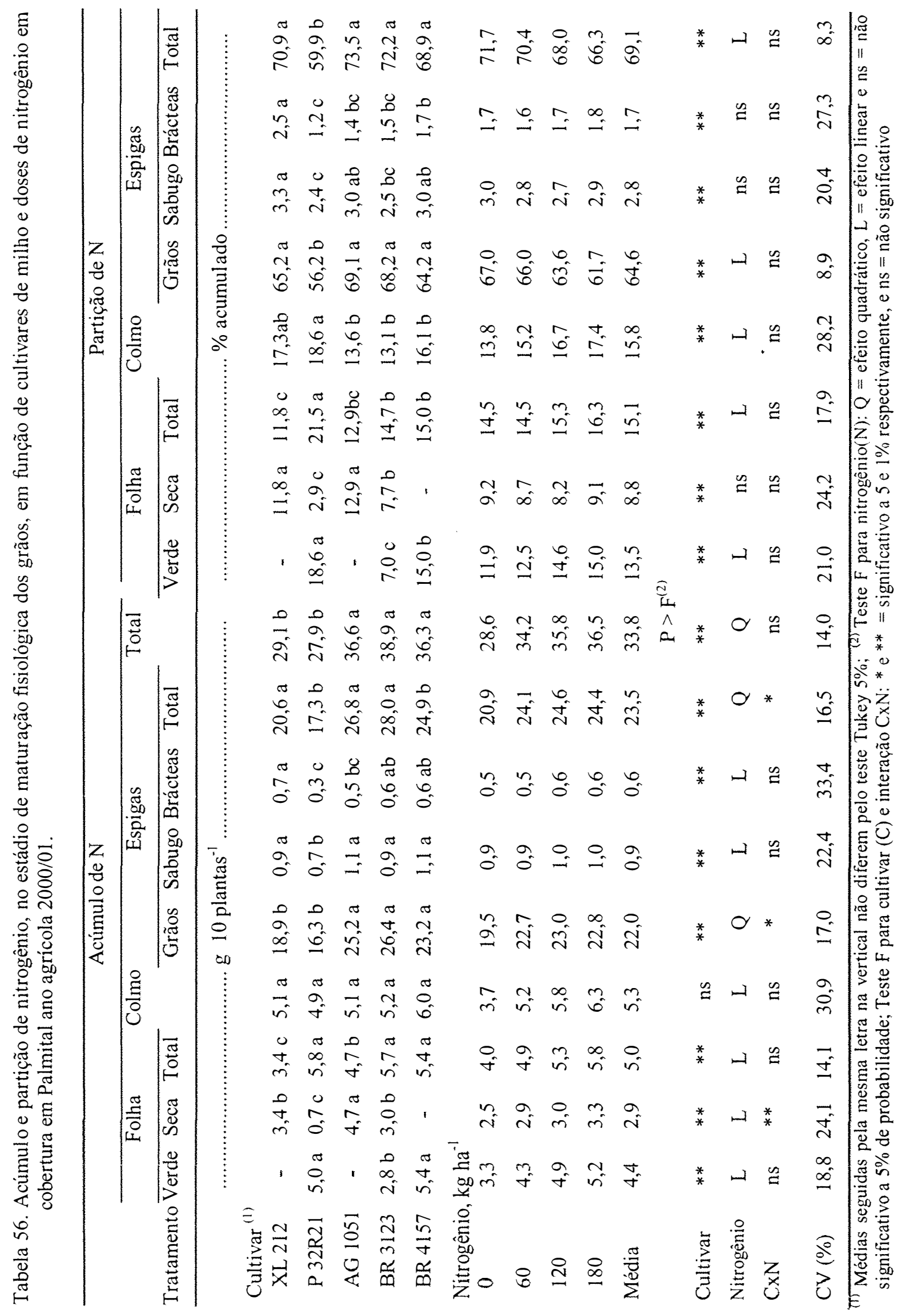




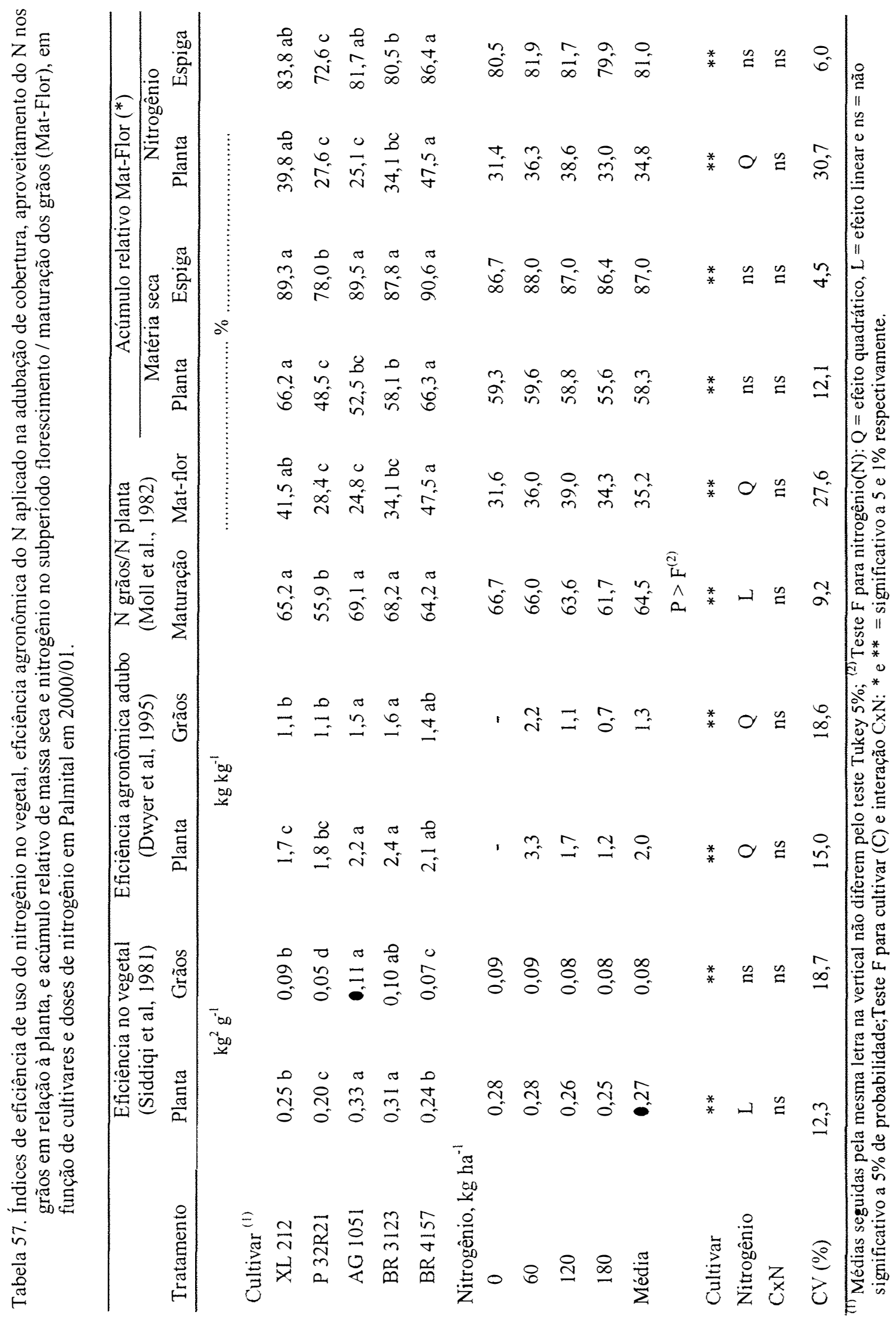




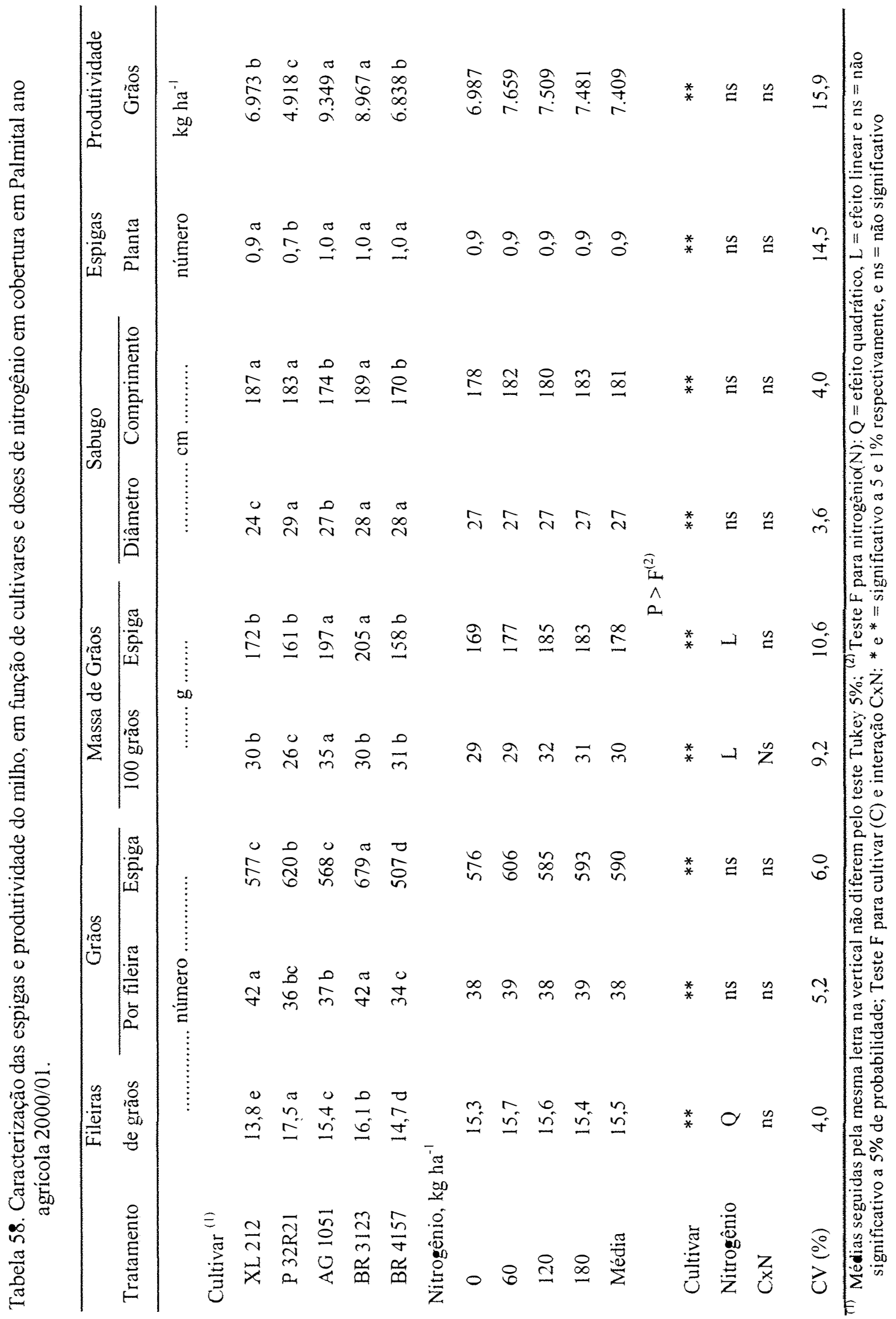


deficiência de água no solo, difícultaram a diferenciação das cultivares quanto ao acúmulo de $\mathrm{N}$ na planta inteira.

As cultivares P 32R21 e AG 1051 estiveram, respectivamente, sempre entre as menos e os mais produtivas em massa seca por planta no florescimento e maturação. Em Palmital 00/01, a massa seca por planta das cultivares XL 212 e BR 4157 foi inferior à da AG 1051 e BR 3123. Já em Votuporanga, algumas dessas cultivares apresentaram desempenho distinto; a XL 212 foi superior à BR 4157 em massa seca acumulada por planta.

De maneira geral, a AG 1051 e a BR 4157 apresentaram, respectivamente, o maior e menor valor relativo de massa seca acumulada na fração colmo no florescimento. Contraditoriamente, a BR 4157 mostrou um dos maiores acúmulos relativos (partição) de matéria seca na fração colmo na maturação. Ressalte-se que as datas de corte foram diferentes para cada cultivar, de acordo com a duração do seu ciclo.

Na colheita de massa no florescimento, as plantas já apresentavam espigas, o que pode ser explicado pelo sincronismo quase simultâneo da emissão do pendão (critério para determinar a época de corte) e da espiga. A AG 1051 foi a cultivar com menor proporção de massa seca na fração espiga no estádio de florescimento. Em Votuporanga 99/00, a P32R21 foi cortada com a maior quantidade de espigas no florescimento porque, devido à uniformidade de florescimento e sincronia de formação de espigas e pendão, colheita foi um pouco atrasada em relação às demais cultivares.

Na maturação, as cultivares com maior proporção de folhas secas foram as que apresentaram a menor partição de matéria seca nas folhas (verdes + secas), exceto em Votuporanga 99/00. Esse experimento foi o único em que o período imediatamente anterior à maturação dos grãos coincidiu com ausência de deficiência hídrica no solo. Em Palmital, as cultivares com menor partição de massa seca nas folhas foram a $\mathrm{P}$ 32R21 em 99/00 e a AG 1051 e XL 212 em 2000/01 (AG 1051 e XL 212 apresentaram maior proporção de folhas secas em Palmital 2000/01). Como já mencionado, de maneira geral a variedade BR 4157 apresentou um dos maiores acúmulos relativos de matéria seca na fração colmo na maturação. Porém, as diferenças entre as cultivares 
quanto à partição de matéria seca no colmo foram pouco consistentes entre os três experimentos.

A contribuição da espiga na matéria seca da planta esteve relacionada diretamente com a adaptação produtiva de cada cultivar no experimento e com a proporção de grãos na espiga. A BR 4157 apresentou sempre a menor massa relativa de grãos na espiga total (cálculos não apresentados). As maiores proporções de matéria seca na fração espiga foram obtidas nas cultivares XL 212 e AG 1051 em Votuporanga 99/00, e P 32R21 em Palmital 99/00, da mesma maneira que a produtividade de grãos. Já em Palmital 00/01, a P 32R21 mostrou a menor proporção de massa seca na fração espiga e produtividade de grãos. Logo, a P 32R21 destacou-se quanto à adaptação produtiva e ao acúmulo relativo de matéria seca na fração espiga, positivamente em Palmital 99/00 e negativamente em Palmital 00/01.

No florescimento, o teor de N nas folhas foi sempre maior na XL 212 em relação à BR 4157. Já a diferença entre as cultivares quanto ao teor de $\mathrm{N}$ nos colmos foi discreta e inconsistente entre os experimentos, devendo-se lembrar que estes teores foram muito mais baixos do que nas folhas.

As cultivares com maior partição de matéria seca na espiga no florescimento não tiveram maior teor de $\mathrm{N}$ neste órgão porque os grãos, que são a parte mais rica em $\mathrm{N}$ da espiga, ainda não haviam sido formados (fase de polinização). Por exemplo, a AG 1051 apresentou a menor partição de matéria seca e os maiores teores de $\mathrm{N}$ na fração espiga.

A XL 212 esteve sempre entre as cultivares com maior teor de $\mathrm{N}$ na planta inteira no florescimento, enquanto a BR 4157 apresentou a maior oscilação dos teores entre os locais em relação às demais cultivares. Ressalte-se que o teor de $\mathrm{N}$ na planta foi obtido através de cálculos, dividindo-se os acúmulos de $\mathrm{N}$ pelos de matéria seca na planta, ambos obtidos pela soma das frações. Na maturação, a XL 212 continuou apresentando maiores valores de $\mathrm{N}$ nas folhas, mas apenas nas classificadas como secas. Nesse estádio, os maiores teores de N no colmo foram encontrados na BR 4157 e XL 212 e os menores na AG 1051.

$\mathrm{Na}$ fração espiga, os teores de $\mathrm{N}$ nos grãos foram três a quatro vezes maiores do que no sabugo e brácteas. A P 32R21 e a BR 4157 apresentaram os maiores teores de N 
nos grãos, e a AG 1051 e a XL 212, os menores. De maneira geral, a P 32R21 apresentou também os maiores teores de $\mathrm{N}$ no sabugo e bráctea, evidenciando o grande requerimento de $\mathrm{N}$ para a formação das suas espigas. Os baixos valores de $\mathrm{N}$ nos grãos nas cultivares AG 1051 e XL 212 corroboram com o resultados do subprojeto genótipo x nitrogênio.

No florescimento, o híbrido P 32R21 esteve sempre entre as cultivares com menor acúmulo de $\mathrm{N}$ na planta total. Nesse estádio, o acúmulo e partição de $\mathrm{N}$ nas frações folha e colmo foram sempre maiores na $A G 1051$ do que na $P$ 32R21. A comparação das cultivares quanto ao acúmulo de $\mathrm{N}$ na fração espiga foi inconsistente entre os experimentos. A partição do acúmulo de $\mathrm{N}$, por sua vez, mostrou que a $\mathrm{P}$ 32R21 apresentou uma das maiores partições de $\mathrm{N}$ acumulado na espiga, especialmente quando comparada à AG 1051 em Plamital 99/00.

Na maturação, a P 32R21 esteve sempre entre as cultivares com maior teor de $\mathrm{N}$ na planta inteira, enquanto a XL 212 e a BR 4157 destacaram em dois dos três experimentos. Nesse estádio, nos experimentos em que existiram diferenças entre as cultivares quanto ao acúmulo de $\mathrm{N}$ na planta (Votuporanga 99/00 e Palmital 00/01), destacou-se positivamente a AG 1051, enquanto a XL 212 apresentou elevado acúmulo de $\mathrm{N}$ na planta em Votuporanga 99/00 e baixo acúmulo em Palmital 00/01.

Os maiores acúmulos de $\mathrm{N}$ nas espigas na maturação ocorreram nas cultivares XL 212 e AG 1051, com exceção de Palmital 99/00, em que a AG 1051 apresentou baixo acúmulo de $\mathrm{N}$ nas espigas, e a P 32R21, alto acúmulo. Quanto à partição do $\mathrm{N}$ acumulado na planta, a P 32R21 foi a cultivar com menor e maior acúmulo de $\mathrm{N}$ na fração espiga em Palmital 00/01 e Palmital 99/00 respectivamente. A BR 4157 apresentou menor partição de $\mathrm{N}$ nas espigas do que as demais cultivares em Votuporanga 99/00.

A proporção de $\mathrm{N}$ acumulado nos grãos em relação à espiga toda variou de $85 \%$ a 93\% nos experimentos, com diferenças discretas entre as cultivares. A variedade BR 4157 apresentou, concomitantemente, menor proporção de grãos na espiga e maior teor de $\mathrm{N}$ nos grãos, resultando valores relativos de $\mathrm{N}$ acumulado nos grãos semelhantes aos das demais cultivares. 
$\mathrm{Na}$ maturação, a partição de $\mathrm{N}$ acumulado nas folhas na $\mathrm{P}$ 32R21, em relação às demais cultivares avaliadas, foi menor em Palmital 99/00 e maior em Palmital 00/01. A BR 4157 destacou-se com elevados valores de partição de $\mathrm{N}$ nas folhas em Votuporanga 99/00.

Nos experimentos com maior produtividade de grãos, as cultivares tropicais AG 1051 e BR 3123 apresentaram a menor partição de $\mathrm{N}$ no colmo por ocasião da maturação.

Houve efeito de cultivar para todos os parâmetros de espiga e produtividade de grãos, exceto para o comprimento do sabugo e número de espigas por planta em Palmital 99/00 (Tabelas 48, 53 e 58).

A cultivar P 32R21 apresentou o maior número de fileiras por espiga, enquanto a XL 212 e a BR 4157 estiveram sempre entre as cultivares com menor número de fileiras por espiga. Houve associação entre os parâmetros número de filleiras e diâmetro do sabugo apenas para a XL 212: menos filleiras e menor diâmetro do sabugo. De maneira geral, o número de grãos por fileira e o comprimento do sabugo foram maiores na XL 212, do que na $A G 1051$ e na BR 4157. Em conseqüência do menor número de fileiras e de grãos por fileira, a BR 4157 apresentou o menor número de grãos por espiga. A BR 3123 esteve sempre entre as cultivares com maior número de grãos por espiga, e a AG 1051 entre as de maior massa de grãos por espiga.

Como a diferença entre as cultivares quanto ao número de espigas por planta foi pequena, os genótipos que se destacaram quanto à massa de grãos por espiga também sobressaíram-se quanto à produtividade de grãos por hectare, e vice-versa. Apenas em Palmital 00/01 a P 32R2 1 apresentou menor índice de espigas $(0,7)$ que as demais $(1,0)$.

AG 1051 e XL 212 apresentaram as maiores produtividades médias de grãos em Votuporanga 99/00, P 32R21, XL 212 e AG 1051 em Palmital 99/00 e AG 1051 e BR 3123 em Palmital 00/01. De maneira semelhante ao subprojeto Genótipos x Nitrogênio, a AG 1051, embora tenha sido responsiva ao nitrogênio, apresentou elevada produtividade relativa de grãos na testemunha. A variedade BR 4157 foi a menos produtiva em todos os locais, o que já era esperado por esta não ser um genótipo híbrido. 
A baixíssima produtividade da cultivar P 32R21 na testemunha em Votuporanga 99/00 contribuiu para baixar sua produtividade média nesse experimento.

As cultivares P 32R21 e XL 212 não são recomendadas para regiōes de clima com temperaturas muito elevadas, à semelhança de Votuporanga, e para semeaduras tardias, como em Palmital 00/01. Em Votuporanga 99/00, as temperaturas foram atipicamente amenas e favoráveis às cultivares P 32R21 e XL 212 (Anexo 1). Ressaltese que foram realizadas três pulverizações com fungicidas em cada local porque essas cultivares são suscetíveis às principais doenças que ocorrem em Palmital e Votuporanga. As pulverizações, juntamente com a baixa ocorrência de patógenos nas lavouras adjacentes, fizeram com que a incidência de doenças nos experimentos fosse desprezível.

Houve efeito de cultivares para todos os índices de acúmulo e de eficiência de uso de nitrogênio nas plantas (Tabelas 47, 52 e 57), exceto para a relação entre o acúmulo de $\mathrm{N}$ na planta e o $\mathrm{N}$ aplicado no adubo (eficiência agronômica do fertilizante) em Palmital 99/00, onde a produtividade foi muito baixa.

De maneira geral, a AG 1051 e a BR 3123 apresentaram as maiores produções de massa na planta por unidade de N no tecido, a XL 212 e a BR 4157 mostraram valores intermediários e a P 32R21 apresentou os menos valores. Esse resultado é coerente com os já mencionados sobre os maiores teores de $\mathrm{N}$ na planta na cultivar $\mathrm{P} 32 \mathrm{R} 21$ e as menores na AG 1051 e BR 3123. Já a produção de matéria seca por unidade de $\mathrm{N}$ nos grãos foi maior na AG 1051 e XL 212, as quais tiveram os menores teores de $\mathrm{N}$ nos grãos.

A comparação das cultivares quanto à relação entre o $\mathrm{N}$ acumulado na planta ou no grão e o $\mathrm{N}$ aplicado no adubo foi semelhante à comparação das cultivares quanto à produtividade de grãos: quanto maior a produtividade da cultivar, maior a eficiência agronômica do fertilizante.

Os resultados da relação entre o $\mathrm{N}$ acumulado nos grãos e o acumulado na planta no estádio de maturação fisiológica dos grãos mostram poucas diferenças entre as cultivares. A P 32R21 diferiu das demais em Palmital, apresentando maiores valores de exportação de $\mathrm{N}$ quando a sua produtividade no experimento foi elevada (Palmital 
99/00) e menores exportações quando a produtividade foi baixa (Palmital 00/01). Em Votuporanga 99/00, a BR 4157 mostrou o menor valor de acúmulo de $\mathrm{N}$ nos grãos em relação ao $\mathrm{N}$ acumulado na planta devido à sua baixa produtividade de grãos.

De maneira geral, a AG 1051 apresentou o menor acúmulo de $\mathrm{N}$ na espiga em relação ao $\mathrm{N}$ acumulado na planta no subperíodo florescimento-maturação, devido ao baixo teor de $\mathrm{N}$ nos grãos.

A XL 212 foi uma das cultivares que mostrou maior acúmulo relativo de matéria seca na planta no subperíodo florescimento-maturação, expresso como porcentagem do acumulado até a maturação fisiológica dos grãos. $\mathrm{O}$ acúmulo relativo de matéria seca na espiga no subperíodo florescimento-maturação foi maior na AG 1051 em comparação à BR 4157 e P 32R21 em Palmital 99/00 e à BR 4157 em Votuporanga 99/00. Em Palmital 00/01, onde a época de semeadura foi tardia, a P 32R21 apresentou menor acúmulo relativo de matéria seca nesse subperíodo do que as demais cultivares, e a BR 4157 acumulou mais. Com exceção de Palmital 00/01, a BR 4157 esteve entre as cultivares que menos acumularam matéria seca na planta nesse subperíodo.

A diferenciação das cultivares pelo acúmulo relativo de $\mathrm{N}$ na planta no subperído florescimento-maturação, expressa como porcentagem do acumulado até a maturação fisiológica dos grãos, não correspondeu exatamente à diferenciação pelo acúmulo relativo de matéria seca na planta no referido subperíodo. A AG 1051 e a XL 212 acumularam mais $\mathrm{N}$ depois do florescimento, expresso como porcentagem do total, do que a P 32R21 e BR 4157 em Votuporanga 99/00, e a XL 212 e P32R21 foram as que apresentaram o maior acúmulo de relativo em Palmital 99/00, mas não diferiram da $A G$ 1051. Já em Palmital 00/01, sobressaíram-se a AG 1051 e a XL 212 com os maiores acúmulos relativos de $\mathrm{N}$ depois do florescimento.

A inferência "quanto maior a produtividade do experimento maior o acúmulo relativo de matéria seca e nitrogênio nas plantas depois do florescimento", não pode ser interpretada em sentido inverso. Ou seja, as cultivares com maior acúmulo de matéria seca e/ou nitrogênio na planta depois do florescimento não foram sempre as mais produtivas. Por exemplo, as cultivares XL 212 e AG 1051, as quais estiveram sempre 
entre as de maior acúmulo relativo de matéria seca e nitrogênio nesse subperíodo, produziram menos grãos do que a AG 1051 e BR 3123 em Palmital 00/01.

\subsubsection{Efeito do nitrogênio}

Houve efeito do nitrogênio para a maioria dos parâmetros acúmulo e partição de massa seca e nitrogênio na planta nos estádios de florescimento e maturação, eficiência de uso de $\mathrm{N}$ e caracterização de espigas (Quadros 44 a 58, Anexos 2 e 7 a 11).

No florescimento, nos dois experimentos em Palmital, o teor de $\mathrm{N}$ na espiga não diferiu entre as doses do fertilizante devido à inexistência de grãos desenvolvidos. Em Palmital 00/01 não houve efeito do nitrogênio para os parâmetros massa por planta e partição de massa seca nas duas épocas de corte, exceto para partição de colmo no florescimento e partição de folha verde na maturação. Provavelmente, os teores relativamente elevados de $\mathrm{N}$ inorgânico no solo até $40 \mathrm{~cm}$ de profundidade permitiram o seu adequado suprimento para as plantas em todos os tratamentos.

Nos três experimentos, o teor de $\mathrm{N}$ no sabugo não variou com as doses de nitrogênio, com a ressalva de que houve elevados coeficientes de variação. As partículas de sabugo moídas são muito desuniformes em tamanho e a amostra utilizada na determinação de $\mathrm{N}$ é muito pequena $(0,2 \mathrm{~g})$, limitando a representatividade da amostra. A partição de $\mathrm{N}$ nas brácteas também não foi influenciada pelo nitrogênio.

$\mathrm{O}$ efeito do nitrogênio para a partição de $\mathrm{N}$ nas folhas secas foi significativo apenas em Votuporanga 99/00, cujas plantas, conforme já comentando, não apresentaram período de estresse hídrico imediatamente antes da maturação fisiológica dos grãos.

Com a exceção dos casos já mencionados, e da partição de matéria seca e $\mathrm{N}$ nas folhas secas, a aplicação de nitrogênio em cobertura aumentou o teor de $\mathrm{N}$ e o acúmulo de matéria seca e nitrogênio em todas as frações da planta. Para alguns parâmetros os valores obtidos na dose $180 \mathrm{~kg} \mathrm{ha}^{-1}$ foram semelhantes ou inferiores aos obtidos com $120 \mathrm{~kg} \mathrm{ha}^{-1}$, sugerindo que a maior dose foi excessiva. 
A proporção de folhas secas foi maior na testemunha e sofreu redução com a adubação nitrogenada, exceto em Palmital 00/01. Com isso, a partição de matéria seca e nitrogênio nas folhas secas diminuiu com as doses de $\mathrm{N}$.

A partição de massa seca na espiga aumentou, e a partição de massa seca no colmo diminuiu com as doses de nitrogênio nas duas épocas de avaliação, exceto em Palmital 00/01, onde o efeito do nitrogênio não foi significativo. Houve efeito para o parâmetro partição de sabugo + brácteas apenas em Palmital 99/00, com aumento e posterior queda relativa dos valores dessa fração com as doses de $\mathrm{N}$.

No florescimento, a partição de $\mathrm{N}$ na folha e colmo seguiu a mesma tendência da partição de massa seca apenas em Votuporanga 99/00, ou seja, aumentou nas folhas e diminuiu nos colmos com as doses de N. Em Palmital 00/01 ocorreu o inverso: a partição de $\mathrm{N}$ na folha diminuiu e a do colmo aumentou com a aplicação de $\mathrm{N}$; a diminuição do N na fração folha também foi observada em Palmital 99/00.

$\mathrm{Na}$ maturação, a partição de $\mathrm{N}$ na fração colmo diminuiu e a partição de $\mathrm{N}$ na fração espiga aumentou com a aplicação de N em Votuporanga 99/00 e Palmital 99/00. Já em Palmital 00/01, onde o solo era mais rico em nitrogênio inorgânico, a partição de $\mathrm{N}$ nas frações colmo e folha aumentou e na fração espiga diminuiu com o nitrogênio, sugerindo excesso de crescimento vegetativo.

Resumindo, nos experimentos em houve resposta da produtividade de grãos ao nitrogênio (Votuporanga 99/00 e Palmital 99/00), a partição de matéria seca e nitrogênio no colmo diminuiu com as doses de nitrogênio no estádio de maturação dos grãos. Nesses experimentos, a proporção de $\mathrm{N}$ na fração sabugo diminuiu concomitantemente com o aumento do $\mathrm{N}$ na fração grãos. Assim, com deficiência de $\mathrm{N}$, pouco $\mathrm{N}$ é direcionado para as espigas ou, proporcionalmente, permanece mais $\mathrm{N}$ nos colmos no final do ciclo da cultura, sugerindo que existe limitação da produtividade devido ao fator dreno. O acúmulo de $\mathrm{N}$ na fração folha, por sua vez, foi aumentado em Palmital nos dois anos agrícolas e diminuído em Votuporanga 99/00 com a aplicação de nitrogênio. Em Votuporanga 99/00, a adubação nitrogenada aumentou o $\mathrm{N}$ acumulado na fração grãos em detrimento de colmos e folhas. 
Entre os parâmetros nos quais houve interação entre cultivares e doses de nitrogênio ( $\mathrm{N}$ x $\mathrm{C})$, destacaram-se a partição de matéria seca (maturação) e de nitrogênio (florescimento) acumulados no colmo e a relação entre o acúmulo de $\mathrm{N}$ nos grãos / N na planta em Votuporanga 99/00, e o teor de N nos grãos em Palmital 00/01 (Quadros 59 a 66). Em Palmital 99/00 sobressaiu-se a interação N x C para a partição de $\mathrm{N}$ nas folhas e nos grãos ou espigas nas duas épocas de avaliação.

A XL 212 e AG 1051, de ciclo mais longo e relativamente adaptadas à ausência de adubação nitrogenada, foram as únicas em que a partição de matéria seca e de nitrogênio no colmo não foi alterada em Votuporanga 1999/00 (Tabelas 59 e 60). No florescimento, as cultivares BR 3123 e BR 4157 sofreram redução na produção de matéria seca e nitrogênio na fração colmo com a aplicação de $\mathrm{N}$, em função do aumento do acúmulo relativo nas frações espiga e folha com a adubação nitrogenada. A AG 1051 foi a única cultivar em que os teores de $\mathrm{N}$ no colmo na maturação não aumentaram com as doses desse nutriente. A relação $\mathrm{N}$ acumulado nos grãos/ $\mathrm{N}$ acumulado na planta, por sua vez, permaneceu constante apenas nas cultivares temperadas XL 212 e P 32R21, aumentando com as doses de nitrogênio nas demais (Tabela 61).

Em Palmital 99/00, as cultivares que reduziram a partição de $\mathrm{N}$ nas folhas com as doses de N (XL 212, AG 1051 e BR 3123) foram as que, ao mesmo tempo, não alteraram a partição de $\mathrm{N}$ nas folhas no estádio de maturação (Tabelas 62 e 64). Já a P 32R21 e a BR 4157 aumentaram a partição de $N$ na fração folha com a adubação nitrogenada. Nesse experimento, as cultivares P 32R21 e BR 3123, mais responsivas ao nitrogênio, foram as únicas que apresentaram aumento da partição de matéria seca ou nitrogênio na fração espiga com as doses de nitrogênio (Tabelas 59 a 66).

Em Palmital 00/01, na maturação, o teor de $\mathrm{N}$ nos grãos aumentou apenas nas cultivares XL 212 e AG 1051 (Tabela 66). Essas cultivares mostraram o maior comprimento relativo do ciclo entre o florescimento e a maturação, apresentaram praticamente todas as folhas secas no estádio de maturação e, consequentemente, menor partição de $\mathrm{N}$ nas folhas em relação às demais cultivares.

A adubação nitrogenada de cobertura propiciou aumentos de produtividade que corresponderam a 74\% e 47\% em Votuporanga 99/00 e Palmital 99/00 respectivamente. 
Tabela 59. Partição de $\mathrm{N}$ acumulado na fração colmo no estádio de florescimento em função de doses de nitrogênio e cultivar em Votuporanga 1999/2000

\begin{tabular}{|c|c|c|c|c|c|c|}
\hline \multirow[b]{2}{*}{ Cultivar ${ }^{(1)}$} & \multicolumn{4}{|c|}{ Nitrogênio, $\mathrm{kg} \mathrm{ha}^{-1}$} & \multirow[b]{2}{*}{ Média } & \multirow{2}{*}{$\begin{array}{c}\mathrm{P}>\mathrm{F}^{(2)} \\
\text { nitrogênio }\end{array}$} \\
\hline & 0 & 60 & 120 & 180 & & \\
\hline \multicolumn{7}{|c|}{ 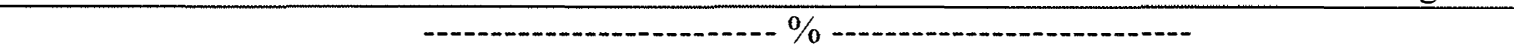 } \\
\hline XL 212 & $31 \mathrm{~b}$ & $29 \mathrm{a}$ & 28 & $31 \mathrm{a}$ & $30 \mathrm{a}$ & ns \\
\hline P 32R21 & $31 \mathrm{ab}$ & $26 \mathrm{a}$ & $27 a$ & $26 \mathrm{a}$ & $28 \mathrm{a}$ & $\mathrm{ns}$ \\
\hline$A G 1051$ & $34 \mathrm{ab}$ & $34 \mathrm{a}$ & 26 & $31 \mathrm{a}$ & $31 \mathrm{a}$ & ns \\
\hline BR 3123 & $42 \mathrm{a}$ & $29 \mathrm{a}$ & 23 & $30 \mathrm{a}$ & $31 \mathrm{a}$ & $\mathrm{Q}$ \\
\hline BR 4157 & $40 \mathrm{ab}$ & $35 \mathrm{a}$ & 26 & $24 \mathrm{a}$ & $31 \mathrm{a}$ & $\mathrm{L}$ \\
\hline Média & 35 & 31 & 26 & 28 & 30 & \\
\hline $\mathrm{P}>\mathrm{F}$ cultivar & ns & $* *$ & $* *$ & $* *$ & $* *$ & $\mathrm{Q}$ \\
\hline
\end{tabular}

"1) Médias seguidas pela mesma letra na vertical não diferem pelo teste Tukey $5 \%$, Teste $F:{ }^{*} \mathrm{e}^{*}=$ significativo a 5 e $1 \%$ respectivamente: ${ }^{(2)}$ Teste $\mathrm{F}: \mathrm{Q}=$ efeito quadrático, $\mathrm{L}=$ efeito linear e $\mathrm{ns}=$ não significativo a $5 \%$ de probabilidade; ${ }^{(2)}$

Tabela 60. Partição de massa seca na fração colmo no estádio de maturação em função de doses de nitrogênio e cultivar em Votuporanga 1999/2000

\begin{tabular}{|c|c|c|c|c|c|c|}
\hline \multirow[b]{2}{*}{ Cultivar ${ }^{(1)}$} & \multicolumn{4}{|c|}{ Nitrogênio, $\mathrm{kg} \mathrm{ha}^{-1}$} & \multirow[b]{2}{*}{ Média } & \multirow{2}{*}{$\begin{array}{c}\mathrm{P}>\mathrm{F}^{(2)} \\
\text { nitrogênio }\end{array}$} \\
\hline & 0 & 60 & 120 & 180 & & \\
\hline \multicolumn{7}{|c|}{ - } \\
\hline XL 212 & $30 \mathrm{bc}$ & $31 \mathrm{~b}$ & $30 \mathrm{~b}$ & $30 \mathrm{~b}$ & $30 \mathrm{c}$ & ns \\
\hline P 32R21 & $36 \mathrm{ab}$ & $33 \mathrm{~b}$ & $32 a b$ & $37 \mathrm{a}$ & $35 \mathrm{~b}$ & Q \\
\hline AG 1051 & $29 \mathrm{c}$ & $32 \mathrm{~b}$ & $29 \mathrm{~b}$ & $28 \mathrm{~b}$ & $29 \mathrm{c}$ & ns \\
\hline BR 3123 & $34 \mathrm{bc}$ & $33 \mathrm{~b}$ & $30 \mathrm{~b}$ & $30 \mathrm{~b}$ & $32 \mathrm{bc}$ & $\mathrm{L}$ \\
\hline BR 4157 & $41 \mathrm{a}$ & $40 \mathrm{a}$ & $37 \mathrm{a}$ & $33 \mathrm{ab}$ & $38 \mathrm{a}$ & $\mathrm{L}$ \\
\hline Média & 34 & 34 & 31 & 32 & 33 & \\
\hline $\mathrm{P}>\mathrm{F}$ cultivar & $* *$ & $* *$ & $* *$ & $* *$ & $* *$ & $\mathrm{~L}$ \\
\hline
\end{tabular}

Tabela 61. Relação entre o acúmulo de $\mathrm{N}$ nos grãos e o acúmulo de $\mathrm{N}$ na planta (Moll et al., 1982) no estádio de maturação fisiológica dos grãos em função de doses de nitrogênio e cultivar em Votuporanga 1999/2000

\begin{tabular}{lcccccc}
\hline & \multicolumn{4}{c}{ Nitrogênio, $\mathrm{kg} \mathrm{ha}^{-1}$} & \multicolumn{2}{c}{$\begin{array}{c}\mathrm{P}>\mathrm{F}^{(2)} \\
\text { Cultivar }\end{array}$} \\
\cline { 2 - 4 } & 0 & 60 & 120 & 180 & Média & nitrogênio \\
\hline XL 212 & $58 \mathrm{a}$ & $60 \mathrm{a}$ & $57 \mathrm{ab}$ & $59 \mathrm{a}$ & $58 \mathrm{a}$ & $\mathrm{ns}$ \\
P 32R21 & $55 \mathrm{a}$ & $57 \mathrm{ab}$ & $60 \mathrm{ab}$ & $59 \mathrm{a}$ & $58 \mathrm{a}$ & $\mathrm{ns}$ \\
AG 1051 & $58 \mathrm{a}$ & $61 \mathrm{a}$ & $62 \mathrm{ab}$ & $69 \mathrm{a}$ & $63 \mathrm{a}$ & $\mathrm{L}$ \\
BR 3123 & $53 \mathrm{a}$ & $58 \mathrm{ab}$ & $66 \mathrm{a}$ & $64 \mathrm{a}$ & $60 \mathrm{a}$ & $\mathrm{L}$ \\
BR 4157 & $41 \mathrm{~b}$ & $48 \mathrm{~b}$ & $54 \mathrm{~b}$ & $60 \mathrm{a}$ & $51 \mathrm{~b}$ & $\mathrm{~L}$ \\
Média & 53 & 57 & 60 & 62 & 58 & $* *$ \\
P>F cultivar & $* *$ & $* *$ & ns & $* *$ & $* *$ & L. \\
\hline
\end{tabular}

${ }^{\pi}$ Médias seguidas pela mesma letra na vertical não diferem pelo teste Tukey $5 \%$, Teste $\mathrm{F}^{*} \mathrm{e}^{*}=$ significativo a 5 e $1 \%$ respectivamente; ${ }^{(2)}$ Teste $\mathrm{F}: \mathrm{Q}=$ efeito quadrático, $\mathrm{L}=$ efeito linear e ns = não significativo a $5 \%$ de probabilidade; ${ }^{(2)}$ 
Tabela 62. Partição de N na fração folha no estádio de florescimento em função de doses de nitrogênio e cultivar em Palmital 1999/2000

\begin{tabular}{|c|c|c|c|c|c|c|}
\hline \multirow[b]{2}{*}{ Cultivar ${ }^{(1)}$} & \multicolumn{4}{|c|}{ Nitrogênio, $\mathrm{kg} \mathrm{ha}^{-1}$} & \multirow[b]{2}{*}{ Média } & \multirow{2}{*}{$\begin{array}{c}\mathrm{P}>\mathrm{F}^{(2)} \\
\text { nitrogênio }\end{array}$} \\
\hline & 0 & 60 & 120 & 180 & & \\
\hline \multicolumn{7}{|c|}{ - 0} \\
\hline XL 212 & $61 \mathrm{ab}$ & $60 \mathrm{ab}$ & $53 \mathrm{a}$ & $56 \mathrm{a}$ & 58 a & $\mathrm{L}$ \\
\hline P 32R21 & $57 \mathrm{~b}$ & $57 \mathrm{ab}$ & $58 \mathrm{a}$ & $59 \mathrm{a}$ & $58 \mathrm{a}$ & ns \\
\hline AG 1051 & $61 \mathrm{ab}$ & $63 \mathrm{a}$ & $59 \mathrm{a}$ & $55 \mathrm{a}$ & $60 \mathrm{a}$ & $\mathrm{L}$ \\
\hline BR 3123 & $66 \mathrm{a}$ & $62 \mathrm{a}$ & $56 \mathrm{a}$ & $57 \mathrm{a}$ & $60 \mathrm{a}$ & $\mathrm{L}$ \\
\hline BR 4157 & $54 \mathrm{~b}$ & $54 \mathrm{~b}$ & $53 \mathrm{a}$ & $53 \mathrm{a}$ & $54 \mathrm{~b}$ & ns \\
\hline Média & 60 & 59 & 56 & 56 & 58 & \\
\hline $\mathrm{P}>\mathrm{F}$ cultivar & $* *$ & $* *$ & $* *$ & $* *$ & $* *$ & $\mathrm{~L}$ \\
\hline
\end{tabular}

Tabela 63. Partição de $\mathrm{N}$ na fração espiga no estádio de florescimento em função de doses de nitrogênio e cultivar em Palmital 999/2000

\begin{tabular}{|c|c|c|c|c|c|c|}
\hline \multirow[b]{2}{*}{ Cultivar ${ }^{(1)}$} & \multicolumn{4}{|c|}{ Nitrogênio, $\mathrm{kg} \mathrm{ha}^{-1}$} & \multirow[b]{2}{*}{ Média } & \multirow{2}{*}{$\begin{array}{c}\mathrm{P}>\mathrm{F}^{(2)} \\
\text { nitrogênio }\end{array}$} \\
\hline & 0 & 60 & 120 & 180 & & \\
\hline \multicolumn{7}{|c|}{ - } \\
\hline XL 212 & $5 \mathrm{~b}$ & $9 \mathrm{ab}$ & $7 \mathrm{ab}$ & $8 \mathrm{ab}$ & $7 \mathrm{~b}$ & ns \\
\hline P 32R21 & $10 \mathrm{a}$ & $12 \mathrm{a}$ & $9 \mathrm{a}$ & $11 \mathrm{ab}$ & $11 \mathrm{a}$ & ns \\
\hline AG 1051 & $3 b$ & $4 \mathrm{c}$ & $3 \mathrm{~b}$ & $6 \mathrm{~b}$ & $4 \mathrm{c}$ & ns \\
\hline BR 3123 & $4 \mathrm{~b}$ & $6 \mathrm{bc}$ & $10 \mathrm{a}$ & $11 \mathrm{a}$ & $8 \mathrm{~b}$ & $\mathrm{~L}$ \\
\hline BR 4157 & $11 \mathrm{a}$ & $11 \mathrm{ab}$ & $11 \mathrm{a}$ & $10 a b$ & $11 \mathrm{a}$ & ns \\
\hline Média & 6 & 8 & 8 & 9 & 8 & \\
\hline $\mathrm{P}>\mathrm{F}$ cultivar & $* *$ & $* *$ & $* *$ & ns & $* *$ & $\mathrm{~L}$ \\
\hline
\end{tabular}

(T) Médias seguidas pela mesma letra na vertical não diferem pelo teste Tukey $5 \%$, Teste $\mathrm{F}:{ }^{*} \mathrm{e}^{*}=$ significativo a 5 e $1 \%$ respectivamente; ${ }^{(2)}$ Teste $\mathrm{F}: \mathrm{Q}=$ efeito quadrático, $\mathrm{L}=$ efeito linear e $\mathrm{ns}=$ não significativo a $5 \%$ de probabilidade; ${ }^{(2)}$

Tabela 64. Partição de N na fração folha total no estádio de maturação em função de doses de nitrogênio e cultivar em Palmital 1999/2000

\begin{tabular}{|c|c|c|c|c|c|c|}
\hline \multirow[b]{2}{*}{ Cultivar $^{(1)}$} & \multicolumn{4}{|c|}{ Nitrogênio, $\mathrm{kg} \mathrm{ha}^{-1}$} & \multirow[b]{2}{*}{ Média } & \multirow{2}{*}{$\begin{array}{c}\mathrm{P}>\mathrm{F}^{(2)} \\
\text { nitrogênio }\end{array}$} \\
\hline & 0 & 60 & 120 & 180 & & \\
\hline \multicolumn{7}{|c|}{ \% 10} \\
\hline XL 212 & $19 \mathrm{bc}$ & $18 \mathrm{~b}$ & $21 \mathrm{ab}$ & $23 \mathrm{ab}$ & $20 \mathrm{~b}$ & ns \\
\hline P 32R21 & $5 \mathrm{~d}$ & $7 \mathrm{c}$ & $14 \mathrm{~b}$ & $11 \mathrm{c}$ & $9 \mathrm{c}$ & $\mathrm{L}$ \\
\hline AG 1051 & $28 \mathrm{a}$ & $25 \mathrm{a}$ & $24 \mathrm{a}$ & $28 \mathrm{a}$ & $26 \mathrm{a}$ & ns \\
\hline BR 3123 & $24 \mathrm{ab}$ & $19 \mathrm{ab}$ & $20 \mathrm{ab}$ & $20 \mathrm{~b}$ & $20 \mathrm{~b}$ & ns \\
\hline BR 4157 & $16 \mathrm{c}$ & $18 \mathrm{ab}$ & $20 \mathrm{ab}$ & $23 a b$ & $19 \mathrm{~b}$ & $\mathrm{~L}$ \\
\hline Média & 18 & 17 & 20 & 21 & 19 & \\
\hline $\mathrm{P}>\mathrm{F}$ cultivar & $* *$ & $* *$ & $* *$ & $* *$ & $* *$ & $\mathrm{~L}$ \\
\hline
\end{tabular}

$\pi$ Médias seguidas pela mesma letra na vertical não diferem pelo teste Tukey $5 \%$, Teste $\mathrm{F}: \mathrm{e}^{*}=$ significativo a 5 e $1 \%$ respectivamente; ${ }^{(2)}$ Teste $\mathrm{F}: \mathrm{Q}=$ efeito quadrático, $\mathrm{L}=$ efeito linear e ns = não significativo a $5 \%$ de probabilidade; ${ }^{(2)}$ 
Tabela 65. Partição de N na fração grãos no estádio de maturação em função de doses de nitrogênio e cultivar em Palmital 1999/2000

\begin{tabular}{|c|c|c|c|c|c|c|}
\hline \multirow[b]{2}{*}{ Cultivar ${ }^{(1)}$} & \multicolumn{4}{|c|}{ Nitrogênio, $\mathrm{kg} \mathrm{ha}^{-1}$} & \multirow[b]{2}{*}{ Média } & \multirow{2}{*}{$\begin{array}{c}\mathrm{P}>\mathrm{F}^{(2)} \\
\text { nitrogênio }\end{array}$} \\
\hline & 0 & 60 & 120 & 180 & & \\
\hline & \multicolumn{6}{|c|}{ - } \\
\hline XL 212 & $49 \mathrm{~b}$ & $56 \mathrm{~b}$ & $53 \mathrm{a}$ & $49 \mathrm{~b}$ & $52 \mathrm{~b}$ & ns \\
\hline P 32R21 & $69 \mathrm{a}$ & $71 \mathrm{a}$ & $60 \mathrm{a}$ & $64 \mathrm{a}$ & $66 \mathrm{a}$ & $\mathrm{L}$ \\
\hline AG 1051 & $47 \mathrm{~b}$ & $52 \mathrm{~b}$ & $55 \mathrm{a}$ & $51 \mathrm{~b}$ & $51 \mathrm{~b}$ & ns \\
\hline BR 3123 & $43 \mathrm{~b}$ & $57 \mathrm{~b}$ & $59 \mathrm{a}$ & $55 \mathrm{ab}$ & $53 \mathrm{~b}$ & Q \\
\hline BR 4157 & $48 \mathrm{~b}$ & $49 \mathrm{~b}$ & $50 \mathrm{a}$ & $45 b$ & $48 \mathrm{~b}$ & ns \\
\hline Média & 51 & 57 & 55 & 53 & 54 & \\
\hline $\mathrm{P}>\mathrm{F}$ cultivar & $* *$ & $* *$ & $* *$ & $* *$ & $* *$ & Q \\
\hline
\end{tabular}

Tabela 66. Conteúdo de $\mathrm{N}$ nos grãos no estádio de maturação em função de doses de nitrogênio e cultivar em Palmital em 2000/01

\begin{tabular}{|c|c|c|c|c|c|c|}
\hline \multirow[b]{2}{*}{ Cultivar ${ }^{(1)}$} & \multicolumn{4}{|c|}{ Nitrogênio, $\mathrm{kg} \mathrm{ha}^{-1}$} & \multirow[b]{2}{*}{ Média } & \multirow{2}{*}{$\begin{array}{c}\mathrm{P}>\mathrm{F}^{(2)} \\
\text { nitrogênio }\end{array}$} \\
\hline & 0 & 60 & 120 & 180 & & \\
\hline & \multicolumn{5}{|c|}{$\mathrm{g} \mathrm{kg}^{-1}$} & \\
\hline XL 212 & $13,3 \mathrm{c}$ & $15,9 \mathrm{ab}$ & $16,0 \mathrm{~b}$ & $14,6 \mathrm{c}$ & $15,0 \mathrm{~b}$ & Q \\
\hline P 32R21 & $16,9 \mathrm{~b}$ & $18,4 \mathrm{a}$ & $17,8 \mathrm{ab}$ & $18,4 \mathrm{a}$ & $17,9 \mathrm{a}$ & $\mathrm{ns}$ \\
\hline AG 1051 & $13,0 \mathrm{c}$ & $4,7 \mathrm{~b}$ & $16,0 \mathrm{~b}$ & $15,6 \mathrm{bc}$ & $14,8 \mathrm{~b}$ & $\mathrm{~L}$ \\
\hline BR 3123 & $15,1 \mathrm{bc}$ & $15,8 \mathrm{ab}$ & $16,5 \mathrm{ab}$ & $17,2 \mathrm{a}-\mathrm{c}$ & $16,2 b$ & ns \\
\hline BR 4157 & $19,6 \mathrm{a}$ & $17,6 \mathrm{a}$ & $18,9 \mathrm{a}$ & $18,3 \mathrm{ab}$ & $18,6 \mathrm{a}$ & ns \\
\hline Média & 15,6 & 16,5 & 17,0 & 16,8 & 16,5 & $* *$ \\
\hline $\mathrm{P}>\mathrm{F}$ cultivar & $* *$ & $* *$ & $\mathrm{~ns}$ & $* *$ & $* *$ & $\mathrm{~L}$ \\
\hline
\end{tabular}


Em Votuporanga 99/00 e Palmital 99/00, a adubação nitrogenada aumentou todos os valores dos parâmetros de espiga, com exceção do número de espigas por planta (Anexos 12 e 13). Em Palmital 00/01 houve efeito apenas para número de fileira de grãos, massa de 100 grãos e massa de grãos por espiga.

O efeito do nitrogênio sobre a produtividade e a maioria dos parâmetros de espiga foi quadrático, confirmando a evidência de que a dose $180 \mathrm{~kg} \mathrm{ha}^{-1}$ foi excessiva. Os índices de produção de matéria seca na planta por unidade de nitrogênio nos tecidos e a relação entre o $\mathrm{N}$ acumulado na planta e grãos e o aplicado no fertilizante (eficiência agronômica do fertilizante) diminuíram com as doses de $\mathrm{N}$. Ou seja, o aumento da produtividade em função da adubação foi obtido com redução da eficiência de uso do $\mathrm{N}$ da planta e do fertilizante. Aparentemente, o aproveitamento do $\mathrm{N}$ do fertilizante é maior quando se aduba com menos nitrogênio em cobertura. Porém, a matéria seca dos grãos por unidade de $\mathrm{N}$ nos grãos aumentou de forma quadrática (aumento seguido de estabilização ou decréscimo) nos experimentos em que houve resposta da produtividade de grãos ao nitrogênio. Dessa forma, se a adubação não for excessiva, não há decréscimo da eficiência de uso de $\mathrm{N}$ nos grãos.

Como já mencionado, a proporção do $\mathrm{N}$ acumulado nos grãos em relação ao $\mathrm{N}$ acumulado na planta aumentou com as doses de nitrogênio (acúmulo de $\mathrm{N}$ no ciclo completo ou no subperíodo florescimento-maturação), exceto em Palmital 00/01. Nesse local houve decréscimo, com a adubação nitrogenada, da proporção do $\mathrm{N}$ acumulado nos grãos em relação ao acumulado na planta no ciclo todo. Isso demonstra, mais uma vez, que houve consumo de luxo na parte vegetativa, logo, o nitrogênio do solo era suficiente para o desenvolvimento da planta.

Em Palmital 00/01, quando calculou-se a proporção do $\mathrm{N}$ acumulado nos grãos em relação ao acumulado na planta especificamente depois do florescimento, houve aumento de eficiência com as doses de $\mathrm{N}$. Ë provável que o aumento relativo do $\mathrm{N}$ acumulado na planta depois do florescimento, em função da adubação nitrogenada, tenha ocorrido principalmente devido aos grãos. Os resultados das análises de solo amostrados após o florescimento revelaram que o aumento do $\mathrm{N}$ inorgânico no solo não perdurou durante todo o ciclo da cultura, especialmente em Votuporanga, em solo de 
textura média. Em Votuporanga 1999/00, o acúmulo relativo de $\mathrm{N}$ na planta depois do florescimento, expresso com porcentagem do $\mathrm{N}$ acumulado na maturação, reduziu com as doses de nitrogênio, assim como a relação entre o $\mathrm{N}$ acumulado nos grãos e o acumulado na planta no estádio de maturação. Talvez o sistema radicular tenha desenvolvido mais profundamente nas parcelas que receberam pouco adubo nitrogenado, permitindo a exploração de maior volume de solo nestas parcelas após o florescimento das plantas (maior absorção de $\mathrm{N}$ ), período em que o nitrogênio era escasso em todos os tratamentos. Já em Palmital, em latossolo roxo muito argiloso, a disponibilidade de $\mathrm{N}$ no solo após o florescimento das plantas foi maior do que em Votuporanga, possibilitando o aumento, com a adubação, do acúmulo relativo de $\mathrm{N}$ nas plantas no subperíodo florescimento-maturação. Esse nitrogênio acumulado depois do florescimento foi direcionado principalmente para as espigas.

\subsubsection{Curva de acúmulo}

As curvas de acúmulo de matéria seca e nutrientes indicam que houve um ponto de máximo a partir do qual ocorreu perda de matéria seca e nitrogênio (Figura 24), e que a perda foi mais acentuada e antecipada para o nitrogênio do que para a matéria seca. A redução de matéria seca e/ou nutrientes no final do ciclo de desenvolvimento das plantas foi relatada tanto nos trabalhos clássicos (Sayre, 1948; Hay et al., 1953) como nos mais recentes (Andrade et al., 1975a; Bassoi \& Reichardt, 1995; Vasconcellos et al., 1983). Essas perdas foram atribuídas por Sayre (1948) à perda de parte das folhas despedaçadas, e por Hay et al. (1953), a erros inevitáveis de amostragem do material nas condições de campo.

Wetselaar \& Farquhar (1980) citaram que é possível que as perdas de nitrogênio da parte aérea ocorram continuamente durante todos os estádios do crescimento das plantas, através da perda de tecidos nas raízes e na parte aérea, e perdas gasosas e lixiviação, pela chuva, orvalho ou água de irrigação, de compostos nitrogenados solúveis produzidos durante a sua translocação das folhas velhas para as novas. Contudo, essas perdas tornam-se aparentes somente quando maiores do que a taxa de absorção de 

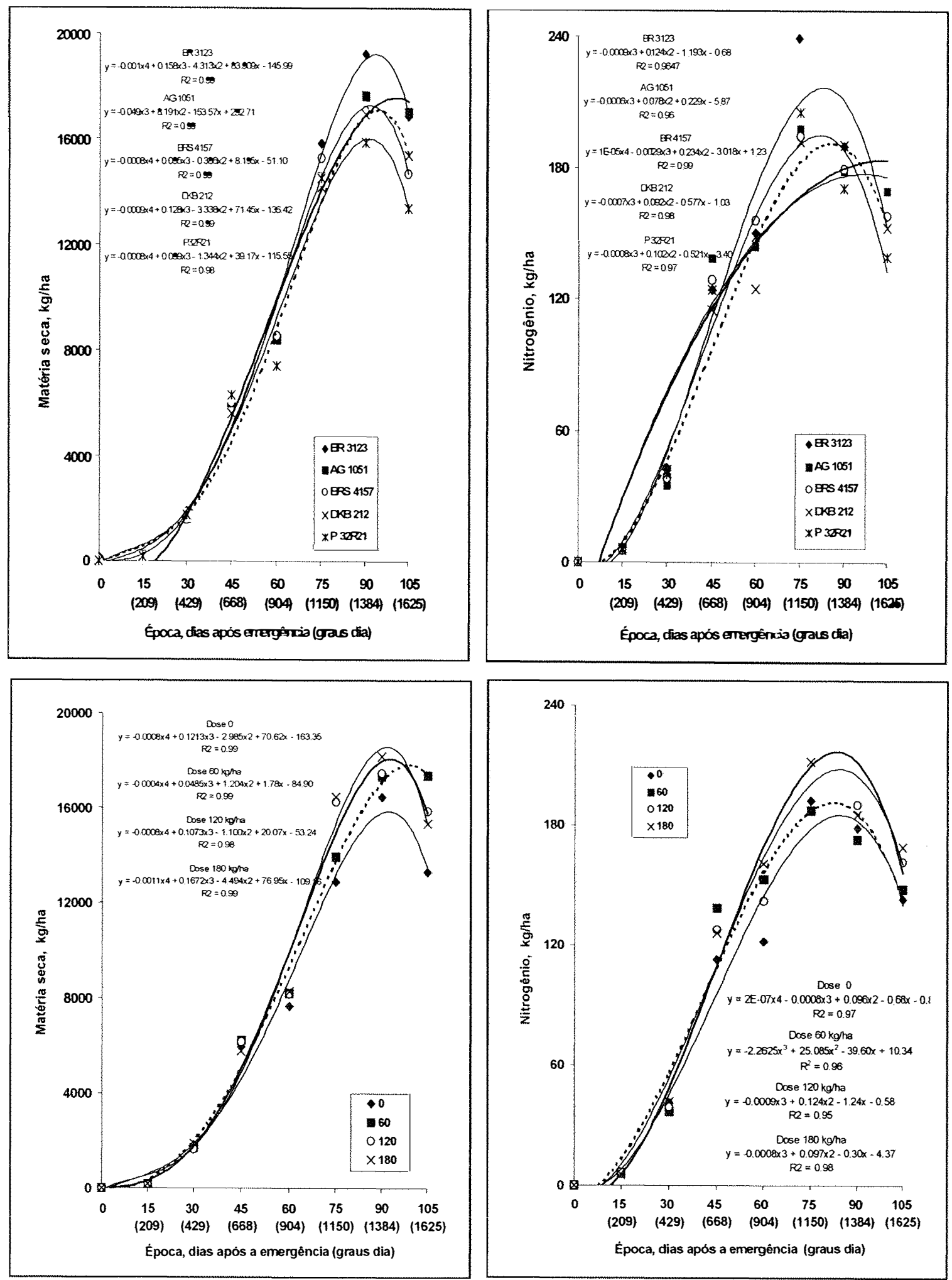

Figura 24. Curvas de acúmulo de matéria seca e nitrogênio em função de cultivares e doses de nitrogênio em Palmital (SP) em 2000/01. 
nitrogênio pelas raízes. Como as curvas foram construídas com resultados obtidos em intervalos relativamente longos, de 15 em 15 dias, sua precisão não é suficiente para diferenciar possíveis períodos de paralisação temporária do acúmulo de nutrientes, como observado por Karlen et al. (1988) para o nitrogênio no florescimento.

O valor médio estimado para o acúmulo de matéria seca, $16,2 \mathrm{Mg} \mathrm{ha}^{-1}$, é compatível com lavouras de alto potencial produtivo e coerente com as produtividades de grãos entre 9 e $10 \mathrm{Mg} \mathrm{ha}^{-1}$ das cultivares AG 1051 e BR 3123, que são adaptadas as semeaduras tardias. A razão entre o acúmulo de $\mathrm{N}$ e o acúmulo de matéria seca foi relativamente alta (dados não apresentados), se comparada aos valores obtidos por Andrade et al.(1975a,b), Vasconcellos et al. (1983), Hiroce et al. (1989) e Karlen et al. (1987). A alta disponibilidade de nitrogênio no solo, devido à adoção do sistema plantio direto por mais de cinco anos, e à adição do $\mathrm{N}$ como fertilizante, contribuiu para a elevada extração desse nutriente pela planta.

Ressalte-se que, no subprojeto sobre partição, para P 32R21, DKB 212 e BRS 4157 as colheitas no florescimento da ocorreram no primeiro terço do período entre os 45 e 60 dias da curva de acúmulo, enquanto para AG 1051 e BR 3123, deu-se no dia anterior ao período 60 dias. Os materiais de ciclo mais longo na maturação dos grãos (DKB 212 e AG 1051) foram os únicos colhidos com praticamente todas as folhas secas (dados apresentados no item anterior) e após a última amostragem referente à curva de acúmulo, aos 109 e 115 dias respectivamente.

Calcularam-se os valores máximos de matéria seca e nutrientes acumulados na planta inteira empregando-se as equações da curva de acúmulo e supondo-se que o início do florescimento ocorreu 1,5 dia antes do corte, para a AG 1051, e 2,5 dias, para as demais. O acúmulo de matéria seca e nitrogênio até o florescimento, em relação ao acúmulo máximo, foi baixo ( 40 a 43\%, dependendo da dose de $\mathrm{N}$ ) e elevado (62 a 66\%), respectivamente. Hanway (1962ab) observou que, quando a acumulação de matéria seca foi de $44 \%$, N, P e K acumularam, em média, $65 \%, 50 \%$ e $75 \%$, respectivamente, valores semelhantes aos de matéria seca e $\mathrm{N}$ do presente trabalho. Já os valores correspondentes obtidos por Sayre (1948) foram, em média, 50\%, 66\%, 58\% e 96\%. 
Karlen et al. (1987), em trabalho conduzido com cultivares modernas, irrigação e altíssimas populações de plantas, verificaram que, até o florescimento, o acúmulo de matéria seca foi, em média, de apenas $30 \%$ do máximo, ao passo que $\mathrm{N}, \mathrm{P}$ e $\mathrm{K}$ acumularam $60 \%, 46 \%$ e $80 \%$ do máximo, respectivamente. Devido a essa baixa acumulação de matéria seca em relação ao acúmulo de nutrientes, Karlen et al. (1987) sugeriram que no primeiro período, o acúmulo de nutrientes tenha sido maior do que nos estudos anteriores. Isso foi atribuído pelos autores a um possível efeito da melhoria no vigor dos híbridos nos primeiros estádios e ao fato de as populações de plantas terem sido muito altas.

Os valores do acúmulo máximo de MS e $\mathrm{N}$ foram semelhantes entre as doses de nitrogênio, mas o acúmulo máximo foi antecipado em cerca de cinco dias nos tratamentos 120 e $180 \mathrm{~kg} \mathrm{ha}^{-1}$ de $\mathrm{N}$ em comparação à testemunha e ao tratamento $60 \mathrm{~kg}$ $\mathrm{ha}^{-1}$ de N (dados não apresentados). As cultivares AG 1051 e BR 3123 apresentaram os maiores acúmulos de matéria seca, enquanto a BR 3123 acumulou mais N. Como já citado nos itens anteriores, e de acordo com os resultados do estudo sobre partição, essas cultivares apresentaram as maiores produtividades de grãos.

$\mathrm{Na}$ análise conjunta dos resultados de acúmulo nas épocas 30 a 90 dias (Tabela 67), as cultivares tropicais apresentaram maiores valores de MS, o que pode estar relacionado ao seu maior potencial produtivo de grãos nas condições do experimento. Embora as cultivares tropicais tenham apresentado maior acúmulo médio de matéria seca no período 30 a 90 dias e na estimativa de acúmulo máximo, não acumularam mais nitrogênio do que as temperadas. Já as cultivares que mostraram as menores produtividades de grãos, apresentaram como característica altos teores de $\mathrm{N}$ nos grãos, compensando possíveis reduções de acúmulo de $\mathrm{N}$ em função da menor produtividade.

As cultivares BR 4157 e P32R21 foram as mais precoces para atingir o máximo de acúmulo de MS, enquanto a BR 4157 foi a mais precoce para atingir o acúmulo máximo de N. Por outro lado, as estimativas dos acúmulos após o florescimento, expressos como porcentagem do total acumulado (dados não apresentados), indicaram que as cultivares temperadas acumularam $40 \%$ a mais de nitrogênio do que as tropicais, e valores semelhantes de matéria seca após o florescimento. 
Tabela 67. Valores médios do acúmulo de matéria seca e nitrogênio em plantas inteiras em cultivares de milho e resultados da análise de variância em função de épocas de amostragem (30, 45, 60, 75 e 90 dias após a emergência) e cultivares em Palmital 2000/01.

\begin{tabular}{|c|c|c|}
\hline Cultivar & Matéria seca & Nitrogênio \\
\hline & \multicolumn{2}{|c|}{$\mathrm{kg} \mathrm{ha}^{-1}$} \\
\hline \multicolumn{3}{|l|}{ Temperada } \\
\hline DKB 212 & 10222 & 136 \\
\hline P32R21 & 9887 & 138 \\
\hline Media & 10055 & 137 \\
\hline \multicolumn{3}{|l|}{ Tropical } \\
\hline AG 1051 & 10883 & 144 \\
\hline BR 3123 & 11424 & 151 \\
\hline BRS 4157 & 10542 & 143 \\
\hline Média & 10950 & 146 \\
\hline & \multicolumn{2}{|c|}{$\mathrm{P}>\mathrm{F}^{(1)}$} \\
\hline Época & $* *$ & $* *$ \\
\hline Cultivar & $* *$ & Ns \\
\hline temperada $\mathrm{x}$ tropical & $* *$ & Ns \\
\hline DKB212 x P32R21 & Ns & Ns \\
\hline AG $1051 \times$ BRs & Ns & Ns \\
\hline BR3123 x BRS4157 & $* *$ & Ns \\
\hline Época x Cultivar & $* *$ & Ns \\
\hline Bloco & $* *$ & $* *$ \\
\hline C. V. $(\%)$ & 6.8 & 13.6 \\
\hline
\end{tabular}

-T) Teste $\mathrm{F}:{ }^{* *}=$ significativo a $1 \%$ e $\mathrm{ns}=$ não significativo. 
Esses resultados corroboram as observações de Feil et al. (1992), que verificaram maior acúmulo de $\mathrm{N}, \mathrm{P}$ e $\mathrm{K}$ após o florescimento nas cultivares temperadas em relação às tropicais, e a de Osaki (1995a), que observou maior acúmulo de nitrogênio neste subperíodo nas temperadas. Por outro lado, a semelhança entre as cultivares quanto ao acúmulo de matéria seca após o florescimento não confirma as observações de Osaki (1995a) e contradiz as inferências sobre a superioridade das temperadas feitas na revisão bibliográfica, a partir de comparações de resultados obtidos entre países de clima temperado e de clima tropical. Provavelmente o baixo potencial produtivo das cultivares temperadas, por não estarem adequadamente adaptadas às condições ambientais, contribuiu para que tivessem padrão de acúmulo de matéria seca semelhante às tropicais.

Ao comparar os acúmulos de matéria seca e nitrogênio entre as doses de nitrogênio, verifica-se que os valores foram maiores quando se aplicou nitrogênio em cobertura, mas as diferenças entre as doses 120 e $180 \mathrm{~kg} \mathrm{ha}^{-1}$ foram inexpressivas. No estudo da partição não se verificou efeito do nitrogênio para massa seca de plantas no estádio de maturação, nem para a produtividade de grãos (Tabelas 55 e 58). Por outro lado, a adubação nitrogenada aumentou o acúmulo de $\mathrm{N}$ na planta nos estádios de florescimento e de maturação de grãos (Tabelas 54 e 56), de maneira linear e quadrática, respectivamente; na maturação, esse aumento foi acentuado apenas entre as doses 0 e 60 $\mathrm{kg} \mathrm{ha}^{-1}$ de N. Embora no trabalho de partição as diferenças entre as doses tenham sido mais evidentes no florescimento do que no estádio de maturação dos grãos, na presente curva de acúmulo a magnitude das diferenças foram maiores a partir do florescimento. É provável que a menor diferenciação dos tratamentos no estádio de maturação esteja relacionada ao efeito de possíveis perdas líquidas de massa e de nitrogênio na planta antes desse estádio.

Ao comparar as cultivares quanto ao acúmulo relativo no subperíodo florescimento-maturação fisiológica dos grãos, expresso como porcentagem do acúmulo até a maturação (item 4.4.1), evidenciou-se que a XL 212 apresentou um dos maiores acúmulos relativos de matéria seca e nitrogênio na planta depois do florescimento em Palmital 2000/01, assim como nos dois outros experimentos. Porém, em Palmital 2000/01, a P 32R21 apresentou um dos menores valores de acúmulo relativo de matéria 
seca e nitrogênio na planta depois do florescimento, ao contrário dos elevados valores revelados pelo método da estimativa do máximo acúmulo. É provável que inferências a partir da curva de acúmulo sejam mais realistas do que as obtidas pela determinação direta dos acúmulos nos estádios de florescimento e maturação fisiológica dos grãos devido às perdas líquidas de matéria seca e nitrogênio na planta antes da maturação.

Caso tenha ocorrido perda líquida de tecidos e nitrogênio antes da maturação fisiológica do grãos nos outros dois experimentos, à semelhança de Palmital 2000/01, as avaliações realizadas nesse estádio subestimaram o acúmulo máximo da planta e, por conseqüência, os valores de acúmulo relativo após o florescimento podem estar subestimados. Além disso, avaliou-se o florescimento quando todas as plantas já tinham emitido pendão, período no qual muitas delas já apresentavam espigas e tinham acumulado parte da matéria seca e nutrientes específicos do ciclo entre o florescimento e a maturação. Esse acúmulo anterior às avaliações deixou de ser contabilizado nos cálculos, reforçando ainda mais a possibilidade de os resultados dos acúmulos relativos de matéria seca e nitrogênio após o florescimento estarem subestimados em Palmital 1999/00 e Votuporanga 1999/00. 


\subsection{Qualidade Física dos Grãos}

A amplitude dos valores médios dos parâmetros avaliados nos diferentes experimentos indica que o ambiente influenciou a qualidade física dos grãos. Os valores do "test weight" foram maiores do que aqueles relatados em países de clima temperado, exceto em Palmital-Maturação, onde as espigas foram colhidas na maturidade fisiológica e debulhadas manualmente. Ressalte-se que as presentes análises foram realizadas em grãos com umidade menor do que as utilizadas na maioria dos trabalhos.

Aparentemente, os grãos foram menos duros em Palmital-Maturação do que em Votuporanga e Palmital. Além das diferenças quanto às condições ambientais, a grande proporção de cultivares com grãos do tipo dentado e semi-dentado contribuiu para os altos valores de grãos flutuantes em Palmital-Maturação.

A análise conjunta de Palmital e Votuporanga indicou interação significativa entre local e doses de nitrogênio para os parâmetros avaliados. Embora todos os parâmetros de dureza tenham apresentado resposta quadrática às doses de nitrogênio em Palmital, não foi possível observar que altas doses podem afetar negativamente a qualidade dos grãos. Em Votuporanga, apenas o teste de grãos boiantes e o "test weight" indicaram que a qualidade aumentou com a adubação nitrogenada, enquanto os demais parâmetros de dureza dos grãos não diferiram entre as doses de N. Em PalmitalMaturação, os dois parâmetros do "Stenvert Test" e a remoção por abrasão pelo equipamento TADD foi influenciada pelo nitrogênio, indicando que a dureza aumentou linearmente com a doses de nitrogênio. Ocorreu interação genótipos x nitrogênio apenas para um dos parâmetros do "Stenvert Test".

O quebramento sempre diminuiu com a adubação nitrogenada. Esse aumento de qualidade física, mesmo quando a resposta em produtividade não ocorre ou quando poucos parâmetros indicam o aumento da dureza dos grãos, estendem os resultados anteriores de Kniep and Mason (1989), Bauer and Carter (1986), e Johnson and Russell (1982), com milho colhido nos Estado Unidos da América do Norte, para as condições de cultivo tropicais. 
Tabela 68. Influência da adubação nitrogenada na qualidade física de grãos de milho em Palmital e Votuporanga em 2000/01.

\begin{tabular}{|c|c|c|c|c|c|c|c|}
\hline \multirow[b]{2}{*}{ Nitrogênio } & \multirow{2}{*}{$\begin{array}{l}\text { Grãos } \\
\text { boiantes }\end{array}$} & \multirow{2}{*}{$\begin{array}{l}\text { "Test } \\
\text { weight }\end{array}$} & \multirow[t]{2}{*}{ Densidade } & \multicolumn{2}{|c|}{ "Stenvert test" } & \multirow{2}{*}{$\begin{array}{l}\text { TADD } \\
\text { remoção }\end{array}$} & \multirow{2}{*}{$\begin{array}{l}\text { Suscetibilidade } \\
\text { quebramento }\end{array}$} \\
\hline & & & & Tempo & Altura & & \\
\hline \multirow[t]{2}{*}{$\mathrm{kg} \mathrm{ha}^{-1}$} & $\%$ & $\mathrm{~g} \mathrm{~L}^{-1}$ & $\mathrm{~g} \mathrm{~mL}^{-1}$ & $\mathrm{~s}$ & $\mathrm{~mm}$ & $\ldots \ldots$ & $\ldots \% \ldots \ldots \ldots$ \\
\hline & \multicolumn{7}{|c|}{ Palmital } \\
\hline 0 & 48 & 804 & 1.47 & 12.6 & 80 & 61 & 35.2 \\
\hline 60 & 30 & 807 & 1.48 & 14.2 & 78 & 57 & 31.9 \\
\hline 120 & 29 & 809 & 1.48 & 15.0 & 77 & 54 & 30.5 \\
\hline \multirow[t]{2}{*}{180} & 26 & 808 & 1.49 & 15.1 & 77 & 54 & 28.3 \\
\hline & \multicolumn{7}{|c|}{ Votuporanga } \\
\hline 0 & 24 & 821 & 1.51 & 14.2 & 80 & 53 & 33.0 \\
\hline 60 & 24 & 819 & 1.50 & 14.5 & 79 & 53 & 32.6 \\
\hline 120 & 23 & 817 & 1.50 & 14.7 & 79 & 53 & 30.3 \\
\hline \multirow[t]{2}{*}{180} & 21 & 818 & 1.51 & 14.4 & 80 & 53 & 31.1 \\
\hline & \multicolumn{7}{|c|}{$P>F^{(1)}$} \\
\hline $\mathrm{N}$ & $* *$ & ns & ns & $* *$ & $* *$ & $* *$ & $* *$ \\
\hline $\mathrm{N} *$ Cultivar & ns & ns & ns & ns & ns & ns & ns \\
\hline$N^{*}$ Local & $* *$ & $* *$ & $* *$ & $* *$ & $* *$ & $* *$ & $* *$ \\
\hline \multicolumn{8}{|l|}{ N Palmital } \\
\hline Linear & $* *$ & $* *$ & $* *$ & $* *$ & $* *$ & $* *$ & $* *$ \\
\hline Quadrático & $* *$ & $* *$ & $* *$ & $* *$ & $* *$ & $* *$ & $* *$ \\
\hline \multicolumn{8}{|c|}{ N Votuporanga } \\
\hline Linear & $*$ & $*$ & ns & ns & ns & ns & $* *$ \\
\hline Quadrático & ns & ns & ns & ns & ns & ns & ns \\
\hline C. V. $(\%)$ & 23.9 & 0.7 & 1.2 & 8.4 & 2.2 & 4.4 & 12.3 \\
\hline
\end{tabular}

$-(T)$ Teste $\mathrm{F}:{ }^{*}$ = significativo a $1 \%$ e ns = não significativo. 
Tabela 69. Influência da adubação nitrogenada na qualidade física de grãos de milho em Palmital,-Maturação em 2000/01.

\begin{tabular}{|c|c|c|c|c|c|c|c|}
\hline \multirow[b]{2}{*}{ Nitrogênio } & \multirow{2}{*}{$\begin{array}{l}\text { Grãos } \\
\text { boiantes }\end{array}$} & \multirow{2}{*}{$\begin{array}{l}\text { "Test } \\
\text { weight }\end{array}$} & \multirow[t]{2}{*}{ Densidade } & \multicolumn{2}{|c|}{ "Stenvert test" } & \multirow{2}{*}{$\begin{array}{l}\text { TADD } \\
\text { remoção }\end{array}$} & \multirow{2}{*}{$\begin{array}{l}\text { Suscetibilidade } \\
\text { quebramento }\end{array}$} \\
\hline & & & & Tempo & Altura & & \\
\hline $\mathrm{kg} \mathrm{ha}^{-1}$ & $\%$ & $\mathrm{~g} \mathrm{~L}^{-1}$ & $\mathrm{~g} \mathrm{~mL} \mathrm{~mL}^{-1}$ & S & $\mathrm{mm}$ & $\ldots \ldots$. & $\ldots \% \ldots \ldots \ldots$ \\
\hline 0 & 63 & 752 & 1.56 & 12.2 & 86 & 64 & 25.5 \\
\hline 60 & 63 & 740 & 1.53 & 12.0 & 86 & 60 & 23.7 \\
\hline 120 & 61 & 742 & 1.56 & 12.6 & 84 & 57 & 24.2 \\
\hline \multirow[t]{2}{*}{180} & 63 & 746 & 1.56 & 13.0 & 85 & 58 & 21.9 \\
\hline & \multicolumn{7}{|c|}{$P>F^{(1)}$} \\
\hline $\mathrm{N}$ Linear & ns & ns & ns & $* *$ & $* *$ & $* *$ & $* *$ \\
\hline N Quadrático & ns & $\mathrm{ns}$ & ns & $\mathrm{ns}$ & ns & ns & $\mathrm{ns}$ \\
\hline $\mathrm{N}^{*}$ Cultivar & ns & ns & ns & ns & $* *$ & ns & ns \\
\hline C. V. $(\%)$ & 13.2 & 3.3 & 3.32 & 7.5 & 1.4 & 10.2 & 14.3 \\
\hline
\end{tabular}

(1) Teste $\mathrm{F}:{ }^{* *}=$ significativo a $1 \%$ e ns = não significativo. 


\subsection{Considerações Finais}

Nos latossolos roxos, quando os teores médios de $\mathrm{N}$ inorgânico até $40 \mathrm{~cm}$ de profundidade foram maiores do que $11 \mu \mathrm{g} \mathrm{g}^{-1}$, não houve resposta à adubação nitrogenada de cobertura, sugerindo que neste tipo de solo a determinação de $\mathrm{N}$ inorgânico nas camadas 0-20 e 20-40 cm pode auxiliar na predição da resposta do milho à adubação nitrogenada.

$\mathrm{O}$ aumento do teor de $\mathrm{N}$ no solo com a adubação não perdurou durante todo o ciclo da cultura em Votuporanga, em solo de textura média. Nessa localidade, a produtividade de grãos e o acúmulo relativo de $\mathrm{N}$ depois do florescimento foram menores do que em Palmital no ano que não houve o veranico. Isso foi devido, entre outros fatores, aos menores teores de $\mathrm{N}$ na planta decorrentes da menor disponibilidade de $\mathrm{N}$ no solo.

No subprojeto Genótipos x Nitrogênio, quando se procedeu a analise dos sete experimentos individualmente, constatou-se interação significativa entre genótipos e doses de nitrogênio para a produtividade grãos em três experimentos, e para exportação de $\mathrm{N}$, em dois. Nas análises conjuntas dos experimentos, sempre houve interação genótipos x nitrogênio, proporcionando melhor diferenciação das cultivares quanto à resposta ao nitrogênio. Poucas cultivares apresentaram resposta diferenciada, destacando-se a XL 212, como pouco responsiva, e as IAC VI, BR 3123 e 8410, como muito responsivas.

A diferenciação das cultivares quanto ao nível de resposta à adubação nitrogenda é bastante complexa devido, entre outros fatores, à adaptação do germoplasma às condições edafoclimáticas regionais, que influenciam a expressão do potencial produtivo. Sugere-se que os estudos da interação genótipos x nitrogênio sejam feitos apenas com cultivares comprovadamente adaptadas ao ambiente. A análise conjunta de experimentos em mais de um local e durante dois anos agrícolas parece diluir possíveis efeitos de fatores não controlados no desempenho específico de uma cultivar em dado ambiente (ex.: temperatura do ar, estresse hídrico e compactação do solo), possibilitando melhor diferenciação das cultivares contrastantes quanto à resposta ao nitrogênio. 
Não houve interação genótipo x nitrogênio para o conteúdo de nitrogênio nos grãos; P 32R21, BR 4157, 8410, C 333B e IAC V1 tiveram os maiores valores, e a AG 1051 e XL 212, os menores. De maneira geral, as cultivares com mais $\mathrm{N}$ nos grãos foram as mais responsivas ao nitrogênio, com exceção da C 333B. No entanto, elevados teores de $\mathrm{N}$ nos grãos não foi uma premissa para que a cultivar se destacasse quanto à resposta ao N; a BR 3123 não se diferenciou das demais quanto ao $\mathrm{N}$ nos grãos, e foi muita responsiva à adubação.

$\mathrm{O}$ teor de $\mathrm{N}$ nos grãos aumentou até a maior dose de $\mathrm{N}$, enquanto a produtividade estabilizou ou decresceu a partir de um ponto de máximo; em alguns casos ocorreu exportação desnecessária de nitrogênio nas maiores doses desse nutriente. Do ponto de vista da qualidade dos grãos, a adubação nitrogenada sempre aumentou os teores de $\mathrm{N}$ e reduziu a suscetibilidade ao quebramento dos grãos, mesmo quando não houve resposta em termos de produtividade. Essa melhoria da qualidade física dos grãos indica que se pode empregar maiores doses de $\mathrm{N}$ em situações em que a cultivar apresenta elevada suscetibilidade ao quebramento de grãos.

A diferenciação das respostas das cultivares em função do parcelamento do $\mathrm{N}$ na base e em cobertura, assim como suas diferentes características quanto ao acúmulo relativo de $\mathrm{N}$ após o florescimento, sugere que as recomendações de quando aplicar o fertilizante podem ou devem ser diferenciadas para algumas cultivares.

Constataram-se poucas interações entre cultivares e doses de nitrogênio para os parâmetros acúmulo, partição e eficiência de uso de $\mathrm{N}$ na planta. Porém, por ser complexa a diferenciação das cultivares quanto à resposta da produtividade ao $\mathrm{N}$, os estudos de caracterização das cultivares per se quanto ao acúmulo, partição e efíciência de uso do $\mathrm{N}$ na planta auxiliaram na compreensão dessas diferenças.

Confirmou-se que os materiais com germoplasma predominantemente temperado diferem dos tropicais quanto ao acúmulo e partição do nitrogênio. Nos experimentos com maior produtividade de grãos, as cultivares tropicais AG 1051 e BR 3123 apresentaram a menor partição de $\mathrm{N}$ no colmo por ocasião da maturação. As cultivares temperadas, por sua vez, apresentaram os maiores teores de $\mathrm{N}$ na planta inteira no estádio de florescimento (XL 212) ou maturação (XL 212 e P 32R21). A BR 4157, 
melhorada em condições de baixa disponibilidade de $\mathrm{N}$ no solo, apresentou elevados teores de $\mathrm{N}$ no colmo na maturação e, nos experimentos onde o $\mathrm{N}$ inorgânico do solo não sofreram acentuada redução após a segunda cobertura (Palmital 1999/00 e 2000/01), destacou-se também pelos teores de $\mathrm{N}$ na planta inteira.

Houve tendência de as cultivares XL 212 e AG 1051 apresentarem maior acúmulo relativo de matéria seca e nitrogênio no subperíodo florescimento-maturação, expresso como porcentagem do acúmulo total. Porém, no estudo da curva de acúmulo, verificou-se que as cultivares temperadas XL 212 e P 32R21 acumularam mais $\mathrm{N}$ depois do florescimento do que as demais. Osaki (1995a) também verificou que, em plantas de milho tropical, a maior quantidade do nitrogênio dos grãos foi translocada das folhas e do colmo, enquanto no milho temperado foi absorvida pelas raízes durante a maturação Essa discrepância ocorreu porque, provavelmente, o acúmulo total foi subestimado no trabalho de partição devido às perdas de matéria seca e nitrogênio antes da maturação fisiológica dos grãos, estádio no qual se procedeu a avaliação do acúmulo que caracterizou o ciclo completo das plantas.

As cultivares P32R21 e BR 3123, consideradas muito responsivas à adubação nitrogenada, tiveram o menor ciclo relativo entre o florescimento e a maturação dos grãos, enquanto a AG 1051, altamente produtiva mesmo na ausência de N, e a XL 212, pouco responsiva ao $\mathrm{N}$, tiveram os maiores períodos relativos.

O aumento da produtividade em função da adubação foi obtido com redução da eficiência de uso do $\mathrm{N}$ da planta e do fertilizante. Porém, ao mesmo tempo, a proporção de $\mathrm{N}$ acumulado nos grãos em relação ao total da planta e a eficiência de uso do $\mathrm{N}$ nos grãos (unidade de massa por unidade de N) aumentaram com as adubações. A partição de massa seca na fração espiga aumentou, e a na fração colmo diminuiu com as doses de $\mathrm{N}$ nos experimentos em que a produtividade de grãos aumentou com a adubação de cobertura.

Nos experimentos com maior produtividade de grãos, as plantas apresentaram maior acúmulo relativo de matéria seca e nitrogênio depois do florescimento. Porém, as cultivares com maior acúmulo relativo de matéria seca e de nitrogênio depois do florescimento, como a XL 212 e a AG 1051, não foram sempre as mais produtivas. 
Cultivares melhoradas em condições de estresse de nitrogênio, como a BR 4157, podem não se adaptar em condições regionais. Devido à baixa adaptação produtiva da BR 4157 aos ambientes em que os experimentos foram realizados, essa variedade não expressou suas vantagens de eficiência de uso do $\mathrm{N}$ nos tratamentos sem e com adubação nitrogenada de cobertura. Embora a BR 4157 tenha se destacado quanto aos teores de $\mathrm{N}$ nos grãos, não apresentou elevada partição do $\mathrm{N}$ da planta nos grãos.

Deve-se lembrar que o presente trabalho foi desenvolvido em áreas cultivadas no sistema de plantio direto por mais de três anos. No sistema plantio direto estabilizado, especialmente nos solos argilosos, as chances de estresse severo de nitrogênio podem ser menores do que no sistema convencional, em função da mineralização do $\mathrm{N}$ da matéria orgânica acumulada nas camadas superficiais do solo (Sá, 1995b). Friesen et al. (2001) e Banziger et al. (2000) citaram que os programas de melhoramento em condições de estresse de $\mathrm{N}$ são efetivos para lançar cultivares adaptadas a condições de estresse severo desse nutriente. Por outro lado, tem-se verificado que, geralmente, os híbridos de maior potencial produtivo em condições ambientais favoráveis são também os mais produtivos em condições de estresse - geralmente moderado para N (Carlone \& Russel, 1987 e Duvick 1984).

Outro ponto é que a definição do termo "eficiência" é ampla, variando de maior proporção do $\mathrm{N}$ da planta nos grãos ao maior acúmulo de massa por unidade de $\mathrm{N}$ nos tecidos, incluindo também aspectos de acúmulo relativo no subperíodo florescimentomaturação.

Nos casos dos agricultores que utilizam grãos de milho em sua propriedade, o emprego de cultivar com elevado teor de $\mathrm{N}$ nos grãos e, freqüentemente, maior relação $\mathrm{N}$ acumulado nos grãos/ $\mathrm{N}$ na planta, pode ser desejável devido aos maiores teores de proteína. Porém, quando os grãos são comercializados, não há compensação financeira pela maior exportação de N. Assim, do ponto de vista agronômico, é fundamental que a eficiência esteja associada também com elevadas produtividades. Nesse particular, o conhecimento da adaptação ambiental e da resposta da cultivar ao $\mathrm{N}$ pode ser mais relevante do que o da eficiência de uso do $\mathrm{N}$, porque possibilita inferências quanto ao potencial produtivo em diferentes níveis de manejo da fertilidade do solo. 


\section{CONCLUSÕES}

1) Dentre as treze cultivares estudadas, XL 212 destacou-se por apresentar baixa resposta da produtividade de grãos ao nitrogênio aplicado em cobertura, e IAC Vl, BR 3123 e 8410 , por apresentarem alta resposta.

2) Os padrões de exigência de $\mathrm{N}$ durante os estádios iniciais de desenvolvimento variaram entre as cultivares: para a C 333B, o aumento na produção de grãos com a aplicação de $\mathrm{N}$ em cobertura não foi influenciado pela adubação de semeadura, enquanto para a BR 3123 a resposta foi maior quando o $\mathrm{N}$ foi aplicado na semeadura.

3) As cultivares temperadas XL 212 e P $32 \mathrm{R} 21$ apresentaram os maiores teores de $\mathrm{N}$ na planta inteira no estádio de florescimento e/ou maturação de grãos, e as tropicais AG 1051 e BR 3123, as maiores partições de $\mathrm{N}$ no colmo na maturação e as maiores eficiências de uso do $\mathrm{N}$ na planta (massa por unidade de $\mathrm{N}$ ).

4) As cultivares $P 32 R 21$ e BR 3123, muito responsivas ao $N$, apresentaram os menores ciclos relativos após o florescimento, expresso como porcentagem do ciclo total até a maturação.

5) O aumento da produtividade em função da adubação foi obtido com a redução da eficiência de uso do $\mathrm{N}$ na planta (unidade de massa na planta por unidade de $\mathrm{N}$ ) e do fertilizante ( $\mathrm{N}$ acumulado na planta / $\mathrm{N}$ aplicado) e, ao mesmo tempo, com o aumento da partição de $\mathrm{N}$ nos grãos ( $\mathrm{N}$ acumulado nos grãos/ $\mathrm{N}$ na planta) e da eficiência de uso do $\mathrm{N}$ nos grãos. 
6) A partição de massa seca na fração espiga aumentou, e na fração colmo diminuiu com as doses de $\mathrm{N}$ nos experimentos em que a produtividade de grãos aumentou com a adubação nitrogenada.

7) A proporção do $\mathrm{N}$ total acumulado na planta depois do florescimento variou de $19,6 \% \mathrm{a}$ $39,8 \%$, dependendo da cultivar e dose de $\mathrm{N}$.

8) A adubação nitrogenada melhorou a qualidade dos grãos, aumentando os teores de $\mathrm{Ne}$ reduzindo a suscetibilidade ao quebramento, mesmo quando não houve aumento de produtividade.

9) Predominou a forma $\mathrm{N}$-nitrato no período em que a adubação aumentou o $\mathrm{N}$ inorgânico no solo.

10) Em solo textura média não foram encontrados resíduos da adubação nitrogenada por ocasião do florescimento do milho, o contrário ocorrendo em solo argiloso quando a dose foi igual ou superior a $120 \mathrm{~kg} \mathrm{ha}^{-1}$. 
ANEXOS 

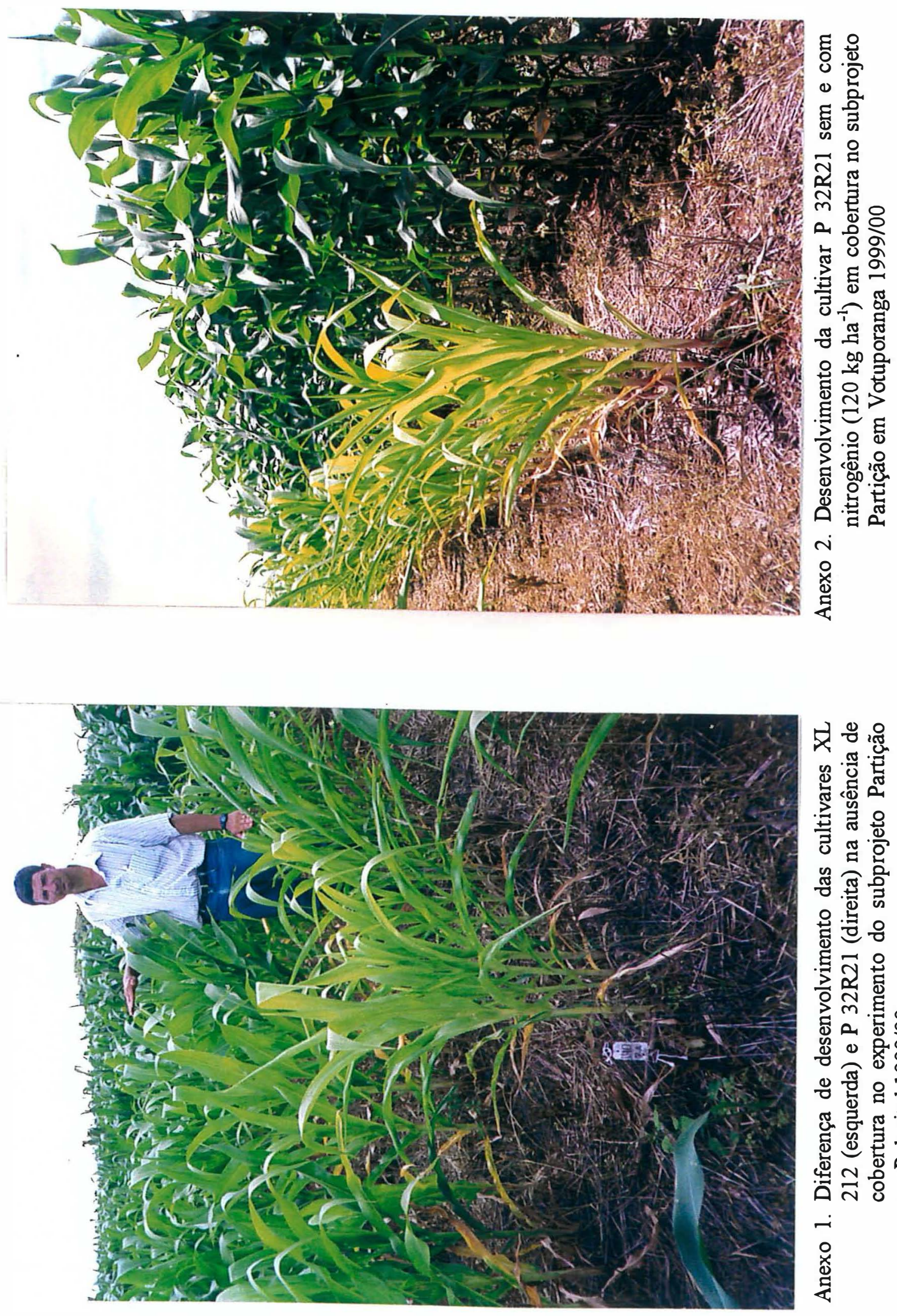

구 윯

कृ

. 胥 ᄋ

늘 ส

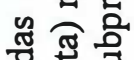

म

눔흥ㅇㅁ

구 0

고름

$\rho$ m

ธี

घे 0 앙요

ส 0

융 웅

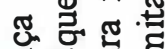

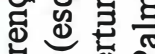

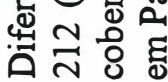

安 


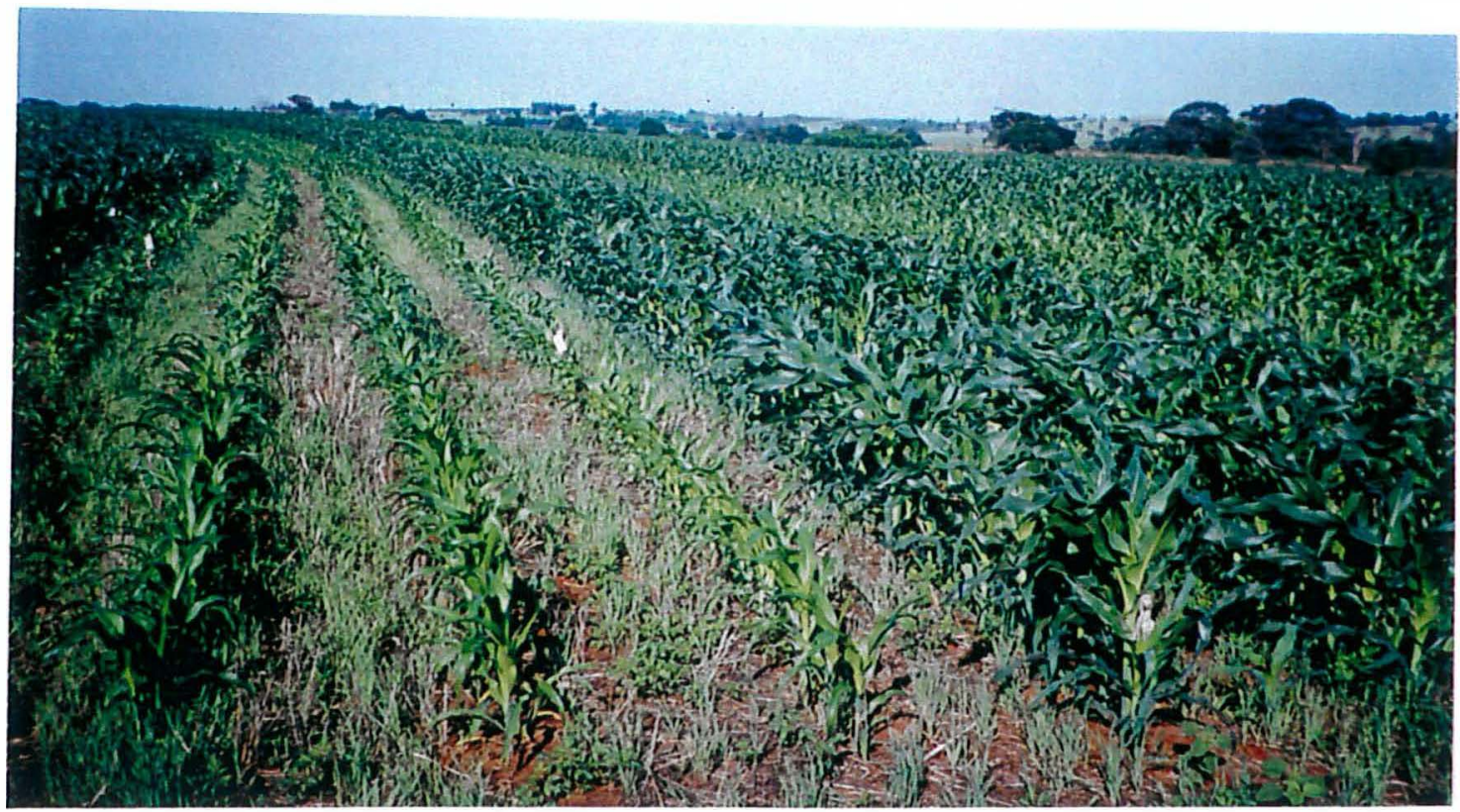

Anexo 3. Aspecto geral do experimento do subprojeto Parcelamento em Votuporanga 1998/99 mostrando a diferença das parcelas sem e com $\mathrm{N}$ na semeadura

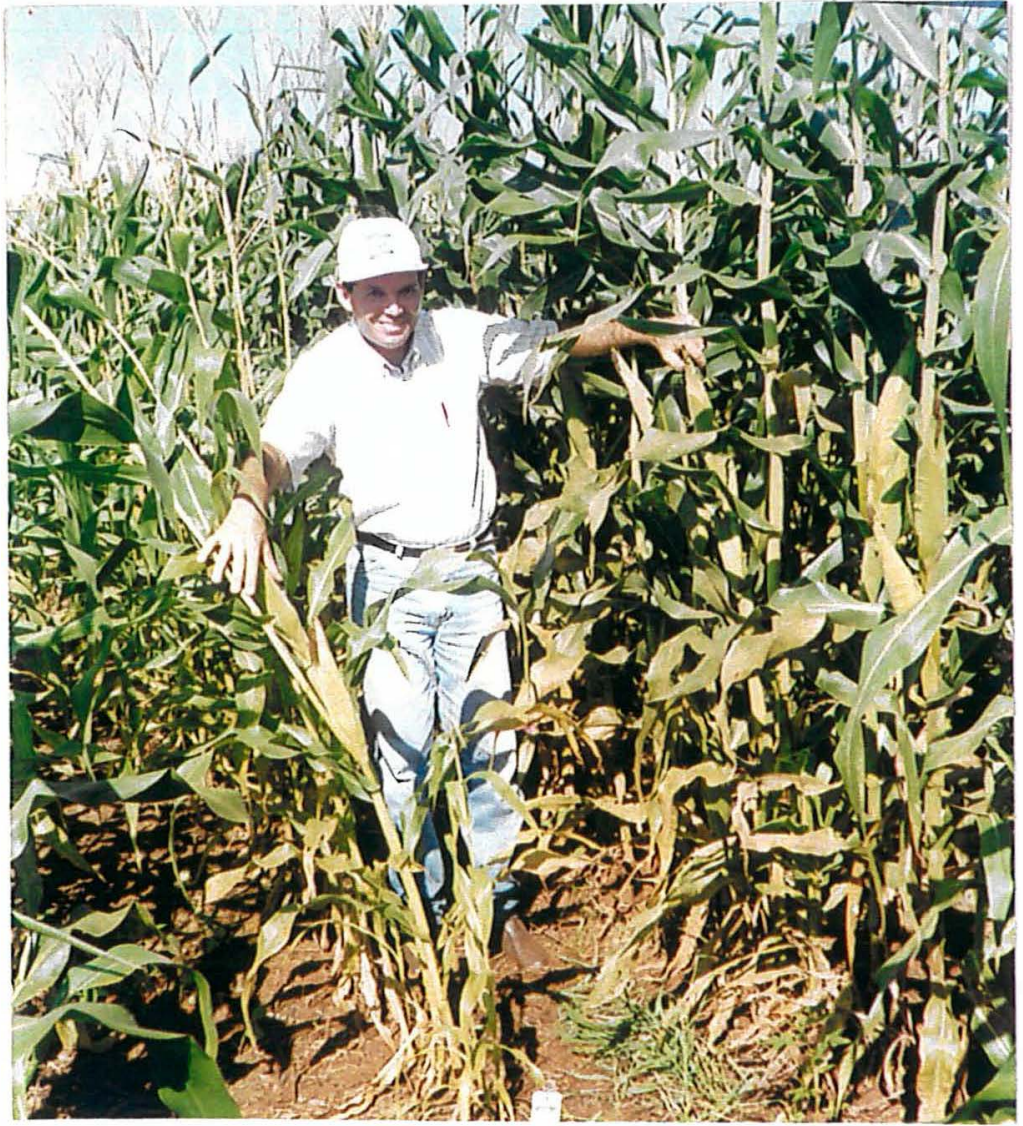

Anexo 4. Desenvolvimento da BR 3123 sem e com N na semeadura e ambos com $\mathrm{N}$ em cobertura em Votuporanga 1998/99 

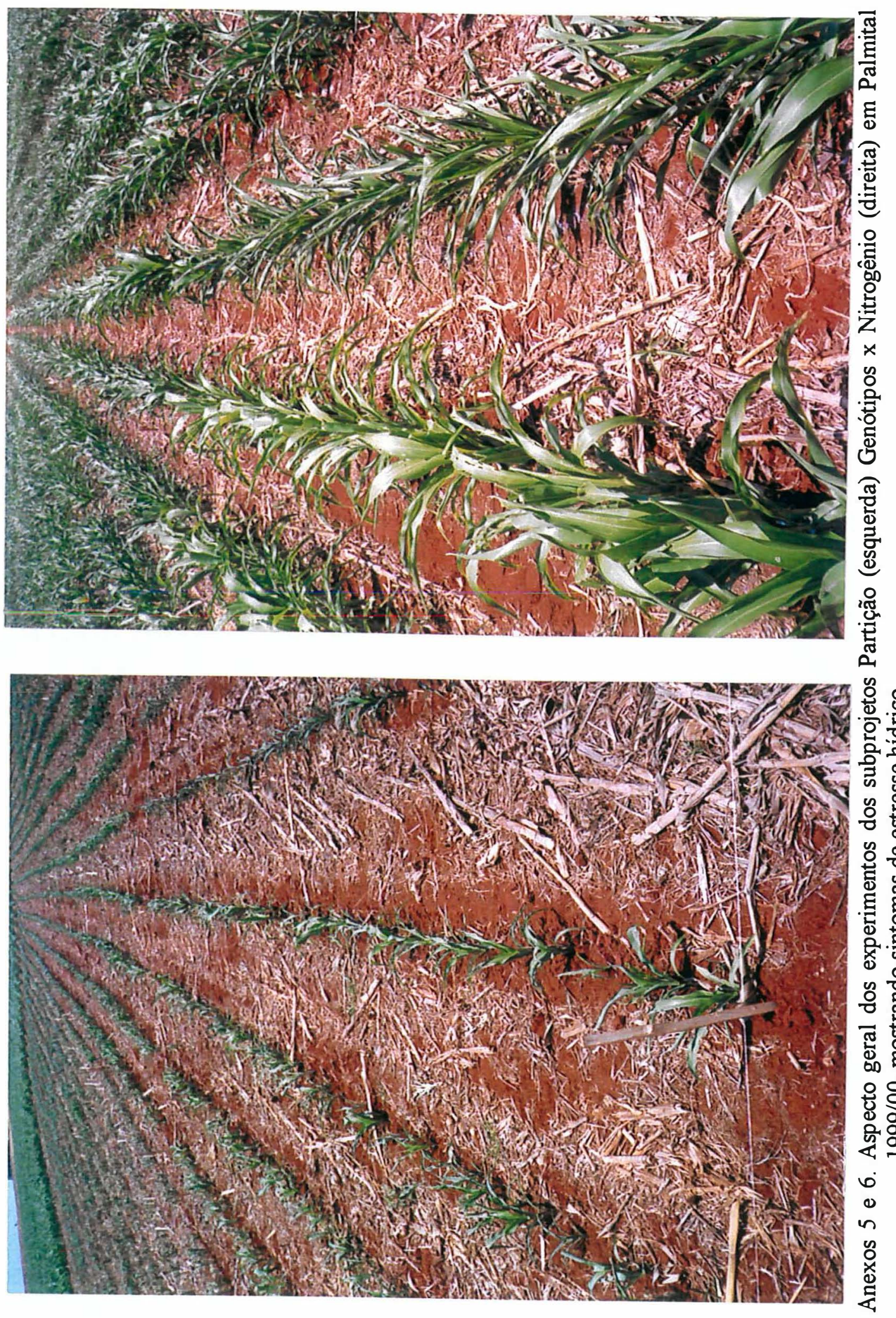

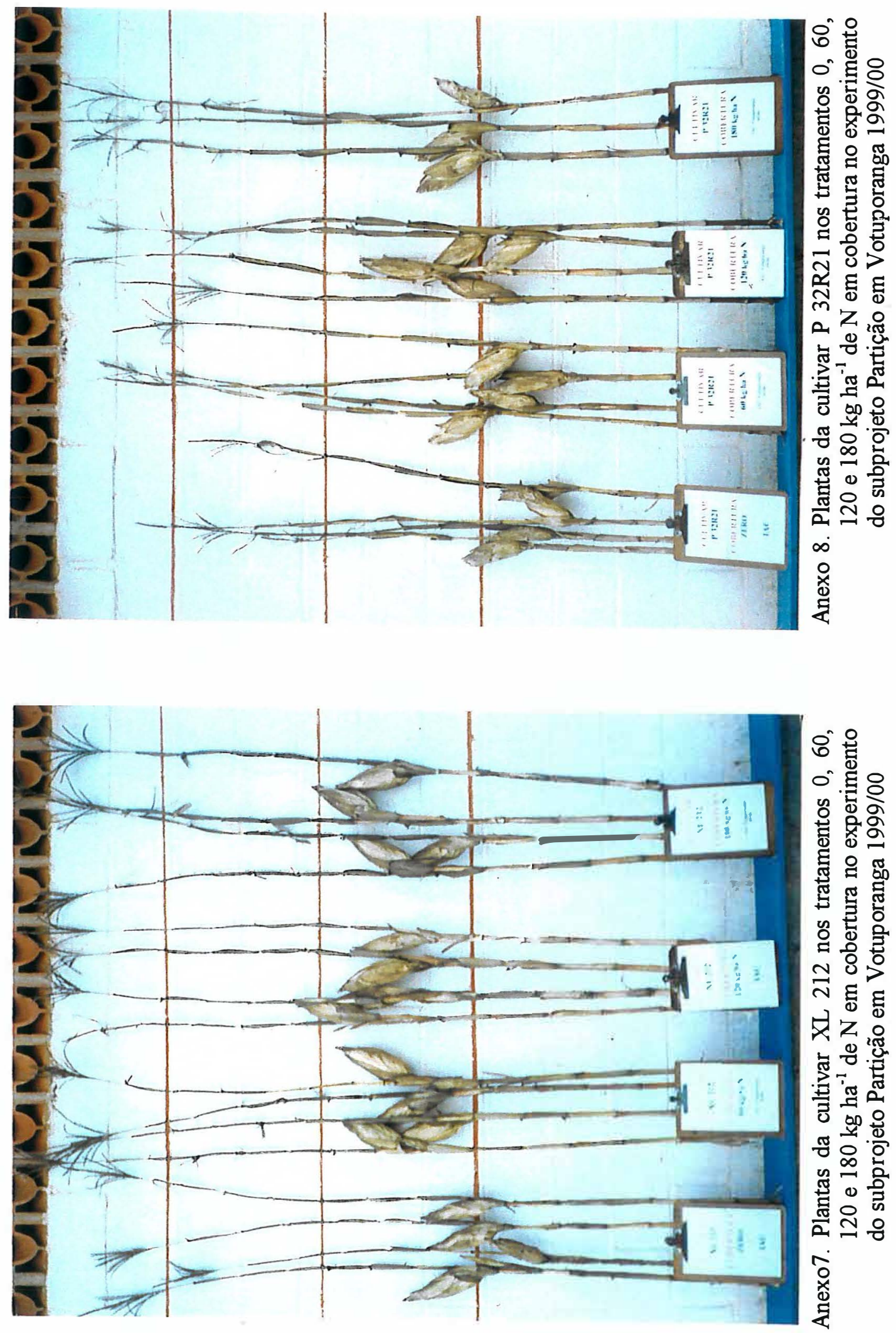


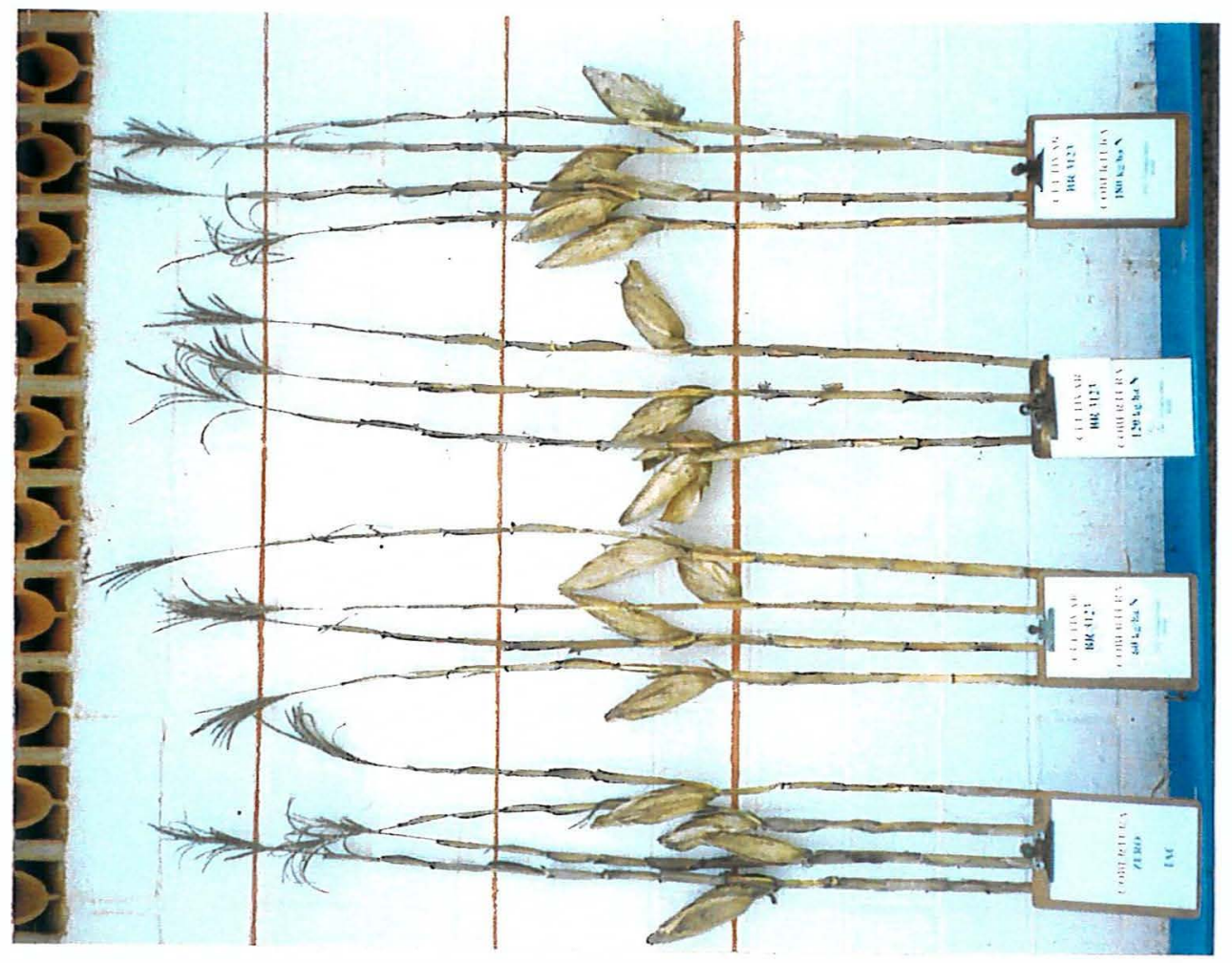

ㅇํㅇ움

○. 용

닝

룽응

్ㅐ용

ส

可

영

응

त $0>$

ำ 통

品乙。

농얼

.

ठี สㅇำ

ชิ

잉ㅁㅁ

편

क्ष क

-

으

这

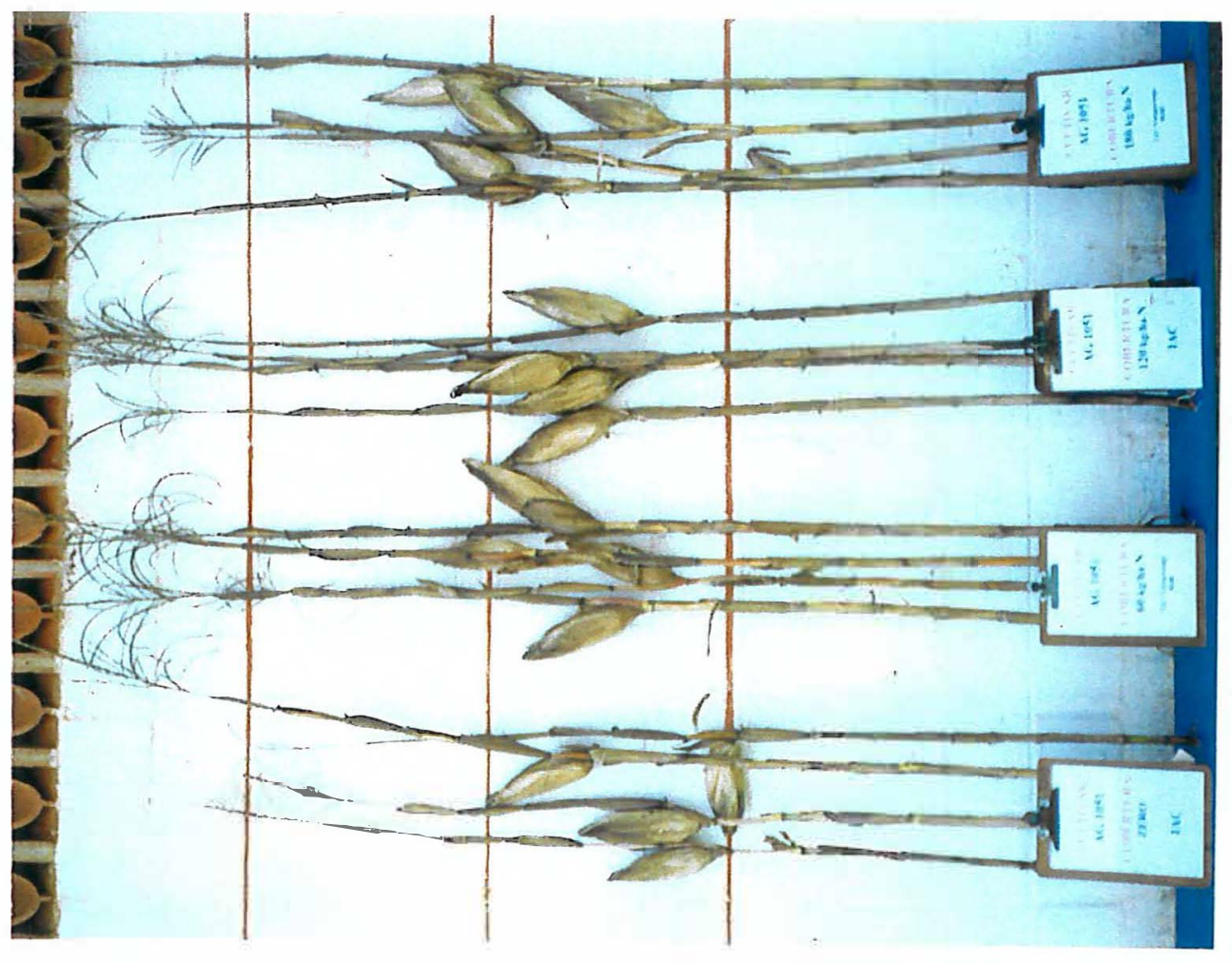

ㅇํ윰

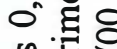

웧

붕 응

్ㅠ 용

전

要

응 응

ㄷํㅇํํ

으를

○) 이

云乙。

요용

근

"ส

ర人 of

정 웅

ฯ

荧。

졍으

덩ㅇㅁ

a

일 


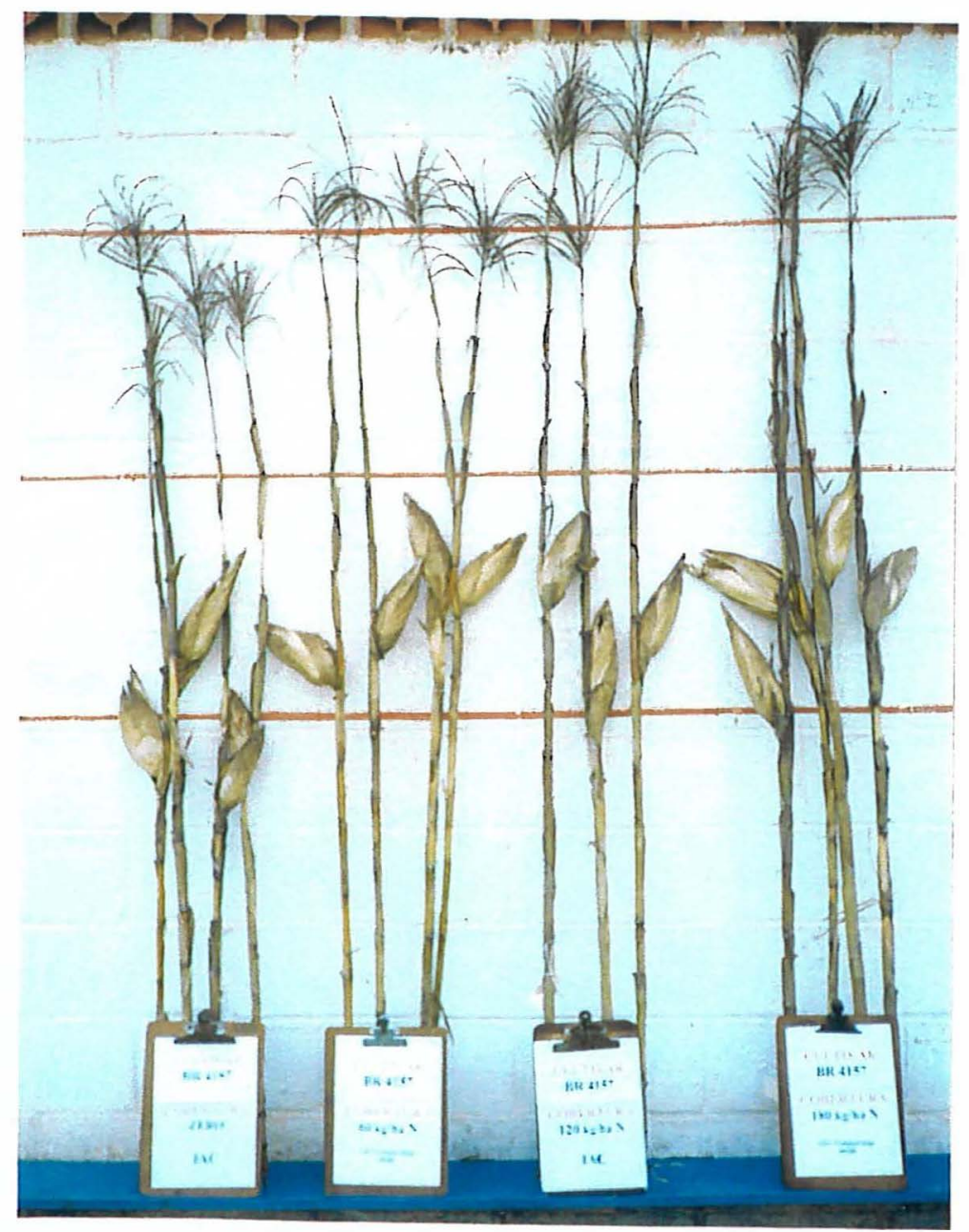

Anexo 11. Plantas da cultivar BR 4157 nos tratamentos 0,60 , 120 e $180 \mathrm{~kg} \mathrm{ha}^{-1}$ de $\mathrm{N}$ em cobertura no experimento do subprojeto Partição em Votuporanga 1999/00 

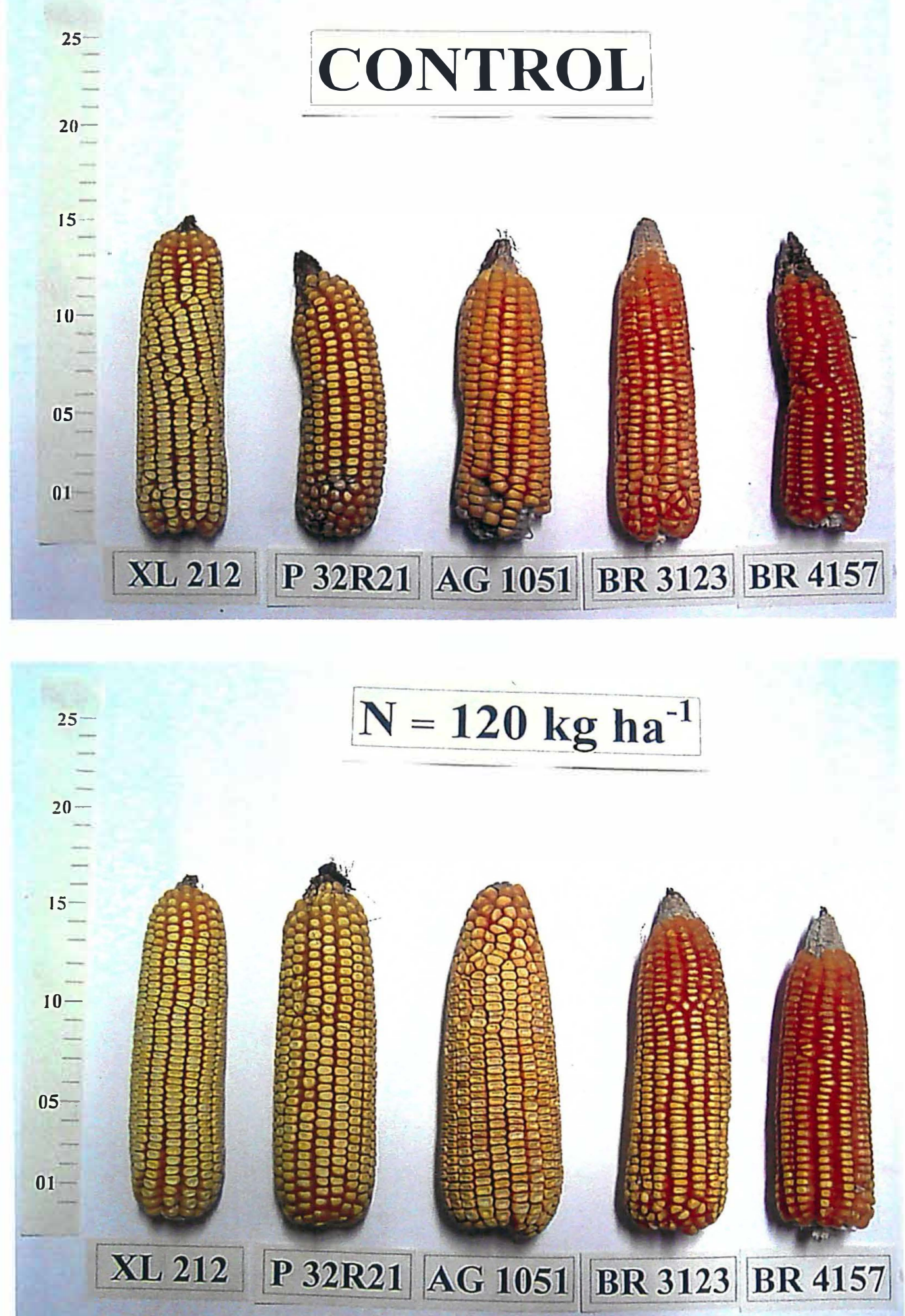

Anexos 12 e 13. Aspecto das espigas das cultivares de milho no subprojeto Partição, nas doses 0 e $120 \mathrm{~kg} \mathrm{ha}^{-1}$ de $\mathrm{N}$ em cobertura 


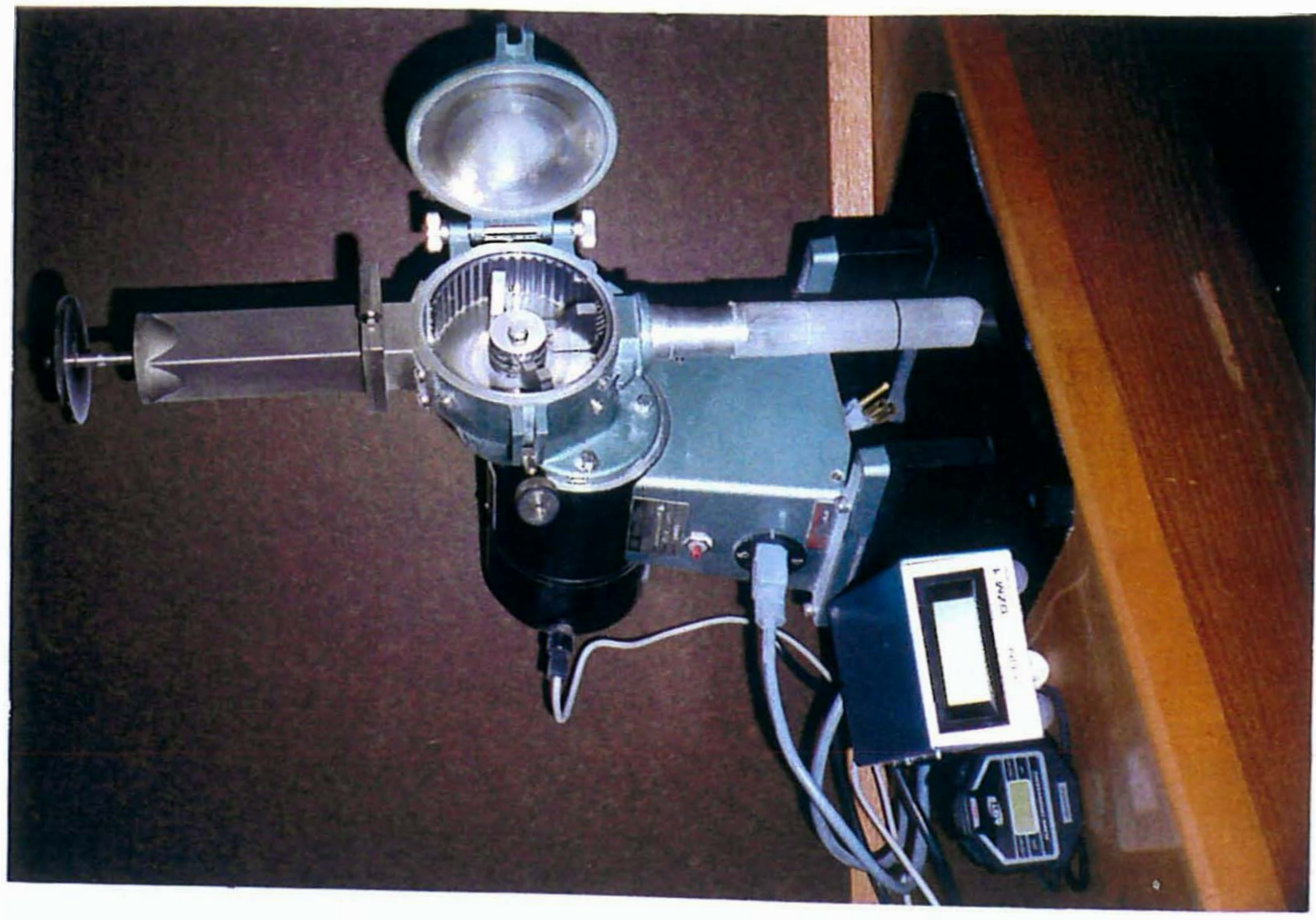

-

iั

$\stackrel{\text { N }}{*}$

동

在

फัّ

: 즘

응 징

चे

空

ข

웜

졸 을

๑

ช

응

吉包

之잉

ก

这

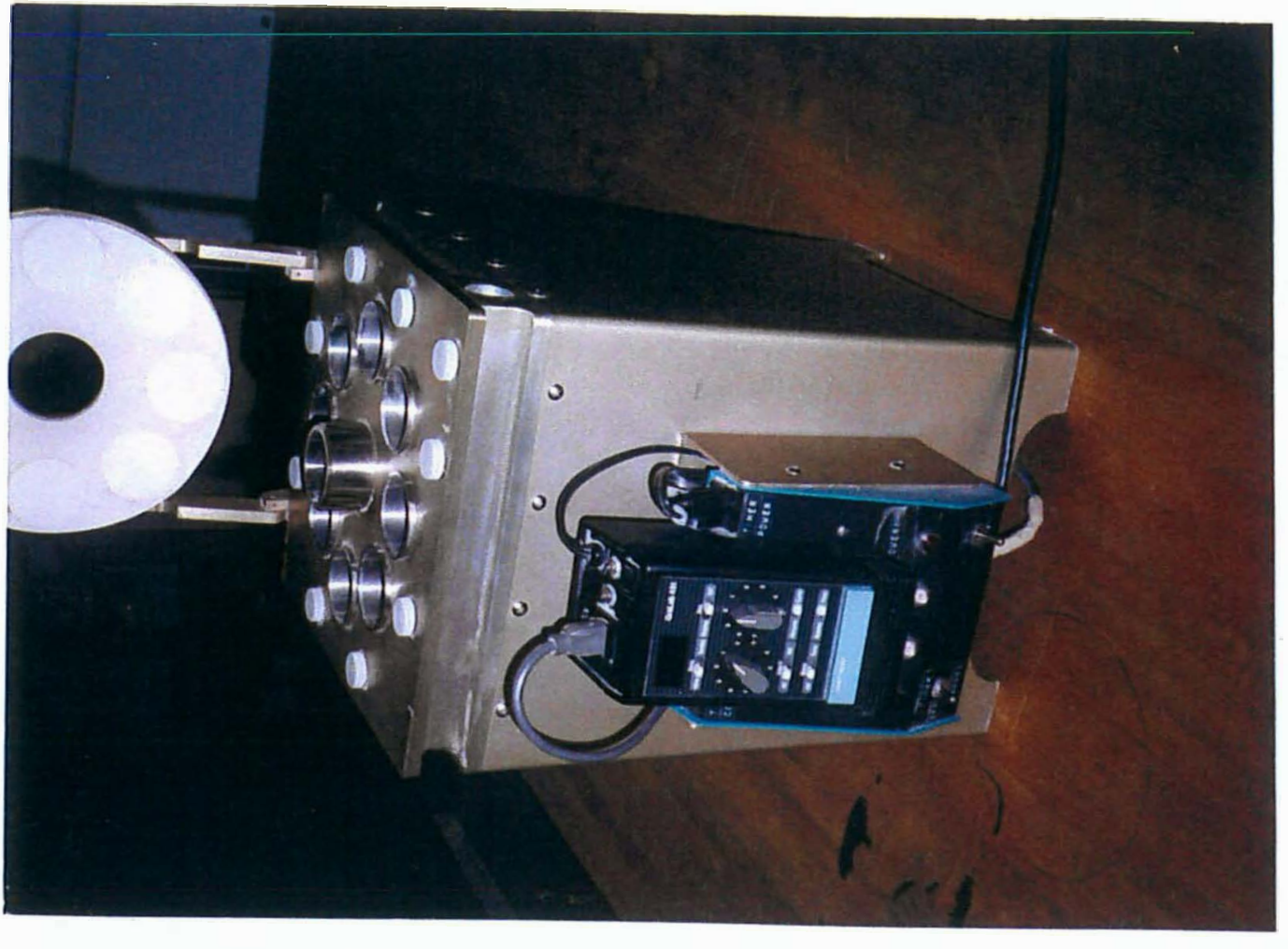



选

좀

记

토 음

뉵

氞

两

安

$H$.

กั

음

\&

쿄

을 吾

봄ํㅁ 


\section{REFERÊNCIAS BIBLIOGRÁFICAS}

ALBUS, W.L.; MORAGHAN, J.T. Responses of three early maturing corn hybrids to nitrogen fertilizer. Journal Production. Agriculture., v.8, n.4, p.581-584, 1995.

ANDRADE, A.G.de; HAAG, H.P.; OLIVEIRA, G.D. de; SARRUGE, J.R. Acumulação deferencial de nutrientes por cinco cultivares de milho (Zea mays L.) I. Acumulação de macronutrientes. Anais da E.S.A. "Luiz de Queiroz", v.32, p.115149, 1975.

ANDRADE, A.G.; HAAG, H.P.; OLIVEIRA, G.D. de; SARRUGE, J.R. Acumulação deferencial de nutrientes por cinco cultivares de milho (Zea mays L.) II. Acumulação de micronutrientes. Anais da E.S.A. "Luiz de Queiroz", v.32, p.151$171,1975$.

ARNOLD, J.M.; BAUMAN, L.F.; YCOCAK, H.S. Interrelations among protein, lysine, oil, certain mineral element concentrations, and physical kernel characteristics in two maize populations. Crop Science, v.17 p.421-425, 1977

BALKO, L.G.; RUSSEL, W.A. Response of maize inbred lines to $\mathrm{N}$ fertilizer. Agronomy Journal, v.72, p.723-728, 1980.

BANZIGER, M.; EDMEADES, G.O.; BECK, D.; BELLON, M. Breeding for drought and nitrogen stress tolerance in maize: From theory to practice. Mexico: CIMMYT, 2000. 68.p. 
BASSOI, L.H.; REICHARDT, K. Acúmulo de matéria seca e de nitrogênio em milho cultivado no período de inverno com aplicação de nitrogênio no solo e via água de irrigação. Pesquisa Agropecuária Brasileira, v.30, n.12, p.1361-1373, 1995.

BATAGLIA, O.C.; TEIXEIRA, J.P.F; FURLANI, A.M.C.; GALLO, J.R. Métodos de análise química de plantas. Campinas: IAC, 1978. 31 p. (Circular, 87).

BAUER, P.J.; CARTER, P.R. Effect of seeding date, plant density, moisture availability, and soil nitrogen fertility on maize kernel breakage susceptibility. Crop Science, v.26, p.1220- 1226, 1986.

BEAUCHAMP, E.G.;. KANNENBERG, L.W; HUNTER, R.B.. Nitrogen accumulation and translocation in corn genotypes following silking. Agronomy Journal, v.68, p.418-422, 1976.

BHATIA, C.R.; RABSON, R. Relationship of grain yield and nutritional quality. In: OLSON R.A.; FREY, K.I. (Ed.). Nutritional Quality of Cereal Grains: Genetics and Agronomic Management. Madison, WI: American Society of Agronomy, 1987. p.11-44,

BREMNER, J.M. Total nitrogen. In: BLACK, C.A.; EVANS, D.D.; WHITE, J.L.; ENSMINGER, L.E.; CLARCK, F.E. (Ed.) Methods of soil analysis. Madison, WI: American Society of Agronomy, v.2, p.1256-1286, 1965 (Agronomy, 9).

BRUNINI,O.; LISBÃO,R.S.; BERNARDI, J.B. Temperatura Base para Alface "Withe Boston", em um Sistema de Unidades Térmicas. Bragantia, v.35, p.214-219, 1976. 
CAMARGO, A.P.; CAMARGO, M.B.P. Teste de uma equação simples para estimativa da evapotranspiração potencial baseada na radiação solar extraterrestre e na temperatura do ar. In: CONGRESSO BRASILEIRO DE AGROMETEOROLOGIA, 3., Campinas, Anais. Campinas: Sociedade Brasileira de Agrometeorologia, 1983. p.229-244.

CAMARGO, A.P.; CAMARGO, M.B.P. Um revisão analítica da evapotranspiração potencial. Bragantia, v.59, p.125-137, 2000.

CAMPBELL, C.M. Influence of seed formation of corn on accumulation of vegetative dry matter and stalk strength. Crop Science, v.4, p.31-34, 1964.

CANTARElla, H.; DUARTE, A. P. Adubação do Milho Safrinha. In: SEMINÁRIO SOBRE A CUlTURA DO MILHO SAFRINHA. 3., Assis, 1995. Resumos. Campinas: IAC, CDV, 1995. p.21-27.

CARDWELL, V.B. Fifty years of Minnesota corn production: Sources of Yield Increase. Agronomy Journal, v.74, p.984-990, 1982.

CARLONE, M.R.; RUSSEL, W.A. Response to plant densities and nitrogen levels for four maize cultivar from different eras of breeding. Crop Science, v.27, p.465-470, 1987.

CERRATO, M.E.; BLACKMER, A.M. Relationships between grain nitrogen concentrations and the nitrogen status of corn. Agronomy Journal, v.82, p.44-749, 1990.

CHEVALIER, P.; SCHRADER, L.E. Genotype differences in nitrate absorption and partitioning of $\mathrm{N}$ among plant parts in maize. Crop Science, v.17, p.897-901, 1977. 
COELHO, A.M.; FRANÇA, G.E.; BAHIA, A.F.C.; GUEDES, G.A.A. Balanço de nitrogênio $\left({ }^{15} \mathrm{~N}\right)$ em um latossolo vermelho-escuro, sob vegetação de cerrado, cultivado com milho. Revista Brasileira de Ciência do Solo, v.15, p.187-193, 1991.

CROCOMO, O.J.; NEPTUNE, A.M.L. O ciclo do nitrogênio. O solo, v.54, n.1, p.9-72, 1962.

CROMWELL, G.L.; BITZER, M. J.; STAHLY, T.S.; JOHNSON, T.H. Effects of soil nitrogen fertility on the protein and lysine content and nutritional value of normal and opaque-2 corn. Journal of Animal Science v.57, p.1345-1351, 1983.

DOMMERGUES, Y.; MANGENOT, F. La rizosphère. Ecologie microbienne du sol. Paris: Masson, 1970. 760 p.

DOWSWELL, C.R.; PALIWAL, R.L.; CANTRELL, R.P. Maize in the third world. Westview Press, 1996. 268p.

DUARTE, A.P.; PARTERNIANI, M.E.A.G.Z. Cultivares de milho no Estado de São Paulo. Resultados das avaliações regionais IAC/CATI/Empresas - 1997/98. Campinas: Instituto Agronômico, 1998. 81 p. (Documentos, 62.)

DUARTE, A.P.; FREITAS, J.G.; PATERNIANI, M.E.A.G.Z.; CANTARELlA, H. Eficiência e resposta de genótipos de milho ao nitrogênio em cobertura.. In: CONGRESSO NACIONAL DE MILHO E SORGO, 23., resumos. Recife (PE), Associação Brasileirá de Milho e Sorgo, 1998. p.184.

DUDLEY, J.W.; LAMBERT, R.J.; DE LA ROCHE, I.A. Genetic analysis of crosses among corn strains divergently selected for percent oil and protein. Crop Science, v.7, p.111-117, 1977. 
DUVICK, D.N. Genetic contributions to yield gains of U.S. hybrid maize, 1930 to 1980 . In: Genetic contributions to yield gains of five major crop plants. Madison: ASA-CSSA, 1984. p.15-47.

DWYER, L.D.; ANDERSON, A.M.; DOUGLAS, W. S.; TOLLENAAR, M. Changes in maize hybrid photosynthetic response to leaf nitrogen, from pre-anthesis to grain fill. Agronomy Journal, v.87, p.1221-1225, 1995.

ELLINGS, A.; WHILE, J.W.; EDMEADES, G.O. Options for breeding for greater maize yields in the tropics. In: ITTERSUM, M.K. van ; GEIJN, S.C. van. (Ed.). Perspectives for agronomy - Adopting ecological principles and managing resource use . Amsterdam: Elsevier Science, 1997, p.155-168.

EMPRESA BRASILEIRA DE PESQUISA AGROPECUÁRIA. Sol-da-manhã NF. Sete Lagoas, s.d. 1v.

EPSTEIN, E. Nutrição mineral das plantas: princípios e perspectivas. São Paulo: EDUSP, 1975. 34lp.

FEIL, B.; THIRAPORN, R.; GEISLER, G.; STAMP, P. Genotype variaton in grain nutrient concentration in tropical maize grown during a rainy and a dry season. Agronomie, v.10, p.717-725, 1990.

FEIL, B.; THIRAPORN, R.; GEISLER, G.; STAMP, P. Yield, development and nutrient efficiency of temperate and tropical maize germoplasm in the tropical lowlands. II. Uptake and redistribution of nitrogen, phosphorus and potassium. Maydica, v.37, p.199-207, 1992.

FEIL, B.; THIRAPORN, R.; LAFITTE, H.R. Accumulation of nitrogen and phosphorus in the grain of tropical maize cultivars. Maydica, v.38, p.291-300, 1993. 
FREY, K.J.; BRIMHALL, B.; SPRAGUE, G.F. The effects of selection upon protein quality in the corn kernel. Agronomy Journal v.4, p.1399, 1949.

FRIEDRICH, J.W.; SCHRADER, L.E. N. Deprivation in maize during grain-filling. II. Remobilization of ${ }^{15} \mathrm{~N}$ and ${ }^{35} \mathrm{~S}$ and the relationship between $\mathrm{N}$ and $\mathrm{S}$ accumulation. Agronomy Journal., v.71, p.466-472, 1979

FRIESEN, D.K.; WADDINGTON, S.R.; DIALLO, A.; KANAMPIU, F. Breeding and agronomic approaches to managing abiotic stresses in maize. In: NATIONAL MAIZE WORKSHOP OF ETIOPIA, 2. Addis Ababa, 2001. Proceedings. México: CIMMYT, 2001.p.214-222.

FURLANI, P.R.; HIROCE, R.; BATAGLIA, O.C.; SILVA, W.J. Acúmulo de macronutrientes, de silício e de matéria seca por dois híbridos simples de milho. Bragantia, v.36, n.22, p.223-9, 1977.

GERLOFF, G.C. Plant efficiencies in the use of nitrogen, phosphorus and potassium. In: WORKSHOP ON PLANT ADAPTATION TO MINERAL STRESS IN PROBLEM SOILS, Ithaca, 1977. Proceedings. Ithaca: Cornell Univ. Agr. Exp. Sta., 1977. p.161-173.

HAGEMAN, R.H. Nitrate metabolism in roots and leaves. In: J. C. SHANNON et al. (Ed.). Regulation of carbon and nitrogen reduction and utilization in maize. Rockville, MD: Am. Soc. Physiology, 1986. p.105-116

HANWAY, J.J. Corn growth and composition in relation to soil fertility. I Growth of different plant parts and relation between leaf weight and grain yield. Agronomy Journal, v.54, p.145-148, 1962a. 
HANWAY, J.J. Corn growth and composition in relation to soil fertility. II Uptake of N, $\mathrm{P}$, and $\mathrm{K}$ and their distribution in different plant parts during the growing season. Agronomy Journal, v.54, p.217-222, 1962 b.

HARMSEN, G.W.; KOLENBRANDER, G.J. Soil inorganic nitrogen. In: Soil Nitrogen. Madison (Wisconsin): American Society of Agronomy, 1965. 615p. (Agronomy, 10)

HAY, R.E.; EATLEY, E.B.; DeTURK, E.E. Concentration and translocation of nitrogen compounds in the corn plant (Zea mays) during grain development. Plant Physiology, v.28, p.606-621, 1953.

Hill, L.D. Quality problems in exporting U.S. corn. Proceedings of the Annual Corn and Sorghum Research Conference, v.36 p.191-198. 1981

HIROCE, R.; FURLANI, A.M.C.; LIMA,M. Extração de nutrientes na colheita por populações e híbridos de milho. Campinas: Instituto Agronômico, 1989. 24p. (Boletim Científico, 17)

IAEA, 1970. Fertilizer management practices of maize: results of experiments with isotopes. Vienna. 78p. 1970. (Technical Report Series, 121).

JENKINSON, J.C. Chemical test for potentially available nitrogen in soil. Journal of the Science of Food and Agriculture, v.19, p.160-168, 1968.

JOHNSON, D.Q.; RUSSELL, W.A. Genetic variability and relationships of physical grain quality traits in the BSSS population of maize. Crop Science v.22 p.805-809 1982 , 
KARLEN, D. L.; SADLER, E.J.; CAMP, C.R. Dry matter, nitrogen, phosphurus, and potassium accumulation rates by corn on Norfolk Loamy Sand. Agronomy Journal, v.79, p.649-656, 1987.

KARLEN, D.L.; FLANNERY, R.L.; SADLER, E.J. Aerial accumulation and partitioning of nutrients by corn. Agronomy Journal, v.80, p.232-242, 1988.

KAUFFMANN, K.D.; DUDLEY, J.W. Selection indices for grain yield, percent protein, and kernel weight. Crop Science, v.19, p.583-588, 1979.

KNIEP, K.R.; MASON, S.C. Kernel breakage and density of normal and opaque-2 maize grain as influenced by irrigation and nitrogen. Crop Science, v.29, p.158$163,1989$.

LANG, A.L.; PENDLETON, J.W.; DUGAN, G.H. Influence of population and nitrogen levels on yield and protein and oil contents of nine corn hybrids. Agronomy Journal , v.48, p.284-289, 1956.

LEFORD, D.R.; RUSSELL, W.A. Evaluation of physical quality in BS17 and BS1(HS)Cl. Crop Science, v.25, p.421-425, 1985.

MACHADO,A.T.; MAGALHÃES, J.R. Melhoramento de milho para uso eficiente de nitrogênio sob condições de estresse. In: SIMPÓSIO INTERNACIONAL SOBRE ESTRESSE AMBIENTAL. Sete Lagoas, 1992. O milho em perspectiva. Sete Lagoas, México: EMBRAPA/CNPMS, CIMMYT/UNDP, 1995. p.321-343.

MACHADO, A.T.; MACHADO, C.T.T.; FURLANI, P.R. Avaliação e caracterização de variedades locais de milho para condições adversas de ambiente. In: SOARES, A.C.; MACHADO, A.T.; SILVA, B.M.; WEID, J.M.von der (Ed.). Milho Crioulo: conservação e uso da biodiversidade. Rio de Janeiro: AS-PTA, 1998a. p.151-178. 
MACHADO, A,T.; PEREIRA, M.B.; PEREIRA, M.E.; MACHADO, C.T.T.; MÉDICE, L.O. Avaliação de variedades locais e melhoradas de milho em diferentes regiões do Brasil. In: SOARES, A.C.; MACHADO, A.T.; SILVA, B.M.; WEID, J.M.von der (Ed.). Milho Crioulo: conservação e uso da biodiversidade. Rio de Janeiro: ASPTA,1998b. p.93-106.

MACHADO, A.T.; PATERNIANI, E. Avaliação de germoplasma de milho (Zea mays L.) com relação à eficiência e/ou fixação biológica do nitrogênio. In: CONGRESSO NACIONAL DE MILHO E SORGO,17., Resumos. Piracicaba: ESALQ, 1988. p.130.

MANOHARKUMAR, B.; GERSTENKORN, P.; ZWINGELBERG, H.; BOLLING, H. On some correlations between grain composition and physical characteristics to the dry milling performance for maize. Journal of Food Science and Technology, v.15 p.1-6, 1978

MILLER, B.S.;. HUGHES, J.W.; ROUSSER, R.; PONERANZ, R. Measuring the breakage susceptibility of shelled corn. Cereal Foods World, v.26 p.75-80, 1981

MOLL, R.H.; KAMPRATH, E.J. Effects os population density upon agronomic traits associated with genetic increases in yield of Zea mays L. Agronomy Journal, v.69, p.81-85, 1977.

MOLL, R.H.; E.J. KAMPRATH; W.A. JACKSON. Analysis and interpretation of factors which contribute to efficiency of nitrogen utilization. Agronomy Journal, v.74, p.562-564, 1982.

MOLL, R.H.; JACKOSON, W.A.; MIKKELSEN, R.L. Recurrent selection for maize grain yield: dry matter and nitrogen accumulation and partitioning changes. Crop Science, v.34, p.874-881, 1994. 
MORO, J.R.; NASPOLINI FILHO, V.; VIANNA, R.T.; GAMA, E.E.G. Introdução de novos germoplasmas de milho no Brasil. Pesquisa Agropecuária Brasileira, v.16, n.6, p.867-882, 1981.

NEPTUME, A.M.L. Efeito de diferentes épocas e modos de aplicação do nitrogênio na produção do milho, na quantidade de proteína, na eficiência do fertilizante e na diagnose foliar utilizando sulfato de amônio $-{ }^{15}$ N. Anais da ESALQ, v.34, n.1, p.515-539, 1977.

NEYRA, C.A.; PEREIRA, P.A., BALDANI, J.I.. Efficiency of nitrogen utilization by maize plant. In: Maize breeding and maize production. Belgrade, Yugoslavia: Europaize 88, 1988. p.219-231

OIKEH, S.O.; KLING, J.G.; OKORUWA, A.E. Nitrogen management effects on maize grain quality in the West Africa moist savanna. Crop Science,v.38 p.1056-1061, 1998.

OLSON, R.A.; FRANK, K.D.; DEIBERT, E.J.; DREIER, A.F.; SANDER, D.N.; JOHNSON, V.A. Impact of residual mineral $\mathrm{N}$ in soil on grain protein yields of winter wheat and corn. Agronomy Journal, v.68, p.769-772, 1976.

OSAKI, M. Comparison of productivity in relation to nitrogen nutrition; I. Leaf senescence and productivity in relation to nitrogen nutrition. Soil Science Plant Nutrition, v.41, n.3, p.439-450, 1995a.

OSAKI, M. Comparison of productivity in relation to nitrogen nutrition; II. Parameters determining between tropical and temperate maize. Soil Science Plant Nutrition, v.41, n.3, p.451-459, 1995 b. 
OSINAME, O. van GIJN, H.; VLEK, P.L.G. Effect of nitrification inhibitors on the fate and efficiency of nitrogenous fertilizers under simulated humid tropical conditions. Tropical Agriculture, v.60, n.3, p.211-217, 1983.

PALMER, A.F.E.; HEICHEL, G.H.; MUSGRAVE, R.B. Patterns of translocation, respiratory loss, and redistribution of ${ }^{14} \mathrm{C}$ in maize labeled after flowering. Crop Science, v.13, p.371-376, 1973.

PAN, W.L.; KAMPRATH, E.J.; MOLL, R.H.; JACKSON, W.A. Prolificacy in corn: its effects on nitrate and ammonium uptake and utilization. Soil Science Society American Journal, v.48, p.1101-1106, 1984.

PAN. W.L.; CAMBERATO, J.J.; MOLL, R.H., KAMPRATH, E.J.; JACKSON, W.A. Altering source-sink relationships in prolific maize hybrids: Consequences for nitrogen uptake and remobilization. Crop Science, v.35, p.836-845, 1995.

PATERNIANI, E. Maize breeding in the tropics. Plant Science, v.9, n.2, p.125-154, 1990.

PAULSEN, M.R.; HILL, L.D. Corn quality factors affecting dry milling performance. Journal of Agricultural Engineering Research, v.31, p.255-263, 1985.

PAULSEN, M.R.; HILL, L.D.; WHITE, D.G.; SPRAGUE, G.F. Breakage susceptibility of corn-belt genotypes. Transactions of the American Society of Agricultural Engineers, v.32, p.1007-1014, 1983.

PEPLINSKI, A.J.; PAULSEN, M.R.; ANDERSON, R.A.; KWOLEK, W.F. Physical, chemical, and dry milling characteristics of cor hybrids from various genotypes. Cereal Chemistry, v.66, p.117-120, 1989. 
POLLMER, W.G.; EBERHARD, D.; KLEIN, D.; DHILLON, B.S. Genetic control of nitrogen uptake and translocation in maize. Crop Science, v.19 p.82-86, 1979.

REED, A.J.; BELOW,F.E.; HAGEMAN, R. Grain protein accumulation and the relationship between leaf nitrate reductase and protease activities during grain development in maize. Plant Physiology, v.66, p.164-170, 1980.

REICHARDT, K.; LIBARDI, P.L.; VICTÓRIA, R.L.; VIÉGAS, G.P. Dinâmica do nitrogênio num solo cultivado com milho. Revista Brasileira de Ciência do Solo, v.3, p.17-20, 1979.

REICHART, R.D.; TYLER, R.T.; YORK, A.E.; SCHWAB, D.J.; , TATARYNOVICH, J.E. ;. MWASARU, M.A.. Description of a production model of the tangential abrasive dehulling device and its application to breeder's samples. Cereal Chemistry, v.63, p.210-207, 1986

RENDIG, V.V.; BROADBENT, F.E. Proteins and amino acids in grain of maize grown with various levels of N. Agronomy Journal, v.71 p.509-512, 1979

RUSSEL, W.A. Agronomic performance of maize cultivars representing different eras of breeding. Maydica, v.29, p.375-390, 1984.

SÁ, J.C.M. Manejo da fertilidade do solo no plantio direto. Castro, Fundação ABC, 1993. $96 \mathrm{p}$.

SÁ, J. C. M. Nitrogênio: Transformações no solo, mobilização e imobilização. In: CURSO SOBRE MANEJO DO SOLO NO SISTEMA PLANTIO DIRETO. Castro, 1995. Anais. Castro: Fundação ABC, 1995a. p.206-212, 
SÁ, J.C.M. Nitrogênio: Influência da rotação de culturas e resposta da cultura de milho em solos sob plantio direto. In: CURSO SOBRE MANEJO DO SOLO NO SISTEMA PLANTIO DIRETO. Castro, 1995. Anais. Castro: Fundação ABC, 1995b, p.213-227.

SAS INSTITUTE. SAS Property Software: Version 6.03. Cary, N.C., 1990.

SAYRE, J.D. Mineral accumulation in corn. Plant Physiology, v.23, n.3, p.267-281, 1948.

SHUMWAY, C.R.; COTHREN, J.T.; SERNA-SALDIVAR, S.O. ; ROONEY, L.W. Planting date and moisture effects on yield, quality and alkaline-processing characteristics of food-grade maize. Agronomy Journal, v. 32 p. 1265-1269, 1992

SIDDIQI, M.Y.; GLASS, A.D.M. Utilization index: a modified approach to the estimations and comparison of nutrient utilization efficiency in plants. Plant Nutrition, v.4, n.3, p.289-302, 1981.

THIRAPORN, R. GEISLER, G.; STAMP, P. Yield and relationships among yield components and $\mathrm{N}$-and $\mathrm{P}$-related traits in maize genotypes under tropical conditions. Journal Agronomy \& Crop Science, v. 152, p. 460-468, 1983.

THIRAPORN, R.; FEIL, B.; STAMP, P. Effect of nitrogen fertilization on grain yield and accumulation of nitrogen, phosphorus and potassium in the grains of tropical maize. Journal Agronomy \& Crop Science, v.169, p.9-16, 1992.

THOMPSON, L.M. Climatic change, weather variability and corn production. Agronomy Journal, v.78, p.649-653, 1986. 
THOMPSON, R.A.; FOSTER, G.H.. Stress cracks and breakage in artificially dried corn. Washington, D.C: USDA, Agricultural Marketing Service,. 1963. (Marketing Research Report, 631)

THORNTHWAITE, C.W., MATHER, J.R. The water balance. Centerton, N.J.: Drexel Institute of Technology - Laboratory of Climatology, 1955. 104p. (Publications in Climatology, v.8, n.1)

TOLLENAAR, M. Genetic improvement in grain yield of commercial maize hybrids grown in Ontario from 1959 to 1988. Crop Science, v.29, p.1365-1371, 1989

TOLLENAAR, M. Physiological basis of genetic improvement of maize hybrids in Ontario from 1959 to 1988. Crop Science, v.31 p.119-124, 1991.

TSAI, C.Y.; WARREN, H.L.; HUBER, D.M.; BRESSAN, R.A. Interactions between the kernel $\mathrm{N}$ sink, grain yield and protein nutritional quality of maize. Journal of the Science of Food and Agriculture, v.34 p.255-263, 1983

TSAI C.Y; DWEIKAT, I.; HUBER, D.M.; WARREN H.L. Interrelationship of nitrogen nutrition with maize (Zea mays) grain yield, nitrogen use efficiency and grain quality. Journal of the Science of Food and Agriculture, v.58, p.1-8, 1992

TSUNECHIRO, A. Aspectos econômicos da cultura do milho no Estado de São Paulo. In: DUARTE, A.P.; PATERNIANI, M.E.A.G.Z. Cultivares de milho no Estado de São Paulo. Resultados das avaliações regionais IAC/CATL/empresas - 1996/97. Campinas: Instituto Agronômico, 1997. 1-8p. (IAC. Documentos, 58.)

ULLOA, A. M. C. Absorção, translocação e eficiência de utilização do nitrogênio fertilizante $\mathrm{CO}\left({ }^{15} \mathrm{NH}_{2}\right)_{2}$ por dois híbridos de milho (Zea mays L.). Piracicaba, 1981. 78p. Dissertação (Mestrado), ESALQ, USP. 
VASCONCELLOS, C.A.; BARBOSA, J.V.A.; SANTOS, H.L. dos ; FRANÇA, G.E. de. Acumulação de massa seca e de nutrientes por duas cultivares de milho com e sem irrigação suplementar. Pesquisa Agropecuária Brasileira., v.18, n.8, p.887-901, 1983.

VYN, T.J.; MOES, J. Breakage susceptibility of corn kernels in relation to crop management under long growing season conditions. Agronomy Journal, v.80, p.915-920, 1988.

VYN, T.J.; TOLLENAAR, M. Changes in chemical and physical quality parameters of maize grain during three decades of yield improvement. Field Crops Research, v.59 p.135-140, 1998.

WATSON, S.A. Measurement and maintenance of quality. In: WATSON, S.A.; RAMSTAD, P.E (Ed.). Corn: Chemistry and Technology. St. Paul, MN: American Association of Cereal Chemists, 1987, p.125-183.

WETSELAAR, R.; FARQUHAR, G.D. Nitrogen losses from tops of plants. Advances in agronomy, v.33, p.263-302, 1980.

WU, Y.V.; BERGQUIST R.R. Relation of corn density to yields of dry milling products. Cereal Chemistry, v.68, p.542-544, 1991. 